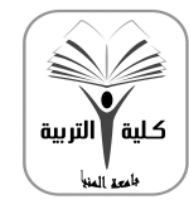

$$
\text { مجالة البجث في التزبية وعلم النفس }
$$

كلية مُعتمدة من الميئة القومية لضمان جودة التمليم

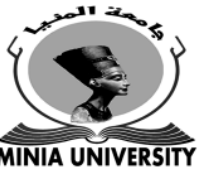

روئية هقترحة لتطوير الإشراف على الرسائل العلمية بالجامعات المصرية في ضوء خبرات بعض الجاهعات الأجنبية "دراسة هقارنة" لئه إعداد

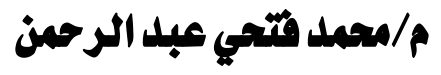

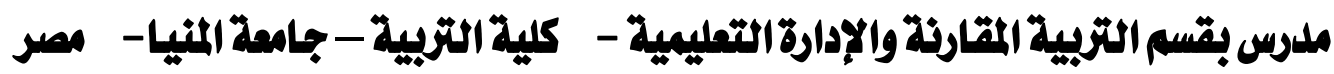

هدف البحث إلى تقليه رؤلة مقترحة لتطوير الإثراف على الرسائل العلمية ( الماجستير والدكتوراه ) بالجامعات المصرية في ضوء واقعه ووضعه الراهن، ونتائج التحليل المقارن لخبرات ثلاث جامعات أجنبية متميزة ورائدة في مجال البحث العلمي من ثلاث قارات مختلفة، وهي( جامعة أكسفورد بانجلترا في قارة أوربا، جامعة نيو سوث ويلز بسيلدي أستراليا، جامعة أوكلاند بنيوزبلندا في آسيا )، واستخلم البحث المنهج المقارن، وعلى ضوء خطواته تناول البحث طبيعة الإثراف على الرسائل العلمية وأبعاده وأسسه النظرية والفكرية، وتشخيص وتحليل واقعه ووضعه الراهن بـالجامعات المصرية من منظور التشريعات والسياسات والقوانين واللوائح المنظمة له والدراسات والبحوث السابقة والأدبيات التربوية المعاصرة، ثم وصف أهم ملاح خبرات الجامعات الأجنبية الثلاثة المختارة في مجال الإثراف العلمي، ثم تحليل مقارن لأوجه الشبه والاختلاف بينها وبين الجامعات المصرية في هذا المجال؛ لاستخلاص أوجه الاستفادة من تلك الخبرات، ومن ثم بناء الرؤية المقتزحة وصياغة فلسفتها وأهدافها ومحاورها وأبعادها (إدارةوتثظيه الإشراف العلمي، ومعايير اختيار المشرفين وتشكيل لجان الإشراف، وأدوارومسئوليات الأستاذ الشرف والطالب الباحث، وضوابط العلاقة الإثرافية بينهما، والتتمية المهنية لأعضاء هيئة التدريس في مجال الإثراف العلمي )، ووضع آليات وتوصيات قد تسهم في تنفيذ الرؤية المقترحة وأبعادها، واختُته البحث بمجموعة من الدراسات والبحوث المستقبلية المقتر حة في مجال الإثراف على الرسائل العلمية. الكلمات المفتاحية ؛ تطوير، الإثراف العلمي، الرسائل العلمية ( الماجستير الدكتوراه ). 


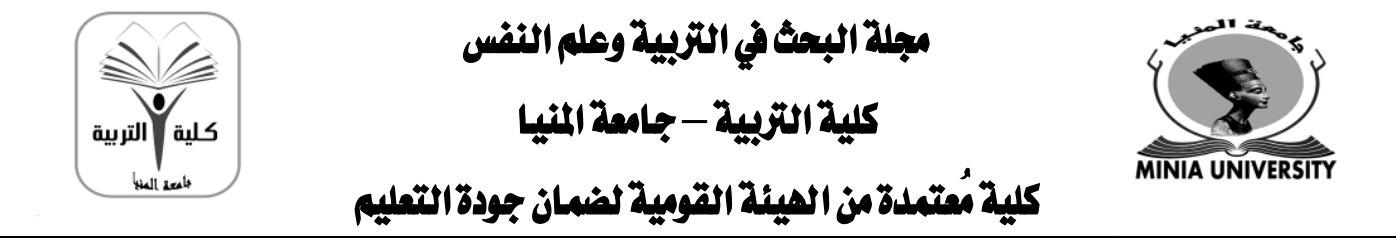

Abstact

\section{A Proposed Vision for Developing Supervision of Scientific Researches at Egyptian Universities in Light of Some Foreign Universities' \\ Experiences "A Comparative Study"}

\section{Muhammad Fathy Abdel Rahman}

A Lecturer at Department of Comparative Education and Educational Administration, Faculty of Education - Minia University, Egept.

The present research aimed to provide a proposed vision for developing supervision of scientific Researches (Master Theses and Doctoral Dissertations) at Egyptian universities in light of its current status andthe results of a comparative analysis of the experiences of three distinguished foreign universities in the field of scientific research from three different continents, namely, Oxford University in Europe, University of New South Wales, in Australia, University of Auckland, New Zealand in Asia. The comparative approach was utilized and in light of its steps, the research tackled the nature of supervisionof scientific reseaches, its dimensions, theoretical and intellectual foundations, and the diagnosis and analysis of its current status at the Egyptian universities from the perspective of legislation and laws and contemporary educational literature. The researchthen described the most important supervision experiences of the selectedthree foreign universities in the field of scientific supervision, and then it provided a comparative analysis of the similarities and differences between them and the Egyptian universities to draw the benefits of these experiences and then build the proposed vision, formulate its philosophy, objectives,dimensions(management and organization of scientific supervision,criteriaof supervisorsselectionand the formation of supervisory committees, the roles and responsibilities of supervisor and researcher, controls of supervisory relationship between them, and professional development of faculty members in the field of scientific supervision), and develop mechanisms and recommendations that may

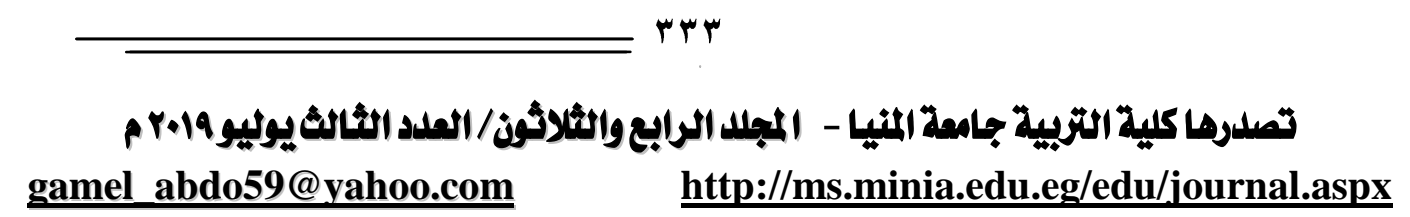




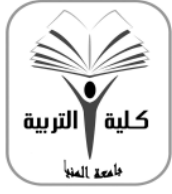

\section{مجلة البعث في التزبية وعلم النفس \\ كلية التربية - جامعة المنيا}

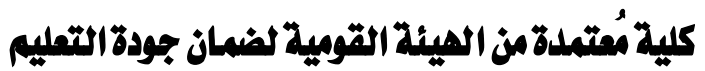

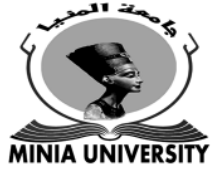

contribute to the implementation of the proposed vision and its dimension. The research finally concluded with a set of suggestions forfurther research in the area of the supervision of scientific reseaches.

Keywords: Development, Scientific Supervision, Scientific Researches (Master Theses and Doctoral Dissertations).

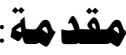

يُعد البحث العلمي ركيزة أساسية لتقدم المجتمعـاتو تحقيق التنمية الشـاملة، فنهضة اللدول

ورقيها مرهون بجودة بحثها العلمي، وملدى توافر مستلزماته وإمكانـات تطويره، والاهتمـام بـالبـاحثين على اختلاف مجالاتهم ومستوياتهم ودرجاتهم العلمية، والبحث العلمي بالجامعات على مستوى الدراسات العليا له أهية كبيرة في تطوير المجتمع بجوانبه ونظمه المختلفة ( التعليمية، والاقتصادية، والثقافية، والسياسية، ... إلخ ) من خلال مـا ينتجه الطلاب البـاحثون مع مشرفيهم من رسيائل علميلة ( ماجستير ودكتوراه ) وبحوث تتضمن معرفة نظريـة وتطبيقيـة تسهم في خدمة المجتمع وتنميته وححل مشكلاته ومعا لجة قضاياه، وتعمل على تقدمه ورفعته في المجالات المجتمعية والتنموية كافة.

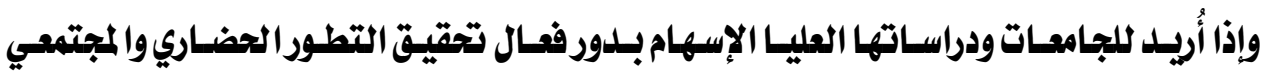
والتنمية الشاملة التي أصبحت مرهونة بتقدم الرسائل البحوث العلمية وتطبيقاتها، فمن الضروري تطوير نظام الإثراف العلمي المسئول عن إعلاد الكفاءات البحثية، والرسائل والبحوث العلمية ليصبح أكثر فاعلية

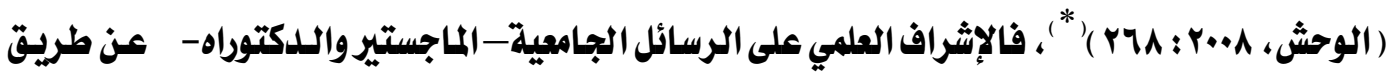
تلدريب الطلاب على ههارات البحث العلمي يمثل أهم فعاليـات تحقيق أهلداف البحث العلمي على مستوى

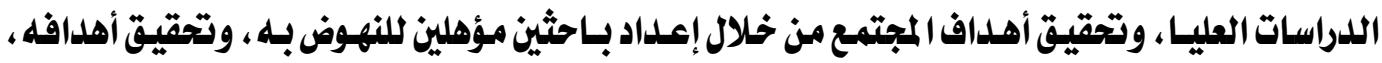

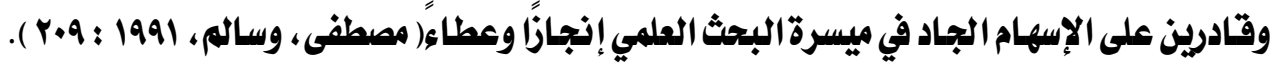

(*) اتبع البحث نظام توثيق American Psychological Assoctiation (APA:6) الخاص بالجمعية

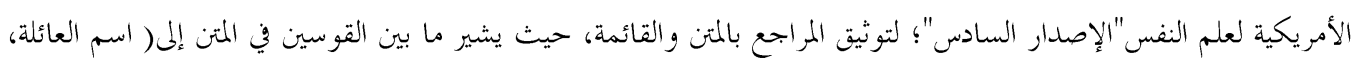

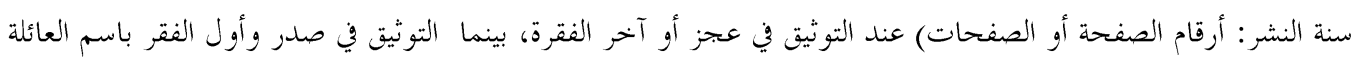
(سنة النشر: أرقام الصفحة أو الصفحات). أصنات الصفحات) عندات rrs

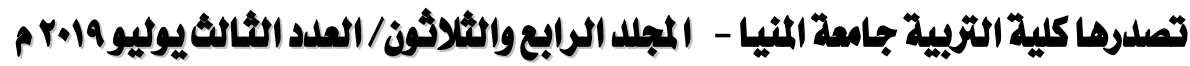
gamel_abdo59@yahoo.com

http://ms.minia.edu.eg/edu/journal.aspx 
وتتوقف جـودة الرسيائل العلميلة التي يُعدها الطلاب البـاحثوز بمر حلتي الماجستير والدكتوراه

بشكل أساسي على مستوى جودة العملية الإشرافية، وكفاءة الإثراف ودور المشرف؛ للذا يتفق المهتمون بالبحث العلمي والتربوي على أهمية دور المشرفين على الرسائل العلمية، وضـرورة قيـامهم بـأدوارهم ومسئولياتهم في توجيه وإرشاد الطلاب البـاحثين ومساعلدتهم في إنجاز تلك الرسيائل على الوجه المـأمول، إلا أن هذا الـدور للمشرف العلمي قدل يفقد أهميته ، ويؤثر سلبًا على شخصية الطالب الباحث والمؤسسة البحثية والمجتمع إذا لم يُنفذ بـالشكل المأمول؛ حيث يترتب عليه مخرجات بحثية ضعيفة؛ مما يُضعف ثقة المجتمع ومؤسسـاته في نتائج تلك الرسائل والبحوث، ومن ثم فإن تحقيق جودة الإشراف ومخرجاته البحثية مسئولية تشـاركية بـين الطالب الباحث والأستاذ المشرف، وتعتمل بشكل رئيس على التواصل الجيـل بينهمـا، والاتفـاق على معايير

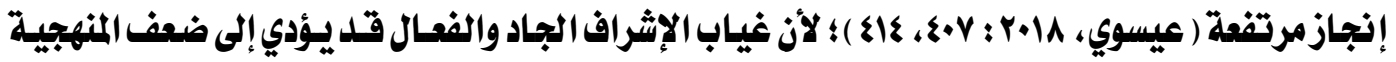
العلمية السليمة في الرسالة، بحيث لا يبقى بعد ذلك إلا النقل والاقتباس( السكران، 17 بr ؛ •r ). وذلك مع الأخذ في الاعتبـار أن جودة الإثراف وحدها - من وجهة نظر الباحث- لن تحقق الجودة المطلوبـة للرسسائل والبحوث العلمية إلا بوجود بـاحث متمكن لله صفات مهيزة، ويتم اختيـاره واتتقائه في ضوي معايير علمية سليمة، بـالإضافة إلى بيئة بجثية محفزة ومنـاخ علمي يشجع على الإبـلـاع، وغيرهـا من عوامل النجـاح في البحث العلمي.

وعلى الـرغم من أهمية ثكامل العوامل السـابقة، فلدوروخبرات المشرفين مهيم في إنجاز الرسبائل

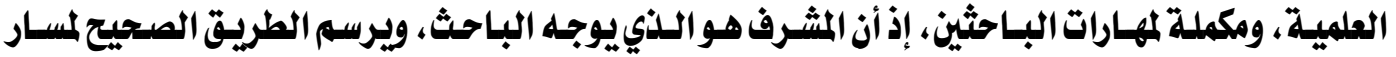
بحثه ، وإن كان من المسلم بله- ويتفق الباحث مع ذلك- أن البحث من اختصـاص الباحث، هو الـذي يملك ناصيته، ويلافع عنه أمام المشرف أوثًا، ثم أمام الجنة الامتحسان والمناقشئة ثانيـا ، إلا أن ثكامل الأدوار بـيز طـرفي الإثـراف ( الأستاذ والباحث) )واضـح، فالباحث بغير مشـرف كالسـفينة التائهـة في عـرض البحر، تتلاطمها الأمواج يمنة ويسرة، وخاصة في ظل تدفق المعلومـات والمعرفة غير النهائي( علي ومحمد، 10 ). فالإثراف العلمي من الأهمية بمكان ؛ حيث يحتـاج الباحث لمشرف يثق فيه ، ويشـاركه في التفكير،

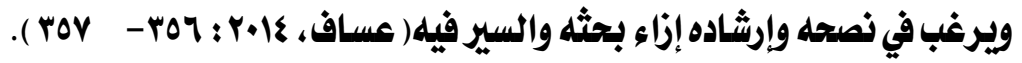
ودور عضو هيئة التدريس في عملية الإشراف العلمي دورشليد الأهمية والتعقيد، فقي ظل التطور rro

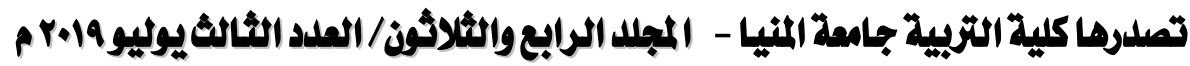
gamel_abdo59@yahoo.com

http://ms.minia.edu.eg/edu/journal.aspx 
المعرفي والتكنولوجي المتلاحق، والأعداد المتزايلة لطلاب اللدراسات العليـا بمر حلتي الماجستيروالدكتوراه، والضفوط على المشرفين لإتتـاج بحوث ورسـائل علميـة عاليـة الجـودة، وتخريج بـاحثين متميزيزين، أصبح الإثراف على الرسائل العلمية مهمة أكثر تعقيداً (682-680 2007: Lee) ؛ ومن ثم فإنه ينبغي لعضو هيئة التدريس المشرف أن يكوز على وعي بـأدواره ومهامه ومسئولياته في عملية الإشراف، وكيفية التعامل مع الطاب بطبائعهم المختلفة، كمـا ينبفي أنيكون على وعي بطبيعة الإثراف العلمي وخصائصه ، والقواعد التي تحكمه ، والعوامل والمتفيرات المختلفة التي تؤثر فيه، ومن هنـا تأتي أهمية التنمية المهنيلة لأعضساء

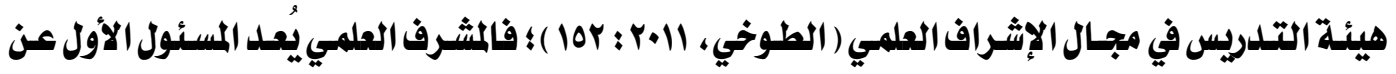
تشكيل عقلية الباحث وتنميـة مهاراته وقدراته على التفكير الإبـداعي والابتكـاري والناقدل في اختيـار الموضوعات البحثية، وطرائق ومنهجيات معالجتها وتحليل نتائجها وتفسيرها ؛ للخروج بنتائج سليمة وعمل

\section{علمي رصين ذي قيمة علمية نظرية وتطبيقية.}

وعلى الرغم من أهمية الإثراف على الرسيائل العلمية ودوره في تجويـل البحث العلمي على مستوى

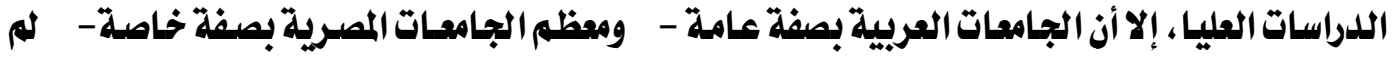
تُعْط هذا الموضوع حقه من الاهتمام الكافي والدراسة العلمية التحليلية لجوانبهـ ( نظريـا وميـانيًا )، في حسين انصب اهتمام الباحثين في الفالب على تقييم أداء الأستاذ الجامعي في مجال التدربس والإتتاج البحثي ( أبر

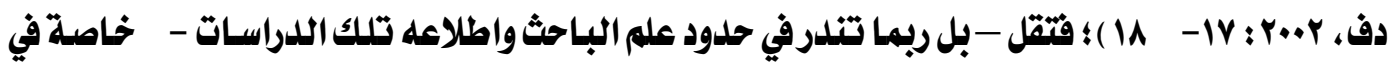
البيئة المصرية- التي تقوم بتحليل عملية الإثراف وتوضيح جوانبها، والعوامل المؤثرة فيها، وتحليـل أدوار المشرف والباحث ومسئوليـاتهما، ومهـارات المشـرف في تخطيط عمليـة الإثـراف ناهيك عن تنفيـذها وتقويهها ؛ الأمر الذي ترتب عليه بعض الآثار السلبية على جودة الإثراف العلمي طرفيه ( الأستاذ المشرف

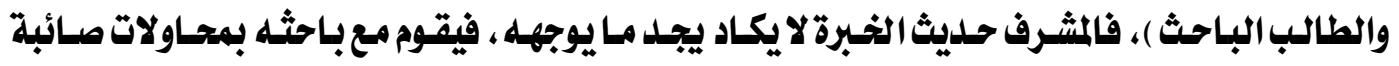
وأحيانًا خائبة، ويظل الأمر متروكًا للمحاولة والخطأ، فتقل فاعلية الإثراف، ومن ثم فاعلية البحث أو الرسالة العلمية المنتجة، ولصبح بعض الطلاب الباحثين عرضة للفشل في دراسـاتهم، أو الوصول من خلادهـا إلى تعميمات خاطئة يظل المشرف العلمي مسئولًا عنها بلدرجة كبيرة ( مصطفى، وسالم، 1991 ؛ III ). وعلى النقيض، في جامعات الـدول المتقدمة ومنها : جامعة أكسفورد بـانجلترا، وجامعة نيوسوثي rru

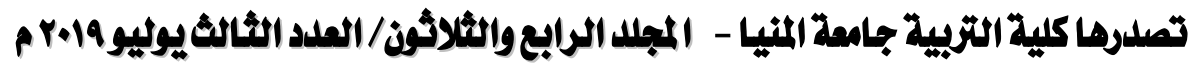
gamel_abdo59@yahoo.com

http://ms.minia.edu.eg/edu/journal.aspx 
ويلز بـأستراليا، وجامعة أوكلاند بنيوزيلندا- على سبيل المثال لا الحصر - يحظى الإشراف على البحوث والرسائل العلمية بـاهتمام كبير من قبل الباحثين كمجال وموضوع بحثي، وبـأهمية قصوى من جانب إدارة تلك الجامعـات والمسئوليز والمختصـين بـالبحث العلمي على مستوى الدراسـات العليـا كأحسل أهم العوامل إعـلـاد بـاحثين أكْفاء وتجويد الرسائل والأطروحات العلمية ؛ حيث تضع هـذه الجامعـات سياسـات وقواعلد واضحة "Supervision of Codes Practice and Guidelines, ومحدةة لممارسة الإثراف العلمي" Supervision Policy and Procedures " الإثراف تضمن حرية الباحث ورغبته في اختيار مشرفه والعكس، وتحلد أدوارومسئوليات واضحة للمشرف والباحث خلال عملية الإشراف من أجل إنجاز الرسالة، وتضع الضوابط والقواعد المنظمة للعلاقة الإثرافية بينهما، كما تقدم برامج ودورات تدربيية للتنمية المهنية لأعضاء هيئة التـلدريس في مجال الإثراف العلمي كثرط أساسي للتعيين في لجسان الإثـراف في بعض الجامعـات وخاصة للمشرفين المبتـلئين ، كمـا تقوم هـده

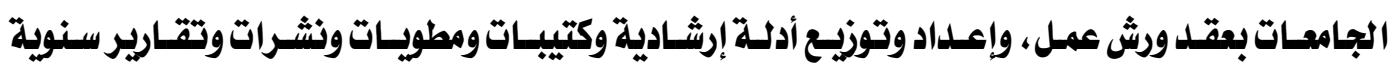
ومجلات، وتصميه مواقع إكترونية على الإنترنت وشبكات التواصل الاجتماعي تقلم معلومات حول الإثراف

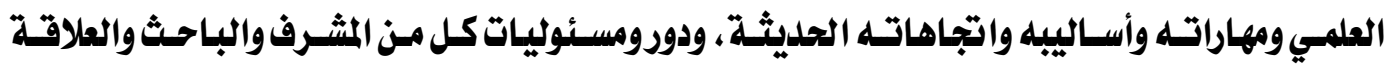
الإثـرافية بينهمـا ؛ إيعانًا منهـا بـأهيـة الإثـراف العلمي ودوره في نجـاح العمليـة البحثيـة على مسـتوى الدراسات العليـ(Kee,2007:680-682) ، (Kiley,2011,:585) ، (Official university) .website, Oxford, New South Wales, Auckland, 2019)

ولعل ضعف الإثراف العلمي على الباحثين ورسائلهم العلمية، نتيجة غياب أو قصور معايير اختيسار الشرفين وقواعد تشكيل لجان الإشراف العلمي، وقلة فهم بعض أعضـاي هيئة التـدريس المشرفيز -وخاصة الجدد المبتدئين- لطبيعة عملية الإشراف العلمي وأبعاده ومهاراته وأساليبه واتجاهاته الحليثة، وكيفية

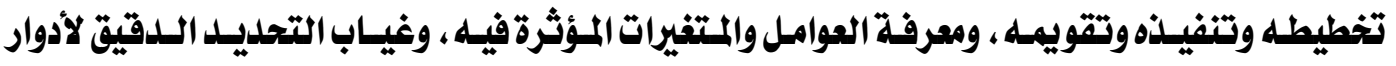
ومسئوليات المشرف والباحث في إنجـاز الرسـالة، وضعف أو غيـاب الضـوابط المنظمة للعلاقة الإثـرافية بينهما، وقلة الاهتمام بالتنمية المهنيـة لأعضساء هيئة التلدريس في مجـال الإثراف العلمي، كل ذلك ربمـا يمثل أسباب أساسية لتدني مستوى كثير من الرسائل العلمية، وبعدها بلدرجة كبيرة عن معسيير جودة البحث rrv

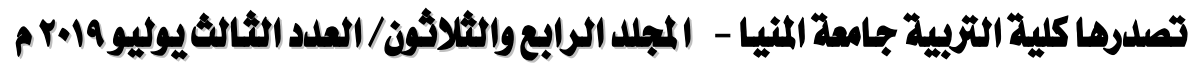
gamel_abdo59@yahoo.com

http://ms.minia.edu.eg/edu/journal.aspx 
العلمي محليًا، ناهيك عن معايِير الجودة العالية، وذلك دوذ إلقاء اللوم على المشرف وحلده كطرف مسئول، ولكن ربما كان السبب في ذلك الطرف الأصيل والرئيس صاحب الرسالة والمسئول الأول عنها وهو "الباحث" ؛ لنقص مهاراته وقدراته البحثية النابع من ضعف معايير اختياره وعملية إعداده في مراحل التعليم المختلفة، ويمتل ضعف هذا الإعلداد وبرامجه حتى مرحلة الدراسات العليا، ناهيك عز العوامل الأخرى من بيئة ومنساخ بحثي، وإمكانات ومكتبات ...إلخ مما يتطلبه إعداد بحث أو رسالة علمية جيلدة. وانطالاقًا ممـا سبق، وفي ضوي أهمية عملية الإثراف العلمي، وخطورة القصور في فهم طبيعتها وتخطيط وتنفيذ وتقوبم ممارساتها، والمخاطر والآثار السلبية لذلك على الباحث والمشرف والبحث العلمي وا لمجتمع بـأكمله، وفي ظل قلة الدراسات والكتابات المصرية في هذا المجال، يتجه البحث الحسالي إلى دراسة الإثـراف على الرسـائل العلميـة تنظيرًا لطبيعته وأبعـاده، وتحليلًا لواقعـه ووضعه الـراهن بـالجامعـات المصرية، ومطالعة نظم الإثراف العلمي ببعض الجامعات الأجنبية المتقدمة، ومقارنتها بنظـام الإثراف

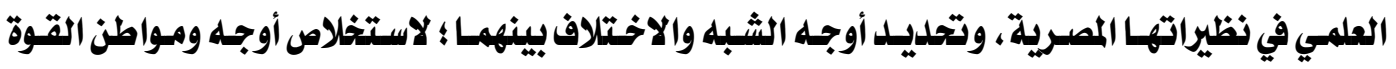
الاستفادة التي يمكن الارتكاز عليها في بلورةوصياغة رؤية تطويرية مقترحة للإشراف على الرسائل العلمية بالجامعات المصرية. هشكلة البحث وأسئلته: على الرغم من أهمية الإثراف على الرسائل العلمية بـالجامعات المصرية ، ودوره المحوري في إعلداد تلـك الرسبـائل ومسـتوى جودتهـا، إلا أن الواقـع والوضـع الـراهن لنظــام الإثــراف على الرســائل العلميـة بـالجـامعات المصرية يعـاني كثيرًا من المشكلات وأوجـه القصـوروالسلبيات على مستوى إدارته وتنظيمهـ ، ومعايير اختيار المثرفين وتثكيل اللجان الإثرافية، وتحليل أدوارومسئوليات المشرفين والطلاب، وتنظيي العلاقة الإثرافية بينهما، والتنمية المهنية لأعضاي هيئة التدريس في مجال الإثراف على الرسائل العلمية، وتعلد وتتنوع المصادر التي ثثبت وتعضلد ما يعانيه الإشراف العلمي وجوانبه المختلفة بـالجامعات المصرية من مشكلات، وذلك على النحو الآتي:

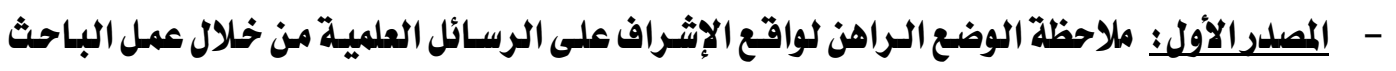

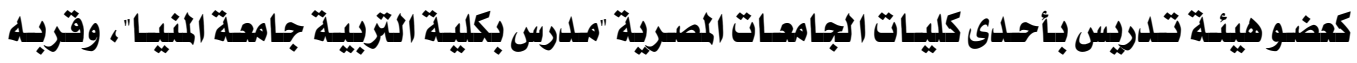
rrA

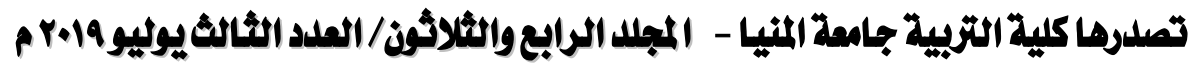
gamel_abdo59@yahoo.com

http://ms.minia.edu.eg/edu/journal.aspx 
معايشته لواقع العملية البحثية والإثرافية على الطلاب الباحثين في مرحلتي الماجستير والدكتوراه من أعضاء الهيئة المعاونة ومن خارجها، وتجربته الشخصية كباحث مر بهاتين المر حلتين يُضـاف إليها تجـارب التزملاء في مختلف التخصصـات والكليـات الأخرى بجامعة المنيـا وغيرهـا ممن يتواصل معهـم الباحث، وتجربة الباحث كمشرف مبتدئ على بعض طلاب الماجستير، فمن خلال تلك الملاحظة والتجارب والمعايشة للواقع تبين للبـاحث كثير من المشكلات وأوجهه القصـور التي يعـاني منهـا نظـام الإثراف على الرسائل العلمية بهعظم الجامعات المصرية، منها : غياب أو قلة وجسود معايير واضحة ومحددة لاختيـار المشرفين وتشكيل اللجـان الإثـرافية، وغيـاب التحليـد الواضح والـدقيق لأدوارومسئوليات المشرف والطالب في إنجاز الرسالة، وقلة وجود ضوابط منظمة للعلاقة الإثرافية بينها، وقلة مصسادر الدعم وأنشطة وبـرامج التنميـة المهنية في مجـال الإثـراف العلمي وخاصة للمشرفين المبتدئين، ويمثل هـذا المصدربلداية إحساس وشعور الباحث بمشكلة البحث، ودافضًا مهمًا للدراستها وبحثها. - المصلدر الثاني : وللتأكلد من أهمية دراسة هذا الموضـوع كقضية ومشكلة بحثيلة ملحة موجـودة بـالواقع الفعلي، ودفمًا للذاتية التي قد تشوب المصلدر الأول حول شعور الباحث وإحساسه بالمشكلة ووجودها من

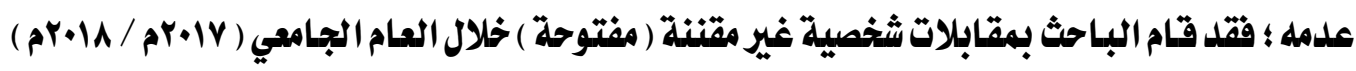
حول واقع الإثراف العلمي بـالجامعات المصرية ودوره في تجويـد الرسـائل العلميلة من وجهة نظـر بعض أعضاء هيئة التدريس المشرفين والطلاب البـاحثين بمرحلتي الماجستير والدكتوراه ببعض الجامعات المصرية وكلياتها، وذلك أثنـاء حضور الباحث لبعض المؤتقرات والنـلوات العلمية ببعض والجـامعات وكليات التربية وبعض الجمعيات العلمية، وقد أظهرت تتائج هذه المقابلات وجـود أوجهه ضعف وقصور في عمليـة الإثـراف على الرسـائل العلميـة بـالجامعـات المصـرية على مسـتوى معـايير اختيـار المشـرفيز وقواعـد تشكيل لجـان الإثـراف العلمي، ومـدى معرفة المشـرف والطالب بـأدواره ومسئولياته خـلال الإثـراف، وتدهور مسـتوى العلاقة الإثـرافية ( المشـرف/ الباحث ) في كثير مـن الحسالات لقلة وجـود الضوابط والقواعد الحاكمة، وقتلة برامج وأنشطة التنمية المهنية لأعضاء هيئة التلدريس - وخاصة المبتدئين منهم- في مجال الإثراف العلمي، ولعل هـا يؤكلد وجـود مشكلة حقيقية جـليرة بـالدراسة 
- المصدر الثالث : فحص وتحليل الإطـار التشريعي ( قانون تنظيم الجامعات ومواده المنظمة للإثثراف على الرسائل العلمية )، اللوائح الداخلية المنظمة للدراسات العليـا ببعض الجامعات المصرية، فبنظرة تحليلية فاحصة ناقدة لتلك المواد المنظمة للإثـراف العلمي بـالجامعـات المصرية فنيسا وإداريـا وماليًا

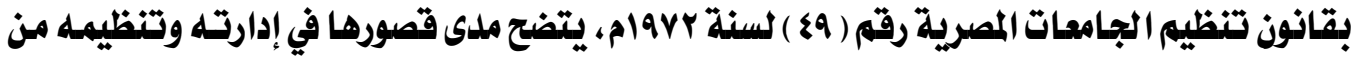
الناحية التشريعية، وترك كثير من الفجوات والثفرات فيما يخص معاييره وشروطه - وسوف يعرض الباحث تحليلًا نقليًا لهذه المواد في المحور الخاص بـالوضع الراهن للإثراف العلمي بـالجامعات المصرية

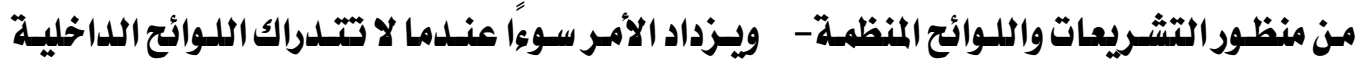
للدراسات العليا بمعظم الجامعات المصرية وكلياتها وأقسامها العلمية هذه الثفرات والفجوات، وكان لنتـائج هــا الفحص والتحليـل للأطـر التشـريعية والقانونيـة المنظمهة للإثـراف العلمي بـالجامعـات المصرية ما يؤكلد وجود مشكلات حقيقية يعانيها على مستوى تنظيمه إداريًا وفنيًا ومالييا.

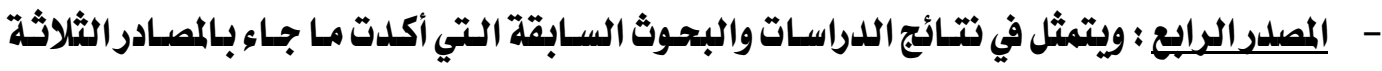
السابقة حول ضعف الإشراف على الرسائل العلمية بمعظم الجامعـات المصرية، ومنها دراسـات تنتاولت

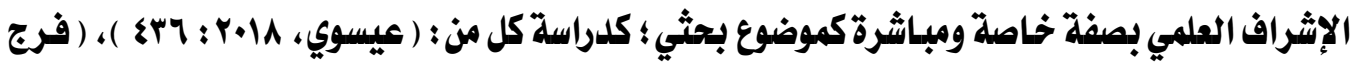
،

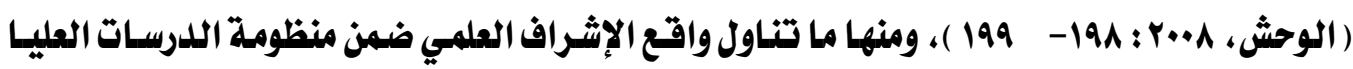

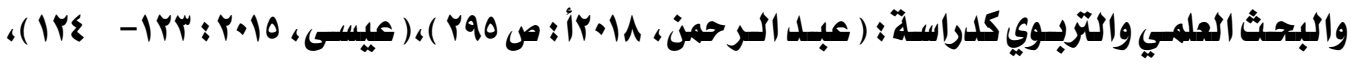

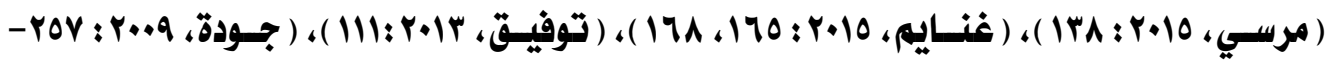
ro9 )، حيث توصلت نتـائج هـده الدراسـات إلى أن الإثـراف العلمي بـالجامعـات المصرية يعـاني جوانب ضعف وقصورومشكلات وسلبيات متعددة؛ من حيث ضعف إدارته وتنظيمه ، وقلة المخصصـات المالية المناسبة للمشرفين، وغياب معايير واضحة لاختيار المشرفيز تراعي رغبة الباحث وحريته في اختيـار مشرفه والعكس وتضمن التوافق بينهما، وغياب التحليـل الواضِح والـدقيق لأدوارومسئوليات المشرف والباحث، وضـف قيـام بعض المشـرفين والطلاب بتلك الأدواروالمسئوليات إضـافة إلى قلـة المعرفة الكافية بـالحقوق والواجبات خلال العملية الإثرافية، وقلة وجود ضوابط تنظم العلاقة الإثرافية بـين

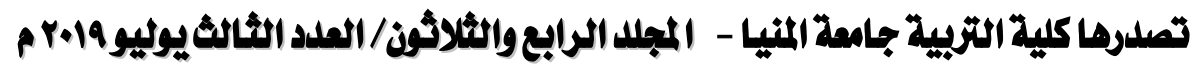
gamel_abdo59@yahoo.com

http://ms.minia.edu.eg/edu/journal.aspx 
المشرف والباحث ؛ وقد أرجعت هـذه الدراسـات والبحوث تلك المشكلات والسلبيات إلى أسباب كثيرة ومتعددة منها : ما يخص أعضاء هيئة التدريس المشرفين والطلاب البساحثين، والتشريعات والسياسـات البحثيـة المنظمهة، والمؤسسـة والبيئهة البحثيـة والمنـاخ الجـامعي، قلـة الأنشطة والـبرامج التدريبيـة للتنمية المهنية في مجال الإثراف العلمي ...إلخ، وسوف يعرض البحث لنتـائج تلك الدراسـات والبحوث وغيرهـا بشيء من التفصيل والإيضساح في موضعه من المحسور الخـاص بلدراسة الواقع والوضع الـراهن

$$
\text { لإلإثراف العلمي بـالجامعات المصرية. }
$$

ولعل ظـاهرة ضعف جـودةكثير من الرسـائل العلمية ( ماجستير ودكتوراه ) بـالجامعـات المصرية،

واتتشار السرقات والاتتحال العلمي بها، وبعد كثير منها عن الضبط المنهجي وأخلاقيـات البحث العلمي يعد مؤشرًا ودليلًا واضحًا- في كثير من الأحيان- على ضعف جودة عملية الإشراف العلمي عليها، مع الأخدذ في الاعتبار أن هذه الظـاهرة تتشـارك فيها عوامل وأسباب كثيرة غير الإثراف العلمي مثل : مستوى الطالب الباحث وقدراته، البيئة والمنـاخ البحثي وتسهيلاته، إدارةوتنظيه اللدراسـات العليـا...إلخ، وتجـاه هـدا الوضع المضطرب لنظام الإشراف على الرسائل العلمية بـالجامعات المصرية، سعى البحث الحسالي جاهـلًا إلى وضع رؤلة تطويرية مقترحة للإشراف العلمي بـالجامعات المصرية في ضوء واقعه ووضعه الراهن، والاستفادة من خبرات متنوعة لثلاثة جامعـات من قـارات مختلفة هي ( جامعة أكسفور الإنجليزيـة بـأوربـا، جامعة نيو سوث ويلز بسيدني الأسترالية، جامعة أوكلاند النيوزيلندية بـآسيا )، وهي جامعات متميزة ورائدة في مجال الإشراف والبحث العلمي وتحتل مراكز متقدمة بالتصنيفات العالية للجامعات. وفي ضوي المصادر السابقة، تبلورت مشكلة البحث الحالي في السؤال الرئيس التالي: كيف يمكن تطوير الإثراف على الرسـائل العلمية بـالجامعـات المصرية في ضوي وضعه الـراهن، والاستفادة من خبرات جامعات ( أكسفورد الإنجليزية ، جامعة نيو سوث ويلز بسيدني الأسترالية، جامعة أوكلاند النيوزيلندية )؟ ويتفرع عن هذا السؤال الأسئلة الآتية :

ا- ما طبيعة الإثراف العلمي وأسسه النظرية والفكرية في الأدبيات التربوية المعاصرة:

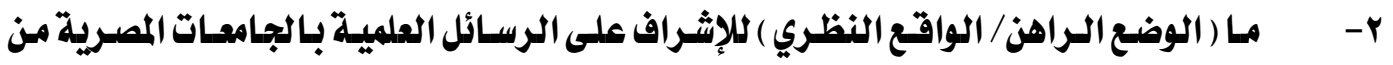




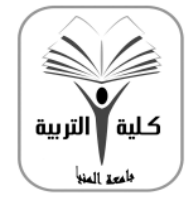

$$
\text { مجلة البحث في التزبية وملم النفس }
$$

كالية مُتملةةمن الميية القومية لضمان جودة التمليم

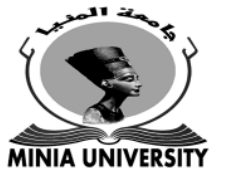

منظـور التشـريعات السيـاسـات واللوائح المنظهـة واللدراسـات والبحـوث السـابقة والأدبيـات التربويـة

المعاصرة؛

r- ما أهم ملامح الإثراف العلمي بجامعة أكسفورد الإنجليزية، ونيوث سوث ويلز الأسترالية، وأوكلاند

النيوزيلندية؛

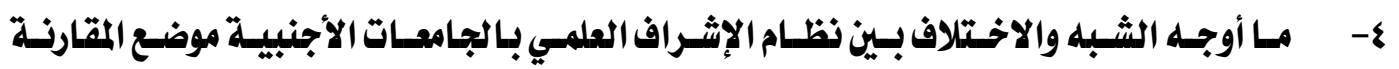

والجامعات المصرية، وما أوجه الاستفادة منها في ضوي محاور البحث وحلدوده الموضوعية؛

0- ما ملاح وأبعاد الرؤية المقتر حة لتطوير الإثراف على الرسائل العلمية بـالجامعات المصرية في ضوي

واقعه ، والاستفادة من خبرات الجامعات الأجنبية موضع المقارنة؟

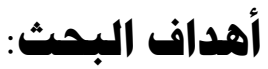

هدف البحث الحالي إلي وضع رؤلة مقترحة لتطوير الإثراف على الرسسائل العلمية بـالجامعات المصرية في ضوي واقعه ، وخبرات بعض الجامعات الأجنبية، وذلك من خلال :

l - تعرف طبيعة الإثراف العلمي وأسسه النظرية والفكرية في الأدبيات التربوية المعاصرة . r - تشخيص وتحليل الوضع الراهن لواقع الإثراف على الرسائل العلميـة بـالجامعات المصرية من منظور

التشريعات والسياسات البحثية واللوائح المنظمة، واللدرسات والبحوث السابقة.

r - استعراض ووصف أهم ملاح خبرات بعض الجامعات الأجنبية ( أكسفورد الإنجليزية، ونيوث سوث ويلز

الأسترالية، وأوكلاند النيوزيلندية ) في مجال الإشراف على الرسائل والبحوث العلمية.

ع- تحليل مقارن لأوجه الشبه والاختلاف بـين خبرات الجامعات الأجنبية موضع المقارنة، واستخلاص

بعض الدورس وأوجه الاستفادة منها في تطوير الإشراف العلمي بـالجامعات المصرية.

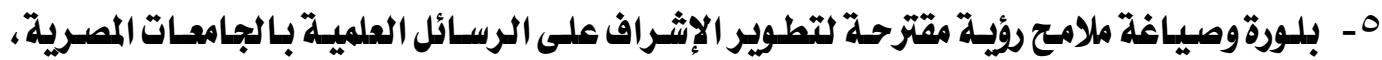

متضمنة أبعاد ومقترحات وتوصيات إجرائية للتطوير في ضوي محاور البحث وحدوده الموضوعية.

أهمية البمث:

تتحلد أهمية البحث ومجاله وموضوعه من الناحية النظرية والتطبيقية في النقاط الآتية:

ا- أهمية عملية الإثـراف في إعـاد البـاحثين وتنمية مهاراتهم وقدراتهم البحثية، وزيـادة فاعلية

\section{$r \varepsilon r$}

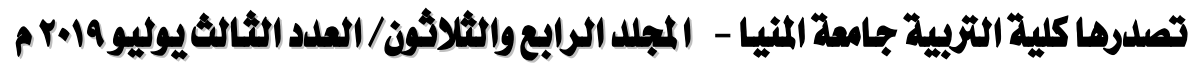

gamel_abdo59@yahoo.com $\quad$ http://ms.minia.edu.eg/edu/journal.aspx 
البحث العلمي و تحسين جودة رسائل الماجستير واللدكتوراه.

إلقاء الضوء على الأسس النظرية لطبيعة الإثراف العلمي وأبعاده ؛ لإثراء المكتبة التربوية بـإطسار نظري مفـاهيمي حول طبيعة عمليـة الإثـراف العلمي ؛ ممـا قـل يسهم في سلد الفجـوة والنقص في الأدبيات التربوية التي تتناول هذا المجال والموضوع البحثي الجيوي. رصد وتحليل واقع عملية الإثراف العلمي على الرسـائل العلمية بكليـات التربية، والكثف عن العقبات والصعوبـات والمشكلات والعوامل المؤثرة في عملية الإثراف وتحلد من فاعلية دور المشرف على الرسائل العلمية، وتوجيه نظر المسئولين إليها لاتخاذ إجراءات تصحيحية حيالها.

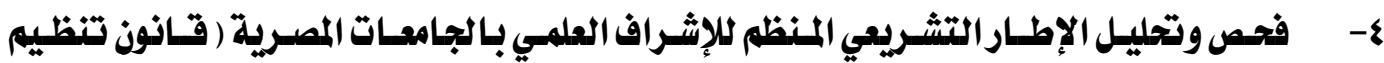
الجامعات واللوائح اللداخلية للدراسـات العليـا )، وبيـان أوجه القصـوروالضعف فيهـا، وتوجيه الانتبـاه إلى تطويرهـا مـ أجل تحسـين مستوى وجـودة الإثـراف على الرسـائل العلميـة، ومن ثم الارتقاء بجودة البحث العلمي.

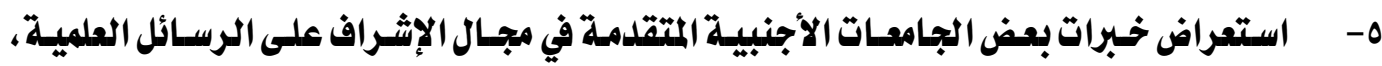
ومقارنتهـا بـالجامعـات المصرية ؛ لاستخلاص أوجـه الاستفادة والتطـوير لنظـام الإثـراف العلمي بالجامعات المصرية. 1- تقليم رؤية مقتز حة لتطوير الإشراف على الرسائل العلمية بـالجامعات المصرية متضمنة مقترحات وتوصيات إجرائية للتطوير الفعلي، من خلال أطرِ مقترحة لمواصفات ومعايير اختيـار المشرفين،

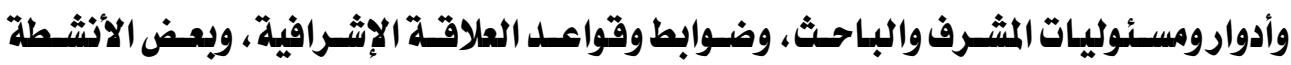
والوسائل المقتز حة للتنمية المهنية في مجال الإثراف العلمي، وتزويل المسئولين عن البحث العلمي والدراسات العليا في الجامعات المصرية بهذا الرؤية وأطرها وأبعادها. - - يمكن أن يفيد هذا البحث ونتائجه كيًا من : - - أعضاء هيئة التلدريس المشرفين على الرسـائل العلمية : حيث يبصرهم بـأدوارهم ومسئولياتهم تجاه طلابهم الباحثين، وكيفية أدائها بفاعلية، ويوضح حلدود العلاقة الإثرافية بينهم وبين طلابهـه، وتـوعيتهم بـالإطـار التشـريعي والقـانوني المـنظم للإثـراف العلمي إداريــا وماليـا، $r \varepsilon r$

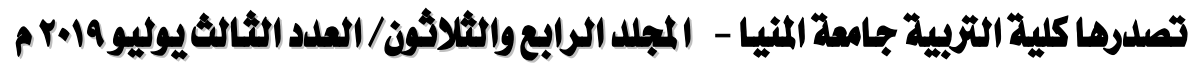
gamel_abdo59@yahoo.com

http://ms.minia.edu.eg/edu/journal.aspx 
وحقوقهم وواجباتهم خلال عملية الإشراف من أجل إنجاز رسالة علمية جيدة خلال المدة المحددة. - الطلاب الباحثين بهرحلتي الماجستيروالدكتوراه : يبصرهم بأدوارهم ومسئولياتهم، وأدوارمشرفيهم ومعوقات القيام بها، وحدود العلاقة الإثرافية بينهما لإنجاز الرسالة العلمية بشكل متميز. - المؤسسة البحثية ( الجامعات والكليات ) : حيث إن إنتاج رسائل وأبحاث علمية متميزة من خلال إثراف علمي متميزيسهم في تقدم المؤسسة البحثية وتصنيفها محليـا وعالئًا، وبعيد ثقة المجتمع المحلي ومؤسساته المختلفة في تتائج أبحاثها واعتمادها في عمليات التطوير واتخاذ القرار.

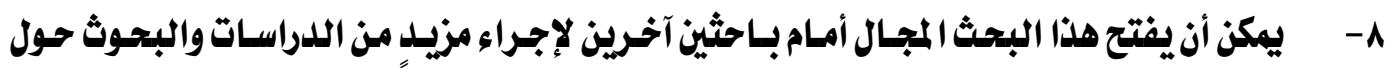
الإشراف العلمي والاتجاهات الحديثة أووخبرات الجامعات الأجنبية والعربية في تطويره؛ مما قد يسهم في سلد الفجوة والندرة في اللدراسات المصرية والعربية لهذا المجال والموضوع كقضية ومجال

$$
\text { هصطات البمث مهم. }
$$

يتناول البحث المصطلحات الآتية ( تطوير ، الإثراف العلمي، الرسيائل العلمية ) ويمكن توضيح

$$
\text { - هله المصطلحات وإزالة الفهوض عنها علي النحو الآتي: }
$$

التطوير في اللفة العربيةة : من ( تَطَرَّرَ) بمعنى تحول من طورٍ إلى طور، والتطوير مصدر من الفعل طَوََّ، أي نقله من هيئة إلى هيئة ومن حاله إلى حالة، والتَطَوَّر: هو التفيير التدريجي اللدي يحدث في بنية الكائنسات الحيـة وسلوكها، ويطلق أيضًا على التفيير التـدريجي الـذي يحلدث في المجتمع أو العلاقات أو

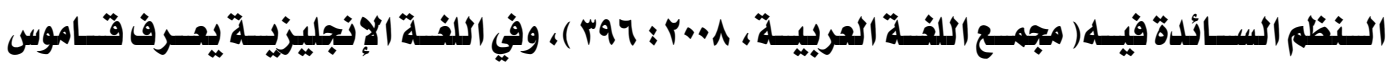
التربيةDictionary of Education التطوير : بأنه نمو أو تفيير في بنيـة أو وظيفة أو تنظيم مـا (Carter, 1993: 175). وأما في الاصطلاح فيعرف التطوير بأنه : تخطيط يستهدف إحرازتفييرات في

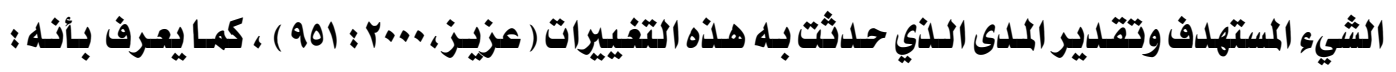

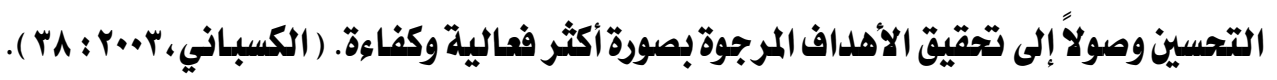

\section{$r \leqslant \varepsilon$}

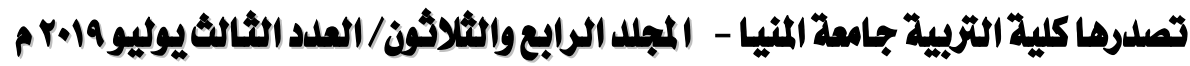
gamel_abdo59@yahoo.com

http://ms.minia.edu.eg/edu/journal.aspx 
ويعـرف البحث الحسالي التطـوير إجرائيـاً بـأنهـ : علميـة تحسـين الإثـراف العلمي على رسسائل

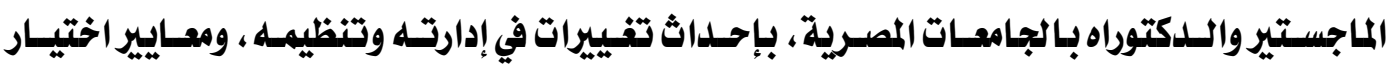
الشرفين وتشكيل لجانه، وتحليد مسئوليات وأدوار المشرفيز والباحثين، وإرساء ضوابطوقواعلد للعلاقة الإشرافية بينهما، وتنمية أعضاء هيئة التدريس المشرفين مهنيـا ؛ ضمانًا لجودة الإثراف العلمي وجعله أكثر كفاءة وفمالية في تحقيق أهداف البحث العلمي وتجويلد مخرجاته من الرسائل العلمية. Scientific Supervision: الإشراف العلمي: يعرف الإثراف من الناحية اللفويلة في معظم معاجم اللفة العربية بـأنه اسم ومصدر من الفعل

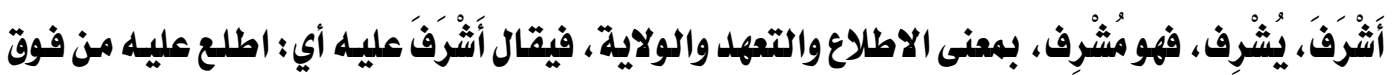

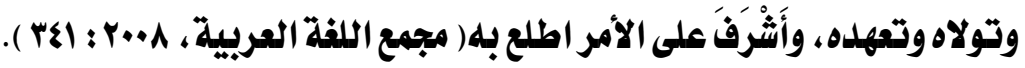
أما اصطلاحًا فيُعرف الإثراف العلمي بـأنه : مسـاعدة الباحث في المضي قُلـمًا ؛ لاتمسام دراسته وبحثه وتذليل الصعوبـات التي يمكن أن تواجهه في عمله البحثي، بقصدل تجويـلـ هـا العمل، وإكسـابه الصفات العلمية التي يمكن الإفادة منها في الجانب التطبيقي( عطا، 1991 : 7 ). كما يعرف بأنه : سلسـة من الممارسات العملية لدراسة شيء مـا بفرض الوصول إلى حقائق جديـدة من قبل شخص مهتم ( الباحث )

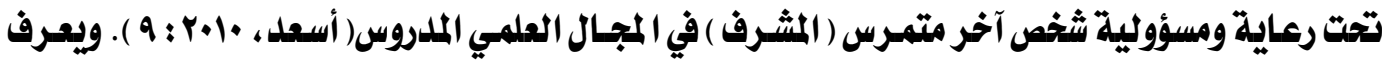
أيضًا بـأنه توجيه أستاذ متخصص لطالب البحث إلى المنهج العلمي السليم في دراسة موضـوع مـا، وكيفية عرض قضايـاه، ومناقشتها، واستخلاص النتائج، وفق المعايير العلمية المقررة ( إيليفا، د. ت : 1 ). وفي ضوء ما سبق، يعرف البحث الإثراف العلمي إجرائيًا بأنه : تعهل عضو هيئة تدلدريس أو أكثر ( أستاذ، أستاذ مسـاعد، ملدرس ) لباحث في مرحلة الماجستير أو الدكتوراه بالرعايـة والتوجيه واللدعم والمساندة لإنجاز رسالته على أكمل وجه ، وذلك بتكليف من ( القسم المختص، والكلية، والجامعة ) في ضوء

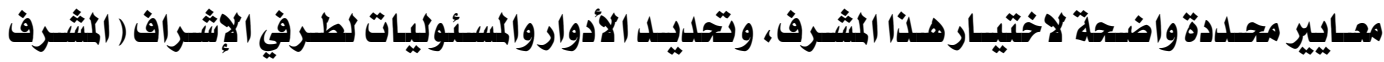
والباحث )، ووضع ضوابط تنظم العلاقة الإثرافية بينهـا، مع اقتراح أنشطة للتنمية المهنيـة المستمرة لعضو هيئة التدريس المشرف في مجال الإثراف؛ تحقيقًا لجودة وكفـائوة وفالية الإثراف، ومن ثم جـودة المخرجات البحثية من الرسائل العلمية. $r \varepsilon 0$

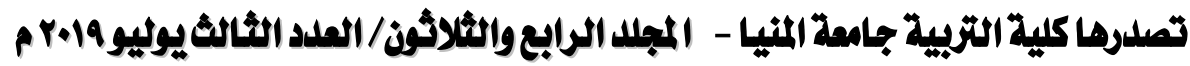
gamel_abdo59@yahoo.com

http://ms.minia.edu.eg/edu/journal.aspx 
Scientific Researches (Master Thesis and Doctoral الرسائل العلمية:

Dissertations).

يُقصل بها بحوث ورسائل الماجستير والدكتوراه التي يقوم بإعلدادها الطلاب البـاحثون بالدراسـات

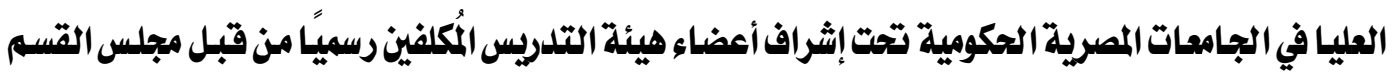
والكلية واللدرسات العليا بالكلية والجامعة بالإثراف على هؤلاء الطابل ورسائلهم العلمية.

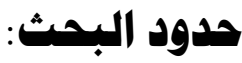

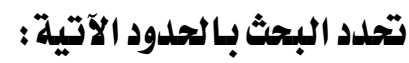
أ- حلدود موضوعية: اقتصر البحث على تقليم رؤيـة مقترحة لتطوير الإشراف على الرسائل العلمية

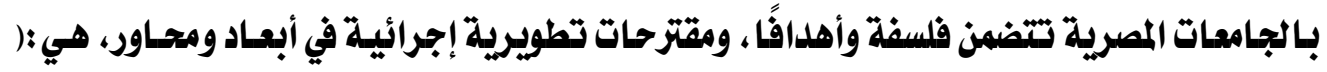
إدارةوتنظيم الإثراف العلمي، ومعاييي اختيار الشرفين وتشكيل لجسان الإشراف، وأدوارومسئوليات

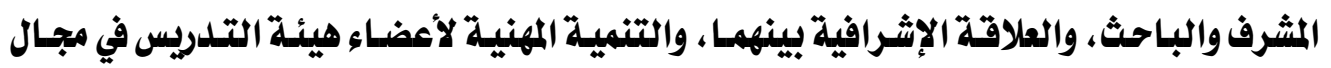

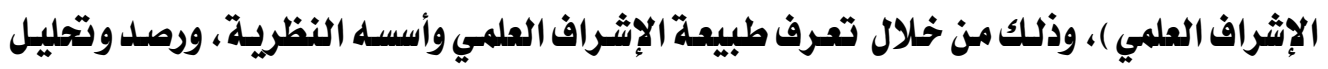
واقعه ووضعه الرراهن - في ضوء المحساوروالأبعـاد السابقة- من منظور التشريعات والسياسات والقواذين واللـوائح المنظمة ونتـائج الدراسـات والبحـوث السـابقة والأبيـات التربويـة المعاصـرة، وبالاستفادة من خبرات الجامعات الأجنبية موضع المقارنة.

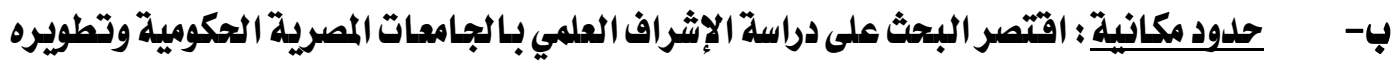

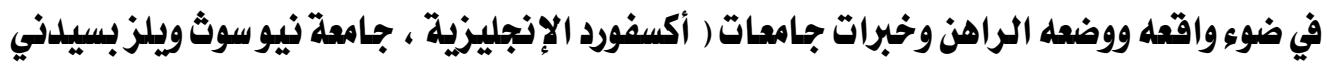

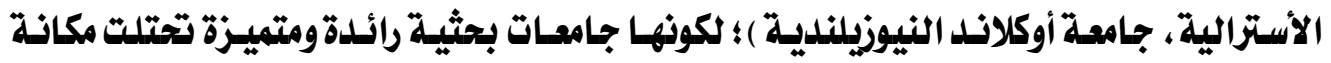

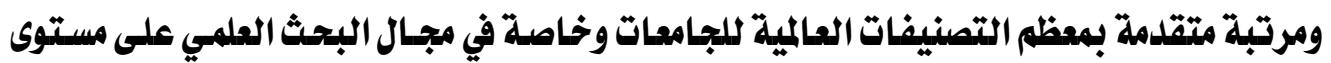

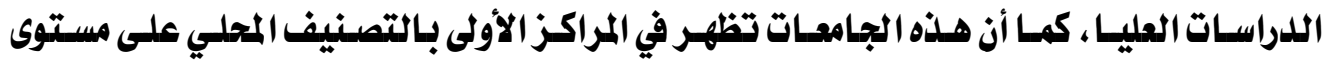

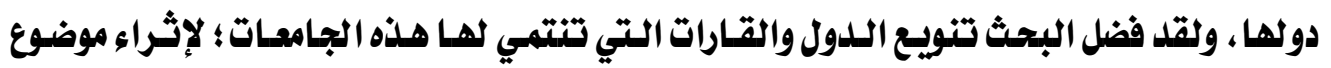
البحث وتعرف خبرات متنوعة في مجال الإثراف على الرسائل العلية للاستفادة منها في بنـاء الرؤيسة التطويرية المقترحة ومحاورها وأبعادها. $r \varepsilon q$

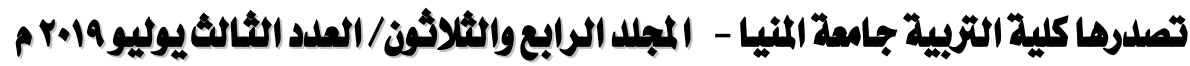
gamel_abdo59@yahoo.com http://ms.minia.edu.eg/edu/journal.aspx 
ج- حسلود زمنيـة: تم الاطـلاع على التشـريعات السياسـات البحثيـة والقـوانين واللـوائح المنظمة للإثـراف العلمي بـالجامعات المصرية المعمول بها خـلال فترة إجـراء البحث ( المهواد المنظمة للإثـراف

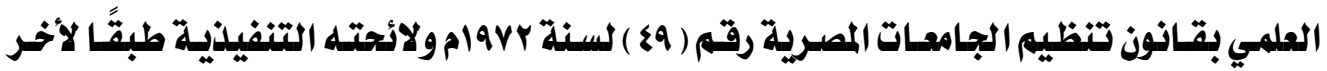
التعديلات، واللوائح الداخلية للدراسـات العليـا ببعض الجامعات المصرية ورقيًا أو إلكترونيـا على مواقع تلك الجامعات )، كما تم الاطلاع على بعض الدراسات والبحوث والسياسات البحثية والوثائق المنظمة من خلال زيـارة المواقع الر سمية للجامعـات الأجنبية موضع المقارنة؛ لتعرف وتحليل ملامع نظام الإثراف العلمي بها وسياساته ووثائقه وتشريعاته وقواعده المنظمة وخهبرات تلك الجامعـات

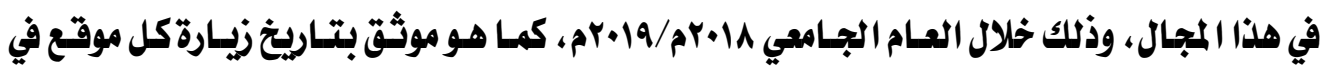
قائمة المراجع. هنهه البصث وخطواته: في ضوء طبيعة البحث ومشكلته وأهدافه وحدوده، استخدم الباحث المنهج المقارن كمسار منهجي شامل يتضمن مداخل متعددة للمعالجة التربوية المقارنة للظواهر والثككات، فهويسى إلى وصف الظاهرة موضـوع البحث في نظم التعليه بـالـدول أو الجامعـات موضـع المقارنة، وتشخيصها وتحليلها وتقسيرها، وموازنة أو منساظرة ومقابلة عناصرها، ثم المقارنة بينها ؛ لاستنتاج وتحليـل أوجه الشبه والاختلاف واستخلاص أوجه الاستفادة، والخـروج بـرؤى ومقتزحسات ونتـائج موضوعية ثثبت صحة فروض الدراسـة

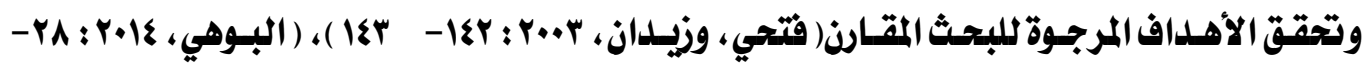

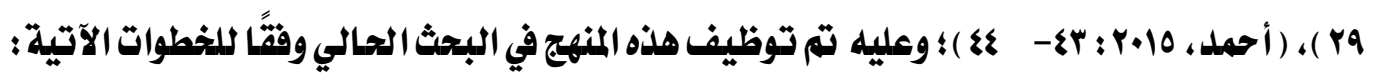
ا- بناء إطار نظري مفاهيمي حول طبيعة الإثراف على الرسـائل العلمية وأسسه وأبعاده في الأدبيـات التربوية المعاصرة.

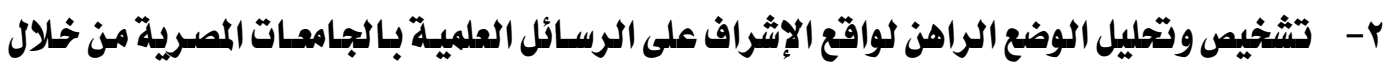
تحليـل وثـائقي للتشـريعات والسياسـات البحثيـة والقـوانين واللـوئح المنظمهة، وتتـائج البحـوث واللدراسات السابقة في ضوء محاور البحث وحلدوده الموضوعية. r- استعراض ووصف أبرزملامح نظـام الإثراف العلمي بـالجامعـات الأجنبية الثلاثة المختـارة في ضوي

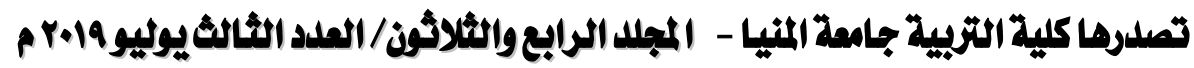
gamel_abdo59@yahoo.com http://ms.minia.edu.eg/edu/journal.aspx 


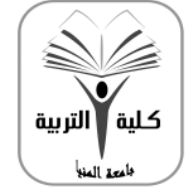

$$
\text { مجلة البعث في التربية وعلم النفس التربية - جامعة المنيا }
$$

كلية مُعتملة من الهيئة القومية لشمان جودة التعليم

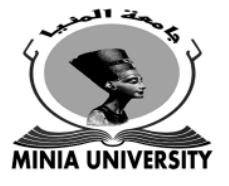

$$
\text { محاور البحث وحدوده الموضوعية. }
$$

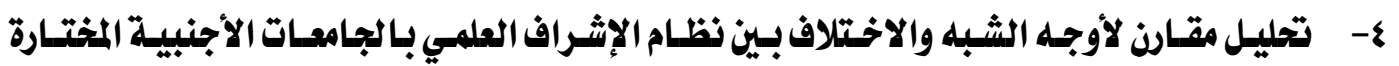

والجامعات المصرية، واستخلاص أوجه الاستفادة منها.

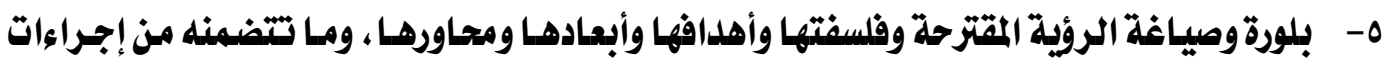

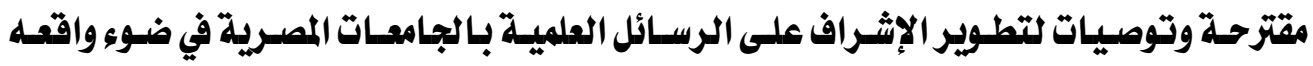
والاستفادة من نتائج التحليل المقارن لخبرات الجامعات الأجنبية الثلاثة موضع المقارنة.

الدراسات السابقة:

حظيت قضية البحث العلمي كمجال وموضوع بحثي بـاهتمام كبير في مصر والوطن العربي؛ إيمانًا

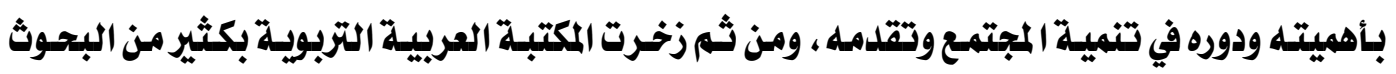
واللدراسات والأدبيات في هذا المجال، إلا أن موضـوع الإثراف العلمي على الطلاب البـاحثين بالدراسيات

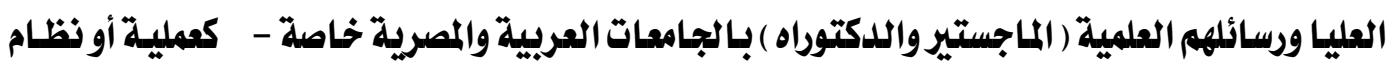

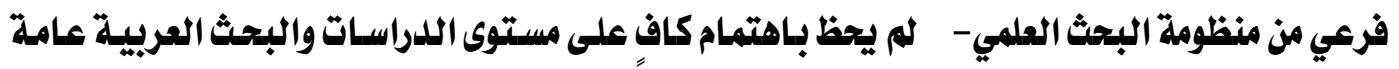

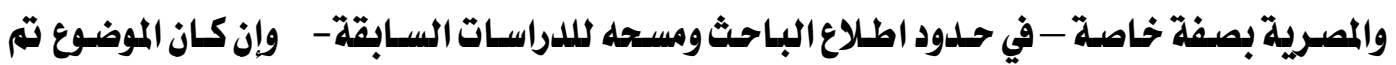
تناوله كمحور أو جزء في الدراسات الخاصة بمجال البحث العلمي والتربوي ؛ إلا إن إفراد بحوث ودراسات

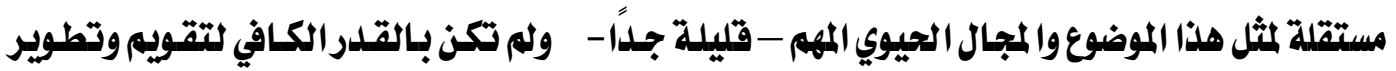
واقع الإشراف العلمي بالجامعات العربية والمصرية خاصة، أمسا على المستوى الأجنبي قتلد حظي موضئه

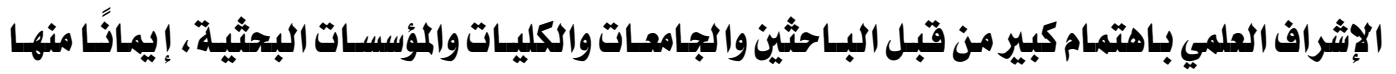
بلدوره في تجويل وتحسين الرسائل العلمية، وتنفية مهارات الطلاب البـاحثين وأخلاقيـاتهم وممارساتهم

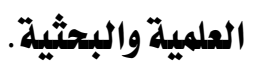

ويعرض الباحث فيما يلي ما تحصل عليه من دراسات مرتبطة بموضوع الإثراف العلمي ارتباطًا

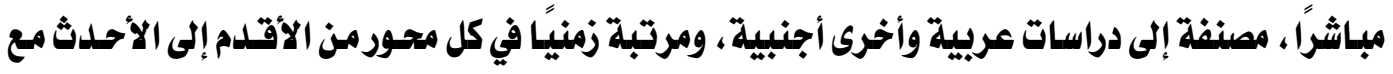

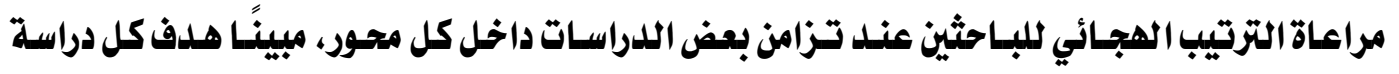

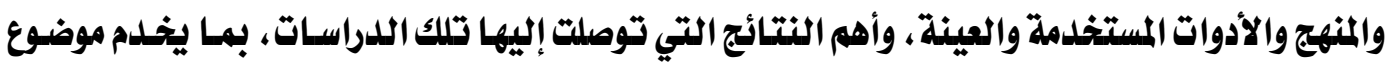

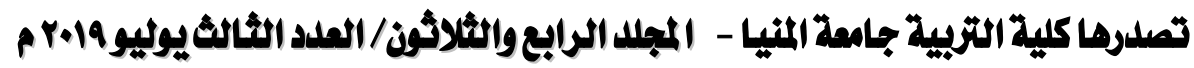
gamel_abdo59@yahoo.com

http://ms.minia.edu.eg/edu/journal.aspx 
البحث الحالي في جوانبه ومحاوره المحتلفة، وذلك على النحو الآتي:

أولاً: الدراسات العربية: العيد:

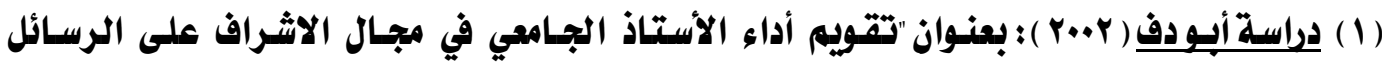
العلمية من وجهة نظر طلبة الدراسـات العليـا"، هـدفت إلى تعرف مستوى أداء الأستاذ الجـامعي في مجال الإثراف على الرسائل العلمية، واستخدمت المنهج الوصفي التحليلي، والاستبانة لتقيييه أداء

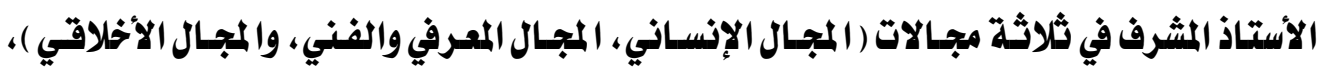
واقتصرت عينة اللدراسة على طلاب اللدراسات العليا في مرحلة الماجستير بكليتي التربية في الجامعة الإسلامية وجامعة الأقصى بغزة، وتوصلت الدراسة إلى أن الإثراف العلمي يحتـاج إلى جهـل ووقت كاف، ومتابعة فنية وإدارية، وأن الإثراف الفعال يتطلب أساتدة يتمتعوز بكفايسات وقدرات عالية، مشيرة إلى ضرورة تقليص الأعباء الإدارية والتدريسية المُوكلة للأساتلة المشرفين.

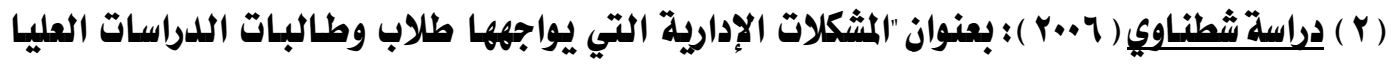
في جامعة اليرموك في مجـال الإثتراف على رسيائلهم الجامعية"، هـدفت إلى تعرف المشكلات التي تواجه طلاب وطالبات الدراسات العليا بجامعة اليرموك في مجسال الإثراف على رسـائلهم من وجهة نظرهم، وتعرف أثر بعض المتفيرات( الجنس، الكلية، اللدرجة التي يـلدرس الطالب لنيلها ) في تصور الطلاب دهذه المشكلات، واستخدمت المنهج الوصفي، معتمدة على الاستبانة، تم تطبيقها على عينة عشوائية من مجتمع الدراسة قوامها ( م1 ) طالبًا وطالبة، وتقت معالجة البيانات إحصائيًا من خلال برنامج (SpSS)، وتوصلت الدراسة إلى مجموعة من النتائج أهمها : أن أبرز المشكلات التي يعاني منها الطالاب في مجال الإثراف على رسائلهم ثثثلت في : صعوبة اختيار المشرف المناسب للموضوع لقلة عـدد المشرفين، وتعقـل إجـراءات اختيـاره، وضعف اهتمـام المشرفين بـالبحث والباحث، وتنـاقض تعليماتهم وسوي تنسيق العمل فيما بينهم.

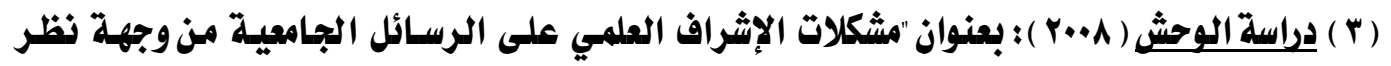
الباحثات : دراسة ميدانية"، هلدفت إلى تعرف مشكلات الإثراف العلمي على الرسـائل الجامعية من وجهة نظر الباحثات، والكثف عن المعايِير التي ينبفي مراعاتها عند اختيـار المشرفين، واستخلدمت $r \leqslant q$

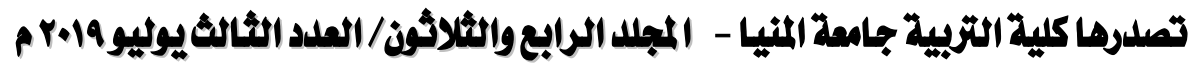
gamel_abdo59@yahoo.com http://ms.minia.edu.eg/edu/journal.aspx 
اللدراسـة المـنهج الوصفي معتمـلة على الاستبـانة الـتي طُبقتـت على عينـة من الباحثـات في كليتي

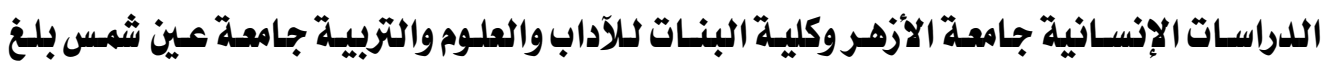
قوامهـا ( •1 ) بـاحثة، وتوصـلت إلى مجموعة مـن المشكلات الخاصة بـالإثـراف العلمي في مجـالات : اختيار المثرف، ملدى استفادة الباحثات من مشرفيهن، وعلاقة الثشرف بالباحثات، وتعدد المشرفين، ومسئوليات وأدوار المشرف.

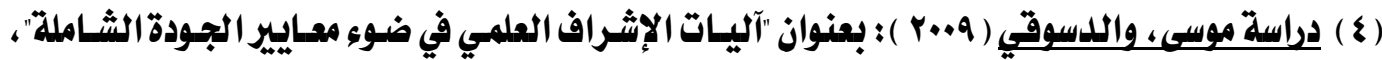
هدفت إلى تعرف طبيعة عملية الإشراف العلمي بأبعادها المختلفة، والتنظير لبعض القضايها المرتبطة بها، وتحديل أدوار المشـرف العلمي، ومعوقتات قيـامه بها، وتعرف مفهوم الجـودة في مجـال الإثـراف العلمي وآليات تحقيقها، وتعرف معايير ( أسس ومبـادئ ) الجـودة الشـاملة في مجـال الإثراف العلمي، واستخلمثت الدراسة المنهج الوصفي التحليلي، وتوصلت إلى مجموعة من النتـائج والتوصبيات لتطبيق الجودة الشاملة في الإشراف العلمي، أهمها : تشجيع المشرفين على تنمية مهاراتهم في مجال الإشراف، وضع حلول لمشكلات الإشراف العلمي، إنشاء شبكة منهجية متكاملة لتخطيط وتطوير وتقوبم البحث العلمي وتطبيق معـايير الجودة الشـاملة في التطوير البحثي وعملية الإثـراف العلمي على الرسسائل الجامعية.

(0 ) دراسة أسعد • • (r) ) بعنوان "توقعات الدور في عملية الإثراف البحثي"، هدفت إلى تحليل طبيعة عملية الإثراف البحثي ( العلمي ) بأبعادها المختلفة، واستقصاء توقمات الدوربطريقة تبادلية بسين كل من الباحث والمشرف في كلية التربية جامعة تعز اليمنية، ومقارنة هـذه التوقعـات، واستخدمت الدراسة المنهج الوصفي التحليلي، معتملة على قائمة أدوارومسئوليات الإشراف من إعداد موسيس (Moses, 1985) وما تم عليها من تطويرات وتعديلات من قبل بـاحثين آخرين، مع تصرف محدود

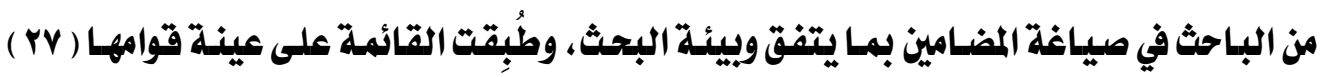

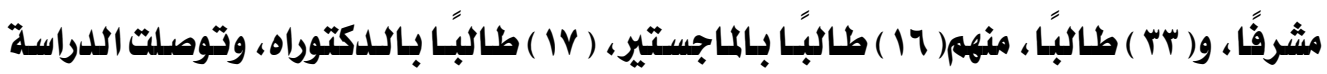
إلى قائهـة نهائيـة لأدوارومسئوليـات طـرفي عمليـة الإثـراف البحثي ( المشـرف /البـاحث ) في كليـة التربية جامعة تعز، واختُمت بمجموعة من المقترحسات والتوصيات التي قد تسهم في تحقيق هـده ro.

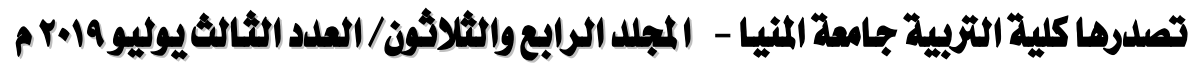
gamel_abdo59@yahoo.com

http://ms.minia.edu.eg/edu/journal.aspx 
الأدوار خلال عملية الإشراف البحثي على الرسائل العلمية الجامعية.

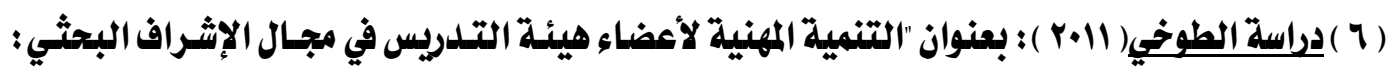
تصور مقترح"، هدفت إلى تعرف طبيعة الإثراف البحثي ( العلمي )، والأبعاد المختلفة لدور المشرف، وعرض خهبرات بعض الجامعـة الأجنبيـة ( كمبرديج ومانشستر بـإنجلترا، ادنبره بـاسكتلندا، سيلدي وملبورن بأستراليا، جامعة هونج كوذج ) في التنمية المهنية لأعضاء هيئة التدريس في مجال الإثراف البحثي، والوقوف على الاحتياجات التدريبية لأعضاء هيئة التدريس بـالجامعات المصرية في هدا المجال، واستخدمث المنهج الوصفي معتملة على استبانة لتحليـل الاحتياجـات التدريبية والأثطة

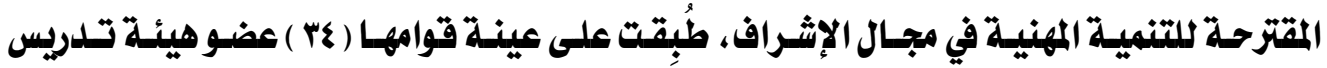
بجامعة القاهرة، وتوصلت اللدراسة إلى تحليد الاحتياجات التلدربيية المهمة لأعضاء هيئة التدريس في مجـال الإثـراف البحثي، وكـان أهمهـا : المعرفة الكافيـة بـاللوائح والقوانين الـتي تحكم عمليـة الإثراف البحثي، تقهم طبيعة الإشراف البحثي، تعرف أخلاقيات الإشراف البحثي. ( ) د ( ) ميدانية من وجهة نظر أعضاء الهيئة التدريسية وطلبة الماجستير والدكتوراه )"، هدفت إلى تعرّف واقع الإثراف العلمي على رسائل الماجستير واللدكتوراه بكليات العلوم الإنسانية في جامعة دمشق من وجهة نظـر أعضـاء الهيئة التدريسية وطلاب اللدراسـات العليـا ( ماجستير ودكتوراه )، واستخدمث المـنهج الوصـفي التحليلي، معتمـلة على اسـتبـانة تم تطبيقهـا على عينـة مـن طـلاب الماجسـير والدكتوراه بلغ قوامها ( م.r ) طالباً وطالبة، وعينة من أعضاء هيئة التدريس المشرفين بلغ قوامها ( 00 ) عضواً، وتوصلت إلى مجموعة من النتائج أهمها : أن وجهة نظر طلاب الدراسـات العليـا وأعضـاء هيئة التدريس نحو واقع الإثراف العلمي بكليـات العلوم الإنسانية في جامعة دمشق كانت بلدرجة متوسطة، ولا توجد فروق ذات دلالهة إحصائية حول واقع الإشراف العلمي للعينتين تصزى لمتفيرات البحث ( الجنس، الكلية، نوع اللدراسة ).

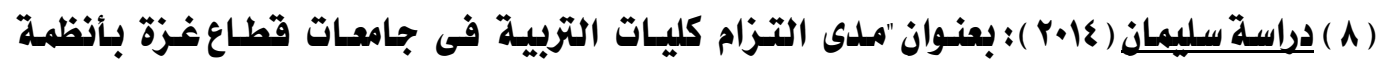
الدراسات العليا ولوائحها في اختيار المشرفين والمناقشين للرسائل العلمية"، هدفت إلى تعرف ملىى rol

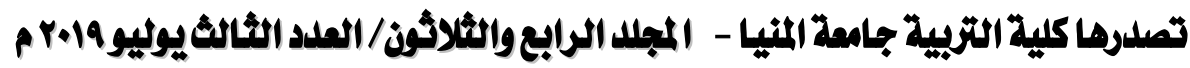
gamel_abdo59@yahoo.com

http://ms.minia.edu.eg/edu/journal.aspx 
التزام كليات التربية في جامعات قطاع غزة بـأنظمة الدراسـات العليـا ولوائحها في اختيـار المشرفين والمناقشين للرسائل العلمية، وتعرف آراء المشرفين والمناقشين ذحو ذلك، واستخدمت الدراسة المنهج

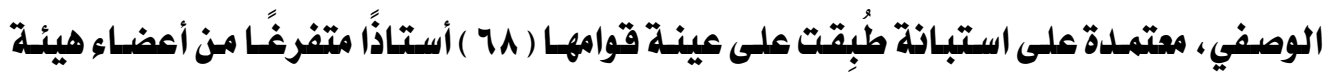
التدريس المشرفين والمناقشين ببرامج الماجستير في كليات التربية بجامعات قطاع غزةة، وتوصلت إلى أن مـلدى الالتـزام مـن قبـل تلـك الكليـات بمعـيـير وأنظمـة الدراسـات العليـا في اختيـار المشـرفيز والمنـاقشـين وتشكيل لجانها جـاء في المرتبـة الأولى، ثم مجـال تخصص المشرف ومؤهلاته، ثم دور اللدراسات العليا في الإثراف على الرسائل، وانتهت اللدراسة بمجموعة من التوصيات، أهمها : ضرورة الالتزام بأنظمة ومعايير الدراسات العليا في تشكيل لجان الإثـراف والمناقشة والحكم، وتفعيل دور مجالس الكليات والأقسام في عملية اختيـار المشرفين والمناقشين، ومراجعة لـوائح الدراسـات العليـا وتقويمها بشكل مستمر في ضوء معايير الجودة عالييًا وعربيًا. ( 9 ) دراسة عساف ( § ( ) ) بعنوان "الإثراف الاكاديمي على الرسائل العلمية في الجامعات الفلسطنية-

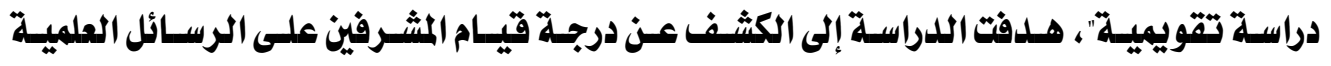
بـالجامعـات الفلسطنية بـأدوارهم الإثرافية من وجهة نظـر طلبتهه، وكدلك الكثف عمـا إذا كان هنـاك فروق ذات دلالـة إحصـائية بـين أفراد العينـة حسول هـده الأدوارتعزى إلى متفيرات ( الجنس، الكلية، الجامعة )، واستخدمت اللدراسة المنهج الوصفي التحليلي، معتملدة على استبانة مكونة من

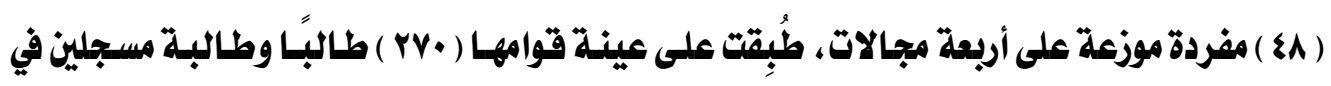
بـرامج الدراسـات العليـا بجـامعتي ( الجامعة الإسلامية، وجامعة الأزهـر )، وتوصلت إلى أن المشرفين يقومون بـأدوارهم الإثرافية بلدرجة متوسطة، وكانت الأدوار المتعلقة بـالنواحي التنظيمية في المرتبة الأولى، ثم الأدوار المتعلقة بتكوين الطالب ومهاراته العلميـة في المركز الرابع والأخير، ولا توجــ فروق دالة إحصائيًا لملدى قيام المشرفين بـأدوارهم تعزى إلى متفيرات اللدراسة.

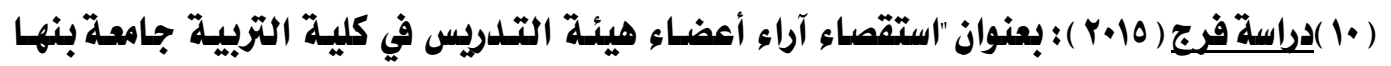
حول بعض مقترحات لتطوير الإثراف العلمي بكليـات التربية في الجامعات المصرية"، هلدفت إلى استقصاء آراء أعضاء هيئة التدريس بكلية التربية جامعة بنها حول بعض المقتزحات لتطوير الإثراف ror

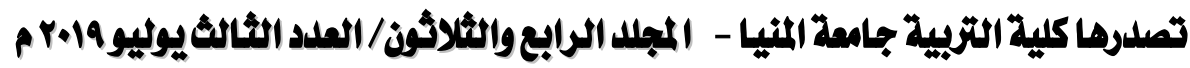
gamel_abdo59@yahoo.com

http://ms.minia.edu.eg/edu/journal.aspx 
العلمي، ووضع بعض التوصيات لتطوير منظومة الإثراف العلمي بكليات التربية في مصر، واستخلمت المنهج الوصفي التحليلي معتمدة على استبـانة لاستطالاع الرأي، طُبقت على عينة قوامهـا ( ع ) عضو هيئة تدريس بكلية التربية جامعة بنها، وتوصلت إلى أن جميع المقترحات التي تم استقصساء الرأي حولهـا حصلت على متوسط عال بـاستثناء مقتزحين همـا : الإثـراف بأسلوب الفريق المتكامل والمتنـوع التخصصات والمهام يرأسه المشرف الرئيس، وضع رغبـة الباحث في الاعتبـار عندل اختيـار المشرفين والمناقشين، وقدمت اللدراسة مجموعة التوصيات أهمهـا : الاهتمـام المستمر بتطوير وتحسين نظـام الإشراف العلمي من جميع جوانبه ، والاستفادة من شبكة الإنترنت في تقديم بـرامج تدريبية في مجـال الإشراف العلمي للباحثين وأعضاء هيئة التلدريس.

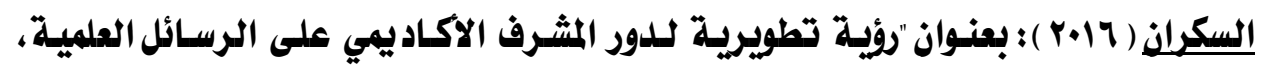
والبحوث التكميلية لطلاب اللدراسـات العليـا أقسـام التربية بجامعة الإمـام محمـل بـ سعود الإسلامية"، هدفت إلى تعرّف واقع الإثراف العلمي على الرسسائل العلمية والبحوث التكميلية لطلاب وطالبات الدراسات العليا بأقسام التربية بجامعة الإمـام محمدل بـن سعود الإسلامية، والكثف عن

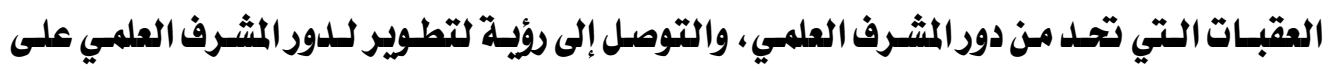
الرسـائل العلميـة، واستخلدمت المنهج الوصفي التحليلي، معتمـلة على استبـاذة طُبقت على ( طالبًا وطالبة بمر حلتي الماجستير والدكتوراه في التخصصات التربوية المختلفة؛ لتعرف واقع البعد المعرفي والإداري والإنساني في عملية الإشراف العلمي، وتوصلت إلى أذ المشرف يقوم بـدوره في عملية الإشراف بلدرجة ضعيفة في الجانب الاككاد يمي والإداري، بينما يقوم بلدوره الإنساني بلدرجة متوسطة، وأن هناك عقبات تحلد من دور المشرف، أهمها : كثرة الأعباءالمكلف بهـا المشرف، وقلة خبرة المشرف، وضعف التزام المشرف بالساعات المكتبية المخصصة للطلاب.

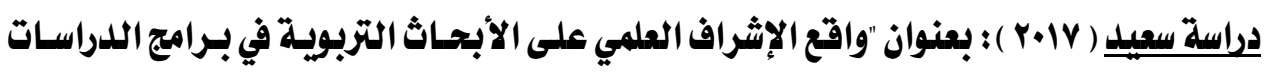
العليا بجامعة أم القرى بمكة المكرمة من وجهة نظر الباحثات في ضوي تخصصهن"، هدفت إلى تعرّف واقع الإثراف العلمي على الأبحاث التربوية بكلية التربية جـامعة أم القرى بمكة المكرمة، من خلال تعرف واقع البعـد المعرفي والإداري والإنسـاني للمشرف في عملية الإثـراف على طالبـات الدراسـات ror

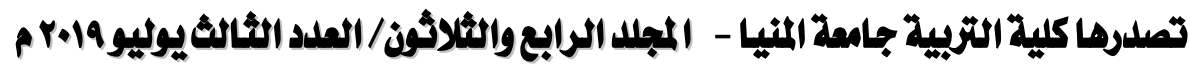
gamel_abdo59@yahoo.com

http://ms.minia.edu.eg/edu/journal.aspx 
العليا، واستخلدت المنهج الوصفي التحليلي، معتمدة الاستبانة طُبقت على ( •؛ ) طالبة بـالتخصصات التربوية المختلفة، وتوصلت اللدراسة إلى مجموعة من النتائج أهمها : أن المشرفين على الطالبات بهدئ الكلية في حاجة إلى زيـادة الاهتمام بالبعد المعرفي في موضوعات الرسـائل التي يشرفوز عليهـا، وأن البعـل الإداري للمشـرفين على الطالبـات منـاسباً نوعـاً مـا، أمسا البعـل الإنسـاني في عملية الإثـراف العلمي من وجهة نظر الطالبات عينة الدراسة متدلٍ بلدرجة كبيرة، وأن ( • ٪ ) منهن يعانين من إخفاق

$$
\text { المشرفين في الاهتمام بـالعلاقتات الإنسانية. }
$$

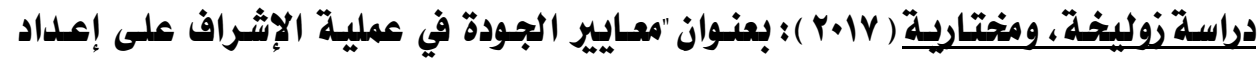

الرسائل الجامعية : دراسة فرقية بين آراء الطلبة وآراء هيئة الإشراف"، هدفت إلى تعرف الفروق بين آراء الطاب وهيئة الإثراف فيما يخص ملدى توافر معايير الجودة العامة في عملية الإثراف على الرسائل العلمية، واستخدمت الدراسة المنهج الوصفي التحليلي، معتمدة على استبانة مكونة من( •r ) مفردة موزعة على ثلاثة معايير ( المعيـار الإنساني، المعيـار التنظيمي، المعيـار العلمي )، طُبقت على عينة قوامها ( §ه ) طالبًا من طلاب قسهم علم النفس وعلوم التربية بجامعة وهران بـالجزائر ، وعينة قوامها ( عه ) أستاذًا مشرفًا في نفس الأقسام، وتوصلت نتائجها إلى وجود فروق بين آراء هيئة الإشراف والطلاب في ملى توافر المعيار التنظيمي لعملية الإثراف، وعلدم وجسود فروق بـين أفراد المينتين في الميار العلمي والإنساني.

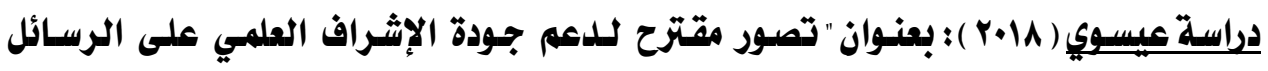

الجامعية بكليات التربية في مصر"، هدفت إلى تعرف طبيعة الإثراف العلمي على الرسائل الجامعية التربوية، ودورومهارات الأستاذ المشرف في عملية الإثراف، ودورومهارات الطالب الباحث في إعداد وكتابة الرسائل العلمية، وملدى اضطراب قيه وأخلاقيـات البحث العلمي للديه ، ومعـيير ومؤشرات جودة وفمالية الإشراف العلمي، واستخلدمث المنهج الوصفي، وتوصلت إلى تصـور مقترح لـلدمه جـودة

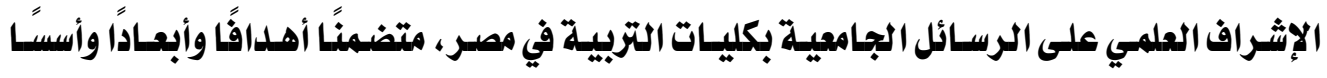
للإثراف العلمي على الرسائل الجامعية التربويـة، وتقديم توصيـات لتنفيـذ كل بعلد من أبعـاد هـدا 
دراسة عبد الرحمن ( 1 ا•rب ) : بعنوان "الإثراف العلمي على رسائل الماجستير والدكتوراه بكليات

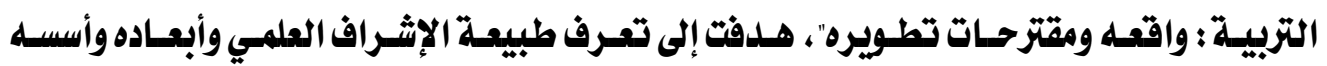
النظريـة، واسـتخدمث اللدراسـة المـنهج الوصفي وإجراءاتـه لرصـل وتحليـل الوضـع الـراهن لعمليـة الإثراف العلمي على رسائل الماجستير والدكتوراه بكليات التربية في مصر، وعلى ضوي الوضع الراهن توصلت الدراسة إلى مجموعة من المقترحات العامة لتطوير الإثراف العلمي بكليـات التربية في مصر، وقدمت مجموعة من الدراسات والبحوث المستقبلية المقترحة في هذا المجال. ثانيا: الدراسات الأجنبية:

دراسة فيرناندو (Fernando, 2004) ؛ بعنوان"علاقة الأساليب الإشرافية بالرضـا والفعالية اللذاتية لطالب الإرثـاد النفسي في مرحلة الماجستير"، هـلـفت إلى تعـرف العلاقة بـين الأسلوب الإثرافي الذي يتبعه المشرف ومستوى رضا الطلاب عز عملية الإثراف، واستخدمت الدراسة قائمة

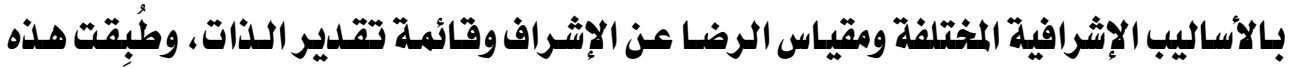
الأدوات على عينة من طلاب الماجستير في الإرشاد النفسي قوامها ( (A ) طالبسا، وتوصلت اللدراسة إلى وجود علاقة دالة إحصائيًا بين الأسلوب الإثرافي المستخلدم ومستوى رضسا الطلاب عن العملية الإثرافية، وكانت أكثر الأسـاليب المُرضية من وجهة نظـر الطلاب : أسلوب العلاقتات التبادلية الحساسة، والأسلوب الجذاب، والأسلوب الموجه نحو المهمة البحثية، وأكلدت اللدراسة على أهمية الاستفادة من تلك النتائج في تحسين عملية الإثراف، والتنمية المهنية للمشرفين وتدريبهم على الأسـاليب الإشـرافية المُرضية والمناسبة لطلابهـه، وفهم العوامل المؤثرة في مستوى رضسا طـلاب اللدراسات العليا عن الإثراف على رسائلهه. دراسة سكيرتوروتش (Skeritte\& Roche, 2004) ؛ بعنوان "نموذج بنائي لتقييي الإشراف على الدراسات العليا : دراسة حالـة "، هـفت إلى تعرف طرائق التقويم الذاتي التي يستخدمها

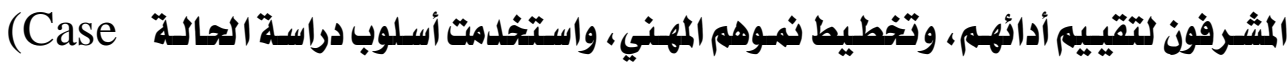
Study) و واستبيان طُبق على عينة من الطلاب بجامعة أستراليا ممن بجثوا تحت إثراف نفس المشرف في مرحلتي الماجستير والدكتوراه، وتوصلت الدراسة إلى أن أهم مؤشرات الإشراف الفعال : ros

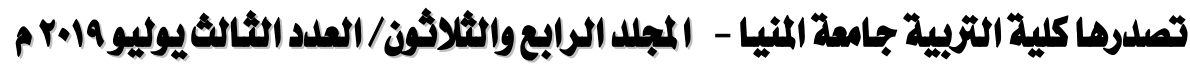
gamel_abdo59@yahoo.com

http://ms.minia.edu.eg/edu/journal.aspx 
السمعة الجيلدة للمشرف في مجال الإشراف والبحث، وقدرته على تنمية علاقة إثرافية إيجابية مـع طلابـه البـاحثين من خـلال الوفـاء بــأدواره والتزاماتـه، والـتي من أهمهـا الالتـزام بهواعيــ اللقاءات الإثرافية المستمرة والدورية.

دراسة أرمسترونج (Armstrong, 2005) ؛ بعنوان "تأثير أساليب الإشراف المعرفية على نوعية الإثراف على البحوث في التعليم الإدارة التربوية"، هلدفت إلى تعرف أثر الأسلوب المعرفي للمشرف في جـودة الإشـراف العلمي على الطلاب في بحوث التعليه والإدارة التربويـة، واستخلمت اللدراسـة المنهج الوصفي، وشارك فيها مجموعة من الطلاب والمشرفين بلغ عددهم ( الكلية الجامعية في لندن، طُبق عليهم مقياس العبء المعرفي لسراستوز (Tharston) ؛ لقيساس اتجاهاتهم ومعرفة آرائهم ووجهات نظرهم حول جودة الإثراف من خلال الأسلوب المعرفي، وتوصلت اللدراسة إلى مجموعة من النتائج تشير إلى أن جودة الإشراف تزداد بشكل واضح إذا كان المشرف أكثر تحليلًا في أسلوبه المعرفي، وأن الطلاب الذين كان مشرفوهم كذلك، كـانوا أكثر تقدمًا في أبحاثهم، وأن جودة الإشراف والرضـا عنه تتزايـلـ مع تحسن العلاقة الإثرافية بـين المشرفوالطالب، وأن معدلات القصور الواضح في الرسائل العلمية ترجع بشكل جزئي إلى علدم رضا الطلاب عن الإشراف وأسلوبه ، وضعف العلاقة الإشرافية بينهم وبين مشرفيهه. دراسة جور (Gurr, 2007) : بعنوان" التفاوض حول نموذج ديناميكي لموا يمة الأساليب الإشرافية مع الطالب الباحث"، هدفت إلى وضع نموذج للعلاقة الإثرافية بين المشرف والباحث، والعمل على لهى تحسينها من خلال توزيع الأدواروالمسئوليات بينمها ، واستخدمت المنهج الوصفي التحليلي، معتمدة على استبيان طُبق على عينة عشوائية من الطلاب والطالبـات في مرحلتي الماجستير والدلدتوراه؛ لمعرفة أسس وطبيعة الإثراف العلمي والعلاقة الإشرافية من وجهة نظرهم، وتوصلت اللدراسة إلى أن ( اب ٪ ) من مشكلات الإثراف العلمي تتعلق بـالعلاقة الإثرافية بـين المشرف والباحث، وأن أكثر هذه المكالات شيوعًا عدم التزام المشرفين بمواعيد اللقاءات الإشرافية الدورية مع الباحثين. دراسة لي (Lee, 2007) ؛ بعنوان "إعلداد المشرفين الفعـالين : مفـاهيم الإثراف البحثي"، هـدفت إلى تعرف مفاهيم الإثراف على البحوث، وقوائم المهام والأدوار التي يجب على الشرف القيام بها ؛ roq

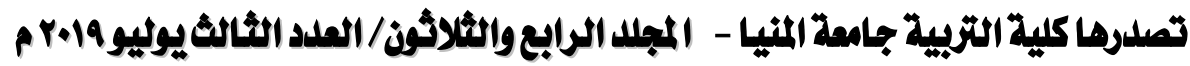
gamel_abdo59@yahoo.com

http://ms.minia.edu.eg/edu/journal.aspx 
مـن أجسل التوصل إلى نهـج مفـاهيمي للإثـراف على البحـوث، وتطبيقي لتطـوير أداء المشـرفين، واستخلدمت اللدراسلة المنهجج الوصفي التحليلي، وتوصـلت من خـلال استعراض الأدبيـات المتعلقة بالإثراف على البحوث إلى ستة مفاهيم أساسية - ليست مفاهيم متضادة أو متناقضة- تسهم في فهم طبيعة الإشـراف على البحـوث، قد يستخدمها المشرفوز لتحليـــ أو توضيح ممارسـاتهم وأدوارهم، وهذه المفاهيم والمناهج هي : النهج العلمي المعرفي، النهج التوجيهي، النهج الـوظيفي، النهج الأخلاقي، النهج الاجتماعي، ونهج التفكير الناقد والتأملي للممارسات والأدوار الإشرافية. دراسة نوليتي، كيلي، ومـيرز (Nulty, Kiley, \& Meyers,2008) ؛ بعنـوان " تمزيـز التميز والاعتراف بـه في الإثتراف على طلاب البحث : إطـار عمل قـائم على الأدلة "، هـلـفت إلى توضيح أربعة أبعـاد للممارسـات أو العملية الإثرافية ( المشرف، الطالب، البيئة البحثية، جـودة الإثراف والتوجيه )، ووضع خريطة للتميز الإثرافي تتضمن أهم الممارسـات والأدواروالمسئوليات الإثـرافية في الأبعـاد الأربعة السـابقة، وتقدليم إرثـادات حهول عمليـات التفكير التي تشؤدي إلى مخرجسات بحثية ناجحة، واستخدمث الدراسـة المنهج الوصفي التحليلي، وتوصـلت إلى نهوذج أو إطار مقترح لتطوير الإثراف العلمي على البـاحثين يتضمن العرض المنهجي والاستراتيجي لعملية الإثراف، تتمثل أهميته في أنه جمع منظم للأدلـة في دعم الممارسـات الإثرافية المتميزة، وأنه سيدعم الممارسـة والـتفكير وتطـوير الممارسـات القائمـة على الأدلـة لتحقيـق التميـز الإثــافي

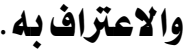

دراسة عابـليزوحسبـانوأحمدي (Abiddin, Hassan \& Ahmad, 2009) بعنـوان "الإشراف البحثي : مدخل للممارسـات الإثرافية الجيلدة، هـلدف إلى استعراض الأدبيـات المتعلقة بالإثراف على بحوث اللدراسـات العليسا، التي تصف أفضل الممارسـات في الإثراف على الطلاب وبحـوثهم، وتحليـلـ حقـوق ومسؤوليات كل مـن الطلاب والمشـرفيز ؛ بهـدف تـوفير بعض المبـادئ التوجيهيـة المفيـلة لطلاب البحـوث والمشـرفين في كتابـة أطروحسات وربسـائل الطلاب وأبحساثهم، واستخدمت الدراسة المنهج الوصفي التحليلي، وتوصلت إلى أن عملية الإثراف مهمة تدريسية معقدة تتطلب التزامًا كبيرًا بـالوقت وا الجهلد من قبـل المشرفين والطلاب، كمـا أنه لايوجلد صيفة واحلة rov

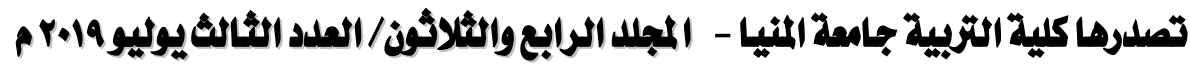
gamel_abdo59@yahoo.com

http://ms.minia.edu.eg/edu/journal.aspx 
للعلاقة بـين الشـرف والطالب، وأنها تعتملد على خصـائص الأثخاص المعنيين ( المشرف والطالب وإدارة الدراسـات العليـا... ) والاختلافـات في الطرق المتقدمة للمعرفة، ومهـام التعلم والإثـراف والمشكلات التي تواجه الطلاب.

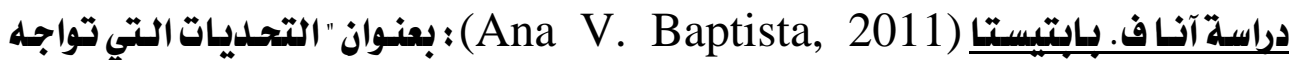
بحـوث السلدكتوراه وجـودة الإثـراف : نهج نظـري"، هـدفت إلى تعرف بعض التحـليـات الـتي تواجـه مؤسسات التعليم العالي والمرتبطة بشكل خاص بـأبحاث الدكتوراه وذوعية الإشراف عليها، وتأثير هذه التحليـات في تحقيق مستويـات ومعايير الجودة في عملية الإثراف على البحوث، واستخلدمث اللدراسة المنهج الوصفي التحليلي، وتوصلت إلى أن أبرز التحليات التي تواجه الإثراف على بحوث الدكتوراه، وهي : ظهـور أنواع جليـلدة من بـرامج وطلاب الـدكتوراه، الحاجـة لتطوير وفهم المهنز البحثيـة والإشـرافية، الحاجـة المتزايـلـة لمناقشـة إجـراءات تهويـل البحـوث، القلق المتزايـلـ حـول أصـالة الأطروحسة، التعريــــ والاستجواب المسـتمر و"مراجعـة" اختصاصـات وأدوارومسؤوليات

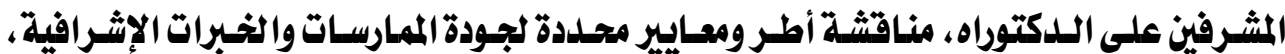
تطوير برامج تلديبية مناسبة لمشرفي الدكتوراه تلبي احتياجاتهم واحتياجات طلابهه. دراسة كيلي (Kiley, 2011) ؛ بعنوان "التطورات في تلدريب المشرفين على البحوث"، هـفتي إلى مناقشة بعض الوسائل والأنشطة المقترحة للتنمية المهنية والتدريب لأعضساء هيئة التدريس في مجال الإثراف العلمي على البحوث، وضرورة وضع مهام يومية للمشرفين على الرسسائل العلمية في

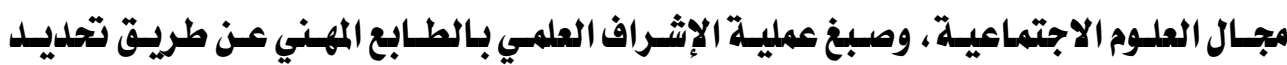

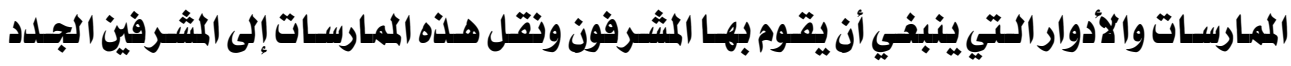
والمبتـدئين، واستخدمت اللدراسلة المنهج الوصفي التحليلي، وقـدمت عـدذا من الوسـائل والأنثطة والبرامج التدربيية في مجال التنمية المهنية للمشرفين، منها : حضورورش عمل في مجال الإشراف، الحلقـات واللقـاءات الإثـرافية، وإلقـاء المحاضـرات حسول طبيــة الإثـراف العلمـي، النـلدوات والمؤتثرات ...إلخ )، مع اشتراط حضور أعضاء هيئة التدريس لمثل هـده الـبرامج والأثطة كشرط أساسي لتعينهم في الإشراف على الرسائل والبحوث العلمية. ros

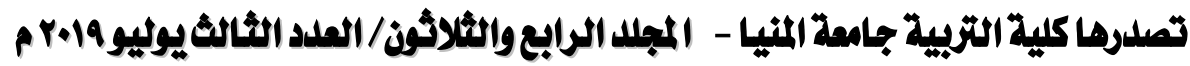
gamel_abdo59@yahoo.com

http://ms.minia.edu.eg/edu/journal.aspx 
( • (1) اسلة حرانتوهنـاكيوإدير(Grant, Hackney \& Edgar,2014) بعنوان "الإثراف

على بحوث الدراسات العليا : رؤية مفاهيمية "متفق عليها" للممارسـات الجيـلة من خلال استعارات مستقاة"، هدفت إلى تعرف دور المشرف على بحوث اللدراسات العليا نحو إنجاز أطروحة الدكتوراه بنجاح من خلال مراجعة شاملة للأدبيات ؛ لتحديل الحالـة الراهنة للمعرفة والنهج اللدولي لهدا الدور، وتضمن ذلك تحليلاً أوليـا لوثائق السياسـات من الجامعـات الأوروبية والأسترالية لمعرفة المعـايير المؤسسـية لهــذا الــلدور، واسـتخدمت الدراسـة المـنهج الوصـفي التحليلـي، والـنهج [ السـردولوجي] كموضـوع روايـة القصس ( المواقف الإثـرافية )، واستطلاعات الـرأي والمقـابلات الشخصية مع مجموعة من المشرفين على طلاب الدراسات العليا، وتوصلت الدراسة إلى مجموعة من النتـائج حـول دور المشـرف، أهمهـا : اتفقت عينـة البحث على أن كل مـا يمكن أن يقدمه المشرفوز

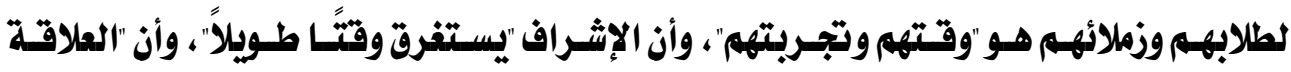
الإثــرافية الجيـــة مـع الطالب ضـرورية"، وأن "الطـلاب يجب أن يتلقـوا تعليمـات مكتوبـة بنّــائة وواضحة وناقدة".

دراسـة علي، واتسيـوز، دهنجـرا (Ali, Watson, and Dhingra, 2016) ؛ بعنـوان" اتجاهات طلاب الدراسات العليا ومشرفيهم نحو عملية الإثراف"، هـففت إلى استكشاف آراء طلاب اللدراسات العليا والمشرفين حول الإثراف على البحوث وعلاقة الطالب بـالمشرف، وتحليـل الأبعـاد الأساسية للعلاقة الإثرافية من وجهة نظر الطلاب والثشرفين، واستخدمت اللدراسة المنهج الوصفي التحليلي، معتمـلة على الاستبييان لاستكثـاف العلاقة بــين الطالب والمشرف، تم توزيعه عـبر

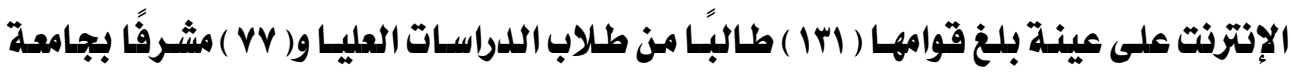
شمسال إنجلترا، وتوصلت النتـائج إلى توافق الطلاب والمشرفين حول خصسائص الإثـراف الفعـال، وأهمها : أن يكون الشرف مهتمًا بـأبحاث الطالب، ويقدم تفليـة راجمة بنـاءة في الوقت المناسب، ويسـاعد الطالـب على إدارة الوقـت بفعاليـة، ويسـاعد الطلاب في تحريد الأدواروالاحتياجات التعليمية، كمـا يعتقر الطلاب أن المشرفين يجب أن يشجعوهم على العمر بشكل مستقل واستثمار الفرص والمحافل العلمية لتقريم أعمالهم البحثية. roq

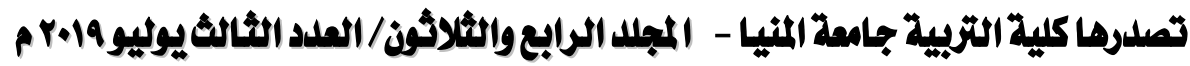
gamel_abdo59@yahoo.com

http://ms.minia.edu.eg/edu/journal.aspx 


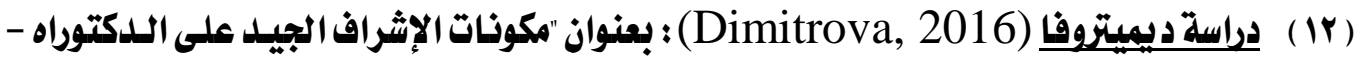

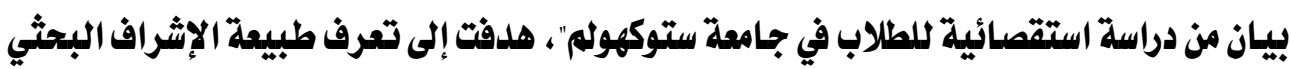

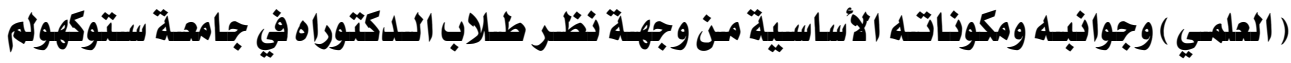

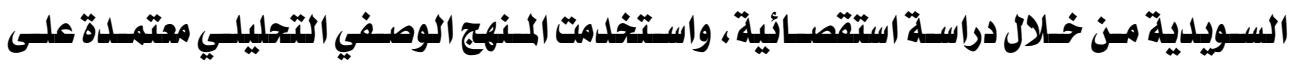

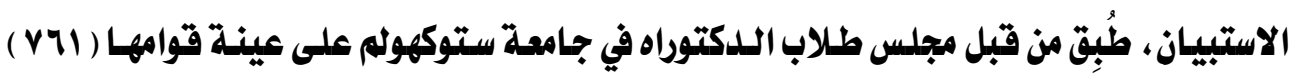

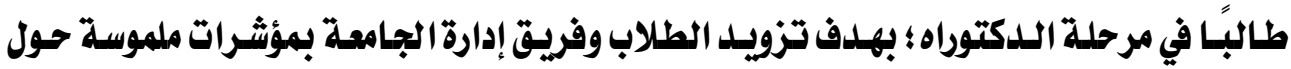
الجوانب المهمة لتجربة الإثراف على طلاب الدكتوراه في الجامعة، وكيف يمكن إجراء التحسينات

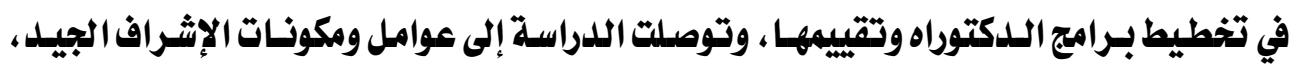
وكذنك العلاقات القوية بين مكونات الإثراف الفعال من حيث : الملاحظات البناءة المقدمة للطلاب، توافر المشرف المتخصص، والوقت الكـافي للإثـراف المستقبلي، إومكانية تـوفير العمل المستقل والبيئة الإشرافية والبحثية الإبداعية اللاعمة لطلاب الدكتوراه.

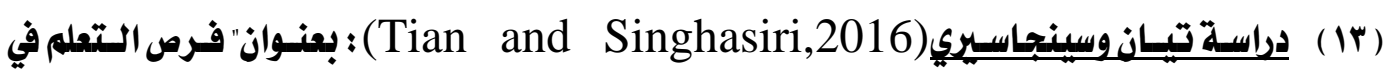

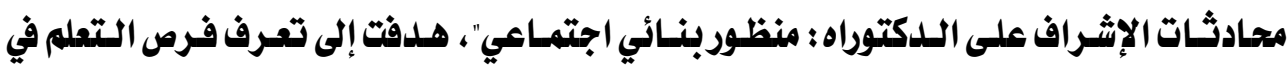

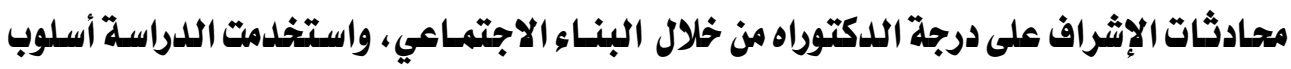
دراسة الحالة النوعية (Case Study) لاستكاف فرص التعلم واكتساب المهارات البحثية من

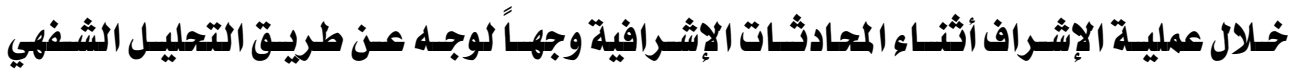

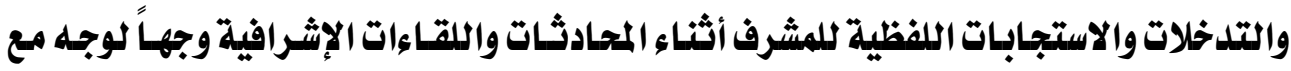

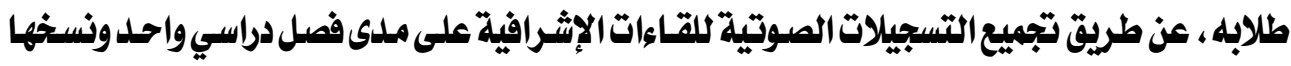

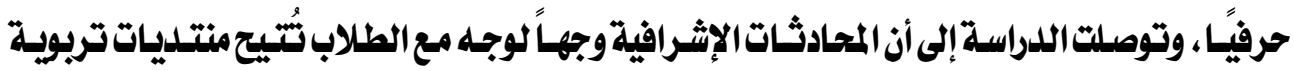
لإإثرافوالتحدثبشكل استباقي ورد الفعلوتعلمكيفية صنع القرارات الخاصة بالبحثوالملداخلات الرسميةوالتسهيلية للشرفين، وأظهرت النتائج أن صوت طالب الدكتوراه مسموعوله إسهامواضح فئي

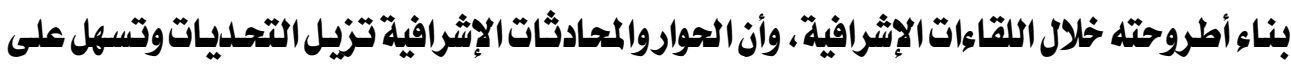
الشرفين الاستكافوبناء المعرفة والعلاقة الإيجابية مع الطلاب.

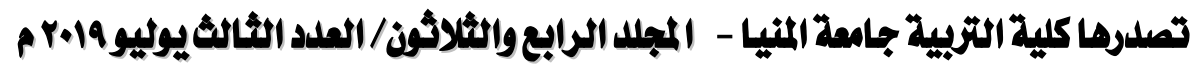
gamel_abdo59@yahoo.com

http://ms.minia.edu.eg/edu/journal.aspx 
دراسة كورنبه ولوفستروم وبيهـالتو (Cornér, Lofstrom, Pyhalto, 2017): بعنوان "

العلاقتات المتبـادلة بيز تصورات طلاب الدكتوراه للإثثراف والاحتراق النفسي"، هـفت إلى تحليـل جـودةونوعيـة إثـراف الـدكتوراه كمحلددات أساسية لإنجـاز أطروحة السدكتوراه، ومعرفة كيفية ارتباط نوعية وكفاءة الإثراف بخطر متزايلد أو منخفض للإرهاق أو الاحتراق النفسي أثناء دراسلة الدكتوراه، والتركيز على العلاقة المتبادلة بين العناصر المختلفة للإثراف والاحتراق، وكيفية فهم ارتباط أنثطة الإثراف والاحتراق وأثرها على إنجاز البحوث بيز طلاب الدكتوراه، واستخلدمت الدراسة المنهج الوصفي، معتمدة على استبيان عبر الإنترنت يتكوز من Y مفردة، طُبِق على عينة قوامها ( Y ) طالبًا بمرحلة الدكتوراه من ثلاث جامعات فنلندية في تخصصات العلوم الاجتماعية والفنـون والعلوم الإنسـانية والعلـوم الطبيعيـة، وتوصـلت الدراسلة إلى نتـائج أهمهـا : أن الطلاب يستفيدون من وجود الإثراف الجمـاعي في ظل وجـود إرهـاق واحتراق في نوعية الإثراف الفردي، وأظهرت التحليلات الإضـافية تبـاينًا في تصـورات الطلاب حسول أهميـة المصسادر المختلفة للدعم الإثرافي، وشلد الطلاب على دور المشرف الـرئيس، حيث كـان مستوى الرضـا عن الـدعم الإثرافي اللذي يتلقونه من الشرف الرئيس أكثر من المصادر الأخرى، كمـا أظهرت النتـائج ضعف الرضـا عن الإثراف بصفة عامة وقلة المساواة داخل مجتمع الباحثين، وأوصت اللدراسة بضرورة التركيز بشكل أكبر على نهع الإشر اف الجماعي لما له من مزايـا، والتأكيد على أهمية دور المشرف الرئيس في الدعم الإثرافي.

دراسـة ماسيك (Masek, 2017) : بعنـوان " إقامة علاقتات بـين المشرفين والطلاب من خـلال التوقعات المتبـادلـة : دراسـة من وجهة نظـر المشرفين"، هـدفت إلى تعرف كيفيـة إقامة علاقتات إشرافية جيدة بين الطلاب والمشرفين من وجهة نظر المشرفين من خلال التوقعات المتبادلة في الأدوار

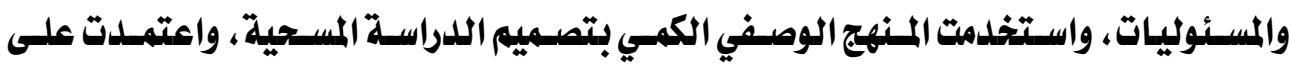
الاستبيان لجمع البيانات من المشرفين، طُبِق على عينة قوامها ( •1 ) مشرفًا على طلاب الدراسات العليا بجامعة توز حسين بماليزيـا، وتوصلت إلى مجموعة من النتـائج تشيـير إلى مستوى عـالٍ من التفاعل بين المشرفين والطلاب من وجهة نظر الشرفين، ووجود مناقشات جيدة واتصال واضح خلال

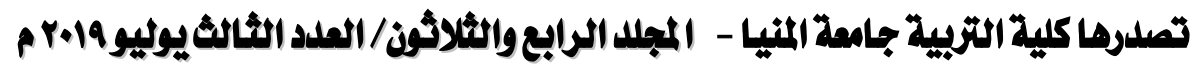
gamel_abdo59@yahoo.com

http://ms.minia.edu.eg/edu/journal.aspx 
الإثراف، وأكلدت أهمية إقامة علاقتات إثرافية جيلة بين المشرف والباحث؛ لحفز التواصل الجيل بينهما، وتوفير مناخ مناسب لتوقعات صريحة وواضحة ، كما أشارت النتائج إلى علدم وجود اختلاف كبير في مستويات التفاعل والتواصل من صفاروكبار المشرفين وهذا يستبعد عامل خبرة المشرفين في

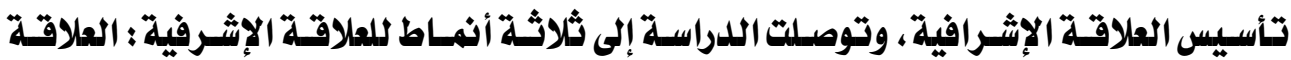

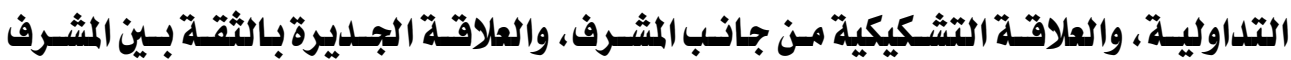
والطالب، ويمكن أن تمر العلاقة الإثرافية بـالأنماط الثلاثة وتتفير من نهط إلى آخر خلال مراحل البحث المختلفة. - الم

\section{تعاق عام على الدراسات السابقة، وبيان هوقع البحث العالي هنها:}

بـاستقراء ما تم عرضه من دراسات سابقة عربية وأجنبية يمكن استخلاص بعض الملاحظـات التي تتضمن أوجه الشبه والاختلاف بيز تلك الدراسـات والبحث الحسالي، ومدلى استفادته من هذه الدراسـات

$$
\text { وموقعه منها، يمكن رصد هله الملاحظات على النحو الآتي: }
$$

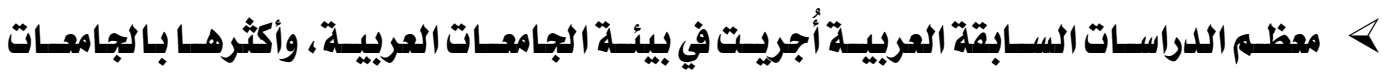
الفلسطينية مثل : دراسة( أبو دف، ץ.•r ) التي حاولت تقييم أداء الأستاذ الجامعي في مجال الإثراف العلمي بكليتي التربية جامعة الأقصى والجامعة الإسلامية، دراسة ( عسـاف، عا+r ) التي تناولت بـالإثراف الاكاديمي دراسة تقويمية بجامعة الأزهر والجامعة الإسلامية، وكليـات التربية بها خاصة،

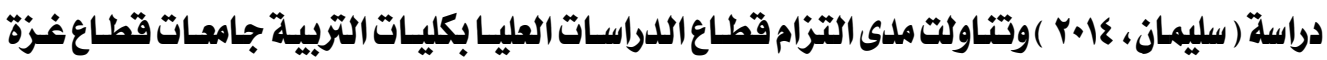
بعمايير اختيـار المشرفين على الرسائل العلمية، أو في الجامعات السعودية وكليات التربية مثل : دارسة

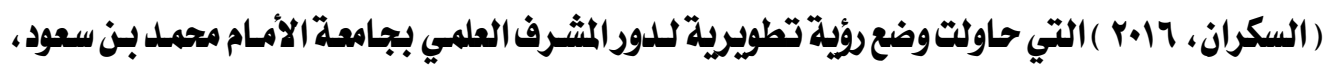
ودراسة ( سعيل، V V.r ) وتناولت واقع الإثراف العلمي بكلية التربية جامعة أم القرى، بينما كانت دراسة

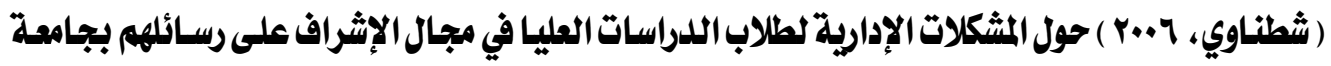

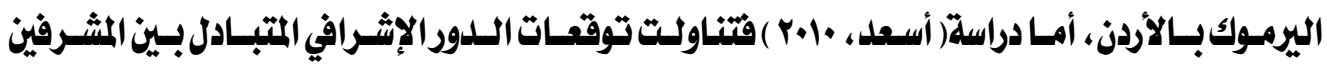
والباحثين بكلية التربية جامعة تعزبـاليمن، في حين كانت دراسة ( بكور، المب ) حول واقع الإثراف العلمي بكليات العلوم الإنسانية في جامعة دمشق بسوريا، أما دراسة ( زوليخة ومختارية، وا.r ) قتناولت معايير

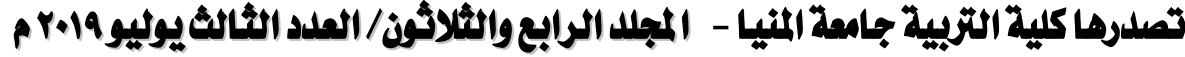




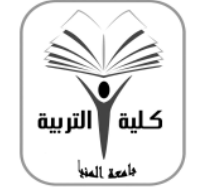

$$
\text { مجلة البحث في التربية وعلم النفس التربية - جامعة المنيا }
$$

كلية مُعتمدة من الهيئة القومية لشمان جودةالتعليم

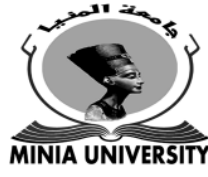

جودة الإثراف العلمي في علم النفس والتربية بجامعة وهران الجزائر. اللدراسـات على مستوى البيئـة المصرية كانت قليلة، وتناولـت الإثراف العلمي دراسلة تنظيريـة

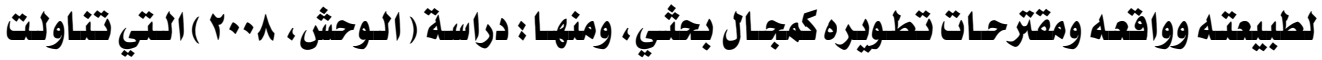
مشكلات الباحثات بكليات العلوم الإنسانية بجامعة الأزهر وكلية البنات جامعة عين شمس، ودراسلة

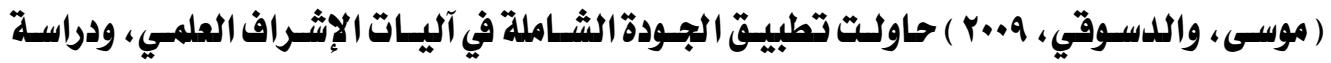

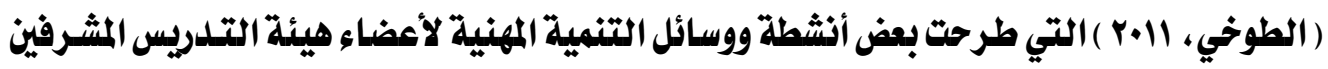

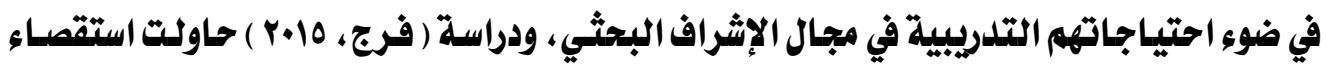
آراء أعضاء هيئة التدريس في كلية التربية جامعة بنها حول بعض المقترحات لتطوير الإشراف العلمي

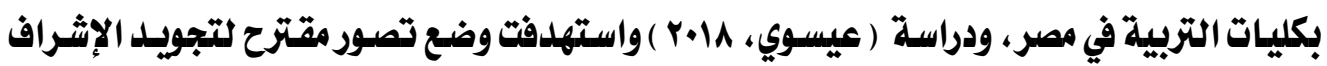

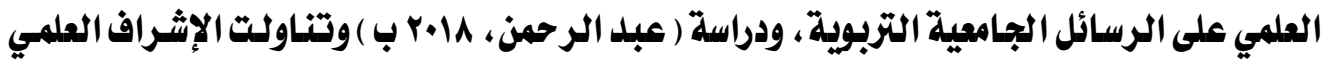
على رسائل الماجستير واللدكتوراه بكليسات التربية في مصر واقعه ووضعه الراهن ومقترحسات عامية لتطويره.

أما بالنسبة للدراسات الأجنبية فهنـاك اهتمام كبير من قبل البـاحثين بموضوع الإثراف العلمي أو البحثي على اختلاف مسمياته ومصطلحاته في هلذه اللدراسـات، وأهم النقاط التي تناولتهـا هلده

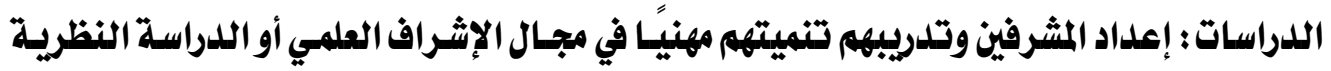

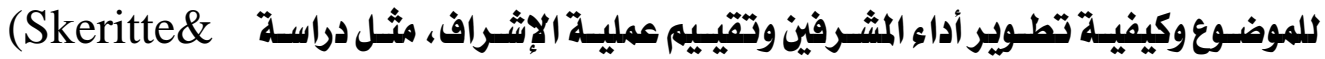
Roche, 2004) (Lee, 2007) (Grant, Hackney \& Edgar,2014) (Kiley, (2011، والعلاقة الإثرافية بين الشرفوالباحث والعوامل المؤثرة فيها وتصورات كل منها لهذه

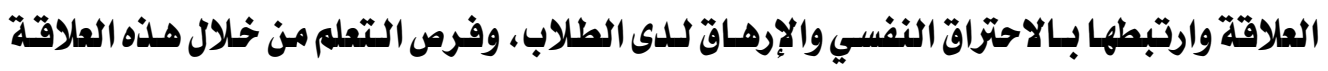

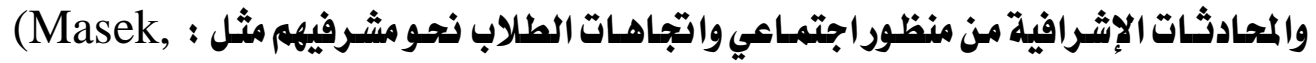
2017) (Cornér, Lofstrom, Pyhalto, 2017) (Tian and (Ali, Watson, and Dhingra, 2016)

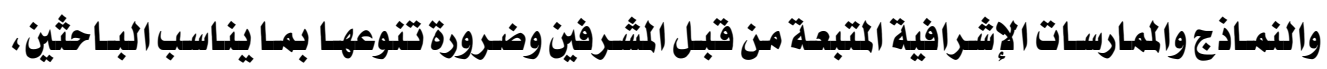


والتحليات التي تواجه جودة الإثراف، وتعزيز التميز الإشرافي مثل دراسة \& Nulty, Kiley, ) (Ana V. Baptista, Meyers,2008) (Abiddin, Hassan \& Ahmad, 2009) (2011، والاهتمام بقياس رضا الباحثين عن العلاقة الإثرافية والأساليب والنماذج الإثرافية المتبعة،

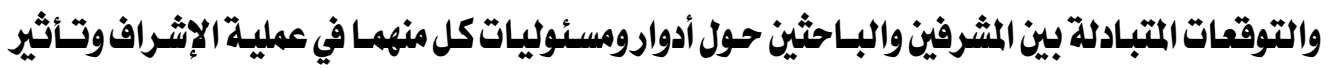

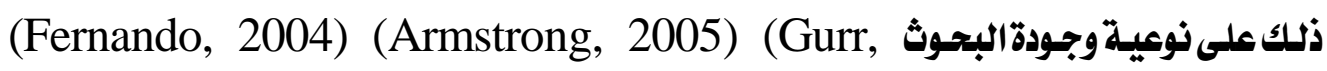

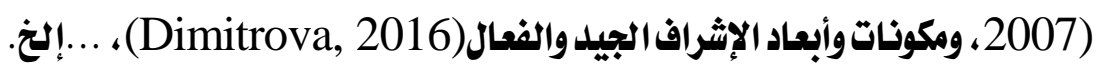
يُلاحظ خلو الدراسات العربية والاجنبية ( في حدود علم الباحث ومسحه للدراسات السابقة ) من وجود دراسات تناولت موضوع الإشراف العلمي من منظور مقارن، على الرغم من توصية معظم الدراسـات

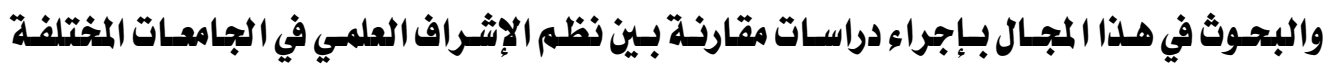
العربية والأجنبية وتعرف أوجه الشبه والاختلاف بينها والاستفادة منها في تطوير الإثراف العليكي

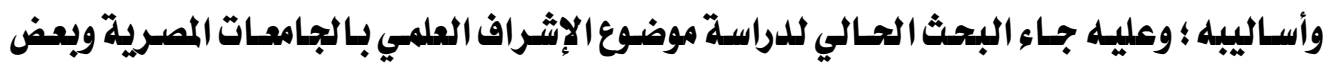
الجامعات الأجنبية المتميزة والرائدة في مجال البحث والإشراف العلمي من منظور مقارن ضمن مجال التعليم العالي المقارن كمجال للبحث في التربية المقارنة، وتلبية لتوصيات معظم البحوث والدالدراسات

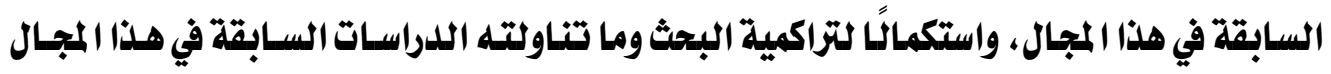

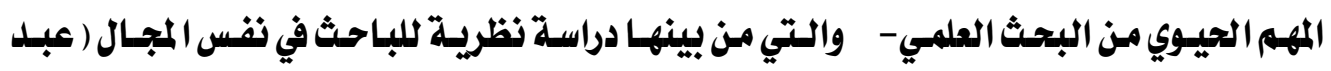

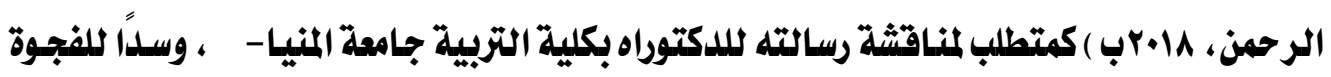

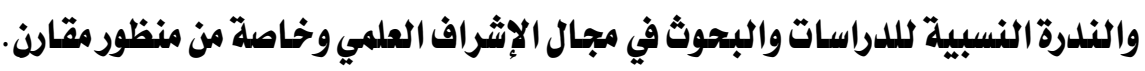

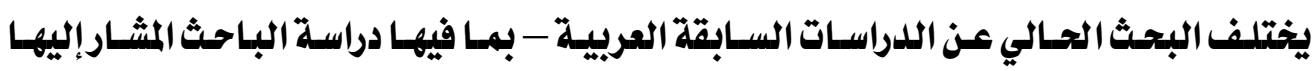

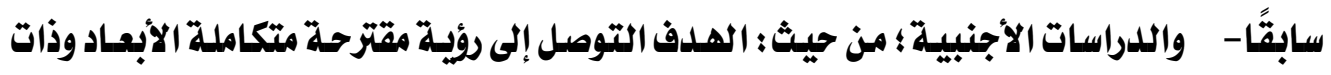
فلسفة ومنطلقات وأهلاف وإجراءات لتطوير الإثراف على الرسائل العلمية بالجامعات المصرية في ضوء واقعه ووضعه الراهن الخاص بـ ( إدارته وتنظيمه، ومعاييي اختيـار الثشرفين وتشكيل اللجـان الإثـرافية، وأدوارومسئوليات المثرفين والطلاب، وواقع العلاقـة الإشرافية بـين الأستاذ المشرف والطالب الباحث، والتنميـة المهنية لأعضـاء هيئلة التـدريس في مجال الإثراف العلمي )، ونتـائج พq\&

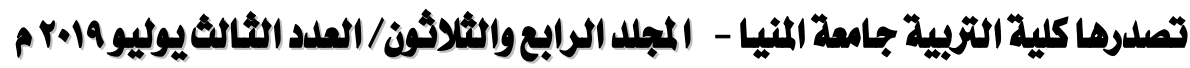
gamel_abdo59@yahoo.com

http://ms.minia.edu.eg/edu/journal.aspx 
التحليل المقارن لخبرات الجامعات الأجنبية موضع المقارنة بمـا يتناسب وطبيعة وثقافة المجتمع العلمي والسياسـات البحثيـة بـالجامعـات المصـرية، كمـا يختلف البحث الحسالي من حيث الحسلود الموضوعية والمكانية والزمانية، وطريقة المعالجة المنهجية ( المنهج المقارن وخطواته )، كمـا اعتمد البحث الحالي في تعضيد المشكلة وإثباتها بـالمقابلات الشخصية غير المقننة( المفتوحة )، وملاحظـات الواقع والتجارب الشخصية الميلانية في مجـال البحث العلمي بمر حلتي الماجستير والدكتوراه، وفي مجـال الإثـراف على طـلاب الماجسـتير كمضـو هيئة تـدريس بإحسلى كليـات التربيـة في الجامعـات المصـرية، كمـا أجسرى البحث تحليلًا وثائقيـا للتشريعات والسياسـات والقـوانين واللـوائح المنظمهة للإثراف على الرسائل العلمية المعمول بها خلال فترة إجـراء البحث بـالجامعات المصرية والأجنبية، كما اختلف المخرج النهائي ونتائج البحث الحسالي عن غيره من البحوث والدراسـات السـابقة؛ حيث قـلم رؤبــة تطويريـة مقتر حـة متكاملـة المحساوروالأبعـاد لتطـوير الإثـراف على الرسـائل العلميـة بالجامعات المصرية. > يتشابه البحث الحسالي مع الدراسـات السابقة في مجال البحث وموضهوعه وأهميته، وبعض محساور التأصيل النظري والمفـاهيمي لطبيعـة الإثـراف العلمي وأسسه وأبعـاده-وإن تفرد البحث الحسالي بالتنظير لطبيعة العلاقة الإشرافية أنواعها وضوابضها، وأنماط الأساليب الإثرافية وأنواعها، ومعايير جودة الإشراف العلمي واختيار المشرفين وتشكيل اللجان الإشرافية، ومقوماتومواصفات المشرف العلمي الفمال، وأدوارومسئوليات طرفي عملية الإثراف( المشرف والباحث )، وأسـاليب التنمية المهنية في

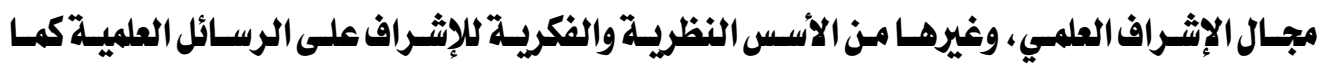
سيوضحها الإطار النظري المفاهيمي للبحث الحالي. > كان للاطلاع على الدراسـات السـابقة فائـلدة وجسلدوى كبيرة في تكوين تصـور لأبعـاد البحث الحسالي ومحاوره، وتحليد مشكلة البحث وحدوده، ومنهجيته وخطواته ، وتكوين الإطـار النظري، وتحليل واقع الإشراف العلمي، وبلورة الرؤية التطوبرية المقترحة. خطوات السير في البمث ( تخطيط بنية البمث وهماوره): في ضوء مشكلة البحث وأ هدا فه وحدوده ومنهجه ، سـار البحث وفق خطوات مثلت بنيته ومحاوره rqo

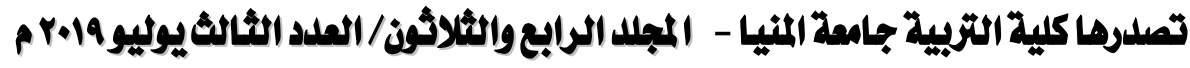
gamel_abdo59@yahoo.com

http://ms.minia.edu.eg/edu/journal.aspx 


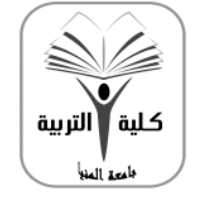

$$
\text { مجلة البحث في التربية وعلم النفس }
$$

كلية مُتملدة من الهيئة القوميلة لشمان جودة التمليم

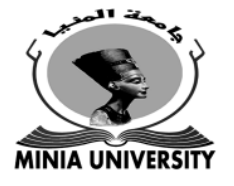

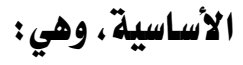

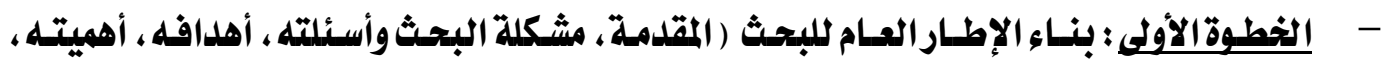
مصطلحاته، حلدوده، منهجه وخطواته، واللدراسـات السـابقة العربية والاجنبيية والتعليق عليها

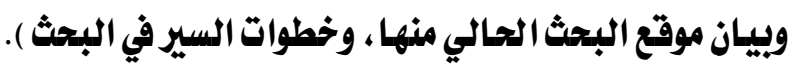

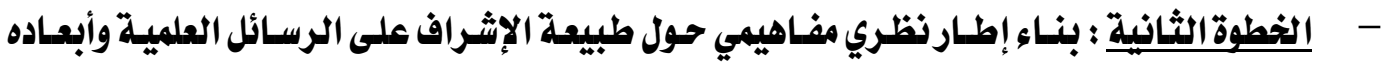
وأسسه النظرية والفكرية في الأدبيات التزبوية المحاصرة.

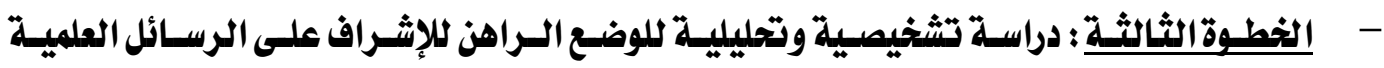
بالجامعات المصرية في ضوء محاور البحث وحدوده الموضوعية. - الخطوة الرابعة: د دراسة وصفية لأهم ملامح الإثراف العلمي بـالجامعات الأجنبية الثلاثة المختـارة في ضوء حلود البحث الموضوعية ومحاور المقارنة. الخطوة الخامسة : دراسة تحليلية مقارنة لأوجه الشبه والاختلاف بين الجامعات الأجنبية موضع

المقارنة والجامعات المصرية في مجال الإثراف العلمي، واستخلاص أوجه الاستفادة منها.

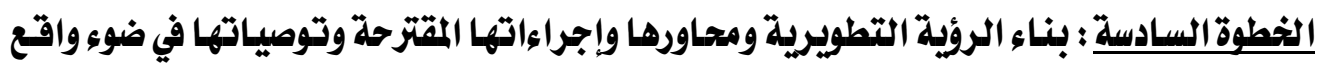
الإثراف العلمي بالجامعات المصرية ووضعه الراهن، والاستفادة من خببرات الجامعات الأجنبيـة المختارة، ثم تقليهم مجموعة من الدراسات والبحوث المستقبلية في مجال الإشراف العلمي. الحور الثاني- الإشراف على الرسائل العلمية "إطار نظري هفاهيهي":

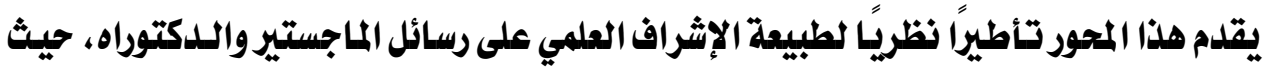

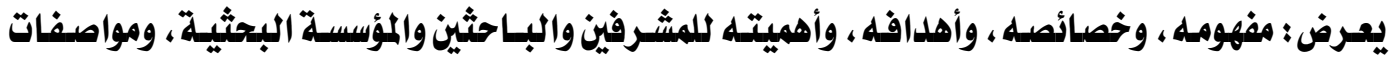
ومقومات الشرف العلمي الفمال، ومعايير جودة اختياره، وأدوارومسئوليات الشرف والطالب، وأنماط وأساليب الإشراف العلمي، وضوابط العلاقة الإشرافية، والتنمية المهنية في مجال الإثراف العلمي، وذلك الكالك على النحو الآتي: - التي

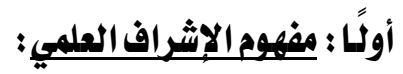
تعلد عملية الإشراف العلمي أحل أهم عمليات إعلاد الرسائل العلمية ( الماجستير والـدكتوراه ) في ry

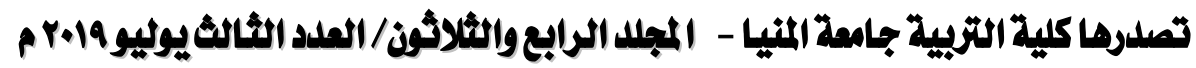
gamel_abdo59@yahoo.com http://ms.minia.edu.eg/edu/journal.aspx 
مرحلة الدراسات العليا الجامعية، فالمشرف العلمي هو المسئول الاكبر عن تشكيل وتكوين عقلية البـاحثين ورؤيتهم البحثية من خلال التتلمتذ على يلده كأستاذ وباحث متمرس في مجال تخصصه، ومن خلال مطالعة الباحث وفحصه للدراسات السابقة - المشار إليها آنفًا- تعلد مفاهييم الإثراف العلمي ومسمياته ما بين الإثراف الاكاديمي أو الإثراف على طلاب الدراسات العليا أو الإثراف البحثي، أو الإثراف على البحوث، الإشراف على الدكتوراه، أو الإشراف على بحوث الدرجة العليا، كما لا يوجد تعريف واحد متفق عليه للإثشراف العلمي، ولكن هناك آراء ووجهات نظر متعددة ومتنوعة بتعدد وتنوعزوايـا النظر إلى هذا المصطلح، حيث تزخر الأدبيات التربوية العربية والأجنبية بمنظورات متنوعة لتعريـف الإثراف على الرسـائل العلمية الجامعية، فهناك تعريفات من المنظور: الإداري والفني، والتدريسي التدريبي ( تلملةة )، والمهني، والمنظومي. فمن المنظور الإداري والفني تتفق بعض الأدبيات والدراسات حول تعريف الإشراف العلمي بـأنه : العملية الإدارية والفنية التي يقوم بموجبها عضو هيئة التدريس أو أكثر بـالجامعة أو أحلد أصحاب الخبرة من خارج الجامعة بتوجيه وإرثاد الطالب الباحث إسناداً من القسيم المختص وعلى مواققة مجلس الكلية

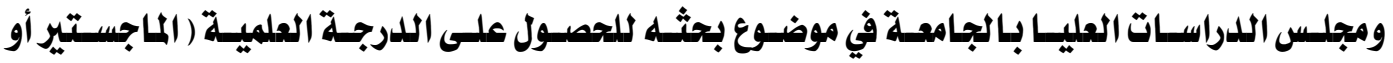
الدكتوراه )، ويبدأ الإثراف من بلداية التكليف وقيد أو تسجيل الطالب وينتهي بـانتهاء الطالب من إعداد رسـالته وتجهيزهـا للمناقشة حتى الحصول على اللدرجة، ولن يتحقق ذلك إلا من خلال وجـود شخصين

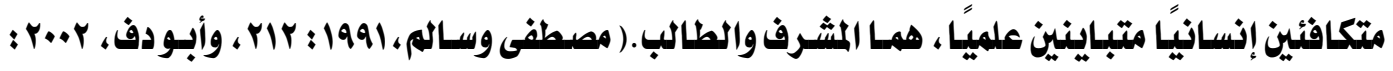

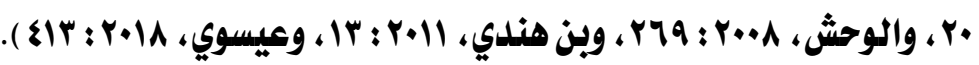
ومن المنظور التدريسي والتدريبي، هنـاك من يـرى أن الإثراف العلمي شكل من أشكال التلدريب والتدربس والتعلم والتلملة، تتم تحت علاقة هرمية وغير أحادية الاتجـاه لنقل المعرفة من المشرفين إلى طلاب

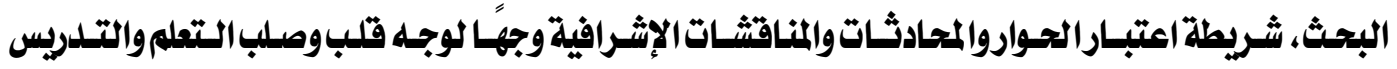

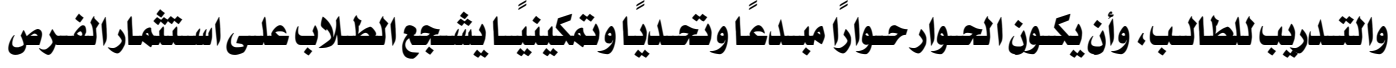

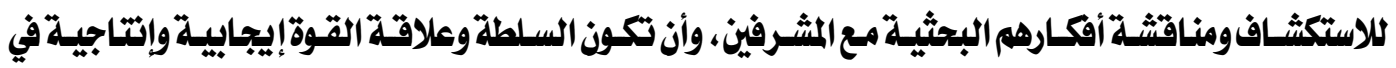

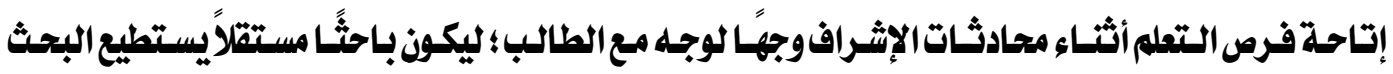
واكتساب المعرفة الاكاديمية والمهارات الشخصية (654 -653 : Tian , Singhasiri, 2016). rTV

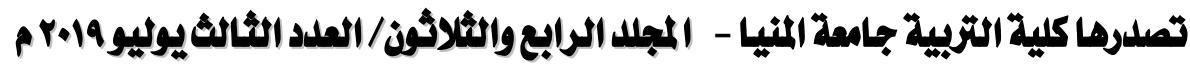
gamel_abdo59@yahoo.com

http://ms.minia.edu.eg/edu/journal.aspx 
ومن المنظور ذاته يُعرف زاهو Zaho (2002) الإشراف العلمي بـأنه مساعلة الباحثين على

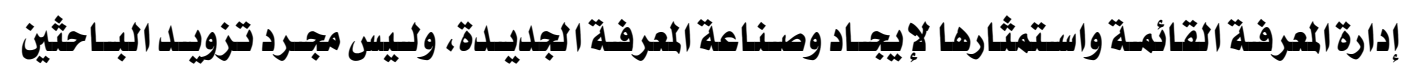
بمجموعة من المهارات والأدوات البحثية، فهو عملية رعايـة وتعزيـز التصلم والبحث والاتصـال على أعلى

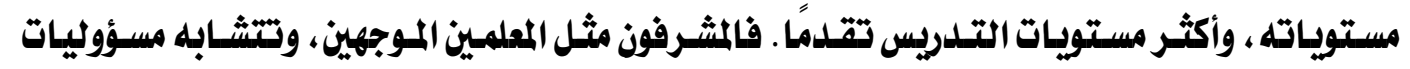
الشرفين والمعلمين والموجهين إلى حلد بير في الإثراف والدعم والتعهل بالرعاية للطلاب والباحثين والعمل على تقدم مستوا هم دوذ السيطرة عليهه، فهناك فروق بين الإثراف والرقابة، ولعل أهمها أن الإثراف دعم وتوجيه وإرشاد، بينمـا الرقابـة تحمل معنى السيطرةوالقوة \&indgreen, Palmer, Vanhamme Beverland, 2003: 147)

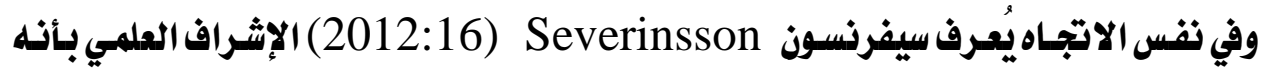
المستوى الاكثر تقدمًا في التلدريس، فهو عبارة عن علاقة ائتمانية يساعد من خلاوهـا المشرف الاككاديمي في تعزيز تعلم الطالب في ظل علاقة طيبة تجمعهم تقثل العامل الأساسي في نجاح أو فثل الطالب الباحث للوصول إلى درجة الماجستير أو اللكتوراه، كما أنه عملية معقدة تقوم على أسـاس التفاعل بـين طلاب الدراسـات

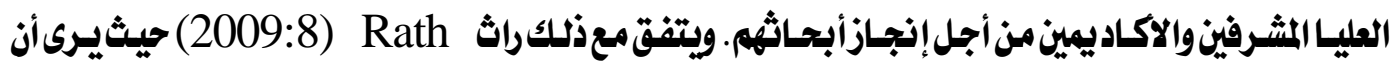
الإشراف العلمي جانبًا من جوانب التدربس الأساسية يهتم ببنـائ قدرات الطلاب المعرفية كمهارة بحثية رئيسة،

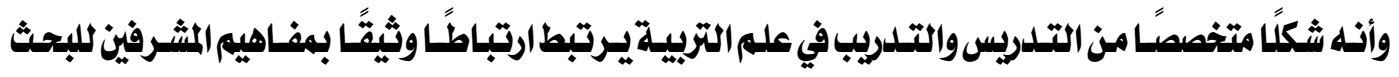
ومصطلحات التوجيه واللدعم والمساندة.

وفي السيـاق التلدريسي التعليمي أيضًا يُعرف الإثـراف العلمي بـأنه عمليـة تعليميـة وتنمويـة مترابطة تجـري في إطـار علاقة إشـرافية مهنية وأكاديميلة واجتماعيـة وأخلاقية منضبطة بـين المشرف والطالب الباحث من أجل إنجازالرسالة العلمية على أكمل وجه. \&an Rensburg, Mayers \&

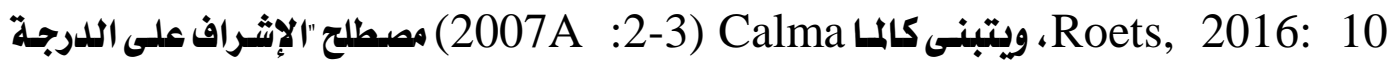
البحثية العليـا" ويعرفه بـأذه الإثراف الاككاديمي لأعضـاء هيئة التـلدريس على طلاب الدراسـات العليـا الـذين يقوموذ بالبحث لنيل درجـتي الماجستير والدكتوراه، ويتمثل في عملية تهيئة البيئة التعليميـة والبحثية المناسبة لمسـاعلدة هـولاء الطلاب على إكمال أبحاثهم. كمـا يـرى أن الإثراف العلمي يهلدف في

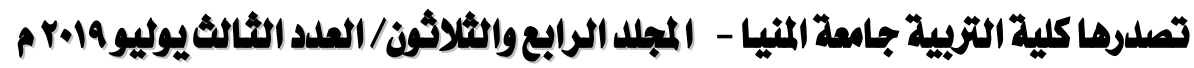
gamel_abdo59@yahoo.com

http://ms.minia.edu.eg/edu/journal.aspx 


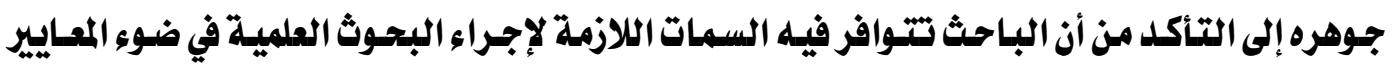
العلمية المقبولة، والتـأكل كذلك من أن البـاحث يتلقى الدعم الـلازم، ومسـاعدة الخبراء ( المشرفين ) لكي يكمل رسالته أو أطروحته بنجاح. (Calma, 2007b:91 - (C2). ومن زوايـة أخرىى يُنظـر لإإثـراف العلمي على أنه ممارسلة مهنيـة ؛ حيث إن المشرف العلمي هـو الشخص اللني يجب أن يكون ممارسيا مهنيًا متأملًا وناقدًا لعمل الطالب وموجهًا له ، ويجب أن يكوز حاسئا في أمرين : الإيمان بـأهمية هذه المهنة، وممارسة أدوارومسئوليات تلك المهنة بشكل فمـال، كما يجب أن يكوز على دراية كاملة بـأن الإشراف كمهنة ليست مجـرد امتداد عمل التلدريس ولكن أيضًا وسيلة لتدريب

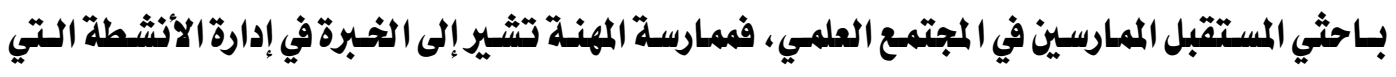
(Calama, تتعلق بهله المهنة وتشكل الدراية والمعرفة للممارس بما يجب القيام به من أدواروممارسات .2007b: 91-92).

وفي سياق منظومية الإشراف العلمي وأنه نظام لله عناصر تأخذ بعين الاعتبار الطالب، المشرف ،

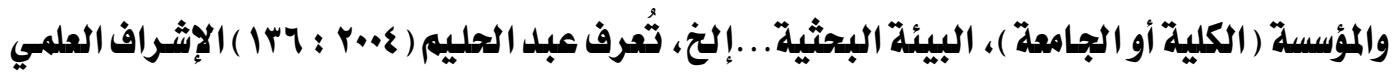
بـأنه : نظام يقوم على ثلاثة عناصر أساسية هي : الطالب الباحث، والأستاذ المشرف، وموضوع البحث، وأنه عملية توجيهيه بين طرفيين الإثراف لمعالجة موضوع البحث، ومن ثم فهو يحتاج إلى علاقة إشرافية ومهنية متميـةة بـين الأسـاتدة المشرفين ( المشـرف والباحث ) ، حيث يكون الأستاذ المشرف موجهًا ومرشدًا ومشجقًا على المنافسة والبحث والابتكار، ويكوز لدى الطالب قابلية للتوجيه والتعلم، ويتم في ظل هـده العلاقة إنجاز الرسـائل العلميـة. ولعل هـذا التعريف يجمع بـين منظومية الإثـراف العلمي، وكونه مهنة تدريسية وتدريبية وتعليمية.

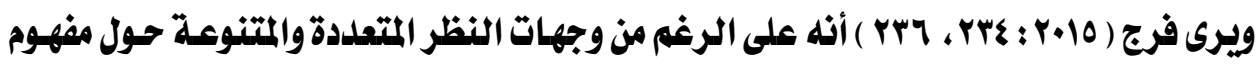
وطبيعـة الإثـراف العلمي، وتعـلد مصطلحاته ومسيـياته ، إلا أنها تتضـمن في جوهرهـا عمليـة توجيـه ومسـاعدة من قبـل أعضـاء هيئسة التـلدريس المشـرفين ذوي الخبرة لطلاب الدراسـات العليـا في مجـال مـا ؛ فالإثراف العلمي ممارسات علمية وعملية للدراسة نقطة بحثية ما ؛ بغرض الوصول إلى حقائق جديـلـة من قبل الباحث تحت رعايـة ومسئولية متخصص ومتمرس ( مشرف أو أكثر ) في المجـال العلمي الملدروس، وفي r.

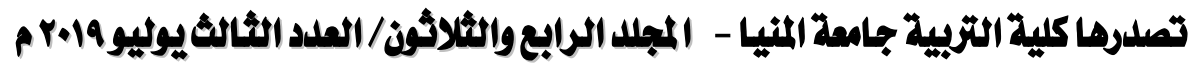
gamel_abdo59@yahoo.com

http://ms.minia.edu.eg/edu/journal.aspx 


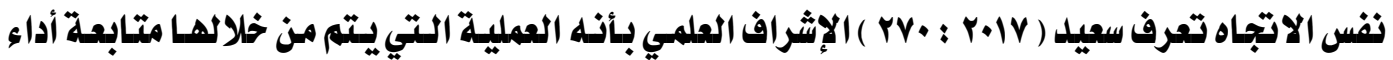
طلاب اللدراسات العليا بمر حلتي الماجستير والدكتوراه في رسائلهم، والعمل على تطوير مهاراتهم البحثية وتذليل العقبات التي ربما تعوقهم علميًا عن إنجاز رسائلهم، وذلك من قبل أحلد الأساتذة المتخصصين في المجـال الـذي يتبعه الطالب الباحث. فالإثـراف العلمي إرثـاد وتوجيـه للباحث لإنتـاج بحث نـوعي وأطروحة عالية الجـودة، والانتهـاء منها في الوقت المناسب، ونشرها في المجتمع العلمي، وأيضـا إعداد (Abdallah, Hillerich, Romero, Topp الباحث لمهنة المستقبل ذات الصلة بتخصصه البحثي .\& Wnuk, 2010: 1)

ومما سبق يتضح أنه على الـرغم من تعلد مصطلحات الإثراف العلمي ومسمياته ، إلا أنها في

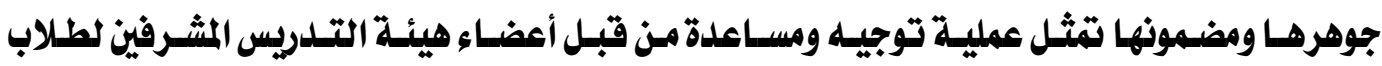
الدراسات العليا بـاحثي الماجستير والدكتوراه من أجل إنجـاز الرسـائل العلمية في التخصصسات الجامعية المختلفة، والبحث الحالي يتبنى مصطلح الإثراف العلمي من بـين المصطلحات والمسهيات المتعددة لعملية الإثراف على طلاب الدراسـات العليـا ورسـائلهم العلمية، لأنه أكثر عموميلة وانتشـارًا وتدوانًا وشيوعًا ويتبادر إلى الإذهان دائمًا المعنى المقصود بله، كما أن كلمة علمي في وصف الإثراف أدق، حيث يُبنى الإثراف من أجل إنجاز الرسالة على أسس علمية وخطوات منهجية، كما أن هذا المصطلح يشمل الإثراف والتوجيه في المجـال المعرفي لموضـوع الرسـالة من الناحيـة العلميـة، وكيفيـة معالجتهله بطريقة إجرائيـة وخطوات

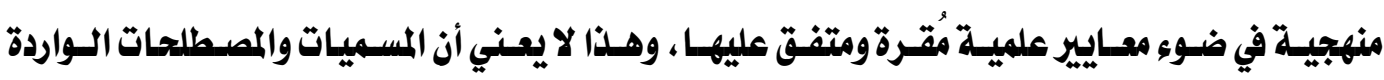
بـالدراسات والبحوث خاطئة أو لا يجمعها جامع، بل هي تكاد تكون متردافة وجميعها تسير على القاعلدة الأصولية المعروفة "لا مشاحة في المصطلح". وباستقراء المنظورات السابقة لتعريف الإشراف العلمي، يتضح أنه عملية إدارية فنية تدريسية تدربيية مهنية أو منظومة فرعية من نظام البحث العلمي لله أركانه وعناصره الأساسية المتفاعلة من أجل

$$
\text { إنجازرسالة علمية جيدة، وهذه العناصر كالآتي: }
$$

ا- الطالب البياحث: اللذي ينبفي أن يمتلك قدرات ومهارات واستعدادت بحثية تؤهله لإنجاز الرسالة على الوجه المطلوب، وعلى وعي بسأدواره ومسئولياته خلال مراحل البحث المختلفة، وأنه المسئول $r v$.

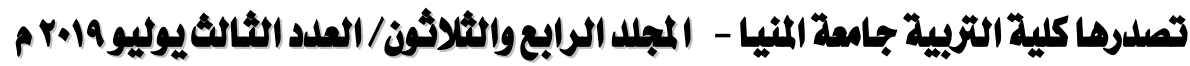
gamel_abdo59@yahoo.com

http://ms.minia.edu.eg/edu/journal.aspx 


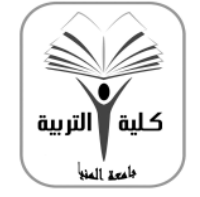

$$
\text { مجلة البحث في التربية وعلم النفس التربية - جامعة المنيا }
$$

كلية مُعتمدة من الهيئة القوميلة لشمان جودةالتعليم

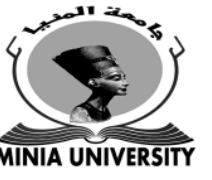

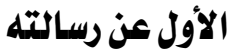

r- مشرف أو أكثر : من أعضاء هيئة التدريس أو المختصين من خارج الجامعة ذوي الخبرة العلمية والمهنية في مجال البحث والإثراف العلمي، ولديهم القدرةوالوقت الكافي لتوجيه ومساندة الطالب وتقاسم مسئولية إنجاز الرسالة العلمية.

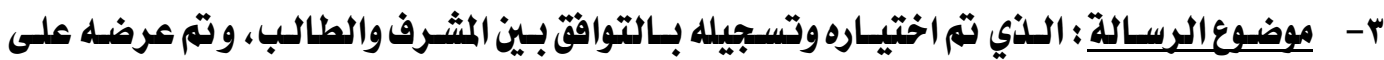
السيمنار العلمي للقسم المختص والموافقة عليه في مجلس القسم والكلية وا لجامعة. ؟- عمليات الإشراف العلمي : من الدعم والتوجيه والمتابعة التي تقثل صميه العمل الإثرافي. 0- العلاقة الإشرافية: وهي قلب ولب عملية الإثراف ومفتاح نجاحه، وينبفي أن تكون علاقة علمية مهنية اجتماعية أخلاقية إنسانية بـين الباحث والمشرف تنظهها أسس وقواعلدواضحة وتحكمها ضوابط حازمة وصارمة لإنجاز موضوع البحث في جوومناخ علمي وإنساني مناسب.

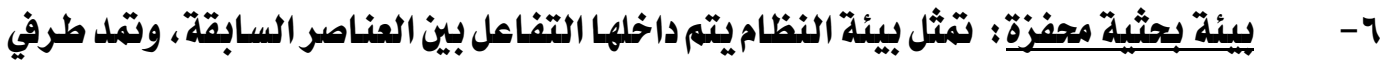
الإثراف ( المشرف والباحث ) بالموارد والمرافق البحثية اللازمة لإنجاز الرسالة.

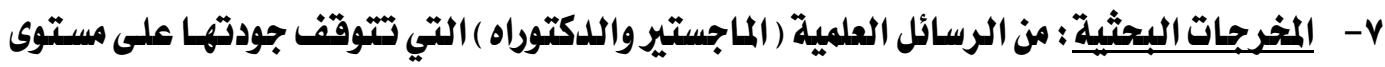
جودة الإشراف العلمي وعناصر وعمليات وأداء المنظومة البحثية في الدراسات العليا.

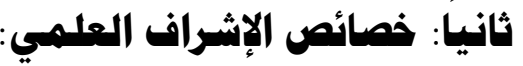

الإثراف على الرسائل العلمية ليس مجرد عمل روتيني إداري، بل إنه بالأساس عمل علمي فني لا

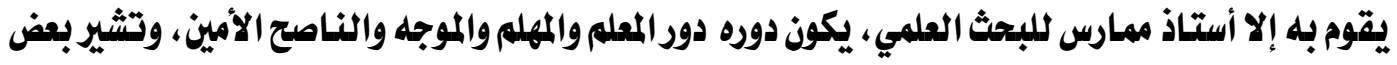

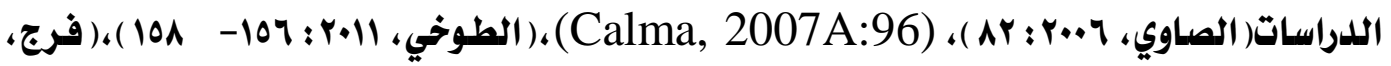

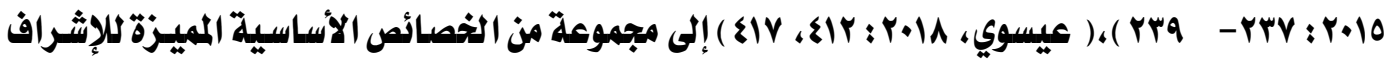

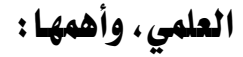
- - أنه عملية صعية ومعقدة توثر فيها عوامل ومتفيرات متعلدة: وتزداد صعوبتها وتعقدها في ظل التقلم العلمي والمعرفي والتكنولوجي المتلاحق والتحسليات والتفيرات التي تفرضها العولمة وثورة المرفة والمتفيرات الاقتصادية والاجتماعية؛ مما يجعل الإشرف العلمي عملية مركبة وصعبة وتتأثر rVI

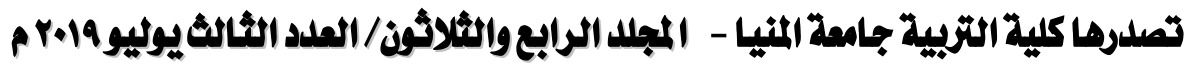
gamel_abd059@yahoo.com

http://ms.minia.edu.eg/edu/journal.aspx 
بعليد من المتفيرات المتداخلة، فهناك متفيرات مرتبطة مباشرة بجودة الإثراف وتؤثر على حسن سير العملية الإشرافية وهي متفيرات تتعلق بـالمؤسسة البحثية ودعمها للبحث والباحثين، ومتفيرت تتعلق بـالثـرف وخبراته ومهاراتـه البحثيـة ومواصـفاته الأخلاقيـة والاجتماعيـة، ومتفيرات مرتبطـة بالباحث وقدراته ومهاراته البحثية والاجتماعية، وقيمه الأخلاقية. عمليـة متعـدة الجوانب ومتشـابكة العنـاصـر : فليس من السهل الفصل بـين عنـاصـرها ومكوناتهـا ( منظومة متكاملة ) علمية وعملية تعليمية تقلدم للطالب حقائق ومفاهيب ومعلومات جليلدة وتكسبه مهارات التفكير والبحث، كما أن صعوبتها تظهر من ناحية أخرى في تعلدد مسئولية المشرف المباشرة عن الباحث، والعلاقة الإشرافية بينهما ، فالالتزامات كثيرة من قبل الششرف تجاه الطالب تتمثل في توفير الوقت الكـافي للإجابـة عن أسئلته ، والمشـاركة بـالرأي والمشـورة في اختيـار موضـوع البحث ومعالجته حتى عرضه ومناقشته أمام لجنة المناقشة والحكم والدفاع عنه حتى حصول الباحث على اللدرجة العلمية.

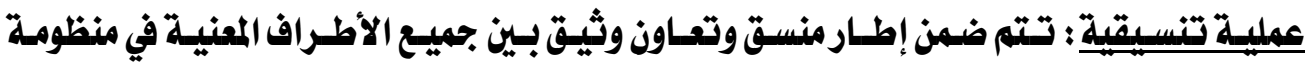
الدراسات العليا ( المشرف أو المشرفيز والباحث والدراسات العليا والكلية والأقسام العلمية. ..إلخ ). - عملية استشـارية: لأنها تثلدم استشارات ومقتزحات وبلدائل للطلاب والبـاحثين خلال مراحل البحث المختلة. عملية علمية وفنية وأخلاقية: وذلك في آذ واحد فهي تحتاج إلى مشرف مقتلدروطالب تتوافر لليـهـ مجموعة من القدرات والكفايـات والمهارات ؛ ممـا يتيح لـه التفاعل والتشـاوروتتحقيق الإنجاز على المستوى المطلوب. - الماب.

عملية إنسانبة تفاعلية وتعاونية ؛ بين الطالب الباحث والأستاذ المشرف، وينبفي أن تتسم بـالمرونة والاستمرارية في التوجيه والنصـح حتى الانتهاء من الرسـالة، وقبـل المنـاقشّة وبعدها حتى منتح الدرجة العلمية. ومن ثميتضح أن الإشراف على الرسـائل العلمية وتحمل مسئولية توجيه الباحثوإرشـاده ليسبـالأمر

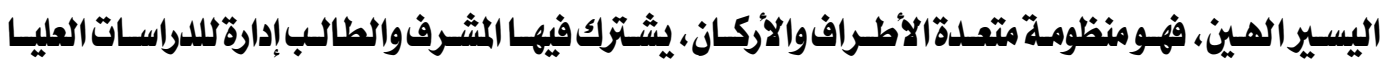
rVT

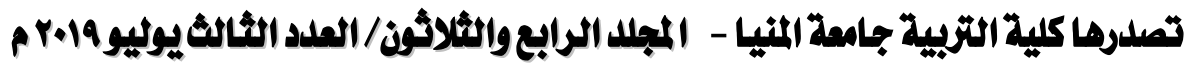
gamel_abdo59@yahoo.com http://ms.minia.edu.eg/edu/journal.aspx 
بالجامعة والكلية وأقسامها العلمية، ومن ثم فإن تطويرها يحتاج نهجًا يشارك فيه جميع أطراف النظام العلمي والبحثي لإحداث تجويلد وتحسين في الإثراف العلمي وعناصره، ومن ثم تحسين وتجويدل مخرجاته من الرسائل العلمية.

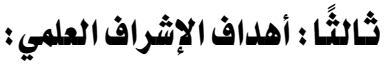
تتعلد وتتوع أهداف الإثراف على الرسائل العلمية، يمكن إيجازوبلورة بعض أهدافه في الآتي

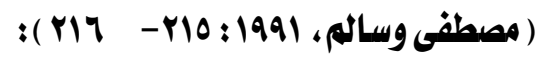

ا- توجيه الطالب الباحث للاطلاع بمهمة البحث العلمي، وإرشـاده إلى المسـار السليم للبحث وتدليل

$$
\text { الصعوبـات التي تعوقها }
$$

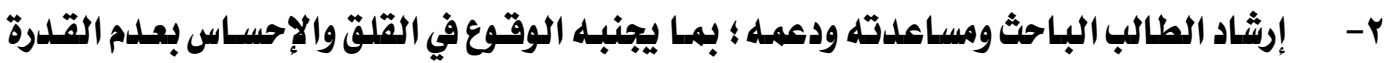
على إنجـازمـا يُتوقع منهه ، وذلك بتعليمه طريقة الإنجـاز السليمة، وتقديم الخبرات والمعارف والمهارات اللازمهة لإنجساز البحث، وبـث روح الثقة في نفسه، وخاصة فيمـا يتصل بقدرته على المعالجة الصحيحة لقضايا البحث؛ بما يشيع في روحه الطمأنينة والثقة. ץ- تقويه أفكار الطالب الباحث، ورعايته، وإبراز مواهبله ، وتوجيهل وإرثـاده إلى الأفضل، وتدريبه على استثمار كل الفرص والإمكانات المتاحة في سبيل إنجاز بحثه وتقدمه. ع-رعاية وبناء شخصية الباحث العلمية والأخلاقية، وتلدرببه على الاستقالال بـالرأي بموضـوعية

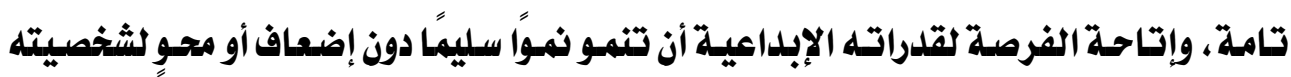

$$
\text { البحثية. }
$$

وباستقراء الأهداف السابقة، يتضح أن جميعها تدور حول الهدف الرئيس من الإثراف العلمي على الباحثين ألاوهو تقدليم التوجيه واللدعم والمسـاندة والإرشـاد من أجل إنتـاج مخرج بحثي متميز، وإعداد باحث واعد في المستقبل. رابعا: أههية الإشراف العلهي لاعمشرفين والباحثين والمؤسسة البشثية: للإثثـراف العلمي أهميـة كبيرة للبـاحثين كـدمه ومسـاندة وتوجيـه لإنجـاز رسـائلهم العلميـة، وللمشرفين كتنمية مهنية وصقل خبراتهم البحثية والإثرافية، ليس هذا فحسب فالإثراف العلمي المتميز rVT

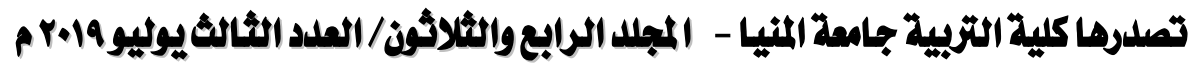
gamel_abdo59@yahoo.com http://ms.minia.edu.eg/edu/journal.aspx 
له أهيته بـالنسبة للمؤسسة البحثية الجامعية؛ لكونه الأسـاس في تجويـل البحث العلمي وإعداد جيل متميز من الباحثين الواعلين في المستقبل، وهذا يسهم في تقلدم الجامعة ومرتبتهـا في التصنيفات العالية، ويمكن بيسان أهية الإشراف العلمي للباحثين والشرفيز والمؤسسة البحثية الجامعية على النحو الآتي: ا- أهمية الاشثراف العلمي للطلاب البياحثين:

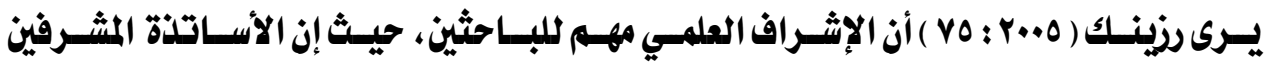
الناصحين(Mentors) غالبًا ما يلعبوز دورًا مهمًا في تثثتيف وتعليم وتدريب علمـاء المستقتبل الطلاب البـاحثين )، من خلال إمـلدادهم بـالمهـارات وا الخـبرات اللازمهة لإجـراء وكتابـة البحـوث والرسـائل العلميـة الجيـلة، وكيف يحصلوز على التمويل المناسب، وكيف يواصلون أبحاثهم للبقـاء في المجـال الاكساديمي والجامعي، وذلك عن طريق الإرشاد والإثراف والتوجيه العلمي السلديل من هؤلاء الأسـاتذة لطلابهيم عن كثب ووجها لوجه وخطوة بخطوة، وهذه العلاقة الإثرافية الناصحة الراشدة تثثل بواكير علماء جدد. كما يُعد الإشراف العلمي ذا أهمية خاصة للباحث المبتدئ ؛ حيث يحتاج الطالب/ الباحث لمشرف يثق فيه، ويشاركه التفكير، ويرغب في نصحه وإرشـاده إزاء بجثه والسير فيـه، فالمشرف هو المرثـد والموجـه لعمل الطالب، والملدقق للتأكلد من سلامة ودقة الإجراءات البحثثية فنيًا وعلميًا من جانب، وملدى التزام الطالب

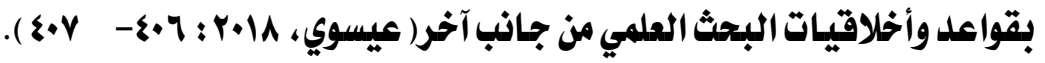
فمن المقرر في أصول التأليف والبحث العلمي أن بلوغ مرتبة الاستواء المنهجي محوج إلى مرثلد وموجّه ؛ ذلك أن مرحلة الطلب أو التحصيل العلمي هي معاناة وألم واحتراق معرفيّ، ولا بلد لعملية الاحتراق العلمي من مسـد يتـولى جوانبها العلميلة والأخلاقيـة؛ ممـا يستوجب تخصيص مشـرف لكل طالب بـاحث لأسباب متعددة: علدم استفناء الطالب الباحث مهما علا كمبه وارتفع نجمه عن المشرف ؛ نظراً لطبيعة المعرفة العلمية التراكمية والتواصل المنهجي والتسليد المعرفي، وحاجة الباحث إلى خبير يتولى الإثـراف على البناء المنهجي للبحث ؛ لأن غياب المنهجية المحكمة في التأليف والتصنيف يفضي إلى انهيار البحث، واستناداً إلى طبيعة البحث المعقدة والشائكة والوعرة ؛ كان لزاماً على كل بـاحث عن الحقيقة العلمية أن

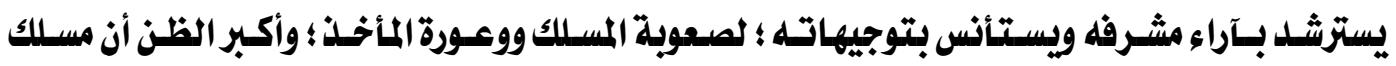
التحصيل المنفرد الحر قدل يفضي إلى مزالق كثيرة، وانحرافات جسيمة ( علدمان، الـr ؛ r- r ). 


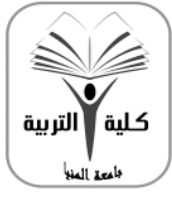

\author{
مجالة البجث في التزبية ومام النفس \\ كاية التزبية - جامعة المثيا \\ كالية مُتملدة من الميئة القومية لضمان جودة التمبيم
}

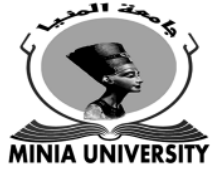

وعليه مسّت حاجة الباحث العلمي المبتـلئئ في مرحلة اللدراسـات العليـا إلى وجـود مشرف ومرشيد

علمي وروحي يتولى توجيهه ومساعدته في إنجاز رسالته ، ويمكن إجمال أهمية الإشراف العلمي للبـاحثين

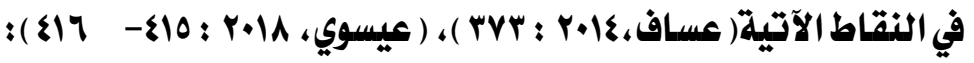
- إكساب الطلاب مهارات البحث العلمي وطرائقه وأساليبه ومنهجياته المختلفة من خلال إرشـاد وتوجيه المشرفين ودعمهم ومساندتهم طوال رحلة البحث ومراحله وفي جميع جوانبه. - تدريب الطلاب على التعلم الذاتي وتعرف نقاط قوتهم وضعفهم في مجال البحث، واستثماروتطبيق ما تعلموه من مهارات ومعارف وكفايات بحثية خلال مرحلة الدراسات العليا. - بث روح الثقة في النفس للدى الطلاب، وتشجيعهم على التعلم والإنجازبطريقة علمية مرنة مقننة في ظل علاقة إشرافية جيدة بين المشرف والباحث. - مسـاعدة الطلاب على إنهاء رسيائلهم العلميـة في الوقت المناسب وبـالشكل المطلـوب في ضوي معـايير الجامعة والكلية، ومعايير جودة البحث العلمي الرصين. - تدربب الطلاب على الالتزام بقواعد البحث العلمي السلمية، وتنمية أخلاقياته القويمة وضهوابطه العلمية للديهم.

- تكوين شخصية الباحث العلمية والأخلاقية كنمـوذج يحتـلى في المستقبل، وإعلداده للعمل والحصول على وظيفة مستقبيًا في نطاق تخصصه. r- أهمية الإشراف العلمي لأعضاي هيئة التدريس المشرفين: ويمكن إجمال أهمية الإشراف العلمي لأعضاء هيئة التدريس المشرفين في ضوء مـا أشـارت إليه

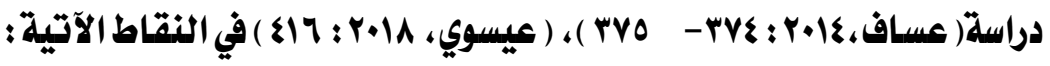
- زيسادة حصيلة المشرفين المعرفية وخبرتهم البحثية من خلال الإثراف على موضوعات ومجـالات بحثية متنوعة لطابهه ، فيثير هذا لليهيم أفكارًا وتوجهات بحثية جليلدة. - يحقق الإثراف على الرسائل العلمية لأعضاء هيئة التدريس نوعًا من الرضـا والتحفيز ؛ نتيجة دعم الطلاب ومساعدتهم في إنجاز رسائلهم على الوجه المأمول. - يعطي الإشراف على الرسائل العلمية المتميـزة لأعضساء هيئة التـلدريس سمعة وشهرة مهنيـة في المجسال rvo

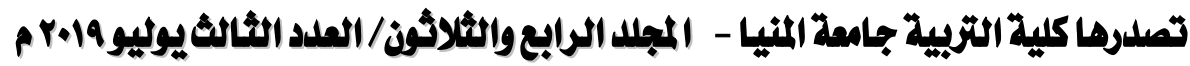
gamel_abdo59@yahoo.com

http://ms.minia.edu.eg/edu/journal.aspx 


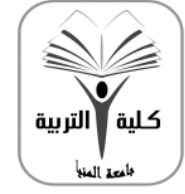

$$
\text { مجلة البعث في التربية وعلم النفس التربية - جامعة المنيا }
$$

كلية مُعتمدة من الهيئة القومية لشمان جودةالتعليم

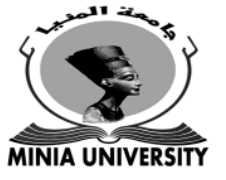

$$
\text { العلمي والوسط البحثي والتخصص. }
$$

- يلدعم الإثراف على الرسائل العلمية أعضاء هيئة التدريس ضمن عملية الترقية إلى الدرجات الأعلى، كأحد الأنشطة الخاصة بعضو هيئة التدريسيتم احتسابها ضمن محاور التقييم للترقية.

r- أهمية الإشراف العلي للمؤسسة البحثية الجامعية:

للإثراف العلمي المتميز دور مهم في إنتاج مخرجات بحثية متميزة تسهم في رفعة وتقدم الجامعة وحل مشكلات المجتمع ومعالجة قضاياه المختلفة، فعلى قدر جودة الإثراف العلمي تتوقف بشكل كبير جودة وتثيز الرسائل العلمية ونتائجها والعكس صحيح، ففندما يفقد الإثراف العلمي جودته ولا يؤدي أدواره ومسئولياته بكفاءةوففالية، تتأثر جودة المخرجات البحثية وتقل قيمتها التطبيقية والنفية، وتترتب على ذلك أثاراً سلبية على شخصية الثرف والباحث والمؤسسة الجامعية، ويفقد المجتمع ومؤسساته الثقة

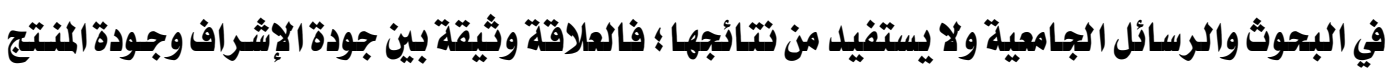

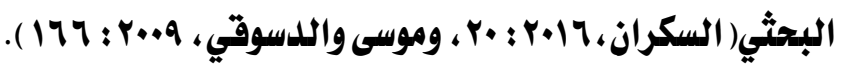

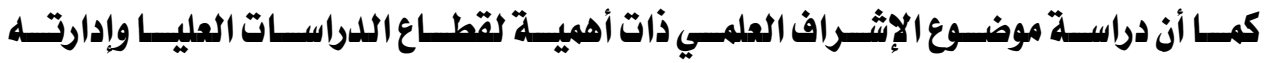
وأعضائه( مشرفين، وطلاب، وموظفين ) لتعرف الموضوعات المتعلقة بالإثراف وضوابط ومعايير اختيسار الشرفين، والعلاقة الإثرافية وتكوينها وتقويهها وكيفية الاستفادة من الجلسـات الإشرافية وتنظيهها،

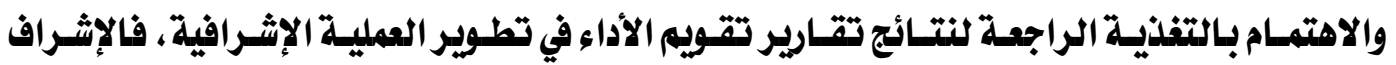

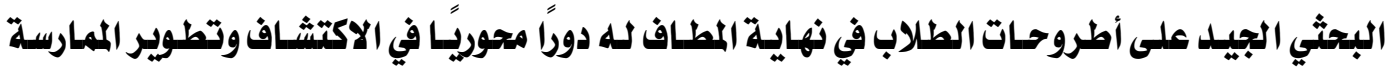

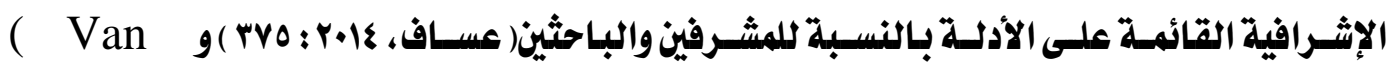
.Rensburg GH, et al, 2016: 1) خاهساً: هواصفات وهقوهات المشرف العلمي الفّعال: تحتاج عملية الإشراف على الرسائل العلمية في ضوء طبيعها وخصائصها وأهميتها- المدكورة

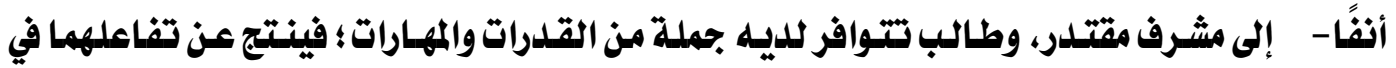
علاقة إشرافية طيبة بحث علمي متميز، فالثرف الفعـال يملد طلابـه بتـدريب بحثي عسالي الجهودة، ويساعدهم في الوصول إلى الموارد البحثية، ويتتتع بـالخبرة والمرونة في اختيـار طرائق التعلم والبحث rVY

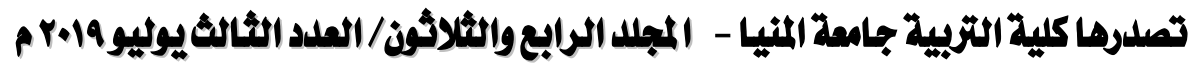
gamel_abdo59@yahoo.com

http://ms.minia.edu.eg/edu/journal.aspx 


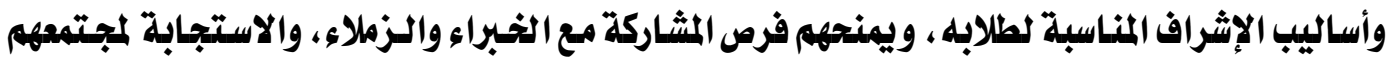
العلمي والاككاديمي الأوسع، فيقلدم لهم النصائح البنّاءة المفيلدة، ويعمل على تهيئة بيئة عمل إيجابية.

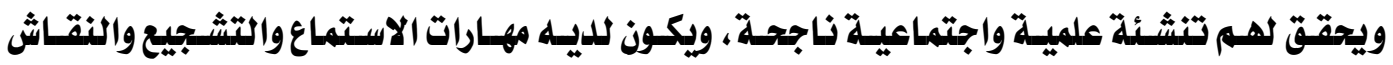
والتواصل والـلعم المستمر، والحمساس والـدفي والتقهم، وإمكانية وسهولة الوصـول وتتـليم المسـاعدة للطالاب في الوقت المناسب، ومعاملة الطالب كزميل صفير، كل ذلك في ظل علاقة إثرافية جيلدة تُشعر الطالب بأن تجربته البحثية كانت مثمرة (41 - Dimitrova, 2016:40).

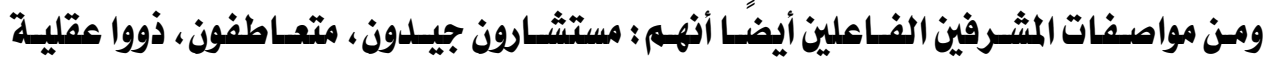
متقتحة ومرنة، يجيلدون ممارسة علاقة القوة والسلطة في الإثـراف بطريقة متزنة ولصـالج الباحث، متقنوز لمهارات التقييم، وقادروذ على إعطاء مؤشرات واضحة ومتكررة لتقيييم الأداء البحثي لطالابهم، والاكثر من ذلك أنهم مشرفون جيـلون يستمتعوز حقًا بـالإشـراف، وملتزمون بمسئولياتهم تجـاه طلابهه ونهوهم المهني مع الالتزام بـالأدلة والقواعد المؤسسية للإشراف والمشاركة في إعدادها وتطويرها، ولديهه حس من الفكاهة التي تساعدهم في العمل مع طلابههم وتذليل الصعاب البحثية، وتحقيق منظور صحي للإثراف العلمي، ولعل هذه السمات الشخصية عوامل مهمة تؤثر على القدرة والبراعة في الإثراف العلمي (Abiddin, et al, 2009:13) كما حدد ليسنج وسكولز 2003:160) Lessing\& Schulze) مواصفات رئيسة للمشرف

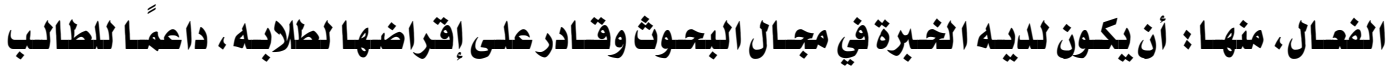

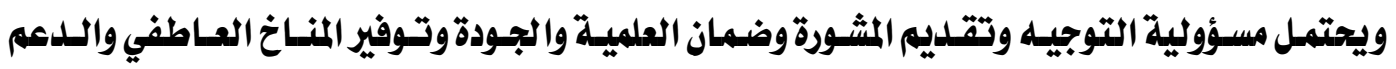
النفسي، وأن يكون مصدرًا للإلهام الفكري، مليراً للموارد والتفييير، معلمَا للكتابـة الاكاد يمية والعلميـة

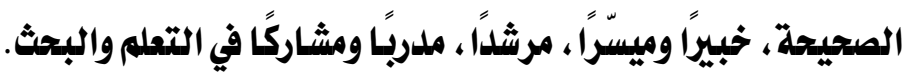
والمرف العلمي الفعال ينبفي أن يكون لليـه المعرفة البحثية والمهارات ذات الصلية بـالتخصص ومهـارات الإدارة كمنـاصـر ضـرورية لممارسـاته الإثـرافية، فـأدوار المشـرف أصبحت أكثر تنوعًا تعقيـلًا

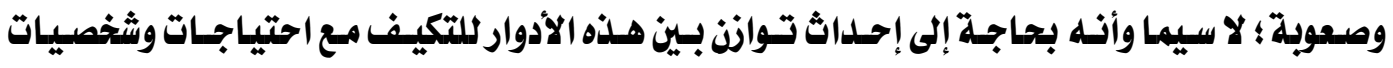
الباحثين المختلفة(Calma, 2007b,:92) ؛ ولـذا يُتوقع من المشرفين أن يكونوا نشيطين وداعمين، rvV

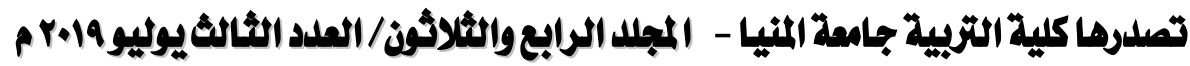
gamel_abdo59@yahoo.com

http://ms.minia.edu.eg/edu/journal.aspx 
دودين، صبورين، آمناء، جليرين بـالثقة، منفتحين ثقافيـاً، مرنين معرفيـا، متسـامحين وغير متحيزين، كمـا يجب أن يكونـوا على درايـة بـالبحوث وا تجاهاتهـا الحديثة في مجسال التخصص، ولـليهم خـبرة في الإثراف ومهتمين اهتمامًا كبيرًا بموضوع بحث الطالب. (5an Rensburg, et al, 2016: (V)، ويمكن إجمال أهم مواصفات ومقومات المشرف العلمي على رسـائل الماجستير والدكتوراه، في مجموعة من

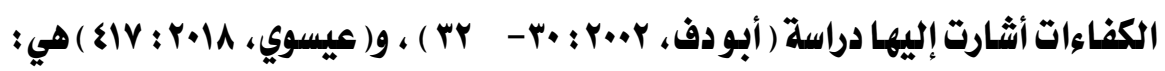
ا

وتعني امتلاك المشرف لمهارات التخطيط والتنظيه والتنسيق والتوجيه والمتابعة، التي تجعله قادرًا على مساعدة وتوجيه الباحث ابتداءًا من احتيار موضوع البحث وتحليـد مشكلته وانتهـاءً بـالنتـائج والتوصيات، ومن مواصفات المشرف في هذا الجانب : القدرة على التوجيه والإرثـاد، والتقويم والمتابعة والنقل الإيجابي البناي، وتقليم العوز والمسـاعلدة لباحث، والقدرة على وضع مخطط زمني لإنجازالمهام البحثية بـالاتفاق مع الباحث وبمـا يناسب قدراته ومهاراته ، وإعطـاء الطالب تفليـة راجعة عقبكل فصل ومر حلة في بحثله، ومتابعة مستوى التقلدم في وطريقة الكتابة العلمية والنمو العلمي للباحث، والمعاونة في تطبيق طرائق البحث وصولًا للمستوى المنشود من الأداء البحثي. r- الكفاوة والتميز الأخلاقي:

ويقصل بها اتصاف المشرف بأخلاقيات العلم والبحث العلمي من إخلاص وتعاون، وأن يكوز قدوة حسنة، متفرغًا لممارسة الإثراف ومسئوليات التوجيه والمتابعة ...إلخ، فالعملية البحثية والإثرافية عملية أخلاقية، إضـافة إلى كونها عملية علميـة منهجية تؤدي إلى مزيـلـ من المعرفة، ولـئن كان البحث العلمي من عمل العقل، إلا أنه لابلد أن يستند إلى قيه أخلاقية حقيقية، وميثاق أخلاقي يلتزم بـه الباحث والششرف، وفي ضوي ذلك يتوجب على المشرف أن يتحلى ببعض المقومات الأخلاقية، ويعمل على تنميتها للى طلابـه ، ومـن أهمهـا : الأمانة العلميـة، والتواضـع العلمي، والمرونـة الفكريـة والبعـل التعصب والتحيـز، والموضوعية وتقدير جهود الآخرين، والنقل الأمين، وعدم التنكر للآخرين، وشكر وتقدير كل من قدم العون والمساعلدة الحقيقية لـه ، والانفتـاح على خهبرات الآخرين والحرص على الاستفادة منها، وتجنب النفاق الاجتماعي، وإخلاص العمل، واستشعار المسئولية، والقدرة على التواصل والتفاعل مع الآخرين. 


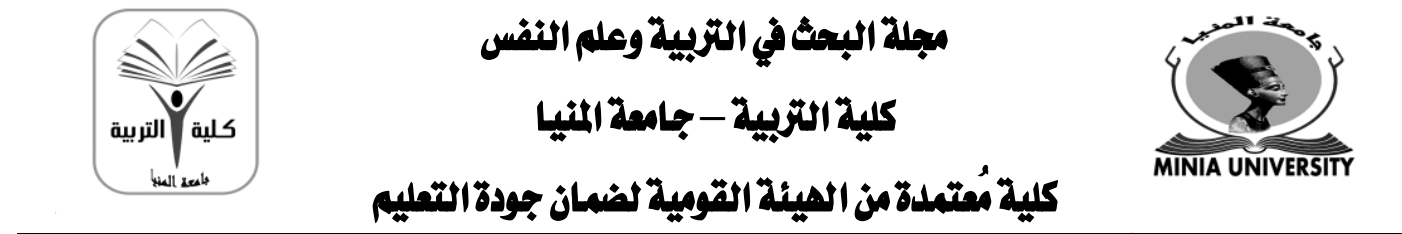

\section{r- الكفاوة الإنسانبة والاجتماعية:}

وتعـي قدرة المشـرف على التواصل والاحترام المتبـادل بينـه وبـين طلابـه بطريقة إنسـانية، ومشاركتهم مناسباتهم وظروفهم الاجتماعية، كما يتجسد ذلك في قدرة المشرف على توفير بيئة إنسانية مريحة للطالب الباحث، قائمة على التفاعل والتعـاون والتحفيز المستمر الدي من ثــأنه دفع الباحث للإنجاز، وتوثيق العلاقة الإثرافية بينهما وتوطيدها بـالعلاقات الإنسانية، ومن ثم ينبفي أنيتصف الأستاذ المشرف بهله المهارات والمقومات، فيعمل على إظهار المودة للطالب، والتز حيب والاهتمسام بـه في أي وقت، وتشجيع الطالب وحفزه على الإنجاز، وتقديره واحترام شخصيته ، والتيسير عليه - بمـا لا يخل بهلف البحث ومنهجيته - ، والعمل على تنمية ثقة الطالب في نفسه وقدراته ومهاراته. ومن خلال هذه المواصفات والمقومات في الجوانب الثلاث التي ينبفي أن يتمتع بهـا المشرفوز على الرسائل العلمية، يستطيع كل مشرف أداء أدواره ومسئولياته الإثرافية بفاعلية ؛ ممـا يسهم في إخراج رسائل علمية ذات جودة عالية، وتكوين عقلية علمية مبلدة لباحث متميز، ولكي يتم اختيار مشرف علمي يتمتع بـالمواصفات والمقومات السابقة لابلد من وجود معايير لجودة هذا الاختيار. سادسا: همعايير جودة اختيار المشرف على الرسائل العلميسة:

هناك مجموعة من المعايير التي يته في ضوئها اختيار المشرف على الرسائل العلمية، حيث ينبفي اختيار المشرف العلمي المناسب في ضوء أسس ومعايير محددة، حتى لايقوم بهله المهمة الإثرافية إلا من كان

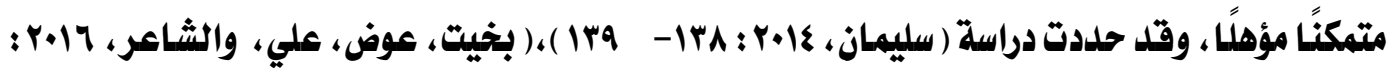
• 11 ) بعض معايير جودة اختيار المشرفين على الرسائل العلمية، ومنها أن يكون المشرف :

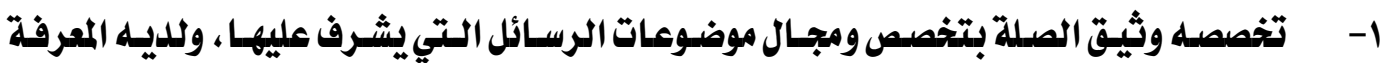
المتخصصة الكافية اللازمة للإثراف.

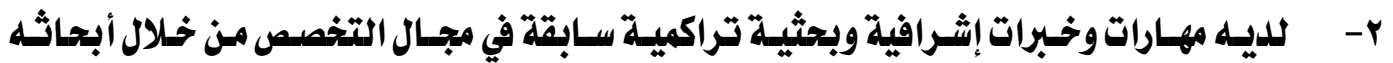
للترقية، وقدرات ومهارات مناسبة لمتابعة أعمال الباحثين ورصد مستوى تقدمهم وتقويم مستوى

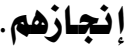
ب- قادراً على تقليه الدعم الكافي والتوجيه والمشورة للطلاب الباحثيز خلال مراحل البحث المختلفة.

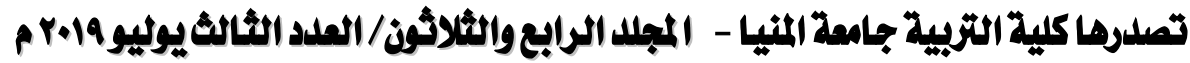
gamel_abdo59@yahoo.com http://ms.minia.edu.eg/edu/journal.aspx 


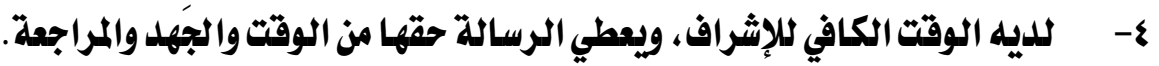

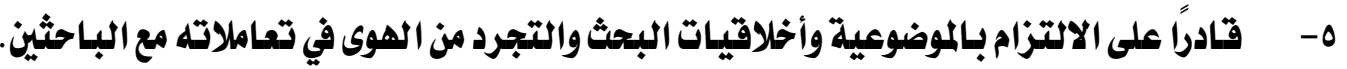

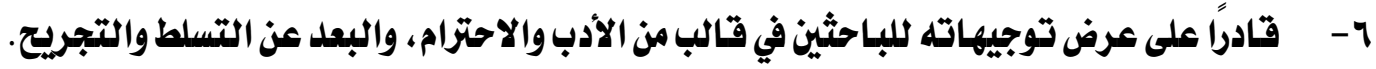

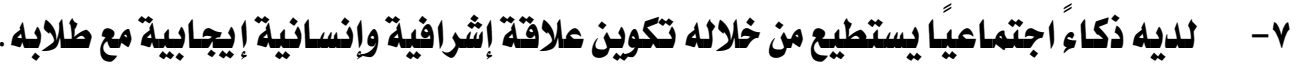

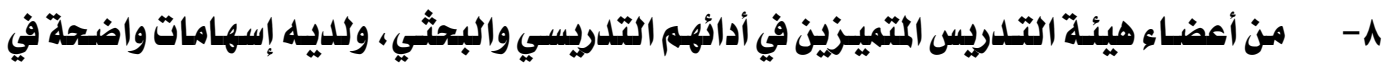
تقدم المعرفة وتطورها بمجال تخصصه من خلال أبحاثه المنشورة. وينبفي التأكيد على أهيـة أن يكون الشرف العلمي الـني يـتم اختيساره للإشراف على رسائل الماجستير والدكتوراه للديه خبرات إشرافية تراكمية يكتسبها من خلال عمله المتواصل في مجال التخصص، وهذه الخبرة لا تأتى بكمية الرسائل التي يشرف عليها، ولكن بنوعية وجرودة هذه الرسائل، وأن تكون للديه خبرة بحثية من خلال أبحاثه المنشورة تقكنه من فهم موضوع الرسائل التي يشرف عليها ، وتعينه على

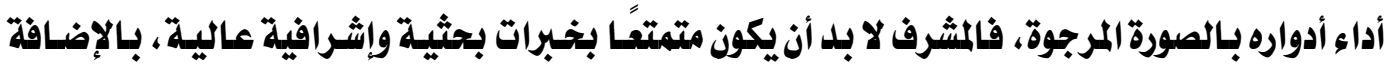
لسعيه ورغبته في تطوير هذه القدرات وا الخبرات من خلال الاطلاع على كل ما هو جديد في مجال الإثراف،

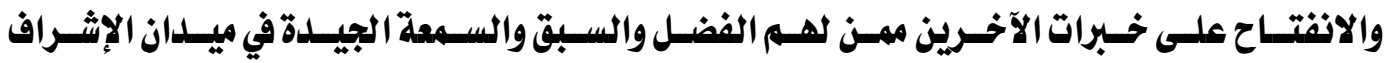

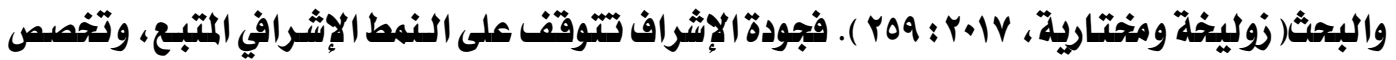
الثرف وعلاقتهل بششروع الطالب، والخصـائص الشخصية، والمكانة الاككاد يميـة والفكريـة والثقافيـة كلثرف (Grant, Hackney \& Edgar, 2014:45).

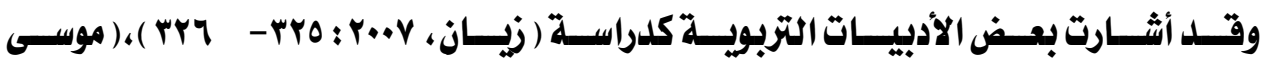

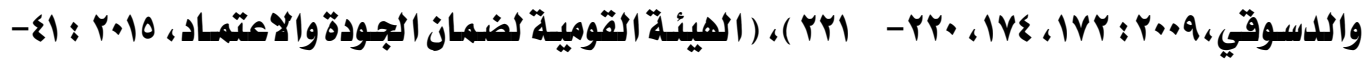

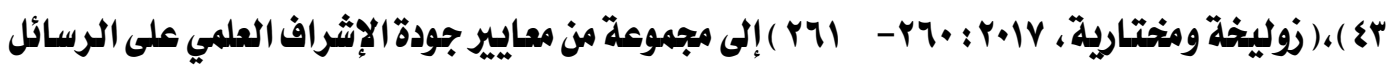
العلمية، ينبفي أن تأخذ بها الجامعات وإدارة الدراسات العليا وبالكليات وأقسـامها العلمية عندل اختيار الشرفين وتشكيل لجان الإثراف العلمي على الباحثين وفي إدارةوتنظيه العملية الإثرافية بصفة عامة، ويمكن تلخيص هذه المعايير في الآتي: ا- التأكيلد على الكفـاءة المهنية للششرفوالمعايير المرتبطة بقدرته على التوجيه والمسـاعلة، 


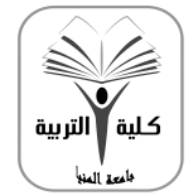

$$
\text { مجالة البحث في التربية ومام الثنسن }
$$

كالية مُتملةةمن الميية القومية لضمان جودة التمليم

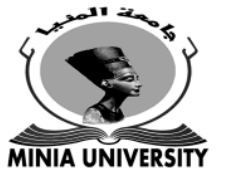

وأهليته للقيام بمسئولياته وأدواره على أكمل وجه في ضوي علاقة إشـرافية يسـودها الـود والاحترام

المتبادل مع بـاحثيه.

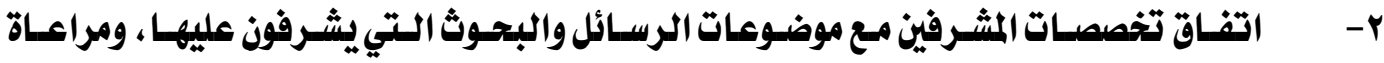

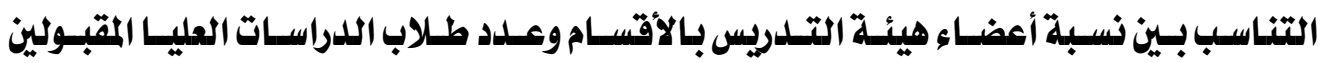
للماجستير والدكتواره ؛ حتى يمكن توفير الإشراف المناسب.

r- تحليد العبء الإثرافي لعضو هيئة التدريس، وتناسبه مع الأعباء الجامعية الأخرى.

ع- التأكيـل على المشـاركة الحقيقيـة بـين الطالب ولجنـة الإثـراف في تحمل المسئولية عـن العمل البحثي وإخراجه في شكل متميز ذي جودة عالية. 0- تأكيد مبادئ ومعايير المسائلة والمحاسبية في ضوي الأدواروالمسئوليات لكل من الطالب والمشرف حال التأخر عن الموعد المحلدد لإنجاز الرسايلة أو الفشل في استكمالها، وحسال التميز والنجاح في إخراج منتج بحثي ذي جودة عالية. 1- التزام الششرفين الموضوعية والحيادية والمساواة والنزاهة والشفافية في التعامل مع الطلاب من خـلال : وجـود قواعـل عمل موحسلة، والتـوازن بـين مصـالح الطلاب وسمعـة القسيم العلميـة، تنحيـة الخلافات الشخصية والتحيز وا لمجلات والمحسوبية والواسطة.

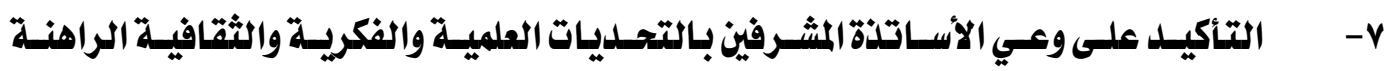
والمستقبلية، وتنمية رغبتهم في تفطية تلك التحليـات واحتياجات المؤسسة بحثيًا من خلال رسسائل طلابهـ. 1- - تأكيد فعالية الإثراف واستمرارية التوجيه والإرثـاد والمتابعة والمسـاعدة والاتتهاء من العمل البجثي وفتًا لخطة زمنية معلنة. و- الالتزام بتوزيع الإشراف وفقًا للتخصص وفي ضوء الأعباء والنصاب الإشرافي لكل عضو. •- توفير إجراءات موثقة وكافية لمتابعة وتقييم أداء الطلاب البـاحثين والمشرفين بلدايلة من التسجيل حتى الانتهاء من البحث، عن طريق والتقارير اللدوريـة ومتابعة حضـور السيمنارات مع الالتزام بتوفير الإمكانات والتسهيلات المادية اللازمة للعملية البحثية. $=r \wedge$

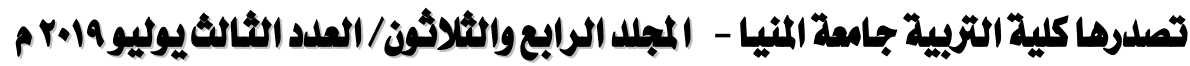
gamel_abdo59@yahoo.com http://ms.minia.edu.eg/edu/journal.aspx 


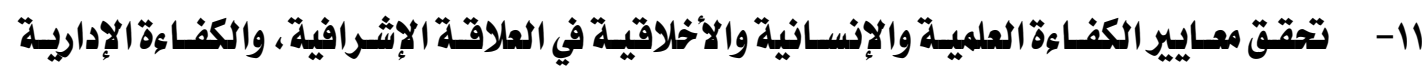
والتنظيميـة في العمليـة الإثـرافية، كمعـيير ثلاثة أساسية لجـودة الإثـراف العلمي على الرسـائل الجامعية.

ومن الجـلير بـالـذكر أنه في بعض الجامعـات لا يكون للطلاب الحق في اختيـار المشرفين عليهيه

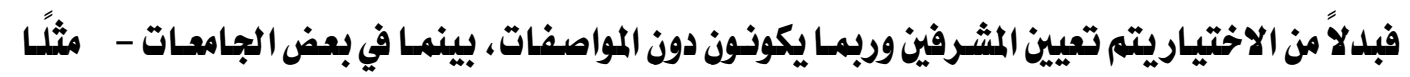

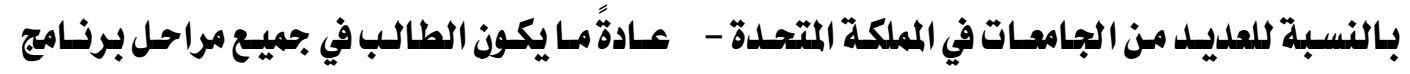
الدكتوراه مسؤوكًا عن اختيار المشرفين الأوائل ولجنة الأطروحة، فيتمتع الطلاب بحرية اختيار الأثخاص

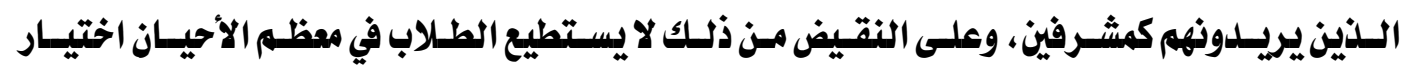
الفاحصين، على الرغم من أنهم في بعض الحالات يهكنهم اقتراح فاحصين يعتقدون أنهم مناسبوز، وينصح

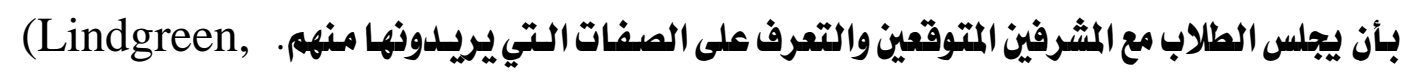
.et al, 2003: 149)

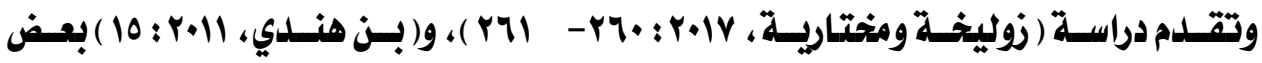
الدراسات مجموعة من المعايير للطلاب الباحثين تساعدهم في اختيار مشرفيهم إذا ما أُخد برغبتهم ورأيهم في عملية الاختيار، ومنها أن يُحسن الطالب اختيار مشرفه ، فيختار مشرفًا : - على علم بأفكاره حول موضوعه بجثه قبل أن يختاره، حتى يكوز هناك توافق وانسجام في العلاقة البحثية والإشرافية.

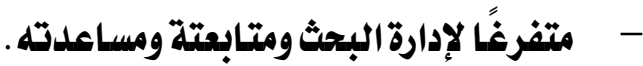
- مهتمًا بموضوع البحث الذي يبحث فيه. - له أبحاث ومشاركات وأعمال لها علاقة ببحثله وموضوعه. - - من القسم والتخصص الذي ينتمي إليه الطالب، ويراعي النصاب الإثرافي الرسمي المحلد. - تكون الأعباء والأحمال الإثرافيه لليه قليلة ( يشرف على عدد قليل من الطلاب ).

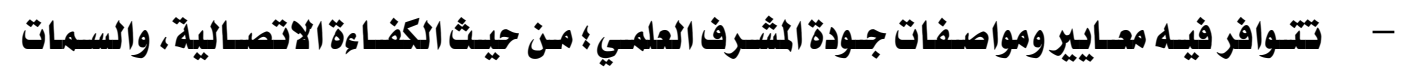
الشخصية، والخبرات الموقفية وا الحياتية كالرغبة في التعلم والبحث وخدمة المجتمع المثـاركات في الجمعيات العلمية والمهنية. rAr

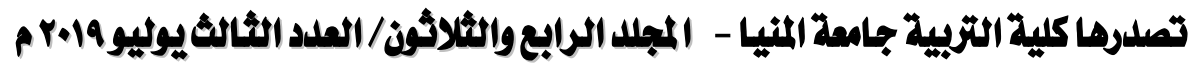
gamel_abdo59@yahoo.com http://ms.minia.edu.eg/edu/journal.aspx 


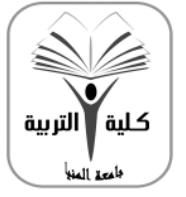

\author{
مجالة البجث في التزبية ومام الثفس \\ كلية التزبية - جامعة المنيا
}

كالية مُتملدة من الميئة القومية لضمان جودةالتمليم

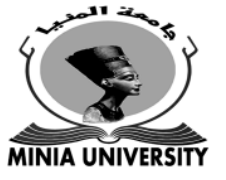

وفي ضوء المقومات والمواصفات التي يتمتع بها المشرف العلمي، ومطابقتها لمعايير جودة اختيساره،

يستطيع المرف والطالب أداء أدوارهما ومسئولياتهما في الإشراف والبحث بفاعلية وكفاءة. سابعا: أدوار وهسئوليات المشرف العابهي والطالب الباحث :

من خلال مطالعة كثير من الأدبيات واللدراسات السابقة في مجال الإشراف على الرسسائل العلمية في مر حلة الدراسـات العليـا، تبين أنها تعــف أدوارومسئوليات المشرف والطالب في اتجـاهين : الأول، يعرض هذه الأدواروالمسئوليات بطريقة عامة واصفًا ما يقوم به المشرف والطالب خلال العملية الإثـرافية والبحثية بصفة عامة. أما الاتجاه الآخر، فيصنف تلك الأدواروالمسئوليات عبر مراحل البحث المختلفة أو يضعها في ثلاثة قوائم هي الأدوار العلمية الفنية التي تخص منهجية البحث وإعداد الرسـالة، الأدوار الإدارية التنظيمية، الأدوار الإنسانية الأخلاقية والاجتماعية عالاقة الإثراف )، وهذه الاتجاهـات شكل من أشكال التصـنيف ليست متضـادة أو متعارضـة بـل متكاملة، ويمكن عـرض أدوارومسئوليـات المشـرف

$$
\begin{aligned}
& \text { والطالب الباحث على النحو الآتي : } \\
& \text { أ- أدواروومسئوليات المشرف العلمي: }
\end{aligned}
$$

يمكن بلـورة أدوارومسئوليات المشرف العلمي في مجـالين أو نثـاطين رئيسييين، أولهمـا : إعـداد بـاحث علمي متمكن، الثاني : إنجاز بحث علمي متميز، وذلك من خلال قدرات ومهـارات وخبرات المشرف البحثية وقدرته على إقامة علاقة إثـرافية وإنسانية وعلمية واجتماعية مع الباحث، وفي ضوء هلذين المجالين والنشاطين، تشير بعض الدراسات إلى أدوارومسئوليات للمشرف العلمي كثيرة ومتعلدة ( مصطفى

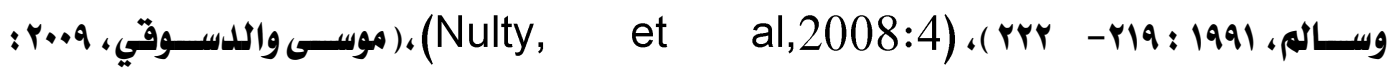

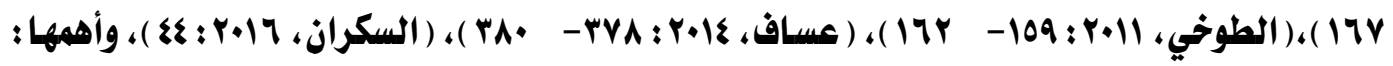
ا- دور المشرف كمخطط: فالمشرف يشترك مع الطالب في إعداد مخطط زمني مفصل للبحث يتضمن قواعد وإرشادات ومواعيد إنهاء المهام، والتفلية الراجعة عقب كل مرحلة حتى الانتهاء من الرسالة ومناقشتها والحصول على اللدرجة العلمية. r- دور المشرف كباحث: فالمشرف بـاحث متخصص، يجب أن تكون لليه معارف واسعة وجيلة في مجال وموضوعات الرسائل العلمية التي يشرف عليها. rar

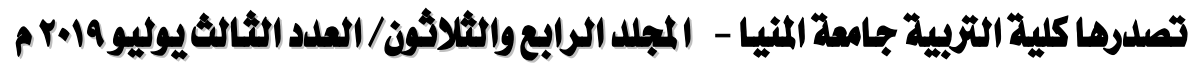
gamel_abdo59@yahoo.com

http://ms.minia.edu.eg/edu/journal.aspx 


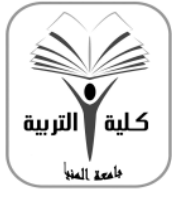

$$
\begin{aligned}
& \text { مجالة البجث في التزبية ومام الثفس } \\
& \text { كاية التزبية - جامعة المثيا }
\end{aligned}
$$

كايلة مُتملمدة من الميئة القومية لضمان جودة التمليم

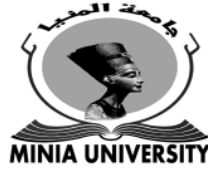

دور المشرف كموجه ومرشد : فالتوجيه والإرشاد جوهر العملية الإثرافية لتوجيه الطلاب وإرشادهم

إلى الطريقة المنظمة لاكتشاف المعرفة واستخدامها بطريقة منهجية سليمة.

§- دور الشرف كصليق ناصح وناقد: وهذا يتطلب من المشرف الموازنة بين كونه مسانداً وناقدًا،

ويتطلب ذلك نصح الباحث ونقل ما يكتبه وتوجيهل بطريقة موضوعية تجعله يتقبل النصح

والنقد.

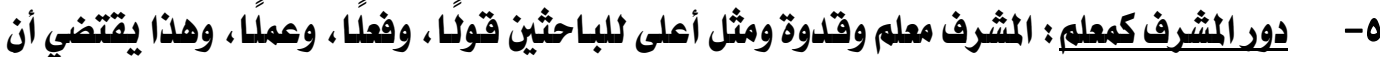

يفرس في نفوس طلابه أخلاقيات البحث العلمي ويلدبههم عليها.

7- دور المشرف كممارس متأمل: يتأمل المشرف عمله ودوره كمشرف علمي، وأفكاره وممارساته

الإثرافية، ويعمل على التقييم المستمر لتلك الأككار والممارسات؛ لتحسينها، وزيـادة معارفه

ومهاراته وفهم التحليات التي تواجهه في مجال الإشراف على رسائل طلابه.

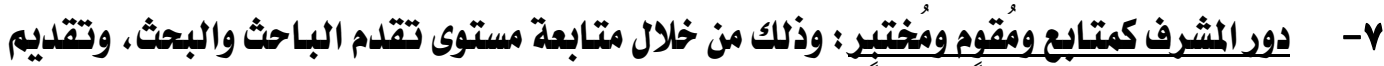

التفلية الراجعة النـاقدة والبناءة حول العمل البحثي والقيام بلدوره كمتحز داخلي، وإبراز نقاط

قوة البحث والباحث فيعمل على تقكينها، ونقاط الضعف لعلاجها حتى يخرج العمل في النهاية عملًا علميا على مستوى عال من الدقة والاتقان، وذلك مع توخي الموضوعية والعدالة في التقويه. 1- دور المشرف كملير وميسر للبحث : يقوم بإدارة العملية البحثية ومراحلها وخطواتها، وييسر ويذلل الصعاب، ويقلد التسهيلات واللدم الحقيقي للباحث حتى الاتتهاء من الرسالة ومناقشتها

والحصول على اللدرجة العلمية.

دور المشرف كمثير ومؤيل: حيث يثير اهتمامات الباحث المعرفية المتعلقة ببحثه، ويرشده ويوجهه

إليها، ويشجه ويناقش ميوله البحثية وأفكاره، فإذا اقتنع بها يؤيلده ويسانده والعكس.

•- دور الشرف كمريبي لروح المسئولية: حيث ينمي المشرف العلمي تلك الروح من خلال إعطاء مساحة

من الحرية والسلطة للباحث لاتخاذ بعض القرارات وتحمل مسئولية تتائجها.

المشرف كزميل أكبر ومثل أعلى : من خلال توطيد عالاقة الزمالة بينه وبيز بـاحثيه في ضوء ميثاق ودستور أخلاقي قائم على الاحترام المتبادل، يكوذ فيه المشرف قدوة ومثًا أعلى للباحثين، ويعمل

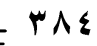

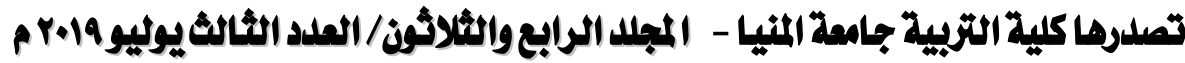
gamel_abdo59@yahoo.com

http://ms.minia.edu.eg/edu/journal.aspx 
على رعاية حقوقهم وتقدير واحتزام شخصياتهم البحثية والإنسانية.

rا- دور المشرف كمدرب: ينطوي على مساعدة وتدريب الطلاب لتطوير أبحاثهم وخبراتهم أثناء قيامهم بالبحث، فلدور الملدرب يشمل : تأسيس شراكة التدريب، ومساعدة الطلاب في تحليلد سؤال البحث والإطار النظري، والمساعدة في تخطيط المشروع وتنقيحه، وتقليم المشورة بشأن الجوانب الحاسمة في البحث، والتوجيه عند الحاجة، والتقيبيم والمتابعة المستمرة. rا- دور المشرف الإنساني والأخلاقي : ويتمثل في اهتمام المشرف بالجوانب الاجتماعية والشخصية في حياة الباحث، ومناقثة أفكاره بـاهتمام وتصويبها، وتخفيزه وتشجيعه، واحترام شخصيته، وئ والثناء على الجوانب الإيجابية فيها. عا- دور الششرف كإداري: ويظهر في الجوانب والإجراءات الإدارية التي يقوم بها المشرف والخاصة بالتسجيل وتقارير الأداء البحثي، وإجراءات المناقشة العلمية الفحص والمنح، ومتابعتة كل ذلك في المجالس الر سمية حتى منح الباحث الدرجة العلمية وتعيينه إن كان من الهيئة المعاونة. وتؤكد إحلى الأدبيات أن المشرف الجيد لا يتوقف دوره واهتمامه بطالب البحث عند الاتتهاء من كتابة الرسالة، فطالب البحث في حاجة مستمرة إلى المساعلة إلى أنيتم الانتهاء من مناقشئة الرسايلة، وأن تكوذ هذه المساعدة التي يقدمها المشرف قائمة على اهتمام حقيقي بكيفية اختيار المنـاقش، وتقديم التوجيهـات الكافيـة حسول كيفيـة الاسـتعداد للمناقشـة العلميـة، وكيفيـة العـرض التقـلـيمي للـنص

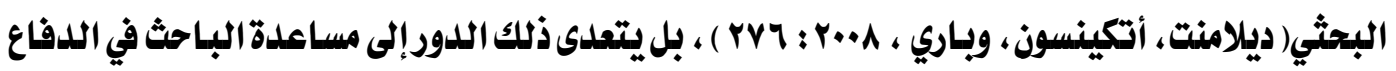

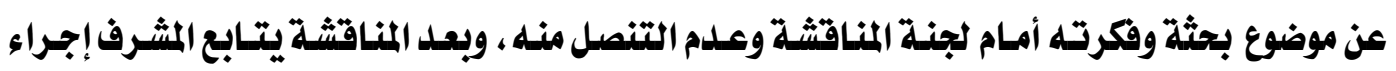
الباحث لما يمكن إجرائه من ملاحظات وتعليلات لجنة المناقثة والحكم على الرسـالة، ويظل دور المشرف مهتدًا مساعلًا ومرشدًا حتي يُمنح الباحث اللدرجة العلمية، بل وفي كثير من الجامعات المتقدمة يمتـد هـدا اللدور إلى مساعدة الباحث في الحصول على وظيفة أو عمل يتنـاسب ومهاراته وطبيعة إعداده وتخصصه ( $)$ فدور المشرف ممتلد عبر مراحل البحث بلديًا من اختيار موضسوع البحث وتسبيله ومعالجته مرورًا بـالمناقشة وأثنائها وما بعدها حتى منح اللدرجة العلمية وقد يمتلد لأبعلد من ذلك كما ذُكر أنفًا، وتتضمن r^o

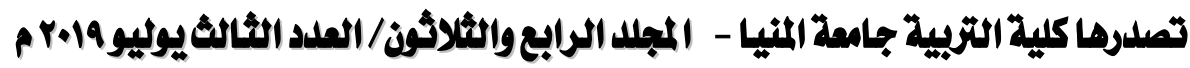
gamel_abdo59@yahoo.com

http://ms.minia.edu.eg/edu/journal.aspx 
أدوار المشرف ومسئولياته أنواع الدعم الاكاد يمي علميًا وفنيًا، والعاطفي والاجتماعي المتمثل في العلاقة الإثرافية الطيبة، بـالإضافة للدعم المادي المتمثل في تسهيل الحصول على الموارد المادية والمالية الخاصة

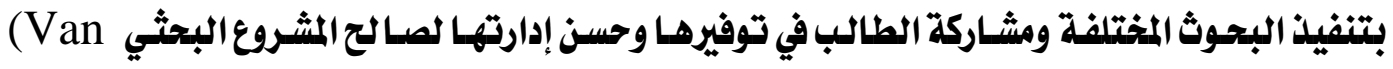
Rensburg, et al, 2016: 7-8) ومن الجـلير بالـدكر أن هنـاك مجموعة من المتفيرات والعوامل المرتبطة بمستوى أداء المشرف لإدواره ومسئولياته الفنيـة والأخلاقية والإنسـانية أهمهـا ؛ المشرف ذاته وخبراته الإشرافية من حيث القدرة على التوجيه واللدعم والمساندة، ومستوى المهارات الإدارية، والقدرة على التكيف مع باحثين مختلفين في المستوى العلمي والسمات الشخصية، وعبء العمل التدربسي والإداري البحثي والإثرافي للمشرف، ومسارات وموضوعات البحوث التي يشرف عليها، ومستوى الاتصال والتواصل مع الباحثين(Calama, 2007b: 92).

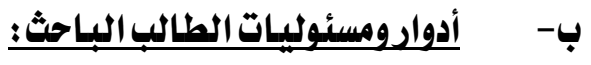

البحث العلمي لا يحتـاج فتط إلى مشرفين متميـزين، ولكن يحتـاج أيضًا إلى فئهة متميـزة من الطلاب الباحثين لهم مؤهلاتهم وصفاتهم التي ثيزهم بسعة العلم والمعرفة وحب الاستطلاع، والسكاء، ودقة الملاحظة والصبر، والأمانة العلمية، والموضوعية، وتوخي اللدقة، وفوق كل ذلكك إيمانهم القوي بـأهمية ما يقومون بـه من أبحاث ورسـائل علمية لإثراء المعرفة وخدمة المجتمع وحل ومشكلاته ... إلخ.

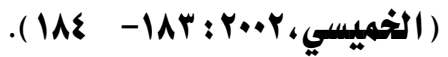

وتتضـمن أدوارومسئوليات الطلاب البـاحثين لإنجـاز رسـائلهم العلمية : تحمل مسؤولية إدارة التعلم والبحوث الخاصة بهه من أجل إنجازها وا لحصول على اللدرجة العلمية، ومعرفة طرق البحث اللازمة واللوائح الخاصة بتقلديم الرسائل والأطروحات العلمية وتوقعات المشرف فيما يتعلق بكل جانب من جوانب الرسالة فهم مسؤولوز عن تحليلد ما هـ المطلوب وتتفيذه، كما يجب أنيبقى الطلاب على اتصـال دائم

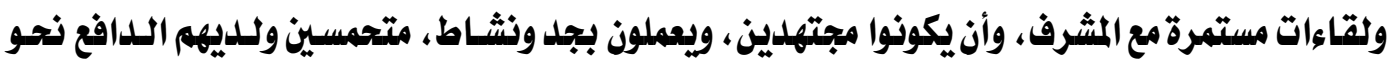
العمل البحثي، وينبفي عليهم إعطاء ردود فمل مستمرة حول أداء المثرف؛ بحيث يمكن للمشرف تقديم تعليمات واضحة، وأن يكوز للدى الطالب الجيل رؤلة أوسع لاحتياجاته التدريبية في مجال بحثه كتطوير المهني بها في ذلك حضور المؤتمرات وكتابة أوراق للنشر ، وحضور الندوات وورش العمل، وتقديم العروض rᄉ

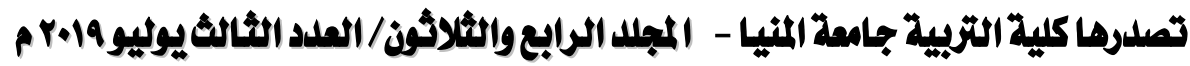
gamel_abdo59@yahoo.com

http://ms.minia.edu.eg/edu/journal.aspx 


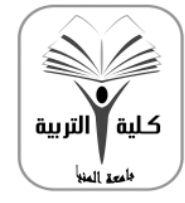

\section{مجالة البجث في التزبية ومام النفس \\ كايلة التزبية - جامعة المثيا}

كالية مُتملةةمن الميية القومية لضمان جودة التمليم

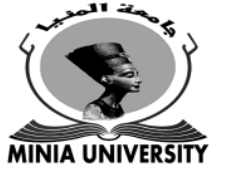

العلمية، والتواصل مع بـاحثين متميزين في مجسال تخصصه ...إلخ، فالطالب هو الشخص الأول والمسؤول

الرئيس عن بحثه وربسالته . (Ali, et al, ,2016: 236).

وهذا يعني أن الطالب الباحث ينبفي أن تتوافر فيه صفات وكفايات علمية وأخلاقية ، بالإضافة

إلى مهارات بحثية تقكنه من المشاركة الفعالة مع مشرفه في إنجاز الرسـالة العلمية على الوجه المطلوب؛ ومز ثم فإن هذا يتطلب الدقة في عملية اختيار الباحثين، ووضع معايير علمية سليمة لانتقائهم فليس كل طالب يصلح لمهمة البحث العلمي ؛ لأن سوء الاختياريلقى بتبعاته على الإثـر اف العلمي والمشرفين الذذين للديهم أعباء أخرى متنوعة داخل الجامعة وخارجها. ثاهنًا: أنهاط وأساليب الإشراف الهـهي: تعدد أنماط وأساليب الإثراف العلمي وفقًا لاعتبارات منها : عدد المشرفين، طبيعة التفاعل بين

$$
\begin{aligned}
& \text { المشرف والباحث، ويمكن توضيح ذلك فيما يلي: } \\
& \text { 1- - من حيث عدد المثرفيزي، } \\
& \text { هناك نوعان من الإثراف العلمي: }
\end{aligned}
$$

أ- الإثراف الفردي: ويقوم على نظام مشرف واحد فقط من هيئة التدريس يعمل مع بـاحث الماجستير أو الدكتوراه، ويكون على عله بصورة مستمرة بما يقوم به الباحث، وهذا يمثل النموذج التقليدي للإثراف العلمي حيث يرشد المشرف الطالب ويعلمه كيفية إعداد بحثه عن طريق إصلار المهام البحثية وإدارتها، وهذا يناسب الطلاب الذين لليهم قدرة واستقلالية، وتتضح عيوبه عند استخدامه مع الطلاب الليز يحتاجوز إلى المزيل من التوجيه والإرشاد والرعاية. (موسى

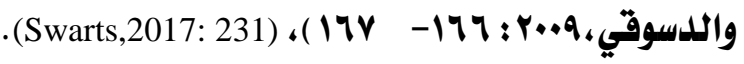

ويتميـز هـذا النـوع بتوثيـق العلاقة بـين المشـرف والطالب، ويجنب الطالب الوقـوع في حسيرة وتضارب الآراء والخلافات التي - التي قد تحدث حال تعدد المشرفيز- أو قوعه فريسة لهذه الخلافات، ويزيل فرصة الاستفادة من خبرة المشرف، وزبـادة شعور المشرف بـالمسئولية تجـاه الطالب، بينما من عيوبـه تقوقع الطالب وحصره في ملدرسة فكريـة واحلدة هي ملدرسة المشرف، وخلاله العلاقة الإثرافية معرضة لسوء الفهم والارتباك وقد يتوقف استمرار الباحث في بحثة نتيجة مثثًا وفاة المشرف أو سفره أو مرضه أو $r \wedge V$

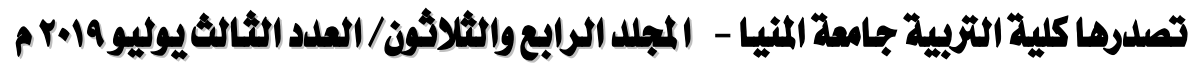
gamel_abdo59@yahoo.com

http://ms.minia.edu.eg/edu/journal.aspx 
كثرة أعبائه وانثفاله وغيابه لظروف متعددة (Cornér, et al, 2017:93) ب- الإشراف الجماعي أو الشترك : عبارة عن إشراف أكثر من مشرف على الباحث قدائ يصل إلى ثلاثة أو

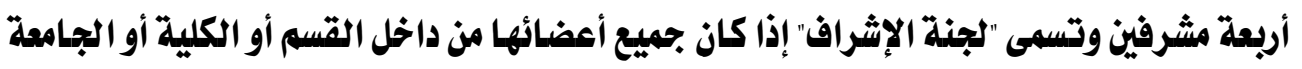
التي ينتمي إليها الباحث، ويسمى إشراف مشترك عند الاستعانة بمشرف أو أكثر من خارج الجامعة

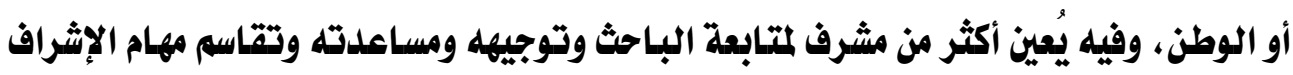

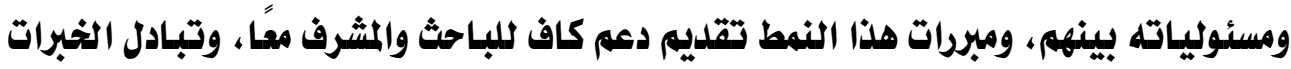
بين الشرفين، والوصول بموضوع البحث للشرفين التتخصين، وإتاحة المساندة للباحث في حالة

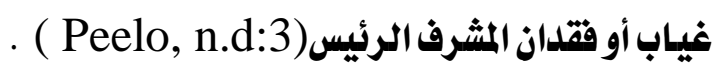

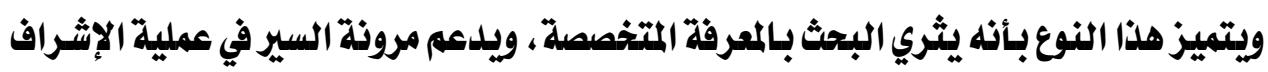

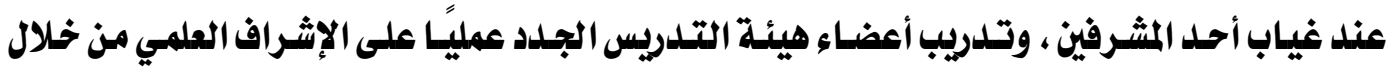

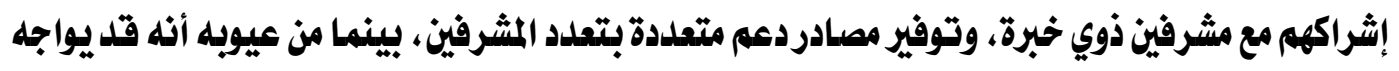

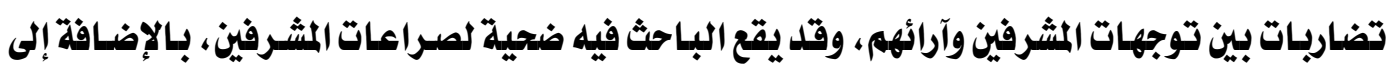

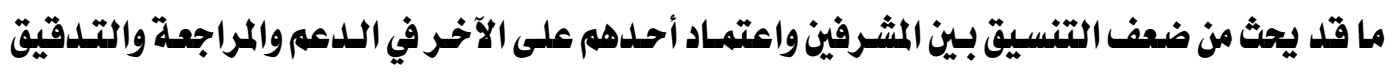

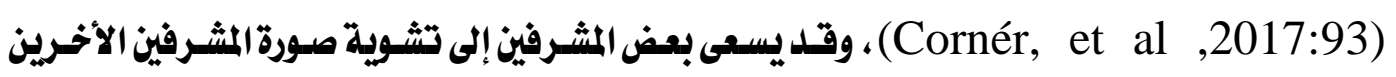

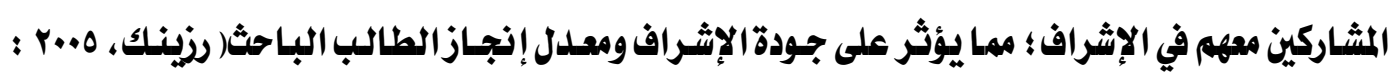

ج- الفرق الإشرافية: نتيجة الرغبة في التفلب على العيوب المرتبطة بالنموذج التقليدي الفردي

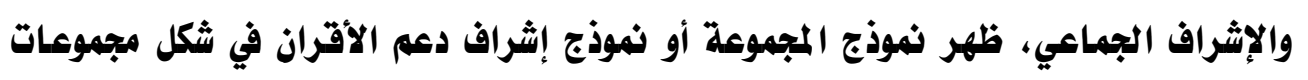

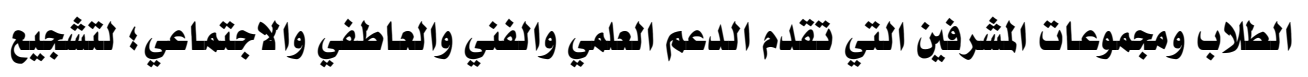

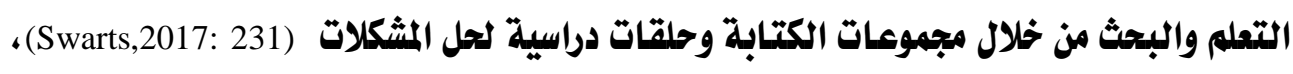

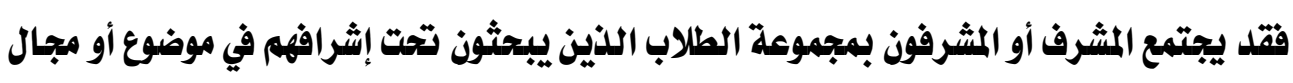

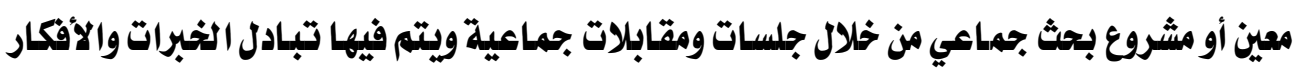

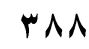

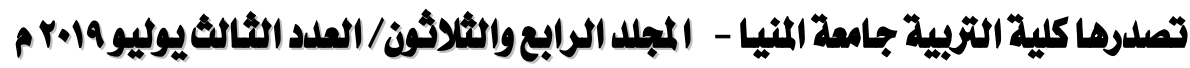
gamel_abdo59@yahoo.com

http://ms.minia.edu.eg/edu/journal.aspx 


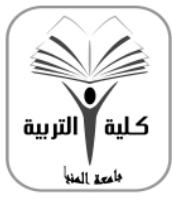

\section{مجالة البحث في التزبية ومطم النفس \\ كايلة التزبية - جامعة المثيا}

كايلة مُتملمدة من الميئة القومية لضمان جودة التمليم

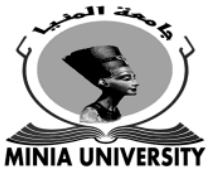

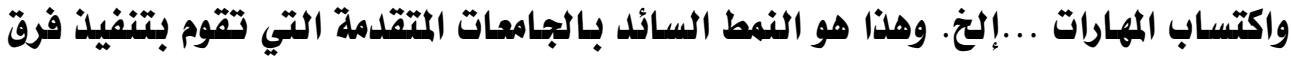
الإثراف معتملة على نقاط القوة والخبرة من المشرفين لإثراء القدرة الإثرافية والخبرات والتنمية المهنية للمشرفين المبتدئين من خلال مشرفين ذوي الخبرة يعملوز كمرشدين للفريق الإشرافي وللطلاب كوسيلة فمالة لإثراء الممارسة الإثرافية (4ulty et al, 2008: ) . r - من ميث درجة التفاعل بين المشرفوالطالب في عملية الإشراف : وفي هذا التصنيف تتوقف درجة التفاعل على مدى مشاركة الطالب والمشرف في العمل البحثي تبعًا لفلسفة وأسلوب المشرف في إشرافه، وفي ضوء هذا الاعتبـار يمكن التمييز بـين ثلاثة أنماط أو أنواع

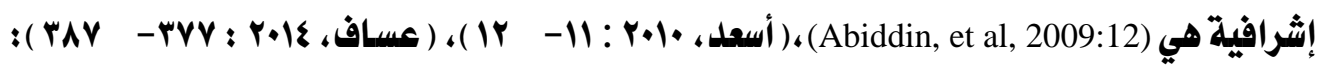
أ- - الإشراف ذو التفاعل القوي: وفيه يظهر التفاعل والثشاركة والعمل الجماعي بين المشرف والباحث، ويكونان متعاونيز متفاعلين بـاستمرار خلال مراحل البحث المختلفة. الإثراف ذو التفاعل المتوسط: وفيه تقل درجة التفاعل والمشاركة، وغالبًا هذا هو النمط السائل في معظم العلاقات الإشرافية بكثير من الجامعات ( إن لم يكن ضعيفًا ). ج- الإثراف ذو التفاعل الضعيف: وتقل فيه درجة التفاعل حتى تكاد تتعلم عملية التواصل

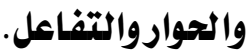

ومن خـالال الأنهـاط السـابقة قـل يتخــذ الأسلوب الإثـرافي الـنهج التـوجيهي لإعطـاء الطالب النصائح والتعليمات في المراحل الأولى للبحث ويقل هـذا المستتوى من التوجيهه مع اكتسـاب الطالب الثقة والقدرة والمهارات البحثية اللازمة، وقدل يستمر التوجيه بـنفس القدلدر من البدايـة وحتى نهايـة البحث، وقد يُوصف الأسلوب الإشرافي بـأنه توجيهي للفاية مع قدركبير من السيطرة والرقابة على الباحث طوال فترة البحث وحتى النهاية. ولعل هذه التصنيفات واتخاذ الأسلوب الإشرافي شككًا منها مرتبطًا بمدى تقكن الباحث وقدراته ومهاراته تلك التي تحسم ملدى تدخل المشرف أو تركه للباحث يعتمد على ذاته، ولعل الإشراف ذو التفاعل المتوسط هو أكثر أنواع هذه التصنيفات انتشارا في الجامعات المصرية وخاصة في مجال العلوم الاجتماعية التربوية والإنسانية- إن لم يكن الإثراف ذو التفاعل الضعيف- ولهدا أسبابه التي ستتضح عندل r^q

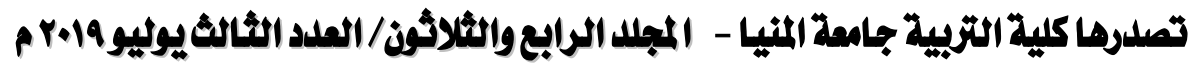
gamel_abdo59@yahoo.com

http://ms.minia.edu.eg/edu/journal.aspx 
دراسة وتحليل واقع الإثراف العلمي بـالجامعات المصرية، كما أن الأنواع والأساليب السـابقة وتصنيفاتها غير متعارضة، وذلك لاختلاف اعتبـارات ومعايير التصنيف، فيمكن أن يكون الإثـراف فردي أو جمـاعي نفسي أو أكاديمي أو تقني ذا تفاعل قوي أو متوسط أو ضعيف إيجابي أو سلبي، والحاسهم في الأمر ملدى تشارك الثشرف الباحث في معالجة موضوع البحث والانتهاء منه في جووعلاقة إشرافية مهنية واجتماعية وأخلاقية متزنة، ومن الجلير بالذكر أن الأدبيات الأجنبية في مجال الإثراف العلمي تزخر بتصنيفات كثيرة لأنماط وأساليب الإشراف العلمي وأنماط المشرفين والباحثين ؛ مما لا يتسع المقام لدكره. تاسعا: العلاقة الإشرافية بين المشرف العلمي والطالب الباحث: إن المُلدخل العلمي المنظم للإثراف على إعلداد رسـائل علمية متميزة يقوم على أسساس أن هنـاك علاقة تبادلية بـين ودوروتوقعـات الطالب الباحث وأستاذه/أسـاتذته المشرفين، وهـذه العلاقة تشبه العقد بينهما على الرغم من كوذها علمية شخصية ؛ حيث يكوز للطالب والمشرف أدوار محددة يجب القيـام

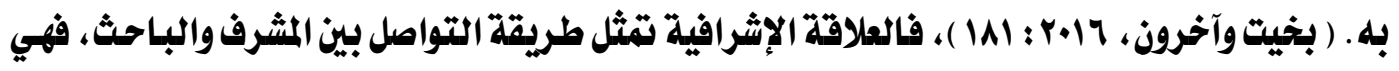
علاقة تشـارك مهنيـة علميـة اجتماعيـة، توفر ردود فمل مستمرة وفمالـة بينهمـا في الأمور الشخصية والاككاد يميـة لإنجـاز الرسـالة العلميـة على أكمل وجـه (Cornér et al, 2017:93)، كمـا أن هـده العلاقة ترسيم تفاوضًا ومناقشـة حـول الحـدود والأدواروالمسئوليات بـين المشرف والباحث فيمـا يتعلق بإجراء البحث فتوصف بـأنها علاقة أكاد يمية أو علمية ....إلخ، وترتبط هـذه الحسلدود بعلاقتات القوة للمشرف والاستقلال مقابل الاعتماد للطالب، ثم تحول الطالب لمضو جلديـل في الاكاد يمية أو الجامعة ، فالإشراف الفمال لا يعتمد فقط على اختصاص المشرف واتجاهـات الإثراف والتزام الطالب، ولكن أيضًا على طبيعة العلاقة الموجودة في مركز عملية الإشراف بينهما بفض النظر عن طبيعة الانضباط أو الأسساس النظري أو التوجيه من حيث علاقات القوة والاستقلال (3-2 : Van Rensburg et al, 2016). وخلال العلاقة الإثرافية بين المشرف والطالب يقلدم الأستاذ المشرف رسالة فكرية ومدرسة علمية تحمل نهجه وفلسفته، ويكوز له تلاميده وبـاحثوه الذين يسيروز على هذا النهج ويتشربوز هـذه الفلسفة

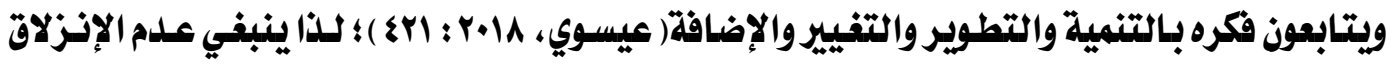
بهذه العلاقة الإثـرافية إلى سلوكيات ابتـزاز أو إذلال أو إهانة الطالب وتسفيه قدراته ، فدلك المسلك

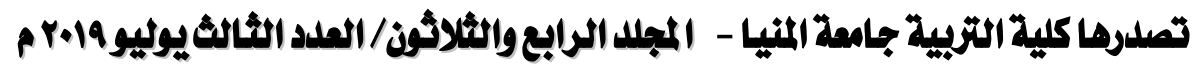
gamel_abdo59@yahoo.com

http://ms.minia.edu.eg/edu/journal.aspx 


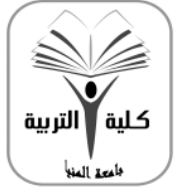

$$
\text { مجلة البعث في التربية وعلم النفس التربية - جامعة المنيا }
$$

كلية مُشتمدة من الهيئة القومية لضمان جودةالتعليم

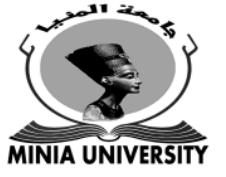

نموذج سيء للطالب، يمس بالضرر شخصيته ؛ وبذلكلك يكون الأستاذ قدل أخل بمسئولته الأخلاقية إزاء

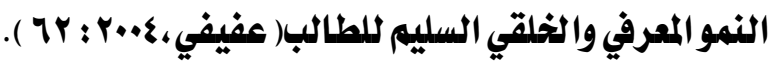

وللذا أقرت الجامعات وقطاع الدراسـات العليـا ضرورة أن تكون العلاقة بين المشرف والطالب

علاقة أكاد يمية ومهنية وأخلاقية ودية إنسانية، فمن غير المقبول أن تكون علاقة مالية أو عاطفية جنسية أو تجارية.... وينبفي تفيير الشرف في حالية تطور العلاقة بـين الطرفين وخروجها عن إطارهـا

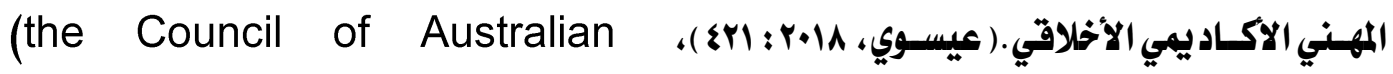
Postgraduate Associations and the Australian Council of Graduate

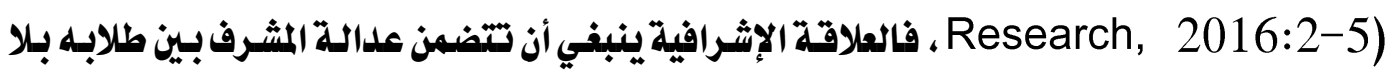
تقييز، وأن يكسبهـ أخلاقيسات البحث العلمي، ويؤكد على أهبية تطبيقها كمبدأ لا يتجزء من شخصية

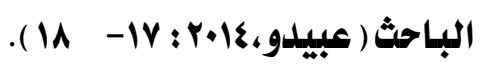

وعند النظر في الجوانب الرئيسة للعلاقة بين المرف وطلاب الدراسـات العليـا يتضح أن الطلاب

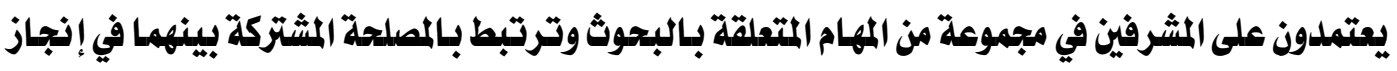

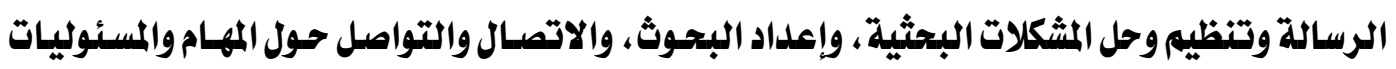

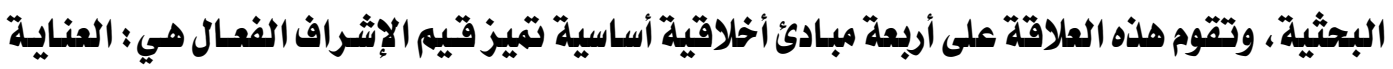

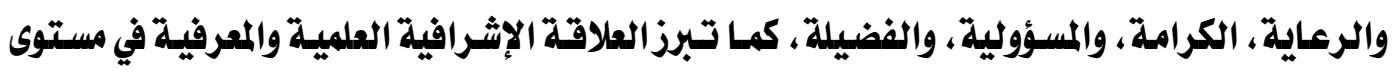
وضوح التوقعات والأدوار المتبادلة بـين المشرف والطالب ؛ بما يؤدي إلى تطوير نمط أو أسلوب الإثراف

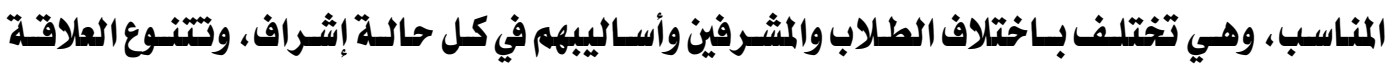
الإثرافية بين الشرف والطاب فقد تكوذ العلاقة مستمرة أو علاقة متشككة، أو علاقة تداولية، وأعلى

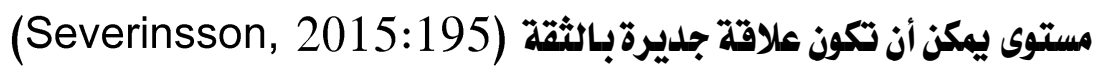

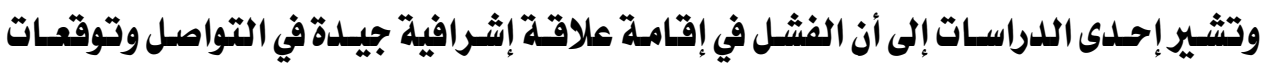
الإشراف على البحوث يمثل أحلد العوامل في بطء وتيرة التقدم البحثي، فالإثراف على أبحاث طلاب

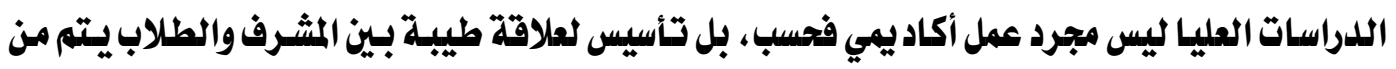

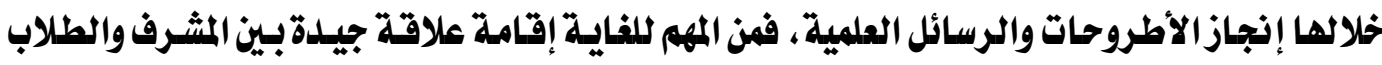
rq1

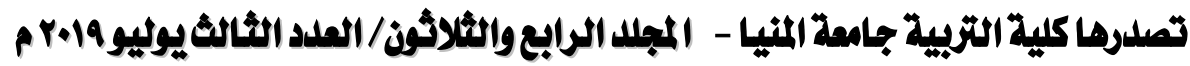
gamel_abdo59@yahoo.com

http://ms.minia.edu.eg/edu/journal.aspx 


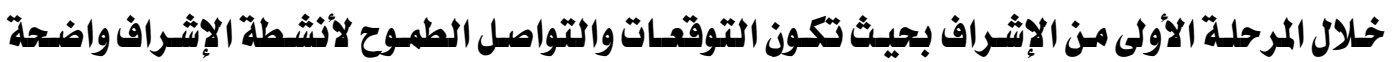
ومحددة بشكل صحيح ومتفق عليها بين الطرفين؛ ولمنع حلدوث مشكلات إشرافية على الملدى البعيلـ ؛ ففالبـاً مـا يكـون الفشل في الإثـراف نتيجـة اخـتلاف التوقعـات، وطـرق التفكير والعمل المتبـاينـة، والصـلـامات

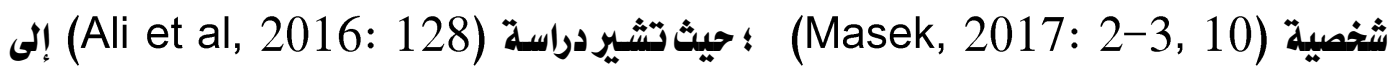
أن الافتراضات والتوقعات الفامضة وغير المتشابهة من جانب المشرف والطالب تثير مشكلات في العلاقة الإشرافية، والعكس فإن الفهم الواضح لدور المشرف والطالب هو أمر حاسم لبنساء علاقة إشرافية صحية ومنتجة والانتهاء بنجاح من المشروع البحثي للأطروحة. وتتوقف جـودة الإثراف والبحوث العلمية بشكل كبير على مدى جـودة العلاقة الإثرافية بـين المشرف والطالب الباحث، فالطلاب الذين يتلقوز الدعم العـاطفي والمسـاندة من المشرفين ومن المجتمع البحثي راضوز بشكل عام عن إشرافهم، وهذا ما تؤكلده دراسة (Cornér et al,2017:102) من أن جودة العلاقة الإشرافية تؤثر على ملدى رضـا الطلاب عن عملية الإثراف والبحث ؛ حيث يتوقع الطلاب أن المشرفين عليهم إرشادهم بطريقة مخصصة ومتخصصة عند الحاجة ومن خلال علاقة إشرافية مفتوحة وموثوقة وجليرةبـالثقة وواضحة فيما تتضمنه من علاقتات علمية واجتماعية وإنسانية بطريقة ودية في ضوء التركيز

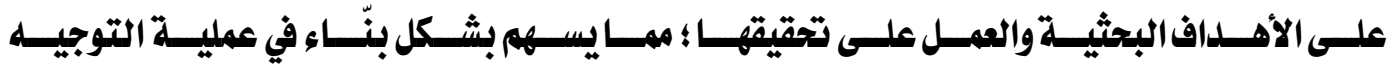
والإشراف. (Lindgreen et al,2003:147, 165-166).

وعلى النقيض تتوتر العلاقة الإثرافية إذا تم النظر إلى عملية الإثراف على أنها علاقة قوة وسيطرة بين شخصين مختلفين وهدف مختلف وتوقعات مختلفة، فإذا كانت الأهداف غير واضحة، ولم تتم مناقشة التوقعات قبل بلداية الإثراف، فمن المؤكلد أن يعمل المشرف والباحث في اتجاهـات مختلفة؛ مهـا يُحدث الصراع بينهما ؛ وعليه فالإثراف الناجح يعتمـل على اتفـاق التوقعـات بـين الطرفين طـوال عملية البحث، فقي ضوء توافق التوقعـات وتبـادل الأدوار الإثـرافية والبحثيـة قدل يكون المشرف أفضل مشـرف للطالب ولكن الأسوأ لطالب آخر والعكس.(Phang et al, 2014:252) وعلى الـرغم من حتميلة وجـود علاقتات القوة بمـا تعينه من سيطرة المشرف وانصياع الباحث وصعوبة تجنب تثلك العلاقة لكونها من صميه عملية الإثراف، إلا أنه بـالإمكان تقليصها إلى أدنى الحلدود 


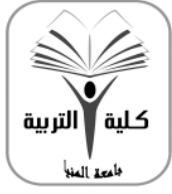

\section{مجلة البعث في التزبية وعلم النفس \\ كلية التربية - جامعة المنيا}

كلية مُعتمدة من الهيئة القومية لضمان جودة التعليم

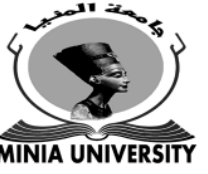

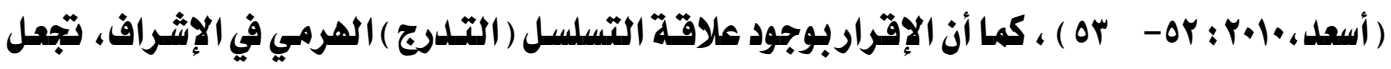
الطلاب والشرفين قادرين على العمل معًا، فيحتاج الطلاب السلطة الشرعية والحق في المطالبة بصوتهمه وآرائهم، وأن يكونوا وكلاء نشطاء عن أبحاثه خالال العملية الإثرافية ومراحل البحث المختلفة، وعليهيه

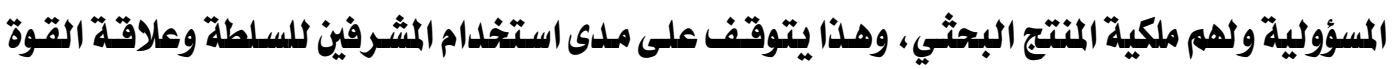
لتسهيل عملية التعلم خلال التفاعلات الاشرافية والتمسك بمبلدأ البنـاء الاجتماعي، فالسلطة كعلاقة يمكن أن تكون قوة إيجابية ومثمرة في توفير فرص التعلم خلال محادثات إثرافية وجها لوجها أو العكس (Tian. and Singhasiri, 2016: 655-656).

والعلاقتة الإثـرافية الوظيفيـة والمهنيـة النـاجحة الـتي تضمن ردود الفصل البنـاءة، والتلـعم

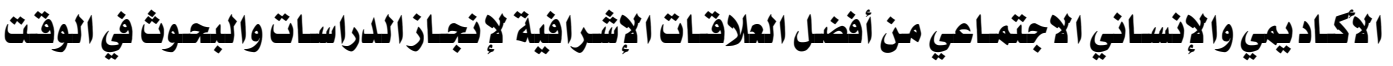
المناسب، وتحقيق الرضا عز برنامج الدراسـات العليـا، وتحقيق الاحترام المتبـادل بين المشرف والطالب، والتواصل الواضح بينهما، والتكيف المرن مع احتياجات الطالب، وتحليـل استراتيجيات واضحة للتقدم نحو الحصول على الدرجة العلمية، فالطلاب يعدون التفاعل الإثرافي خلال هذه العلاقة مهمًا ويستفيدون من فرص عقد اجتماعات متكررة وأجواء مريحة خلال هذه اللقاءات في موقف متعاطف من المشرف ؛ مما يجعلهم يحرصون على التقدم الجيد والرضا عن دراساتهم وأبحاثهم، ويحقق ذلك المساواة بين البـاحثين في المجتمع البحثي (Cornér et al 2017:90,93). وعليه ؛ فإقامة علاقة إثرافية ناجحة تتطلب من الشرفين والطلاب مناقثة التوقعات وأهداف المشروع البحثي، والإطار المفاهييي بوضوح قبل بداية الإثراف، واقتراح الاجتماعسات الدورية لمساعلة الطلاب على الانغراط في البحث؛ لأن مشكلات التواصل يمكن أن تسبب علاقة غير مستقرة، كما أنه لا بــ من تدريب الطالب على الاستقلالية وا لحكم الذاتي، وتجنب - قدر الإمكان- علاقة القوة والسيطرة من قبل الشرف، كما يبنفي تعيين حدود واضحة للعلاقة الإثرافية وتوضيح كل التوقعـات في البداية، والاتفاق على "عقد التعله" بين الشرف والطالب حول الثشروع البحثي الذي يتعين القيام به معًا، ويجب أن يكون للدى المرف والطالب نطاق واضح وأهداف محددة، ولابد من إظهار التزام واضح من الجـانبين بتلك الأهداف، كما يجب أن يكون المشرف داعمًا للطالب في المقام الأول، مع إعطائه أكبر قدر ممكن من الحكم rqu

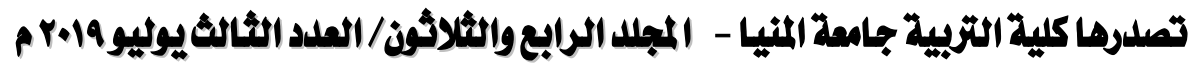
gamel_abdo59@yahoo.com

http://ms.minia.edu.eg/edu/journal.aspx 


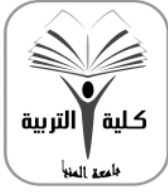

\author{
مجالة البجث في التزبية ومام النفس \\ كايلة التزبية - جامعة المينيا \\ كايلة مُتملمدة من الميئة القومية لضمان جودة التمليم
}

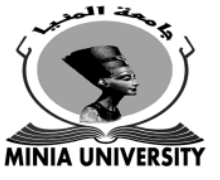

الذاتي والاستقلالية دوذ السماح له أن يكوز صاحب الرأي الأول والأخير ؛ فهذا قد يسهم في إيجاد علاقة إشرافية إيجابية وإنجاز جيد للأطروحة مشروع البحث.) (3) -2 : (Abdallah et al, 2010) ومن العرض السابق لطبيعة العلاقة الإثرافية بـين المشرف العلمي والطالب الباحث وأنواعها، يتضح أهمية تأسيس وإقامة هذه العلاقة على أسس وقواعلد وضوابط علمية وأخلاقية وإنسـانية سليمة وواضحة ومحددة؛ حتى تأتي هذه العلاقة بثمارهـا في إنتـاج رسـالة علميلة ذات جـودة عالية، ف فالعلاقة الإشرافية تقثل قلب ولب عملية الإثراف ومفتاح ذجاحها. عاشرا: التنـمية المهنية لأعضاءهيئة التدريس في همال الإشراف العلمي: تُعد التنمية المهنية لأعضاء هيئة التدريس أحلد المرتكزات الأساسية لإصلاح التعليه الجـامي من خلال الارتقاء بمستوى قدرات ومهارات أعضائه، وإكسابهم طرائق جليـلدة لتحسين ممارسـاتهم وأداء أدوارهم ( التدريسية والبحثية والإثرافية ) بكفائة، وتخريج طلابٍ وبـاحثين متميزين يستطيعون خوض

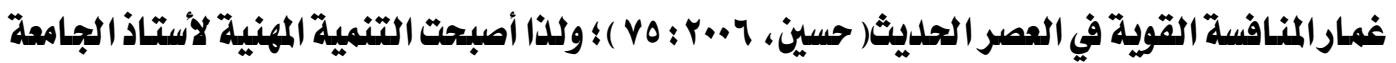

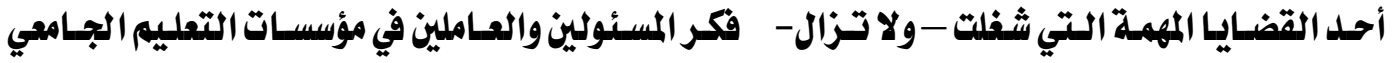
والبحث العلمي؛ حيث تحرص الجامعات في مختلف دول العالم على التنمية المهنية لأعضاء هيئة التدريس في مختلف أدوارهم ووظائفهم الجامعية- لا سيما الدور البحثي والإشرافي- وتقدم لهم العليـل من

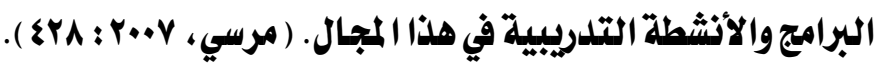
وتُعرف التنمية المهنية في مجال الإثراف العلمي بأنها تلك الجهود المنظمة والمقصودة التي تقوم بها الجامعة ؛ بهدف تطوير المعارف والأفكاروا لخبرات واكتساب المهارات، وتتميـة الاتجاهـات الإيجابية للدى أعضاء هيئة التدريس؛ مما يجملهم أكثر فمالية وكفاءة في الوفاء بـالأدواروالمسئوليات والإشرافية

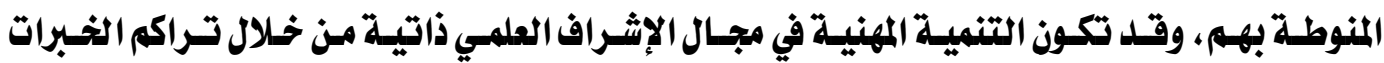
الإشرافية، وتأمل الممارسات الإثرافية وسي المشرف لتحسينها وتطويرها، والبحث عن أساليب إشرافية حليثة، وعلى أية حال تركز التنمية المهنية للمشرفين على ثقكينهم من التكيف مع طبيعة البـاحثين، وتوسيع فهمهم لطبيعة البحث العلمي والممارسـات الإثـرافية في ظل المتفيرات الثقافية والاجتماعيـة

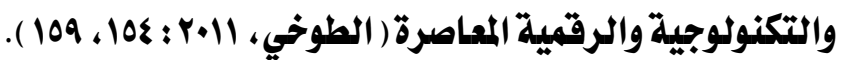
- rqs

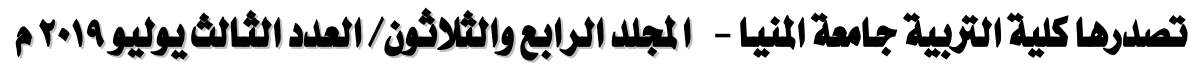
gamel_abdo59@yahoo.com

http://ms.minia.edu.eg/edu/journal.aspx 
وفي ظل العصـر الرقي وتحولاته التكنولوجيـة، ومـا نتج عنهـا من ثورة علمية ومعلوماتيـة ومعرفية في مجال البحث العلمي، أصبحت عملية الإثراف العلمي على رسائل الطلاب البـاحثين بـالدراسـات العليا أكثر صعوبة وتعقيلًا ؛ ومن ثم فإن المشرف يحتاج إلى قدر من التلدريب على المهام الإثرافية مثل : كيفية تحسين عملية توجيه وإرشاد طلابه وتنمية قدراتهم ومهـاراتهم البحثية، وتحسين مستواهم في اللفة التي يلدرسوز ويبحثون بها مع الاهتمام بتنمية مهارات الكتابة العلمية؛ للذا فعلى المشرف أنيضع في حسبانه مدى قدرته على القيـام بتلك المهام بفاعلية من عدمهه قبل قبـول هـذه المسئولية الإثـرافية

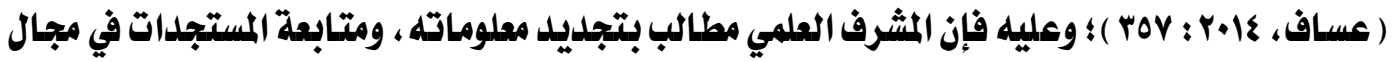
تخصصـه العلمي وفي مجـال الإثـراف من خـلال حضـور المؤتثرات والنـلدوات العلميـة والمناقشـات وكتابـة الأبحـاث ؛ حيث ينبفي أن يتـوافر لـدى المشرف الثقافة الواسعة في مجـال التخصص، والمرونـة الفكريـة، والقدرة على التعامل مع الطلاب البـاحثين بـأنفـاطهم المختلفة، وللديه قـدر عـال من الكفـائة والفمالية

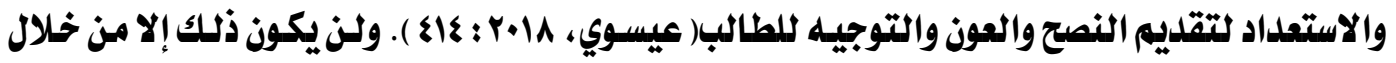
التثمية المهنية المستمرة في مجال الإثراف العلمي وأساليبها ومصادرها المختلفة.

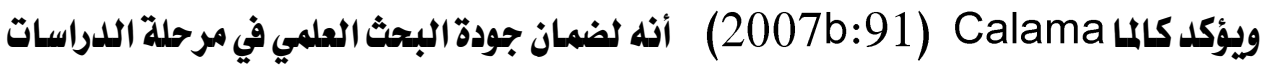
العليا أصبح المشرف مطالب على نحو متزايلد بـالاهتمام بـالتنمية المهنية من أجل أداء أدواره ومسئولياته بشكل فمال لقيادة الطلاب ذحو الانتهاء من أطروحساتهم بنجـاح ؛ وهدا يجعل المشرفين في حاجة دائمة لحضور دورات تدربيية ومؤتهرات وندوات علمية تصقل مهـاراتهم للتعامل مع متطلبـات ممارسة أدوارهم كمشرفيز على البحوث، فالتدريب الخاص بـالإشراف هو مجال اهتمام متطور ليس فقط للمشرفيز والطلاب البـاحثين ولكن أيضـا لفيرهـم مـن أصـاب المصلحة والمستفيلين الـذين يرغبـون في فحص الأطروحسات ومناقشتها، كما يسعى المشرفوز أنفسهم إلى الاستفادة من نصائح زملائهم الخبراء حول كيفية تحسين جودة الإثــراف البحثـي كأحسل أسـاليب التنميـة المهنيــة في مجــال الإثــراف علـى الرســائل والأطروحسات العلمية (Lindgreen et al ,2003:149). فالمشرف العلمي يحتاج إلى التنمية المهنية المستمرة للوقوف على أحلدث المستجدات، والأسـاليب الإشرافية المتبعة في الجامعات المتقدمة، فقي جامعات جنوب أفريقيا - على سبيل المثال - يتم اعتماد rqo

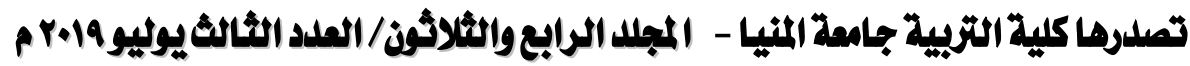
gamel_abdo59@yahoo.com

http://ms.minia.edu.eg/edu/journal.aspx 
المشرف رسمياً كمشرف بعل حضور دورات التطوير المهني من خلال برنامج "EP-Nuffic" و" و" "DHET" الممول لتعزيـز الإثـراف على اللدراسـات العليـا، وهو برنـامج تـدريبي رسمي يسعى إلى تعريــ المشـرف بمسؤولياته الإشرافية كاملة، والهدف الرئيسي منه تحسين جودة الإشراف من خلال عملية التأمل الذاتي

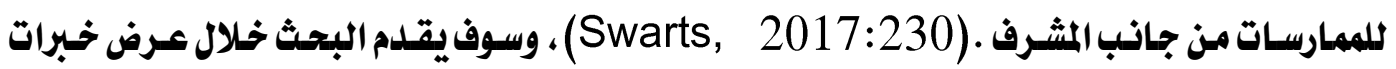
الجامعات الأجنبية المختـارة كيف تتم التنمية المهنية لأعضـاء هيئة التـدريس المشرفين على الرسسائل العلمية، وبيان أهميتها وأنشطتها وأهم أساليبها ووسائلها.

وبعد تعرف طبيعة الإثراف على الرسيائل العلمية وأسسه النظريـة والفكريـة، ومعـيير جـودة اختيار المشرفين وتشكيل اللجان الإثرافية، وأدوارومسئوليات المشرفين والطلاب خلال عملية الإشراف من أجل إنجاز الرسالة العلمية، وأنماط وأساليب الإثراف العلمي، وتعرف طبيعة وحدود العلاقة الإثرافية بين المشرف والباحث، والتنمية المهنية لأعضاء هيئة التدريس في مجال الإشراف العلمي، يحاول البحث في المحور التالي تقديم تشخيص وتحليل لواقع الإثراف على الرسسائل العلمية ووضعه الراهن بـالجامعات المصـرية مـن منظـور التشـريعات والسياسـات البحثيـة والقـوانين واللـوائح الرسميـة المنظمـة، ونتـائج الدراسات والبحوث السابقة في هذا المجال. المهور الثالث: الوضع الراهن للإشراف العلمي بالجاهعات المرية "دراسة تشفصية تهليلية": يتنــاول هــدا المحسور تشـخيص وتحليـل الوضـع الـراهن لواقـع الإثـراف على الرسـائل العلميـة بـالجامعات المصرية من خلال تحليل وثائقي نقدي للتشريعات والسياسات البحثية ولقواثين واللوائح الرسمية الحاكمة والمنظة لعملية الإثراف عل الرسائل العلمية بـالجامعات المصرية ( المواد المنظمة بقانوز

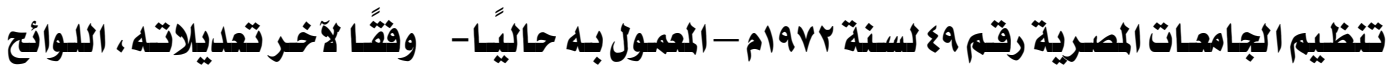
الداخلية للدراسات العليا ببعض الجامعات المصرية وبعض القرارات الجامعية ) فيما يخص تنظيبم الإثراف

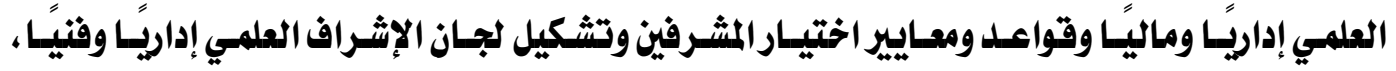
معضدذًا ذلك بنتائج الدراسات والبحوث السابقة في هذا الشأن، ثم رصد وتحليل أدوارومسئوليات المشرف والطالب خلال العملية الإثرافية في مراحل البحث المختلفة، وواقع العلاقة الإثرافية بينهها، وأنشطة وبـرامج التنميـة المهنيـة لأعضـاء هيئهة التـلـريس في مجـال الإثـراف العلمي، وذلـك مـ خـلال مراجمـة 
اللدراسات والبحوث السابقة والأدبيات التربوية المعاصرة في هلذا المجال، وذلك على النحو الآتي:

أوتًا : واقع إدارةوتنظيه الإشراف العلمي بـالجامعات المصرية :

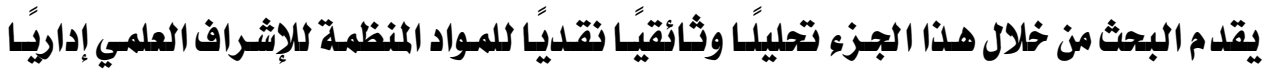

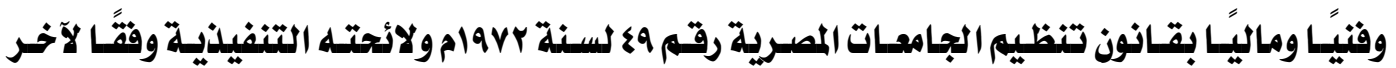
التعـليلات، وأيضـا مطالعـة وفحص اللـوائح الداخليـة للدراسـات العليـا بـبعض الجامعـات المصـرية، مـع

الاستشهاد بنتائج بعض اللدراسات والبحوث السابقة في هذا الشأن.

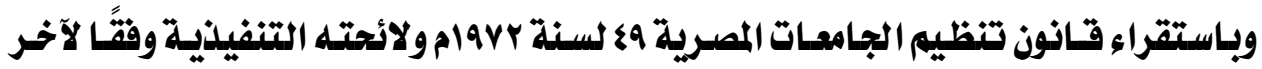
التعليلات، يتضح أن اللائحة التنفيذية لهذا القانوز تتضمن خمس مواد منظمة لعملية الإثراف العلمي

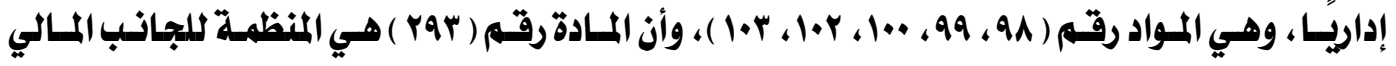
ومكافآت الإثراف العلمي على رسائل الماجستير والدكتوراه، وبنظرة تحليلية فاحصة ناقدة لنصوص هده المواد، يمكن رصل بعض الملاحظات عليها، على النحو الآتي جمهورية مصر العربية، وزارة التعليم العالي، $:(I r \cdot, r \varepsilon: Y \cdot+\eta$

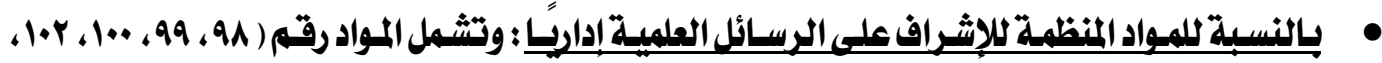
ب. ب. )، ويمكن رصلد بعض الملاحظات عليها، على النحو الآتي:

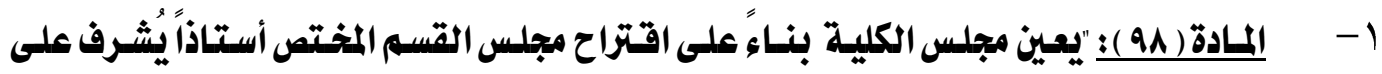
تحضير الرسالة، وللمجلس أن يعهل بـالإثراف على الرسـالة لأحسد الأسـاتلذة المسـاعليز، ويجـوز أن يتعدد المشرفوز من بين أعضاء هيئة التدريس أو من غيرهم، وفي هده الحالة يجهوز للمدربسين الاشتراك في الإثراف، وفي حالة قيام الطالب ببحث خارج الجامعة يجوز موافقة مجلس الكلية أن يشترك في الإثراف أحد المتخصصين في الجهة التي يجري بها البحث."، ويلاحظ أن هـده المـادة لم تنص على مراعاة رغبة الباحث في اختيار مشرفه ، وإنما الأمر يته بـالتعيين من خالال مجلس الكلية بناءً على اقتراح من مجلس القسم المختص، ونصت على جهوازتتعلد المشرفين على الرسـالة لكن دوذ تحليد حلد أقصى لهذا العدد، ناهيك سلبيات الإثراف الجمـاعي والمتعلد على الباحثوقد أشار الباحث إلى ذلك في الإطار النظري- ، كما أجازت المادة اشتراك أساتلذةمن خارج الجامعة rqv

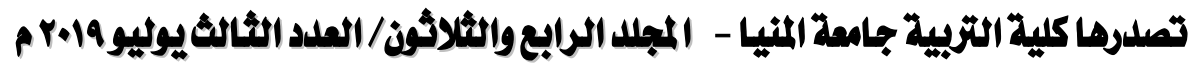
gamel_abdo59@yahoo.com

http://ms.minia.edu.eg/edu/journal.aspx 
أو مشرفين من غير الأساتذة الجامعين كالمختصين ورجسال الميلـدان دوز تحليـل معسيير حاكمة لهـده

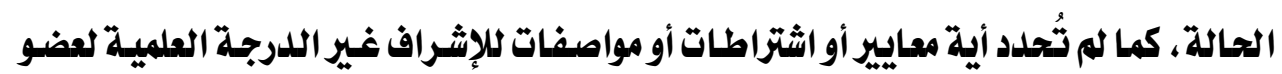
هيئة التلدريس.

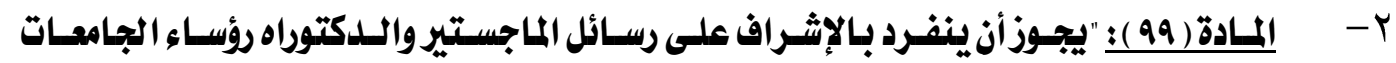
وذوابهه إذا كان التسجيل في الجامعة التي يعملون بها ، فإذا كان التسجيل في جامعة أخرى جـاز لهم ولأمين المجلس الأعلى للجامعـات الاشتراك في الإثـراف ويستمر إشرافهم أو مشـاركتهم في الإشراف على الرسائل التي سُجِلت تحت إشرافهم قبـل شفل مناصبهه." ، نصت المادة على جـواز انفراد رؤسـاء الجـامعـات ونوابهم بـالإثـراف العلمي إذا كانت التسجيل بـنفس الجامعـة، وجـواز الثـتراكهم وأمين المجلس الأعلى للجامعـات في الإثراف على الرسـائل المسـجلة في جـامعـات غـير جامعاتهم، واستمرار إشرافهم على تلك الرسائل قبل شفل مناصبهم، وهنـا يُطرح سيؤال : كيـف يتسنى لهؤلاء المشرفيز متابعة البـاحثين وتوجيههم في ظل أعبـائهم الإداريـة، وصعوبة وصول الباحثين إليهم والحصول على دعمهم وتوجيههم؟، وخاصة في حالات الانفراد بـالإشراف.

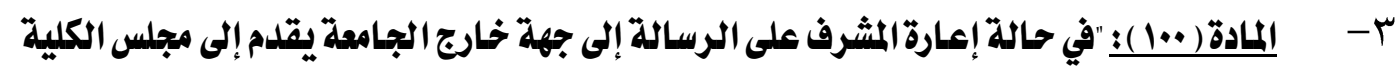
تقريراً عن الملدى اللذي وصل إليه الطالب في إعداد الرسالة، وفي ضوء ذلك يعين المجلس من يحل

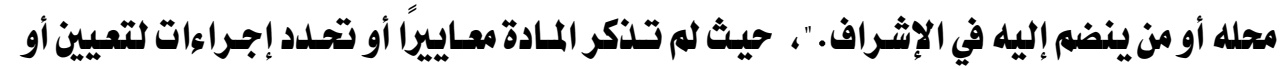
اختيار مشرف بلديل في حالة إعارة أو سفر المشرف الرئيس أو أحلد المشرفين المسـاعلين، وأين دور

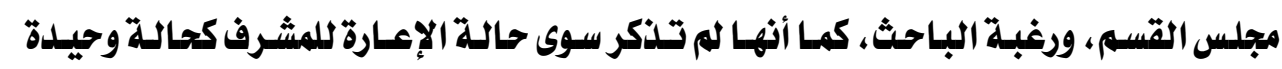
لاستبلداله وتعيين غـيره، ولم تنظـر إلى حسالات عـدم التوافق بـين المشرف والباحث واستحالة استمرار العلاقة الإثـرافية في ظل عـدم التوافق، أو حسالات مـرض أحسد المشـرفين أو سـفره أو انتلابه أو وفاته ، كما لم تضمن للباحث استمرارية مـا وصل إليه من تقدم مع لجنـة الإثـراف السابقة، فقد يتفير كل شيء مع الإثراف البليل ويعود البحث لنقطة الصفر ؛ نتيجة الاختلاف بين الملدارس البحثية والعلمية للمشرفين.

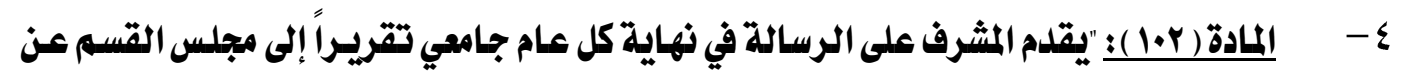


ملى تقدم الطالب في بحوثه ، ويُعرض هذا التقرير على مجلس الكلية، ولمجلس الدراسات العليا والبحوث بناءً على اقتراح مجلس الكلية إلفاء قيد الطالب على ضوي هذا التقارير" ، نصت هـده المادة على أداةوحيدة ( التقارير ) للتقويم المر حلي لمستوى تقلدم الباحث في رسبالته ، ولم تقلدم نهوذجًا لهذا التقرير ومعايير محددة واضحة للتقييه، كما أن التقيييم كل عـام فترة طويلة بـين التقييم والآخر، حيث إن المدة القانونية لالاتتهاء من إعداد رسالة الماجستير هي عـام واحلد مثلًا في معظم الجامعات، فكيف هذاء؛، كما أن إلفاء تسجيل الطالب في ضوي هذه الأداةومن خلال المشـرف في ظل حسالات تـوتر بعض العلاقتات الإثـرافية بـين بعض المشـرفين والبـاحثين عليـه تحفظـات وكثير من علامـات الاستفهام، كمـا لم يـرد بـنص المـادة آليـات لتحليـلـ الطرف المقصر ومحاسبته ، ومعرفة الأسباب حالة تأخر مستوى الإنجـازفي الرسسالة، كما ينبفي تحليـل جهاتة رسمية أو لجنة لمتابعة هذا التقارير ونتائجها ومصداقيتها ؛ حتى لا يكوز قرار المشرف تعسفيًا

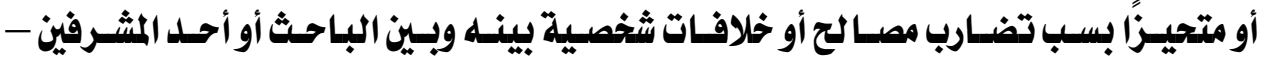
أحيانًا- وإن كان هذا لا يحلدث كثيرًا.

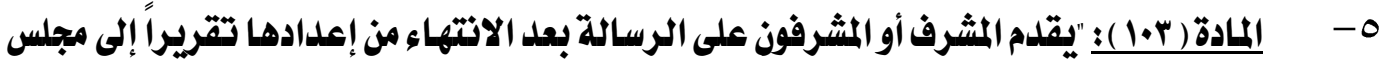
القسم المختص عن مدى صلاحيتها للعرض على لجنة الحكم مشفوعاً بـاقتراح تشكيل لجنة الحكم تقهيداً للعرض على مجلس الكلية وعلى الطالب أن يقدم إلى الكلية عدداً من النسخ تحددها اللوائح الداخليةة."، وبـالنظر لنص هـده المـادة يلاحظ أنها لم تنص على استشـارة الباحث في اختيـار المنـاقشين أو الممتحنين وأخدل رغبتهله بعين الاعتبـار، رغم أهميـة ذلك حتى لا تتعـارض المصالح سلبًا أو إيجابًا، وتُتخذ المناقشة سبيلًا للتشفي أو العكس الملديح المبالغ فيه ، كما غابت المعايير التي يتم في ضوئها اختياروتشكيل لجان المناقشة، وانفردت لجنة الإثراف بـاقتراحها، ورغم أن المادة نصت على "اقتراح"، إلا أن الواقع يقول أن لجنة الإشـراف هي التي ثُعين ومجلس القسم والكلية والجامعة يصدق على هلا التعيين دوذ معايير للاختيـار، فيكوز الاختياربـالأهواء والعلاقات الشخصية والمجاملة، وتتكرر نفس لجان المناقشة المتساهلة مرات ومـرات، ويُمنع من المناقثة الأستاذ الموضوعي، ومع وجود الأولى بـالتزامن مع ضعف الإثراف والباحث والرسالة، $=r 9 q$

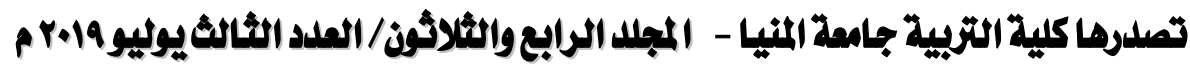
gamel_abdo59@yahoo.com

http://ms.minia.edu.eg/edu/journal.aspx 


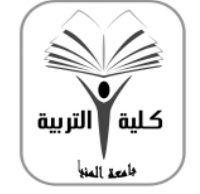

$$
\text { كجالة البحث في التزبية وملم النفسل }
$$

كايلة مُتملمدة من الميئة القومية لضمان جودة التمليم

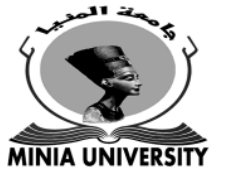

وغياب الثاني ينحلدر مستوى كثير من الرسائل العلمية وتقل جودتها.

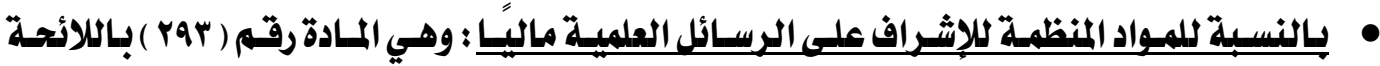
التنفيذية لقانون تنظيم الجامعات المصرية المُشار إليه :

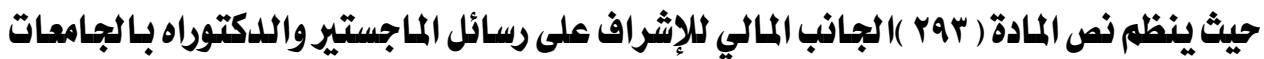

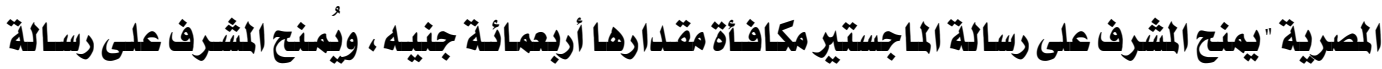

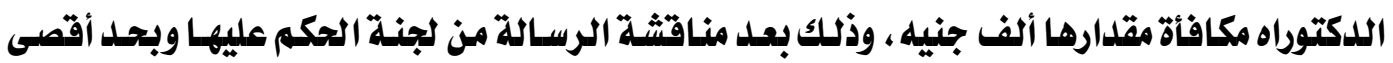
أربعة آلاف جنيه في السنة الجامعية، وإذا تعدد المشرفون وزعت المكافأة عليهم بـالتساوي"، يتضح من نص هذه المادة ضآلة المخصصات والمكافآت المالية للمشرفين مقابل الجهـل والوقت المبلذول في عملية الإثراف العلمي، حيثث تنص المـادة على مكافأة مقدارها ( ••؛ ) جنيـه للمشرف على رسـالة الماجستير، ومكافسأة

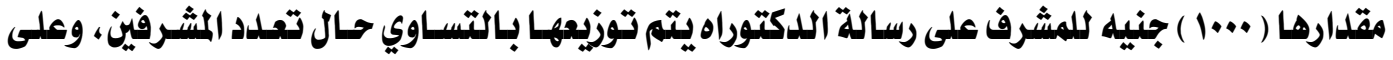
الرغم من التعليل التي الذي طرأ على هذه المادة بشأن زيادة المكافآت للمشرفين على الربسائل العلمية، إلا أنها ما زالت منخفضة بـالنسبة للجهل والوقت المبلؤل من عضو هيئة التدريس المشرف لفترات قدل تصل لاكثر من ثلاث سنوات قراءة وتعليلًا وتوجيهًا وإرشـادًا إلى غـير ذلك من إجـراءات حتى يمنح البـاحث الدرجة العلمية.

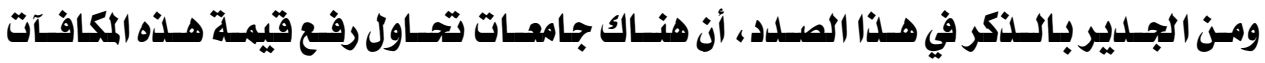
والمخصصات المالية وتضع بنودًا بلوائح الدراسـات العليـا أو تصدلدرقرارات بـدلك، فمثًا جامعة أسيوط،

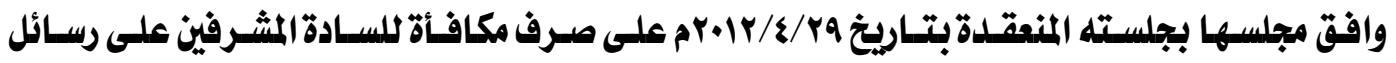
الماجستير والدكتوراة من صندوق البحوث بواقع (..1) ألف جنيه مصرى لرسالة الماجستير، و( ••10 ) ألف وخمسمائة جنيه مصرى لرسـالة الدكتوراه، وإذا تعلدد المشرفوز وزعت المكافأة بينهه بـالتسـاوي، هـدا

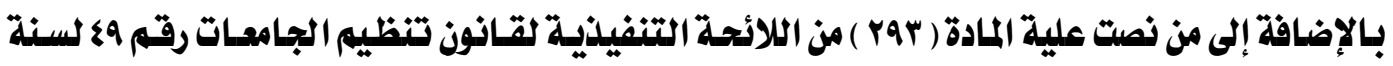

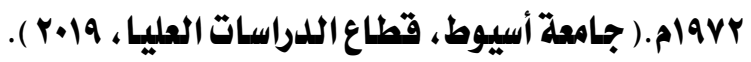

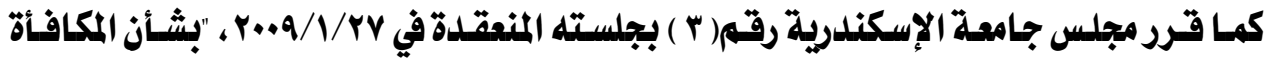
الخاصة بـالإثراف والمناقشة لرسـائل الماجستير والـلدكتوراه" ؛ حيث وافق المجلس على أن تكون المكافأة

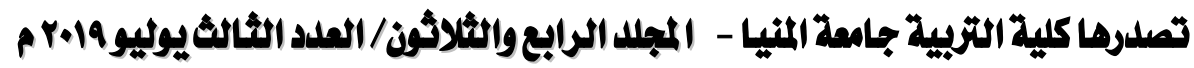
gamel_abdo59@yahoo.com

http://ms.minia.edu.eg/edu/journal.aspx 


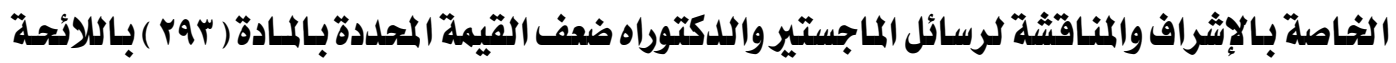

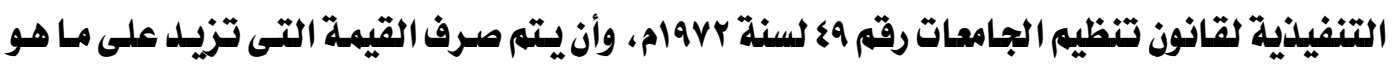
محسد بـاللائحة التنفيليــة من القـانوز المُشــار إليـه من صندوق الخدمة التعليميـة بـالجامعة والكليـات

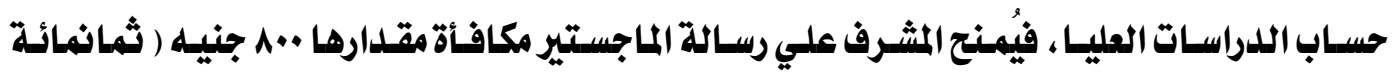
جنيه )، وذلك بعلد مناقشة الرسالة من لجنة الحكم عليها ، ويمنح المشرف علي رسالة الدكتوراه مكافـأة مقدارها .... ج جنيه ( ألفا جنيه ) وذلك بعل مناقشة الرسالة من لجنـة الحكم عليها، وإذا تعلدد المشرفوز وزعت المكافأة عليهه بـالتسـاوي، وللمشرف علي الرسالة أن يجمع بسين مكافـة فحص ومناقشة الرسسالة ومكافأة الإثراف عليها، علي أن يكوز الحد الأقصى للمكافآت ...1 جنيه ( ثمانية آلاف جنيه ) في العـام

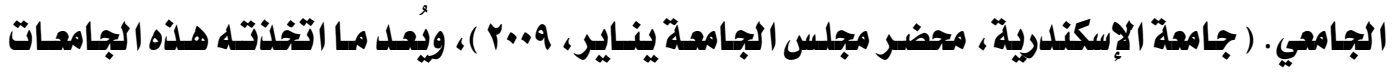
وغيرها خطوة على الطريق، إلا أن هذه المكافآت لا تزال ضيئلة مقارنة بجهود كثير من المشرفين المتميزين المجلين في إشرافهم على الرسائل العلمية، وأسوة بما يته بـالجامعات المتقدمة.

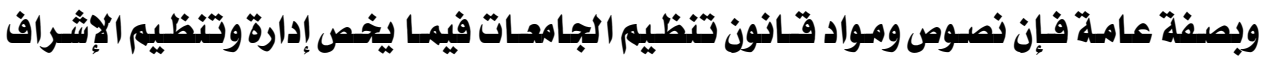
العلمي قد خلت من ذكر معايير لاختيار المشرفين على الرسائل العلمية، وإجراءات تعينهم واستبلدالهم أو

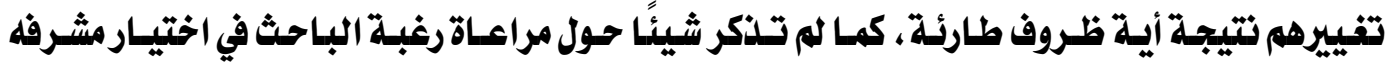
والعكس، كما خلت من تحليد أدوارومسئوليات واضحة للمشرف والطالب، ولم تضع ضوابط وقواعد تحكم العلاقة الإشرافية بينهما، كما لم يلذكر القانوز ولائحته التنفيذيـة شيئًا حول التنمية المهنية واشتراط حصول المشرف على دورات تدريبية في مجال الإشراف العلمي كمسوغات للتعيين وخاصة للمشرفين الجددد،

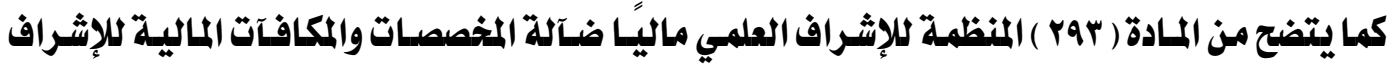
العلمي على رسائل الماجستير والدكتوراه بـالجامعات المصرية.

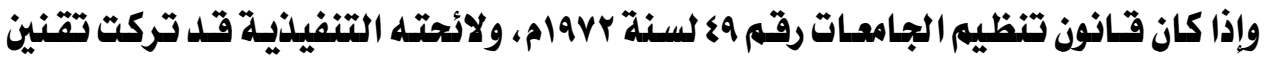

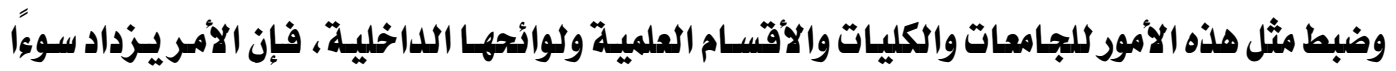
عندما تففل كثير من الجامعـات المصرية وضع قوانين وقواعلد وإصلدار قرارات مُحكمة وواضحة تنظظم الإشراف العلمي إداريًا وفنيًا وماليًا، وتتمسك وتطبق فقط بمـا جـاء في هـذا القـانوز ولائحته التنفيليـة $\varepsilon \cdot 1$

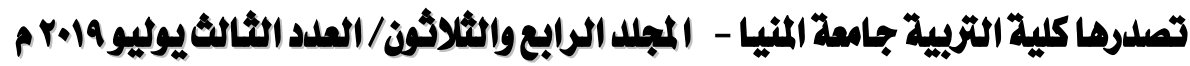
gamel_abdo59@yahoo.com

http://ms.minia.edu.eg/edu/journal.aspx 
على ما فيه من قصورونقص وعـوار تشريعي؛ ممـا يـؤثر في جـودة نظـام الإثراف على الرسيائل العلمية، ويؤدي إلى مخرجات بحثية ضعيفة في كثير من الأحيان، ولعل هذا ما توضحه النظرة الفاحصة ومطالعة معظم لوائح الدراسات العليا بـالجامعات المصرية وكلياتها وأقسامها الملمية والاككاد يمية في هذا الشأن، وتؤكسده نتـائج كثير من الدراسـات والبحـوث السـابقة في مجـال الإثـراف والبحث العلمي على مسـتوى الدراسات العليا بـالجامعات المصرية. فبمطالعة وفحص اللوائح الداخلية لقطاع اللدراسـات العليـا والبحوث لمعظم الجامعـات المصرية الحكومية عبر مواقعها الإككترونية الرسمية على الإنترنت ( جامعة المنيـا، أسيوط، سوهاج، بـي سويف، القاهرة، حلوان، جنوب الوادي، الزقازيق، الإسكندرية ...إلخ ) فيما يخص تتظيم وإدارة الإثراف على الرسيائل العلميـة، تبين للباحث أن معظم الجامعـات تحساول وضع شـروط وقواعـل للإشراف العلمي على الرسائل الجامعية بلوائحها الداخلية وبلوائح كلياتها وأقسامها العلمية في ضوء ما ينظمه قتانوز تنظيه الجامعـات ولائحتهه التنفيليـة المُشـار إليهـا سـابقًا، ومنهــا : ضـرورة ارتبـاط تخصص المشـرف بموضـوع الرسالة، وإسناد الإشراف لعضو هيئة تدريس من خسارج القسم أو الكلية أو الجامعة في حالة عـدم وجـود أستاذ متخصص في مجال وموضوع الرسالة، وتحليل علد الثشرفين على الرسالة حال التعلد بجيث لا يزيلد عن أربعة مشرفين كحد أقصى، ويمكن إضافة مشرف أجنبي في حالة الإثراف المشترك بالنسبة للدكتوراه، أما في الماجستير فلا يتجاوز عدد المشرفين بحال من الأحوال ثلاثة، ولا يجـوز اشتراك الملدرس في الإثـراف

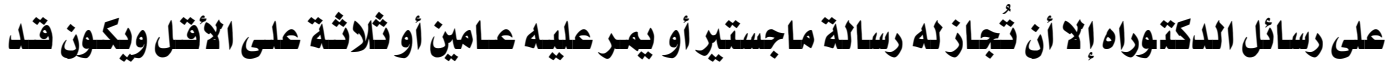
نشر بحث على الأقل في مجال تخصصه ، بـالإضافة لبيان حالات رفع المشرف من الإثراف كحسالات السفر والإعارة والاعتذار مع وضع بعض الإجراءات للذلك. كما أن معظم الجامعات وكلياتها تستخدم التقـارير السنوية ( كل عـام جـامعي )وأحيانًا نصف سنوي ( كل فصل دراسي ) من قبل المشرفين حول مستوى تقدم الطالب والتي في ضوئها قد يُلفى قيد الطالب حسب ما تقرره المجالس الر سمية وطبقًا لنص قـانون تنظيب الجامعـات ولائحته التنفيـذ سـابق الإثـارة إليه ، كما تضع معظم الجامعات إقرارات لعدم صلة قرابة المشرف بـالباحث حتى اللدرجة الرابعة، كما لا يجـوز اجتمـاع الأب والابـن أو الـزوج والزوجـة في الإثـراف على بـاحث كـإجراءات وسيـاسلة لعـدم تضـارب

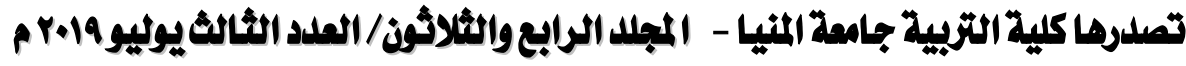
gamel_abdo59@yahoo.com

http://ms.minia.edu.eg/edu/journal.aspx 


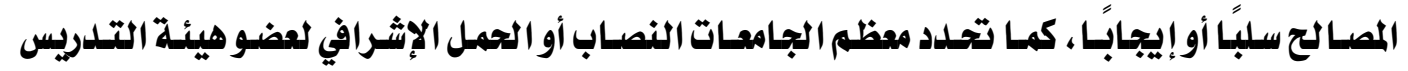
( الأستاذ، الأستاذ المساعد، المدرس ) بـألا يجتمع للدى كل عضو عدد معين من الباحثين في مرحلة الماجستير واللدكتوراه في نفس الوقت، وقد تختلف هذه الأعداد زيـادة أو نقصـان بـين الجامعـات وكلياتهـا أو داخل كليات الجامعة الواحدة. وتحاول كثير من الجامعات تطبيق قرارات بعلم اشراك عضو هيئة التـدريس على درجة ملدرس وأستاذ مساعل ( عامل أو متفرغ ) في الإثراف على الرسـائل العلميـة إذا تجـاوز ملدة سبع سنوات من تاريخ تعيينه في اللدرجة ولم يتقلم للترقية إلى اللدرجة التالية، كمـا تشترط بعض الجامعـات لإثراك الملدرس مشرفًا على رسائل الماجستير مرور عام على تعيينه في اللدرجة، وثلاثة أعـوام من تاريخ التعيين إجـازة رسالة ماجستير تحت إشرافه أو القيام بنشر بحث أو أكثر من أبحاث الترقية كثروط لإثرافه على رسسائل الدكتوراه، كما تحدد هذه الجامعات النصاب أو الحمل الإثـرافي لأعضـاء هيئة التـلدريس ( أستاذ، أستاذ

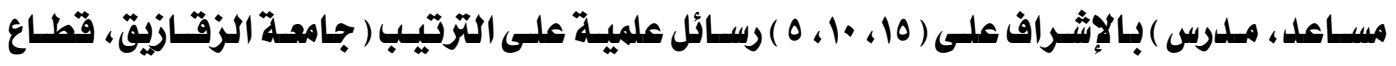

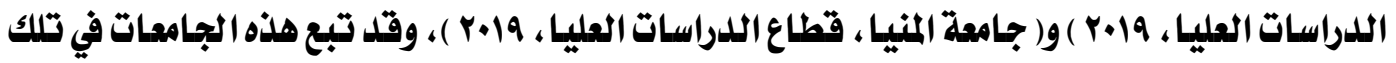
القرارات غيرهـا من الجـامعـات المصرية، وهنـاك من يـرى لهده القـررات إيجابيـات في مصلحة الإثـراف والبحث العلمي، والبعض الآخر يرى عكس ذلك.

ومن خلال العرض التفصيلي والتحليل النقدي للمواد المنظمة للإثراف العلمي - إداريًا وماليًا-

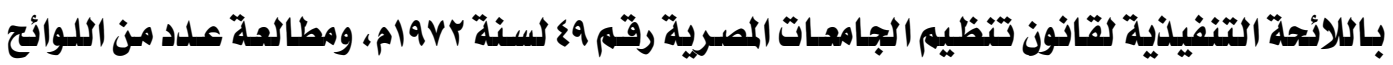
الداخلية للدراسـات العليـا لبعض الجامعات المصرية، يتضح ضعف تنظيه وإدارة الإثراف العلمي على الرسائل العلمية الجامعية، وملدى غموض وعمومية المواد والقرارات التي تنظم وتحكم اختيـاروتعييز المشرفين وتشكيل لجان الإثراف، وغيـاب التحليـل الدلديق والواضح لأدوارومسئوليات المشرفين، وقلة وجود ضوابط حاكمة للعلاقة الإشرافية بـين المشرف والطالب، وغياب أنشطة التنميـة المهنية وبرامجها كثرط لتعيين أعضـاء هيئة التـدريس في مجـال الإثراف على الرسسائل العلمية ، فتلك المواد واللـوائح لم تتضمن أكثر من إثـارات خاطفة تناقش العموميات وتترك كثيرًا من التفاصيل بلا تنظيه أو تحليـلـ ؛ مهـا أدى إلى ضعف وقصور نظام الإثراف على الرسائل العلمية بـالجـامعات المصرية وهـذا مـا تؤكده ملاحظـات

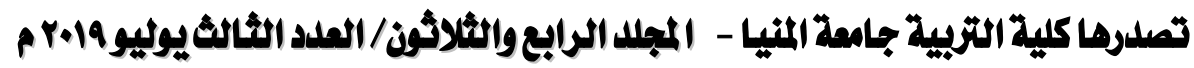
gamel_abdo59@yahoo.com

http://ms.minia.edu.eg/edu/journal.aspx 


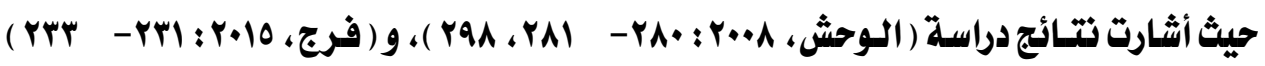

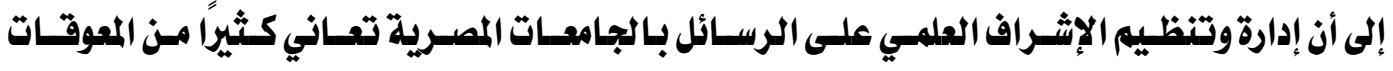
والسلييات، وأهمها : ضعف وضوح الأهداف الخاصة بعملية الإثراف، ونلرةو جود معاييز واضحة ومحلددة تسير في ضوئها أسوة بجامعات الدول المتقدمة، وقلة وجود معايير دقيقة يتثم في ضوئها اختيـار المشرف، وغياب التحليد الدقيق والواضح لأدواره ومسئولياته في الإثراف، وقلة وعي ومعرفة الطالب والمشرف

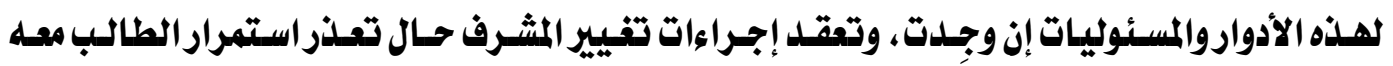
والعكس، وفي وغيرهـا من حسالات السفر والمرض والوفـاة. . .إلخخ وضعف وضـوح هـذه الإجـراءات بـالشكل الكافي وتعقدها مع كثرة وجود حالات تفيير وتبليل المشرفين؛ ممسا يـؤثر على استمرار البحث أو التـأخر والاخفاق أحيانًا في إنجاز الرسالة، بـالإضافة لعدم تتطابق الممارسات الإشرافية على أرض الواقع مع مـا تنص عليه اللوائح والتشريعات المنظمة، ناهيك عن ضآلة المستحقات والمكافآت المالية التي يحصل عليها الششرف مقابل جهلده وما يقضيه من وقت في عملية الإثراف والتوجيه للباحث، ومقارنة بمكانته ونظـيره في جامعات الدول المتقدمة.

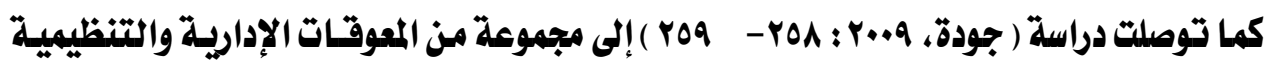
المؤثرة على جودة الإثرف على الرسائل العلمية بـالجامعات المصرية وكلياتها وأقسامها، منها : نلدرةوجود خطة إشرافية بـالكليات والأقسام الاككاديمية توضح قواعد الإثراف على الرسائل العلمية وتحلد ومعايير اختيار المشرفين أسس وقواعد تشكيل لجسان الإثـراف العلمي؛ ممـا يحرم شبـاب أعضـاء هيئة التدريس ( الملدرسين ) من الاشتراك في الإثراف العلمي، ونقص أعداد الكوادر الإثرافية المتخصصـة؛ ممـا يـؤدي إلى

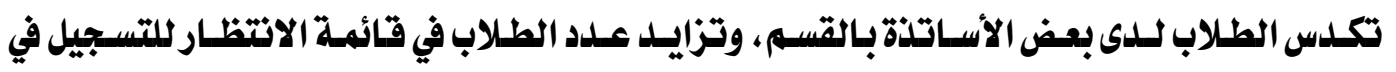
التخصصات التي بها عجز في الأساتدة المشرفين، بـالإضافة إلى كثرة غياب المشرفين أو سفرهم دوز توفير مشرف بلديل أو تيسير إجراءات تفيير المشرف ؛ومن ثم التأثير على جـودة العملية الإثرافية وعليه ضعف المخرجات البحثية من الرسائل العلمية.

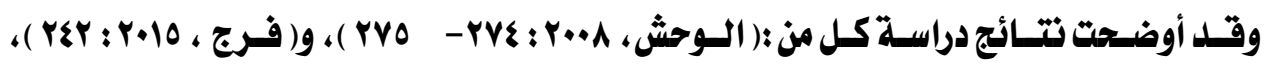
$\varepsilon \cdot \varepsilon$

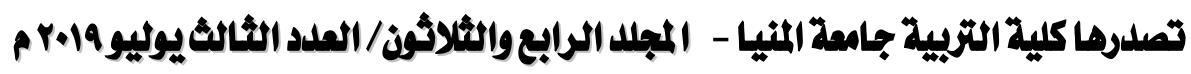
gamel_abdo59@yahoo.com

http://ms.minia.edu.eg/edu/journal.aspx 


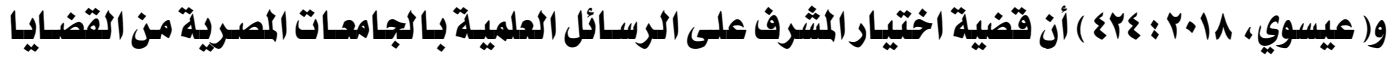
الشائكة والمثيرة للجدل ؛ حيث تتبنى معظم الجامعات سياسات لتعيين المشرف لا تسمح للطلاب والمشرفين في كثير من الأحيان بـالاختيـار، ويتم تمييز المشرف بحلول الدور عليه في الإثـراف دون الأخدذ في الاعتبـار رغبة واختيار الباحث للمشرف أو العكس، ودون مراعاة التوافق والانسجام بينهمـا ؛ حيث إن نظـام الدور

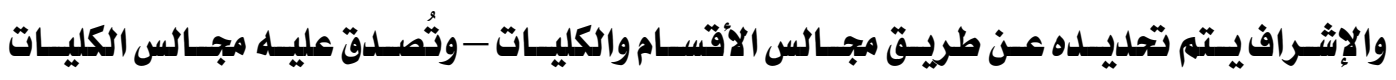
والجامعات- ولا يؤخد فيه برغبة الطابلاب الباحثين، وأحيانًا لا يؤخذ رأي المشرفين في اختيار الطالب أو فيمن يشاركه الإشراف من أعضاء هيئة التدريس ؛ فيصبح الطالب تحت إشراف أستاذ لايرغب فيه أو تحت إشراف أستاذين مختلفين فكريًا وثقافيًا - وأحيانًا- اجتماعيًا وإنسانيًا، وهلا يؤثر على سير الطالب

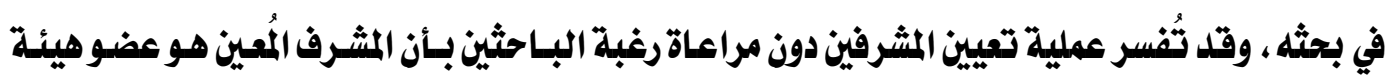
التدريس الوحيد بالقسم أو الكلية في الموضوع الذي اختاره الباحث، كما أن عملية اختيار الباحث لمشرفه يكتنفها كثير من الصعوبـات في طريقة التطبيق ومنهجية وقواعد التنفيذ من قبل مجلس القسيم والكلية، ولذا فثمث مواصفات ينبفي توافرها عند اختيار المشرف العلمي لتكوين علاقة إشرافية منتظمة بينه وبين باحثيه من أجل إنتاج بحوث ورسائل علمية متميزة.

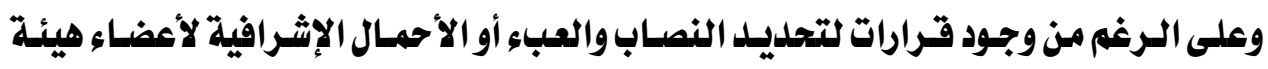
التدريس بمعظم الجامعات المصرية، إلا أن هنـاك ضعفًا في الالتـزام بـالنصـاب الإثـرافي لكل عضو هيئة

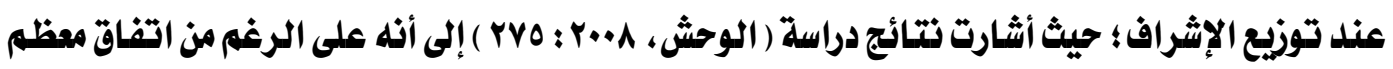

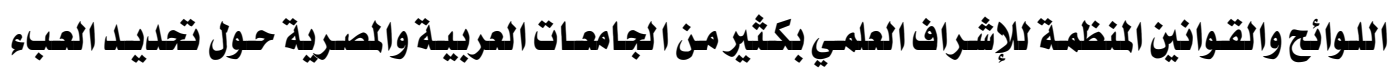
والنصاب الإثرافي لعضو هيئة التدريس -وإن اختلف النصاب من جامعة إلى أخرى- إلا أنه في كثير من الكليات والأقسام العلمية بتلك الجامعات يزيلد عدد الباحثين تحت إثراف الأستاذ عن النصساب المحلدد ؛ مما يؤثر على جودة العملية الإشرافية ومتابعة الباحثين وتوجيههم، ومن ثم التـأثير على جـودة المخرج

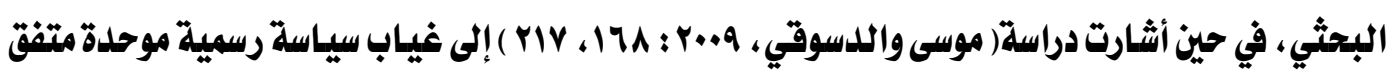
عليها بـالجامعات المصرية لتحديل عبي العمل الإثرافي ( النصاب أو الحِمل ) لكل عضو هيئة تلدربس، فهي تختلف من جامعة إلى أخرى ومن كلية إلى أخرى داخل الجامعة الواحلة. ، وقدل أوضحت دراسة ( عيسى، 10 ب ؛ 


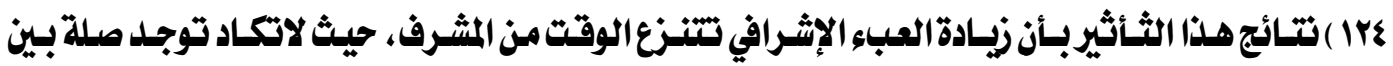
الأستاذ والطالب في كثير من الأحيان إلا نادراً، نظر لكثرة علد طلاب الدراسات العليا المسجلين تحت إشرافه.

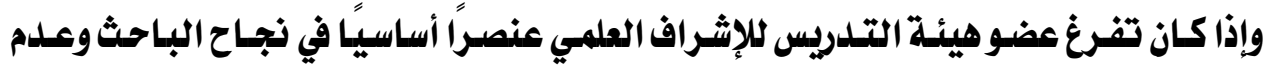
تأخره، إلا أن قضية التفرغ البحثي مسألة شائكة أمام كثير من الأعباء التدريسية والإداريسة التي تقع على كاهل الأستاذ المشرف، إضـافة إلى انتـلاب بعض الأسـاتذة إلى جامعـات أخرى، ناهيك عن الأعبـاء الإدارية المختلفة من اجتماعسات وأعمال الجـودةوالامتحانات والكنترولات ...إل ؛ ممـا لا يتيح للمشرف

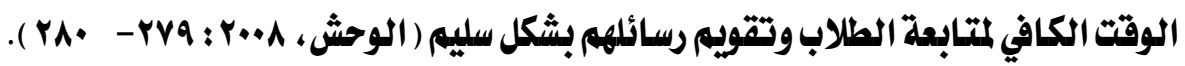
وحول واقع إدارة جـودة الدراسـات العليـا وتنظيم الإثـراف العلمي بـالجامعـات المصرية، أكلدت

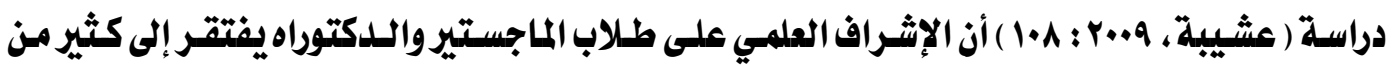
متطلبات الجودة، حيث إنه يواجه عدة مشكلات إدارية، أهمها : كثرة الأعباء الاكاد يمية والإدارية الملقـاة على عاتق أعضاء هيئة التدريس المشرفين على الرسائل العلمية خاصة في ضوي التفيرات الكثيرة الحادثة بالجامعات المصرية ؛ ممـا يـؤثر بـالسلب على مـا يقدمونه من جهـد في مجـال الدراسـات العليـا والإثراف

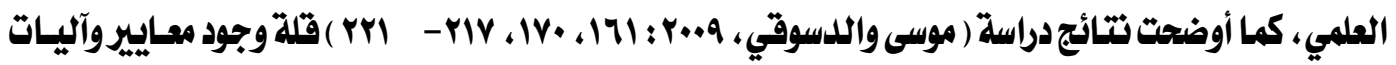
للإثراف العلمي بـالجامعات المصرية في ضوء أسس ومبادئ إدارة الجودة الشاملة؛ ؛تيجة قلت أو ندرة الدراسـات والبحوث التي حاولت الكثف عن هذذه الآليات وتطبيقها في الجامعات العربية عامة، وفي جامعات ومراكز البحوث العلمية في مصر خاصة، حيث أكلدت الدراسة على ضرورة اثتقال مبـادئ ومعايير الجـودة الشـاملة إلى

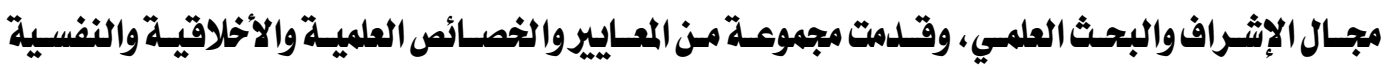

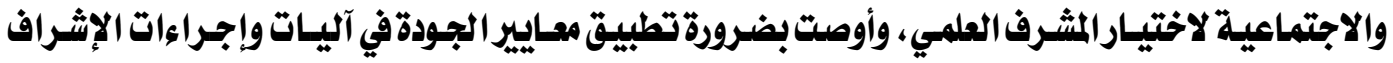
العلمي بالجامعات المصرية للتفلب على المشكلات الإدارية والتنظيمية التي يوا جهها.

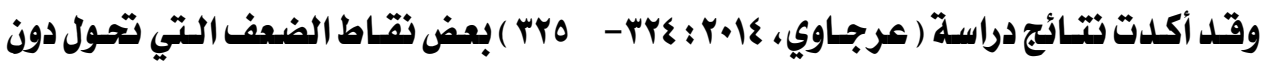
جودة إدارة وتظظيه الإثراف العلمي بـالجامعات المصرية، ومنهـا : الاستعانة بمشرفين غير متخصصين في مجال الرسالة من كليات وأقسام أخرى ؛ مما يترتب علية حدوث متاعب ومعوقات بـالفة للباحثين، وتميين المشرفين على رسائل الماجستير واللدكتوراه دوذ رغبة واختيار الباحثين الأمر الدذي يترتب عليه انخفـاض 


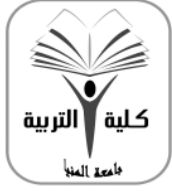

\author{
مجالة البجث في التزبية ومام النفس \\ كايلة التزبية - جامعة المياتيا
}

كايلة مُتملمدة من الميئة القومية لضمان جودة التمليم

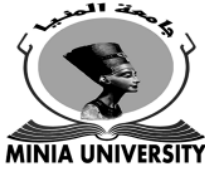

مستوى دافيـتهم للإنجـاز، بـالإضـافة إلى السماح بسفر المشـرفين قبـل استكمال الرسـائل التي يشرفون عليها ، ودون وضع إجراءات محددة لتعييز البديل المناسب.

وأمـا فيمـا يخس إدارةوتنظيـيم الجوانب الماليـة للإثـراف على الرسـائل العلميـة بـالجامعـات

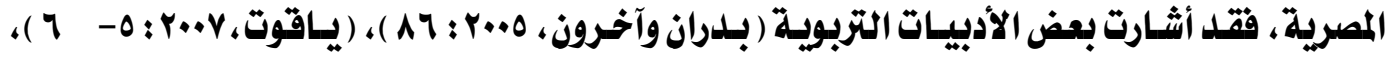

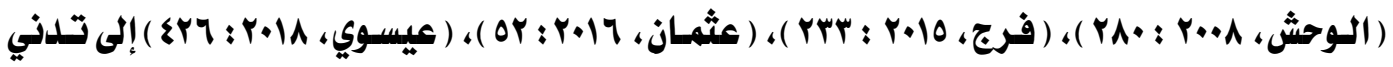
الاعتمادات والمخصصات المالية للمشرفيز على الرسـائل العلمية الماجستير والـدكتوراه ؛ نتيجة انخفـاض مستوى الإنفاق على البحث العلمي بـالجامعـات المصرية ؛ مهـا أدى إلى ضعف تلك المخصصـات والمكافآت الماليـة، وضعف الحسافز المـادي والمعنـوي السلدي يحصل عليه الأستاذ المشرف في مقابـل جهوده في عمليـة الإشراف العلمي وفي ظل تدذي مرتبات أعضاء هيئة التدريس ؛ ومن ثم تصنع هلده الظروف والعوامل مناخًا لا يشجع كثير من أساتلة الجامعات المصرية على القيام بأدوراهم في الإثراف والبحث العلمي والإتتاج والإبـلـاع بشكل متميز، نتيجة انشفال بعضهم بمصادر أخرى لزيـادة الدخل ومواجهة تكماليف الحيـاة وأعبائها، كمـا أن البعضيعزفوز عن الإثراف العلمي المرهق في مقابل تفطية ساعاتهم التدريسية بمقررات دراسية - إن أمكن ذلك- وهذا بلدوره يؤثر على جودة البحث العلمي الإثراف على الباحثين في ظل تزايلدهم المستمر وضعف معاير اختيارهم وانتقائهم.

ومما سبق، يتضح واقع إدارة وتنظيم الإثراف العلمي بـالجامعات المصرية ومـا يشوبه من أوجهـ قصوروجوانب ضعف متعددة ومتنوعة ترتبط بعناصر المنظومة الإدارية للدراسات العليـا والبحث العلمي بتلك الجـامعـات، تراكـة أثرهـا السـلبي في المخرجسات بحثيـة من رسـائل علميـة على مسـتوى الماجستير والدكتوراه معًا.

ثانيًا : واقع أدوارومسئوليـات الإشراف العلعي بـالجحامعات المصرية : على الرغم من أهمية الإشراف العلمي في إعداد رسائل الماجستير والدكتوراه بـالجامعات المصرية، إلا أن بعض الدراسات تشـير إلى قصهور دور لجـان الإثـراف العلمي على هـذه الرسـائل عن القيـام بههامهـا

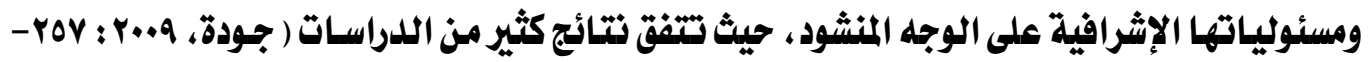

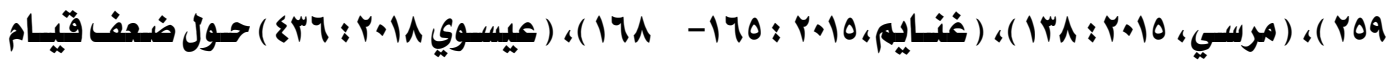
$\varepsilon \cdot V$

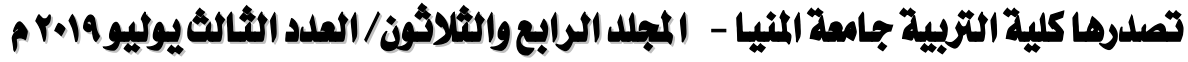
gamel_abdo59@yahoo.com

http://ms.minia.edu.eg/edu/journal.aspx 
كثير من المشرفين بـالأدواروالمسئوليات الإشرافية المتوقفة تجاه بـاحثيهم من توجيه ومتابعة ومسـاعلة في إنجاز رسالته، وقد أرجعت هذا اللدراسات ذلك الضعف إلى : قلة وعي ومعرفة بعض المشرفين بهذه الأدوار والمسئوليات، وضيق وقت المشرفين في ظل كثرة الأعبـاء التدربسية والإداريـة التي يقومون بها، وكثرة وتضخم علد الباحثين للدى المشرف الواحلد، وانشفال بعض أعضساء هيئة التـدريس المشرفين بـالأمور الحياتية ومواجهة أعبـاء الحيـاة، بـالإضـافة إلى ضعف تقكن بعض المشرفين - المبتـلئين- من تخصص وموضـوعات الرسـائل الـتي يشـرفوز عليهـا ؛ ممـائشعف عمليـات المتابعة والتوجيـه للبـاحثين وإهمـالهم، وفرض الآراء والموضوعات البحثية من قبل المشرفين، وقلة مناقشة البـاحثين والاستماع إلى آرائهم ووجهات نظرهم، ومما نتج عنه ضعف جلية بعض الشرفين في عملية الإشراف على الرسائل العلمية بشكل عام.

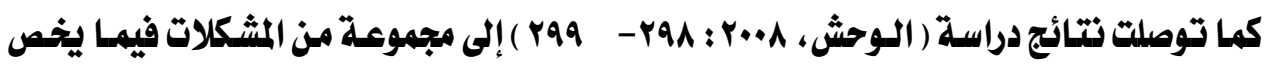
ضعف قيام كثير من المشرفين بـأدوارهم ومسئولياتهم الإشرافية تجاه الباحث، تثثلت في : ضعف استفادة الباحثين من المشرفين ؛ نتيجة قلة الخبرة البحثية لـلى بعض المشرفين، وترك الباحث يعمل بمفرده دون توجيه ومتابعة وتدريب، وقلة قرائة محتـوى البحث بلدقة ، وعلدم الحكم بموضوعية على مـا أنجزه الباحث في بحثـه ، بـالإضـافة إلى قلت الوقت المخصص للإثـراف على البـاحثين، وعـلم تخصيص لقـاء أسبوعي لمقابلـة البـاحثين، مـع ضعف التـزام بعض المشرفيز بـالسـاعات المخصصـة لـذلك في جـداولهم

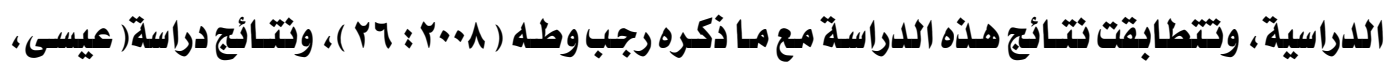

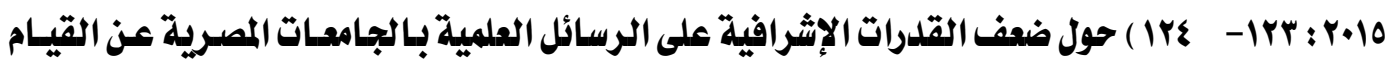
بـأدوارها ومسئولياتها على الوجه المطلوب؛ نظرا لقلة الأسـاتلة المؤهلين والمتفـرغين للإثـراف على تلك الرسائل، وتتيجة للنمو المتزايـلد في أعلداد طلاب اللدراسـات العليـا وزيـادة ذسبة المسجلين منهم للدرجات الماجستير والدكتوراه ؛ مما أدى بلدوره إلى زيـادة عدد الطلاب المسجلين مع مشرف واحلد بعينه ، وهـذا أدى إلى انخفـاض المستوى العلمي الـذي تخـرج بـه الرسـائل في ظل قلـة الأسـاتلة، وزيـادة أعبـاء أعضساء هيئة التدريس المثرفين التي تتنتزع كثيرًا من وقت الإثراف؛ حيث لا تكاد توجلد صلة بـين الأستاذ والطالب في كثير من الأحيان ، إضافة إلى قلة التزام بعض المشرفين ببعض الأدواروالمسئوليات الأساسية المتوقعة منهه مثل : المساعدة في اختيار موضـوع البحث، التوجيه لحضور المؤتثرات والندوات، وضع مخطط زمني كلي 
لكلانتهاء من الرسالة....إلخ.

ومن ثم يتلخص واقع أدوارومسئوليات الإثراف العلمي في ضعف قيـام بعض المشرفين بتلك الأدوار والمسئوليات الإثر افية ؛ تتيجة قلة الوعي والمعرفة بها في ظل غيساب التحليـد الواضح والدقيق لهـا، وضيق وقت الثشرفين، وكثرة الأعباء التدريسية والإدارية التي تتنتزعوقت الإثراف مع تزايلد وكثرة أعداد البـاحثين وقتلة تقرغ المشرفين.

ثالثًا : واقع العلاقة الإشرافية بين المشرف والباحث بـالجامعات المصرية: تكوين علاقة إثرافية ناجحة بـين الأستاذ المشرف والطالب الباحث من أهم مقومـات النجـاح للعملية الإشرافية في إعداد بـاحث مبلدع وإنجاز رسالة علمية متميزة، وعلى الـرغم من ذلك تشير نتـائج

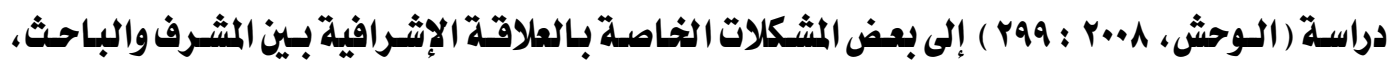
أهمهـا : قلة الأخدل بـرأي البـاحث في موضهوع البحث، وفرض الآراء عليه في اختيـار موضـوع البحث طبقًا لاستعداد وتخصص وقدرات المشرف وليس استعدادات وقدرات الباحث، وقلة تقبل بعض المشرفيز لأعلدار الباحثين وظروفهم الخاصة والطارئة، وغضبهم من كثرة تساؤلاتهه، كما أن الأمر يزداد سوءًا حال تعلد المشرفين ؛ مما قد يؤدي إلى تفيير فصول البحث ومحتواه، اختلاف المشرفين في الرأي أو خلافاتهم حول بعض القضايسا والذي يمتد تأثيره على الحالة النفسية للباحث فيتوقف أحيانًا نتيجة إخفاقه في التوفيق بين جميع الآراء وخاصة عند تقسك كل مشرف برأيه .

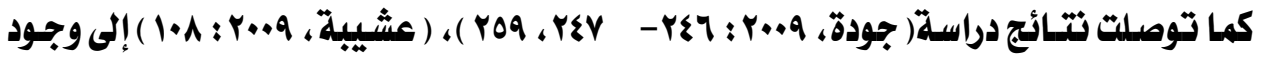
قصوروفتور في بعض جوانب العلاقة الإثرافية بـين طرفي عملية الإثـراف ( الأستاذ المشرف، والطالب الباحث )، فمن جانب الباحث يتمثل سوء العلاقة في محاولات الاستفلال أو اللجسوي لبعض الحيل لكسب ود

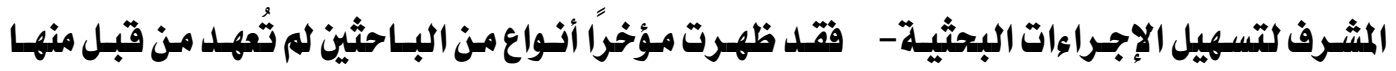
( الباحث الفهلوي، والباحثة اللعوب )، وأما بـالنسة للأستاذ المشرف فتتمثل صور توتر العلاقة الإثرافية في عمليات التلخل السافر في توجيه الباحث وفرض الرأي وعلدم التعـاون في مناقثة أفكار البحث وقلة احترام وجهة نظر الباحث - وتسفيهها في بعض الأحيان- والتقليل منها، واستفلال بعض المشرفين لمجهودات الباحث وقوة عمله البحثي وتقكنه ومهاراته في أداء بعض الأعمال والمهام الخاصة بـالمشرف

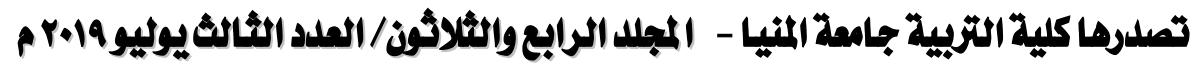
gamel_abdo59@yahoo.com

http://ms.minia.edu.eg/edu/journal.aspx 


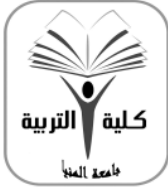

$$
\text { مولة البعث في التربية وعلم النفس التربية - جامعة المنيا }
$$

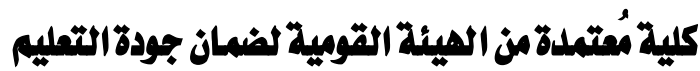

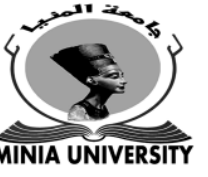

نيابة عنه أو استفلال المادة العليية الخاصة بالباحث لصـالح الشرف ؛ مما ينعكس سلبيًا على شخصية الباحث العلمية والخُلقية، بالإضافة إلى تعكير صفو العلاقة الإشرافية. ونتيجة لتعدد المدارس البحثية والرؤى والاتجاهـات في مراحل البحث والإثراف العلمي تعدذاً وصل لمرحلة التعارض والاختلاف، وصلت رسسالة ضمنية يتعامل في ظلها البـاحثون، ألا وهي أن الرسالة العلمية تساوي "الثرف" بععنى أن الباحث عليه أن يسمع ويطيع مشرفه بصرف النظر عن رؤيته البحثية.

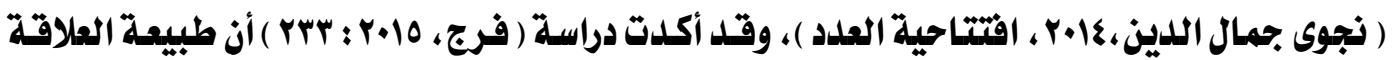
الإثرافية بالجامعات المصرية تتسم بعدم الوضوح والتحليل، وأن معظم مشكلات الإثراف العلمي ترتبط بطبيعة هذه العلاقة التي لا تخضع في معظم الأحوال لنمط محدد، حيث إنها تخضع لظروف صعبة معقدة ومتفيرة، وتتسم بعلدم وضوح الضوابط والإجراءات المنظمة لها.

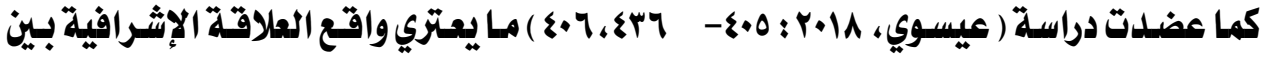
الأستاذ والباحث من ضعف وقصور، ناهيك عن توتر تلك العلاقة الإثرافية النفسية والاجتماعية؛ نتيجة تحيز بعض المشرفين وتعصبهم لآرائهم وخاصة حال تعدد المشرفيز على الرسالة، وضعف التعاون بين الشرف والباحث وتقاسم مسئولية إنجاز الرسالة، وشكلية لجسان الإثراف العلمي على البـاحثين في بعض الأحيان ؛ مما أدى إلى ضعف جودة الرسائل العلمية، وتفشي السرقات العلمية بين صفحاتها، وضعف

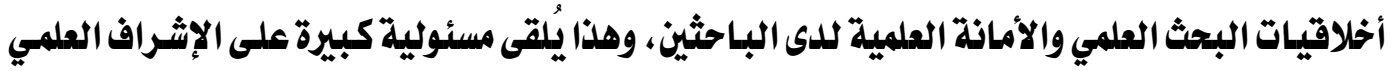
ولجانه في إكساب الطلاب أخلاقيات البحث العلمي والمهارات البحثية، ولعل مرد ضعف العلاقة الإثرافية بين الأستاذ والباحث بشكل غير مباشر قد شكله المناخ الجامعي والعلمي والبحثي الدي تعيشه الجامعات المصرية؛ مما يتطلب إعادة النظر في منظومة الدراسات العليا والبحث العلمي بالجامعات المصرية وخاصة

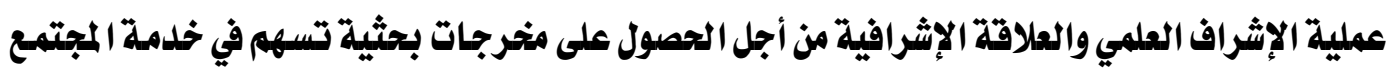

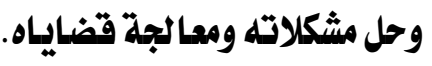
ومما سبق، يتضح أن العلاقة الإثرافية بين المشرف والباحث بالجامعات المصرية يشوبها كثير من

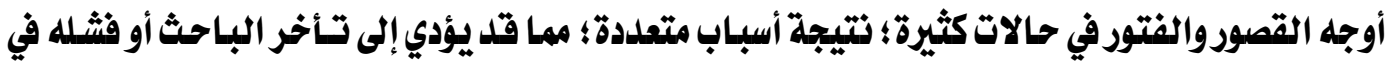
إنجازمشروعه البحثي أو الاتتهاء منه بشكل غير صحيح.

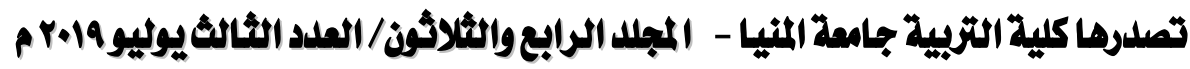

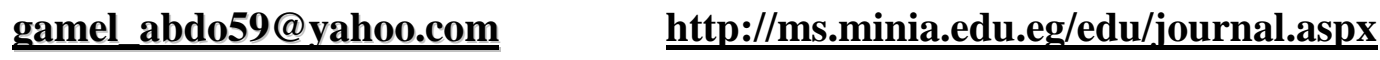




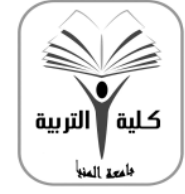

\author{
مجلة البعث في التزبية وعلم النفس \\ كالية التربية - جامعة المنيا
}

كلية مُتملدة من الهيئة القومية لضمان جودة التعليم

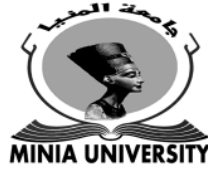

رابعًا : واقع التنمية المهنية لأعضاء هيئة التدريس بـالجامعات المصرية في مجال الإشراف العلمي:

على الرغم من اهتمام الجامعات المصرية بتنمية قدرات أعضاء هيئة التدريس كأحد مشروعات

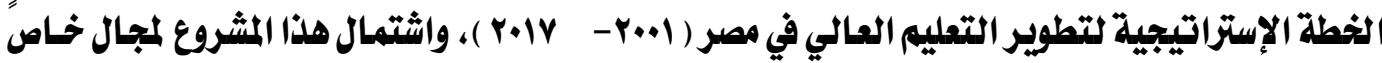
بالبحث العلمي، ووجـود المركز القومي لتنمية قدرات أعضـاء هيئة التـلريس والقيـادات وفروعه بكل

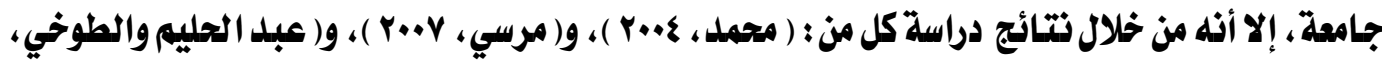

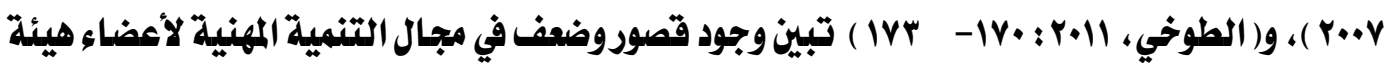
التدريس بالجامعات المصرية بصفة عامة وفي مجال الإثراف والبحث العلمي بصفة خاصة ، فعلى الرغم

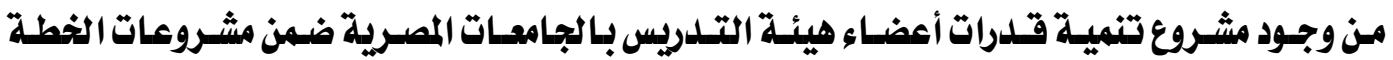
الإستراتيجية لتطوير منظومة التعليم العـالي في مصر ؛ بهلدف التنمية المهنية لأعضاء هيئة التدريس

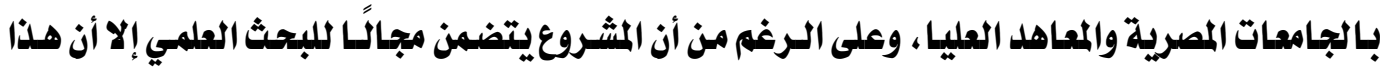

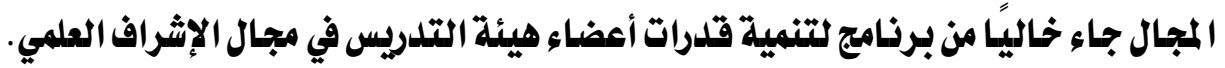
ولعل هذا ما تؤكده النظرة الفاحصة لما تقدمه معظم مراكز تنمية قدرات أعضاء هيئة التدريس بالجامعات المصرية ومراجعة مجـال البحث العلمي من هذا المشروع وما يتضمنه من بـرامج هي ( النثر الدولي للبحوث العلمية، إدارة الفريق البحثي، إدارة مشروعات البحوث التنافسية، أخلاقيات البحث العلمي )؛ حيثيفيب عنها برنامجًا لتنمية وصقل مهارات أعضاء هيئة التدريس - لاسيما الجدد والمبتدئين - في مجال الإثراف العلمي. ( المركز القومي لتنمية قدرات أعضاء هيئة التدريس والقيادات، 19. 19 ).

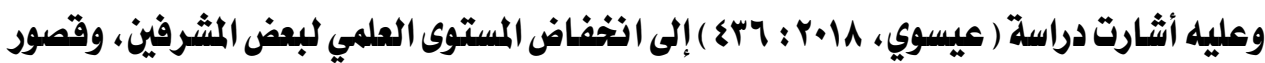
المتابعة المستـمرة للجديـلـ في مجـال الإثـراف العلمي والتخصص أو في النقـاط البحثية للطلاب الـلين

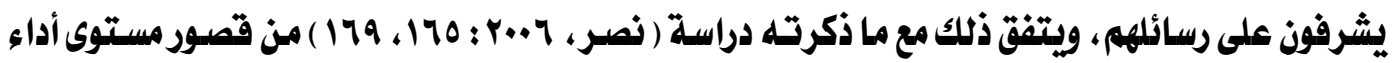
بعض أعضاء هيئة التدريس المشرفين على الباحثين ورسائلهم العلمية، وحاجة بعضهم إلى تنمية قدراتهم

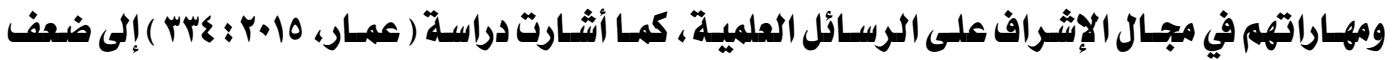
القدرات الإشرافية للد الشرف العلمي وأثرها على ضعف تنمية مهارات البحث للدى طلاب الدراسـات العليا، ووصول كثير من رسائل الماجستير والدكتوراه إلى مرحلة المناقثة وهي محملة بالعديد من الأخطاء \&11

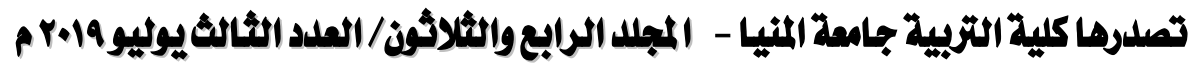
gamel_abdo59@yahoo.com

http://ms.minia.edu.eg/edu/journal.aspx 
والملاحظات التي ترهق المناقشين أثناء القراءة والمناقشة لتعليلها، وقد أرجعت الدراسة ذلك إلى قصور التنمية المهنية لأعضاء هيئة التدريس في مجال الإثراف العلمي، ومن ثم أوصت بضرورة الاهتمـام بعملية تلدريب المشرفين ومساعديهم من أجل تنمية قدراتهم البحثية والإثرافية، وذلك من خلال ورش العمل واللدورات التدريبية والندوات العلمية.

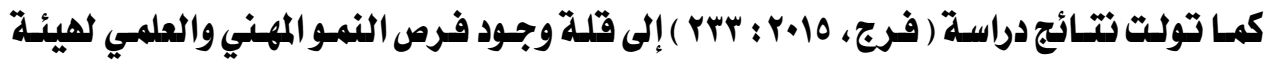
الإثراف على الرسائل العلمية من مؤتقرات وندوات ودورات وبعثات وورش عمل ذات صلة وثيقة بمجـال الإشراف العلمي، بـالإضافة إلى قلة الاهتمام بتنمية مهارات وقدرات أعضاء هيئة التلدريس في هذا المجال المهم من قبل الجامعات والكليات والأقسام العلمية، وقد أدت قلة الاهتمام بـالتنمية المهنية لأعضاء هيئة التـلدريس في البحث العلمي ومجـال الإثـراف العلمي خاصـة إلى غيـاب العقل العلمي، وتعميـق التبعيـة والخضوع بحيث لا يتبقى إلا النقل والتقليد ؛ مما أضعف إسهامات الجامعات في البحث العلمي، وانخفـاض إنتاجية الباحثين كمًا ونوعًا.

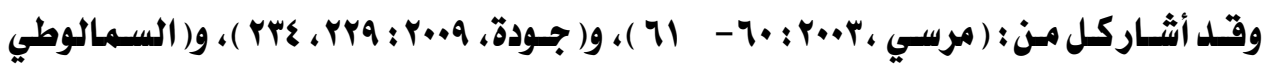

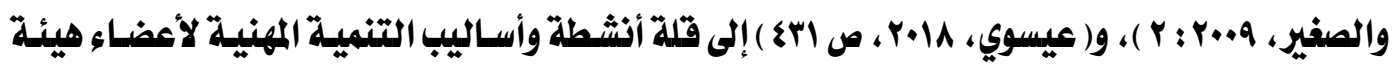
التدريس والطلاب في مجال البحث والإثراف العلمي داخل كثير من الجامعات المصرية كلياتها ؛ تتيجة قلة

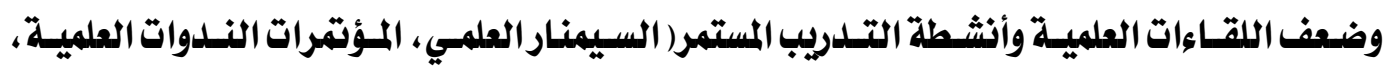
والبرامج والدورات التدربية، ورش العمل. ..إلخ )، وعلدم الاهتمام بهذه الأنشطة كأساليب للتنمية المهنية لأعضاء هيئة التدريس والمشرفين والطلاب على حلد سواء، وضعف تنظيهها ومحتواهـا، وشكلية انعقادهـا وجحود أهدافها، وقلة إثباعها لمتطلبـات التنمية المهنية في مجال البحث والإثراف العلمي ؛ مما جعل الأساتدة والطلاب يعزفوز عن حضورها والمشاركة فيها. وذلك على النقيض في جامعات الـدول المتقدمة؛

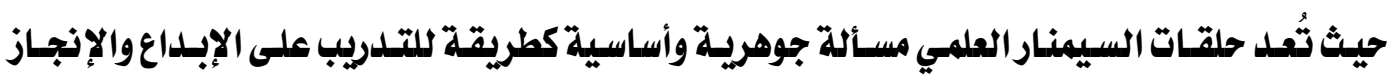
والبحث والتأليف الملمي.

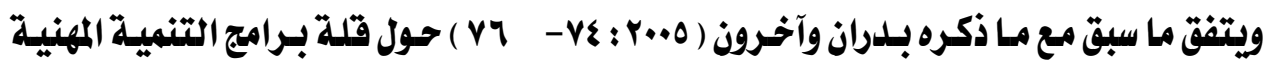
لأعضاء هيئة التدريس في مجال البحث العلمي والإشراف ؛ بـالإضافة إلى ضعف تنظيه الدورات والبرامج \&Ir

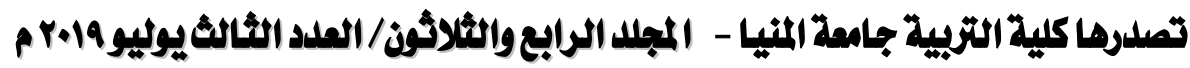
gamel_abdo59@yahoo.com

http://ms.minia.edu.eg/edu/journal.aspx 
التدريبية في المجال البحث العلمي، وا ذحسار فرص التحفيز، وضعف الاحتكاك الخارجي الدولي من خلال البعثات والإثراف المشترك، وقصور البيئسة البحثية والمنـاخ العلمي الجـامعي الداعم للتنمية المهنيـة في

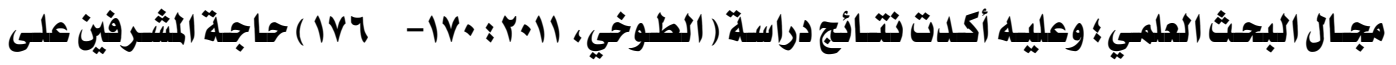
الرسائل العلمية بـالجامعات المصرية إلى التنمية المهنية، وكانت أهم احتياجساتهم التدرببية تتمثل في : المعرفـة الكافيـة بـاللوائح والقـوانين الـتي تحكم الإثـراف العلمي، وتعــف طبيعـة الإثـراف العلمي وأخلاقياته والعوامل المؤثرة فيه، والاطلاع على الاتجاهات العالمية في مجال الإثراف العلمي وأسـاليبه الحليثة، ومعايير جودته ؛ ومن ثم اقتر حت الدراسة مجموعة من الأنشطة والوسائل والمقتر حسات للتنمية المهنية ورفع كفاءة أعضاء هيئة التدريس بـالجامعات المصرية في مجال الإثراف العلمي. وفي ضوء استعراض واقع الإثـراف العلمي بـالجامعات المصرية ووضعه الـراهز من خلال تحليل التشـريعات والسياسـات والقـوانيز المنظمهة لــه، ومطالعـة وفحس اللـوائح الداخليـة لـبعض الجامعـات المصرية، ومـا رصـدته البحـوث والدراسـاتوالأدبيـات التربويـة المعاصـرة، يتضـح أن نظـام الإثـراف العلمي

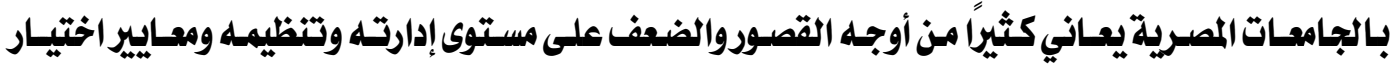
المشرفين وتشكيل لجان الإثراف، وغموض أدوارومسئوليات المشرفين على الرسـائل العلمية، وقصور العلاقة الإشرافية بين طرفي عملية الإشراف ( الأستاذ/ الباحث )، بالإضافة لضعف الاهتمام بالتنمية المهنية لأعضساء هيئة التدريس في مجال الإشراف العلمي وقلة وجود برامج وأنشطة تدريبية في هذا المجال. ومن الجدير بـالذكر أن أحكام هذا الواقع لا يمكن تعميهها بصفة قطعية مطلقة، فهنسك نهـاذج كثيرة متميزة من أعضاء هيئة التـلديس المشرفين على الرسـائل العلميلة بـالجامعـات المصرية، من حيث :

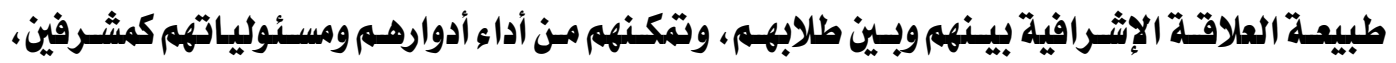
بـالإضـافة إلى الخبرة والـتمكن والسمعة العلميـة في مجـال البحث والإثـراف العلمي، ولعل معظم أوجـه القصور في نظام الإشراف العلمي بـالجامعات المصرية تعود إلى جمـود الإدارة وتقادم التشريعات المنظمة وقلة توافقها مع التقلدم الحادث في مجال البحث العلمي بمجالاته المختلفة، وضعف مواكبتها لما هو مُطبق ومُعمول بـه في الجامعـات المتقدمة، بـالإضـافة لقلة خبرة بعض المشرفيز وخاصة بعض الجـد المبتـدئين؛ نتيجـة غيـاب الإعـلـاد والتـلدربب والتنميـة المهنيـة، ناهيـك عـن المشـرفين غـير المتخصصـين في مجــال 
وموضوعات الرسائل التي يشرفون عليها، أو المتخصصين ممن لا يسعون لتنمية البعد المعرفي الخاص بتلك الموضوعات، ناهيك عن ضعف مستوى بعض الباحثين وعلم تحملهم مسئولية المشـاركة في إنجـاز الرسسالة بالشكل الكافي والمناسب، فقد يكون الطالب وإمكاناته وقدراته العلمية والبحثية ، ومستوى دافيتهل للإنجاز والبحث، ومسئولياته وأعبائه الاجتماعية والمادية، وقلة معرفته بـأدوراه خلال مراحل البحث في ظل معايير انتقائية ضعيفة من الأسباب الرئيسة وراء الإنتـاج البحثي الضعيف وليس لجنـة الإثراف وحدها، فالأمر قد يكون مشترك، وله عوامل ومسببات ومتفيرات أخرى غير المشرف والباحث. وعلى ضوء هذا الواقع والوضع الراهن للإشراف على الرسائل العلمية بـالجامعات المصرية، حاول البحث استعراض خبرات ثلاث من الجامعات الأجنبية المتقدمة والرائدة في مجال البحث والإثراف العلمي على طلاب اللدراسات العليا، وذلك في ضوء حلدود البحث الموضوعية ومحاوره، ثم إجـراء التحليل المقـارن

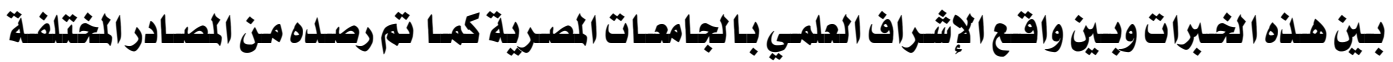
السابقة؛ لاستخلاص أوجه الاستفادة التي يمكن الارتكاز عليها في بناء الرؤية المقترحة لتطوير الإثراف العلمي بـالجامعات المصرية، وذلك كما توضحه المحاور القادمة من البحث. المهور الرابع: خبرات بعض الجاهعات الأجنبية في هجال الإشراف العلهي (دراسة وصفية): يقلدم هذا المحوروصفًا لنظام الإثراف العلمي بثلاث جامعات متقدمة من قـارات مختلفة هي: جامعة أكسفورد بـانجلترا في قارة أوربـا، وجامعة نيـو سيوث ويلز بسيدني في أستراليا، وجامعة أوكالاند

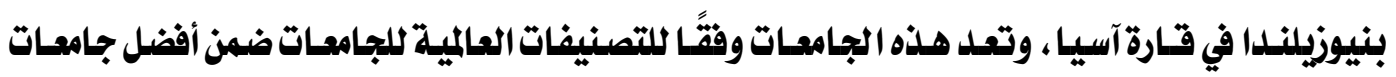
العالم ؛ حيث تحتل مراتب متقدمة في كثير من التصنيفات المتترف بها عالئياً (تصنيف شنفهاي، وتصنيف كيو أس "QS" ، التيامز البريطاني )، حيث تناول المحور الإشراف على الرسائل والبحوث العلمية لطلاب الدراسـات العليا بتلك الجامعات من حيث: إدارته وتتظيمه ، ومعايير اختيـار المشرفين وتشكيل لجسان الإثراف، وأدوار ومسئوليات طرفي عملية الإثراف ( الأستاذ الشرف/ الطالب الباحث )، والضوابط الحاكمة للعلاقة الإثرافية بينهـا، وأسـاليب وأنثطة التنميـة المهنيـة لأعضساء هيئة التـلدريس في مجـال الإشراف العلمي، وذلك بكل

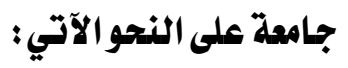

\section{$\varepsilon 1 \varepsilon$}

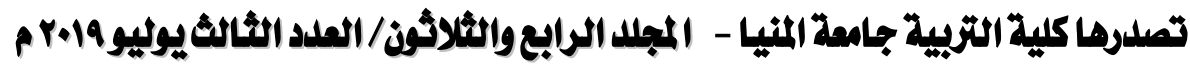
gamel_abdo59@yahoo.com

http://ms.minia.edu.eg/edu/journal.aspx 


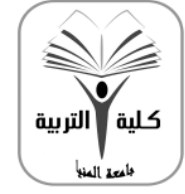

$$
\begin{aligned}
& \text { مجلة البعث في التربية وعلم النفس } \\
& \text { كلية التربية - جامعة المنيا }
\end{aligned}
$$

كالية مُشتمدة من الهيئة القومية لضمان جودةالتمايليم

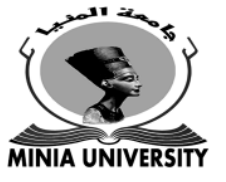

أولًا : الإشراف العلي بجامعة أكسفورد بِإنجلترا:

تعد جامعة أكسفورد The University of Oxford مركزًا رائدًا للتعليه والتعلم والبحث العلمي، وأقدم جامعة في العالم الفربي الناطق بالإنجليزية، وأقدم جامعات بريطانيا السبع العتيقة، والجامعة الأولى في المملكة التحدة،، وتقع الجامعة في ملينة أكسفورد، وترجع أصولها على أقل تقلير

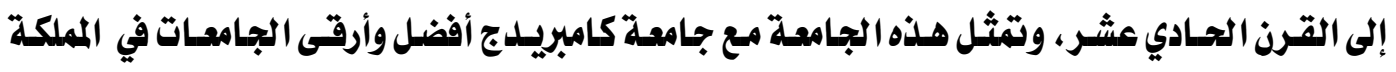

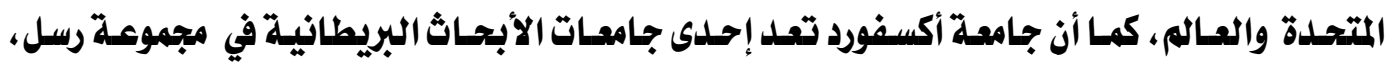
وعضو مجموعة كومبرا وهي شبكة من الجامعات الأوروبية التتقدمة، كمـا أنها عضو في رابطة جامعات الأبحاث الأوروبية. ( الموسوعة الحرة ويكيبليا، 19.r ).

وتتصلدر جامعة أكسفورد تصنيفات الجامعـات البريطانية المحترف بها، وأهها تصنيف صحيفة التايمز البريطانية، حيثاحتلت الجامعة المركز الأول بهذا التصنيف لأعوام Vا.rم، A ا.rم،

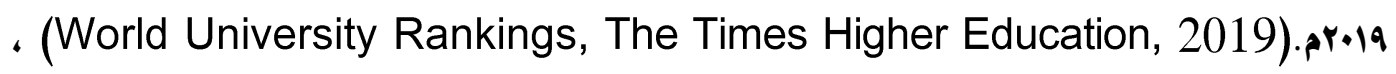

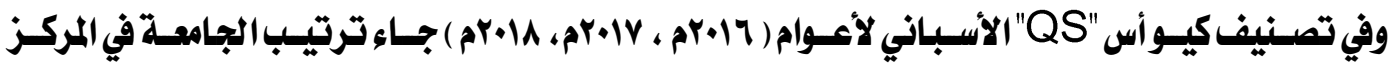

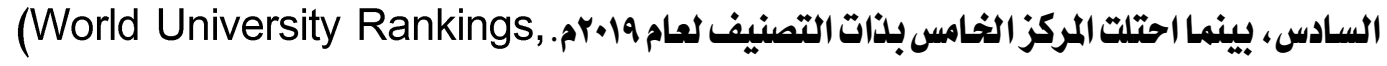

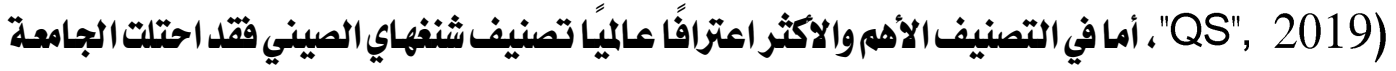

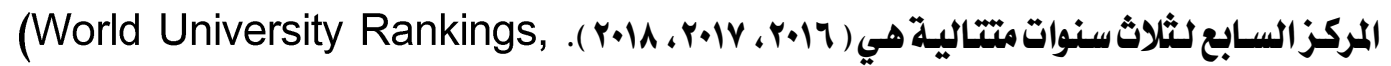
Shanghai Ranking, 2018)

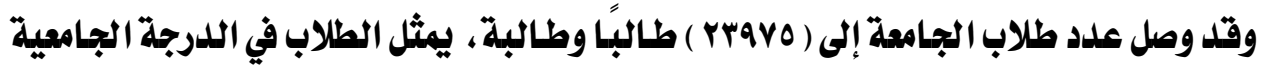

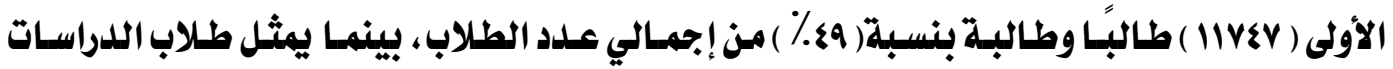

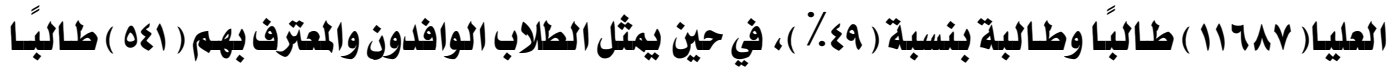
وطالبة بنسبة ( ٪ ) ، وهذا يعني أن طلاب الدراسـات العليـا في مرحلتي الماجستير والدكتوراه يمثلون

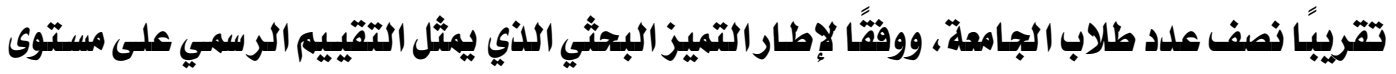

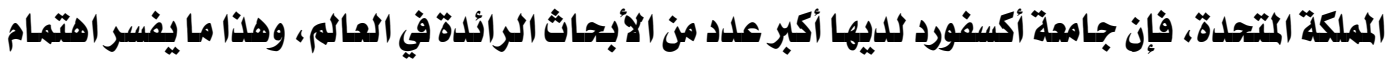


الجامعة المتزايلد بنظام الإثراف العلمي والبحثي على هؤلاء الطاب ورسائلهم ؛ مما دعى الباحث لاختيسار خبرة

تلك الجامعة لتكون ضمن الجامعات موضع المقارنة. (The University of Oxford ,2019). وفي ضوي مكانة جامعة أكسفورد محليًا وعاليًا وكونها رائدة في مجال البحث الالعلمي على مستوى الدراسات العليا، فقد تم اختيارها لعرض نظام الإثراف العلمي بها ؛ من أجل الاستفادة من نقاط قوته في تطوير الإثراف العلمي بـالجامعات المصرية، وبمـا يتوافق وطبيعة المجتمع المصري وثقافته وسياسـاته التعليمية والبحثية، ويمكن استعراض نظام الإثراف على الرسائل والبحوث العلمية بجامعة أكسفورد من خلال محاور البحث المختارة وحلدوده الموضوعية على النحو الآتي: ا- إدارةوتنظظيم الإشراف العلمي:

يقع على عـاتق لجنـة التعليه Education Committee بـوزارة التعلييه في إنجلترا المسؤولية الشـاملة عن التعريـف والتقويم والمراجمة المستمرة للفلسفة التعليمية والبحثيـة والسياسـة والمعايير الجامعية فيمـا يتعلق بـالتعليه والتعلم والبحث العلمي، ويـرأس لجنة التعليه بـالوزارة نائب مستشار التعليم، وتسهم اللجنة في تطوير السياسات التعليمية والبحثية، وتنظر في التعديلات المقترحة للبرامج واللوائح البحثية) (Ministry of Education in England, 2019) وبصفة خاصـة، تتـولى مجـالس الكليـات والأقسـام العلميـة بجامعـة أكسفورد مسؤولية إدارة وتظظيه الدراسات العليا والإشراف العلمي وضع كل طالب بحث - ئعترف بله ويُسجل- ت تحت إشراف عضو هيئة تلدريس من أعضاء الجامعة أو شخص مختص من خـارج الجامعة، مع الحفـاظ على الأداء الإثرافي الفعال، ويجوزللمجلس المسئول لأسباب وجيهة ووافية تفيير الثشرف على أي طالب، أو الترتيب للإثراف المشترك من قبل أكثر من مشـرف عنـل الضـرورة، وعلى المجلس المختص التـأكلد من أن المشرف أو المشرفين المينين مؤهلين بشكل مناسب وفقًا للمعايير المحددة، ويلدركون وينفذون سياسة الجامعة والكلية والأقسسام فيما يتعلق بالإثراف البحثي، كما تهته هده المجالس بتلبية الاحتياجـات التدربيية للمشرفين الجدد والمبتـلئيز من أعضاء هيئة التـلدريس، والتأكلد من إجـراء الترتيبـات البليلة والمناسبة للدعم الطالب وتوجيهه في حالة غياب المشرف أو مرضه أو ذهابه في إجازة تقرغ بحثي، كما يمكن للمجلس المسؤول على مستوى ( القسم/ الكلية/ الجامعة ) تفيير المسؤوليات الإثرافية بنـائً على طلب من الطالب أو المشرف، \$17

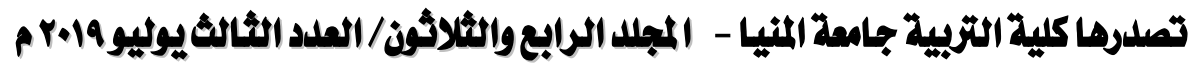
gamel_abdo59@yahoo.com

http://ms.minia.edu.eg/edu/journal.aspx 


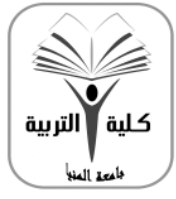

\section{مجلة البعث في التزبية وعلم النفس \\ كلية التربية - جامعة المنيا}

كلية مُشتمدة من الهيئة القومية لضمان جودةالتعليم

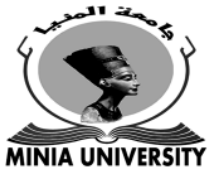

وعلى المشرف أن يتعرف مسؤوليات كل من الطالب والقسم وأعضاء هيئة التدريس ضمن العلاقة الإثرافية

تجساه عملية الإثرافوالباحث. The University of Oxford, Policies and guidance, 2019).

ويقوم المجلس المسئول في إطار إدارةوتنظيم إجراءات الإثراف على الرسائل والبحوث بإخطار

وإعلام الطاب والباحثين الجدد بالموعد اللذي يمكن فيه توقع تعيين المشرفين عليهم ؛ حيث لا يتم تعيين المشرفين إلا بقبـول وتسجيل الطالب بسجلات الدراسـات العليـا في الجامعة، ويجب أنيعطى كل طالب وسيلة اتصـال وتواصل واحلدة محددة وواضـحة مع الثـرف الرئيس، كمـا يجب إبلاغ الطالب بـالاتصال والمساعدة البديلة في حالة عدم توافر أو غياب المشرف الرئيس، وقديكوز ذلك من خلال المرف الثانوي أو عضو إضافي معين من أعضاء هيئة التدريس القادرين على تقليم الثورة والدعم والتوجيه ؛ ولتجنب سوء الفهم وانتطاع التواصل يتم توفير الأسماء وتفاصيل الاتصال والمسؤوليات الخاصة بـالثرفين الرئيسيين وغيرهم من الشرفين الثانويين على الطاب الباحثين، من خلال إتاحتها في جحيع أدلة وبرامج الدراسات العليا الخاصة بالطلاب.)(Oxford University, Humanities Division, 2018:2) وتختلف أنماط الإثراف العلمي من كلية إلى أخرى داخل جامعة أكسفورد بحسب طبيعة التخصص والموضوعات البحثية، ففي بعض التخصصات يوجد عادة مشرف وحيد، وقتد يكون للباحث في تخصصسات أخرى اثنان من الشرفين المشتركين، وفي حالة تعيين أكثر من مشرف عـادة مـا يتم تعيين أحلد المشرفين

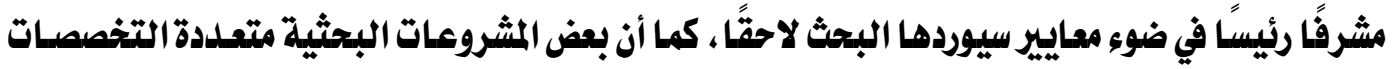

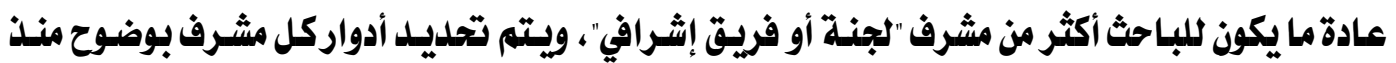
البلاية، وتقدم الترتيبات والتوجيهات بشكل واضح للطالب، وفي جحييع الحسالاتيتم التأكلد من أن كل طالب للديه الحق في الوصول إلى مشرفواحلد أو أكثر من الشرفين وبسهولة للحصول على اللدعم، ذلكك إضافة إلى الشرف الرئيس ومصادر اللدعم الأخرى مثل : مستثار القسم، أو رئيس مجموعة البحث، أو ملير اللدراسات العليا أو رئيس مجلس الكلية ( عميلـ الكلية ) عندل الحاجـة الضرورية، كمـا يجب على الإدارات والكليـات التأكلد من أن التوقعـات الإشرافية فيما يتعلق بـلدور المشرف واللقـاءات والأدواروالمسئوليات الإثرافية منتظمة مع الطلاب، ويتم توضيحها وتحليدها بشكل دقيق ويفهها جميع المشرفين والطلاب. \& IV

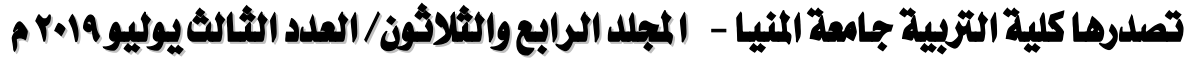
gamel_abdo59@yahoo.com

http://ms.minia.edu.eg/edu/journal.aspx 


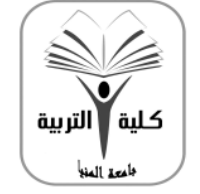

\author{
مجلة البعث في التزبية وعلم النفس \\ كالية التربية - جامعة المنيا
}

كالية مُعتملة من الهيئة القومية لشمان جودة التعليم

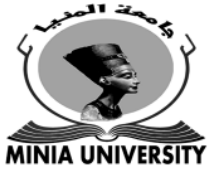

(Oxford University, Social Sciences Division, 2018:3)

كما توصي كليات قطاع العلوم الطبية في الجامعة بشدة لتعيين مشرف مشارك لجميع الطلاب

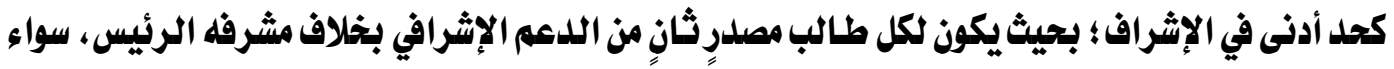
أكان هذا المصلدرمشرفًا إضافيًا، أو مستشاراً للقسم أو غيرهما. Oxford University, Medical Sciences Board, 2014:2) وتتخذ كليات الجامعة ومجالسها المختصة عند تعيين الإشراف العلمي كافة الإجراءات الإدارية

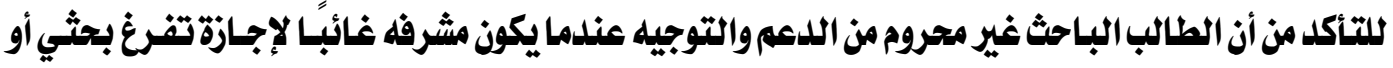

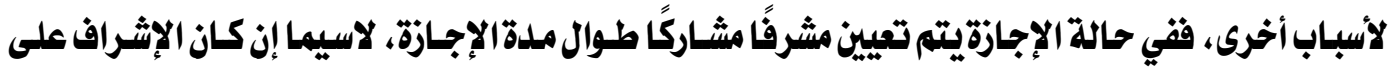

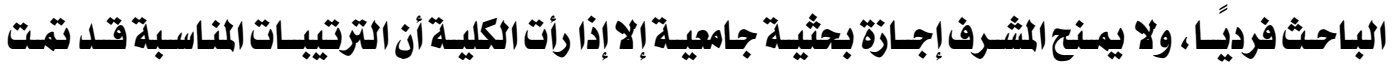
للإثراف على طلابها. (Oxford University, Humanities Division, 2018:2) وتتولى المجالس المختصة متابعة الإثراف والتأكلد من أنه بالتعاون مي الطالب يتم تحليد

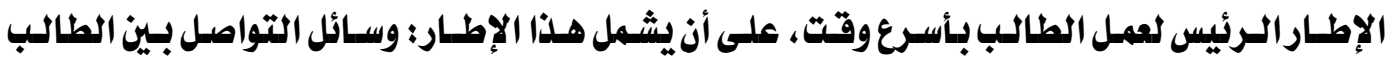
والشرف، وكيفية ترتيب الاجتماعات بشكل منتظم ورصد التقدم، وتنسيق المشورة والتوجيه في حالة

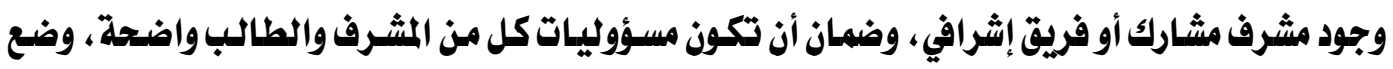

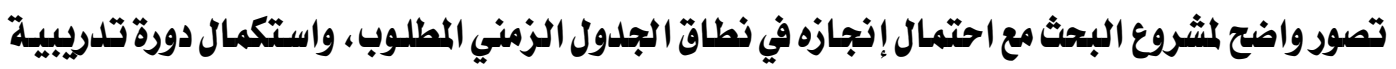

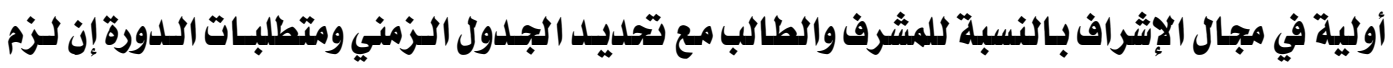

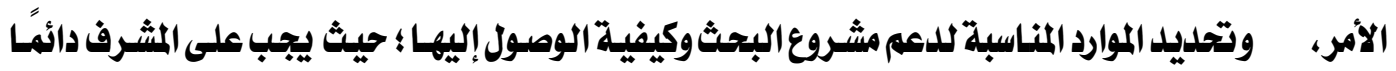
التأكل من توافر الدعم المالي الكافي طوال فترة الدراسة والبحث، وضع ضمانات لتدريب الطالب على الصحة

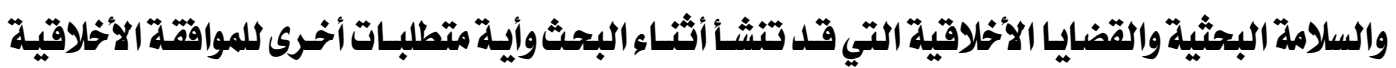
على إجراء البحث.) (Oxford University, Student Systems, 2019) وتتم متابعة وتقويم العملية الإثرافية على طلاب الدراسات العليا بجامعة أكسفورد من خلال ما

"Graduate Supervision Reporting" يسمى بتقارير الإشراف على الدراسـات العليا 


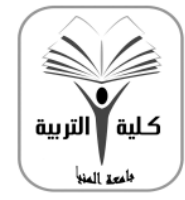

\section{مجالة البجث في التزبية ومام النفس \\ كالية التربية - جامعة المثيا}

كالية مُتملةةمن الميية القومية لضمان جودة التمليم

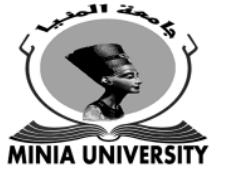

(GSR)

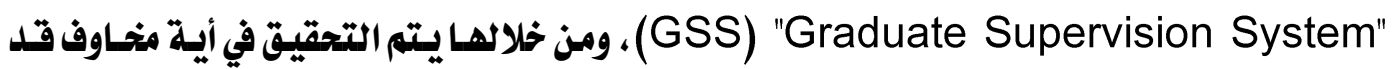
تؤثر على تتحدم بحث الطالب، ولابـل للمجلس المسئول عن تعيين المشرفين معرفة مـا إذا كانت تقـارير المتابعة قد اكتملت من قبل الطالب والمشرف، وإعداد تقارير مستمرة حول أداء الطالب في نهايـة كل فترة حتى ثهاية ملة البحث وتقديم الأطروحة للمناقشة والفحص، ومن المههم أن يقوم ملير الدراسـات العليـا المسؤولوذ بمراقبة إعداد هذه التقارير، ومتابعة التقارير غير الموثقة ومراجعتها، حيث يتم استخدام GSS من قبل طلاب الدراسات العليا والمشرفين ومستشاري الكلية ومديري الدورة التدريبية لتطوير أداء الششرفينDelopment Graduate Supervision) Develd) ومراجمة التقلدم اللدراسي والبحثي للطلاب.)(Oxford University, GSS, 2019) كما تقوم الجامعة وكلياتها في سبيل متابعة العملية الإثرافية بتعييز مستشار جامعي للإثراف، وتتلقى تثارير إشراف دورية ومستمرة حول الأداء الإثـرافي، وهنـاك إجـراءات منتظمة وواضـة لرقابـة ومتابعة الإثراف على طلاب الدراسات العليا منها مناقشة التقلم الاكاديمي والبحثي وتقـارير الإثراف مع المشرفين والطاب، وإذا رصد المجلس المختص بـاكلية أية مخاوف قد تؤثر على التقدم البحثي للطالب تخص الإثراف العلمي لميتم الاعتراف بها والإثارة إليها في تقارير الإشراف، فإنه يجوز إحالة هذه الأمر إلى ملير (وكيل ) الدراسـات العليـا في الكلية المعنية Oxford University, Humanities) .Division, 2018:2-3)

ويجوز للمجلس المختص ( القسيم/ الكلية/ الجامعة ) بتعييز المثرفيز اتخـاذ الإجراءات اللازمة (Oxford University, لتفيير الإثـراف على الطلاب عنـل الضرورة، وذلك في حسالات معينة، هي :Social Sciences Division, 2018:3) أ- عند شعور الطالب بـأز هناك أسبابًا وجيهة للتفكير في تفيير المشرف، وفي هذه الحالة يجب أولاً أن يناقش الطالب مشرفه في تلك الأسباب، وإذا كان هذا يبلدو صعباً فقي وجود رئيس القسم أو مستشار الكلية، أو إذا كان الطالب يفضل فمع ملير الدراسات العليها أو رئيس مجلس الكلية ( العميد أو نوابه ) 
أو مع المستشار الجامعي للإشراف العلمي.

ب- حال تفيير توجهات بحث الطالب، بحيث لا يكوز مشرفه الحالي هو الشخص الأنسب لتقليم التوجيه واللعم بشأن الموضوع المعدل، فيجب على الإدارات وا لمجالس المختصة بالتشاور مع المشرف المعني والطالب النظر فيما إذا كان يجب تعيين مشرفًا إضافيًا أو بلديلًا، إلا أن مثل هذه الحالة غير متادة، ويتطلب ذلك دائمًا إنًا مسبقًا من القسه والكلية لتفيير توجهات البحثث وعنوانه أو موضوعه. ج- عند وجود مخاوف للى الطالب بشأن جودة الإشراف، فمليه أن يسى لحل المشكلة - قدر الإمكان- من خلال المناقثة مع المشرف، أو ملير الدراسات العليا، أو رئيس مجلس الكلية، أو مستشار الكلية للإثراف، ويجب أن يكوز الطالب على علم بإجراءات الشكوى الرسمية بـالجامعة في حالة الشكاوى، وتلك الإجراءات موضحة بلدليل الطالب واللوائح ذات الصلة بـالجامعة. د- إذا تقرر أن تفيير المشرف أمر مرغوب فيه من قبل طرفي الإشراف ( المشرف والباحث )، وإذا لم يكن هناك مشرف بلديل متخصص متاح في الجامعة، فيمكن تعيين مشرف متخصص من خارج جامعة أكسفورد أو عضو خبير في فريق الإثراف كمشرف مشارك في ضوي معايير تمييز المشرف الخارجي كما سيوردها البحث لاحقًا، وهكذا حالات السفر وإجازات التفرغ البحثي، والظروف المرضية، وغيرها. وتضع الجامعة وكلياتها سياسات لتحليدل العبء أو الحمل الإثرافي لأعضاء هيئة التدريس وفقًا لطبيعة التخصصات المختلفة، ففي كليات قطاع العلوم الطبية والطبيعية بجامعة أكسفورد تنص سياسة وقواعد ممارسة الإثراف على طلاب اللدراسات على أنه لا يجوز لعضو هيئة التـدريس الإثراف على أكثر من ( 7 ) ستة طلاب في وقت واحل، ويتم احتساب الإشراف المشترك للطالب على النصف، بفض النظر عن العلدد الإجمالي للمشرفين على الطالب. Oxford University, Medical Sciences

Board, 2014:2)

أما في كليات قطاع العلوم الإنسانية بجامعة أكسفورد فتنص سياسة العبي الإثرافي على أنه لا يجب على عضو هيئة التدريس الذي لديه عبء أو حمل إداري عادي ( المسئوليات الإدارية المعتـادة لأستاذ الجامعة ) وعبي طبيعي من التـلدريس للطلاب الجـامعييز أو اللدراسـات العليـا ( جـلول محسد السـاعات التلدريسية ) أن يشرف على أكثر من ( 7 ) ستة طلاب بـاحثين، ويمكن لأعضاء هيئة التـدريس الـلين للديهم $\varepsilon r$.

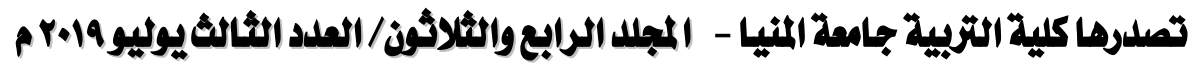
gamel_abdo59@yahoo.com

http://ms.minia.edu.eg/edu/journal.aspx 


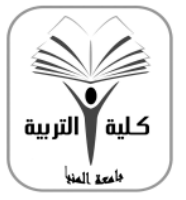

\section{مجالة البجث في التزبية ومام النفس \\ كاية التزبية - جامعة المنيا}

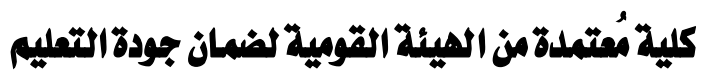

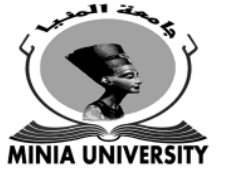

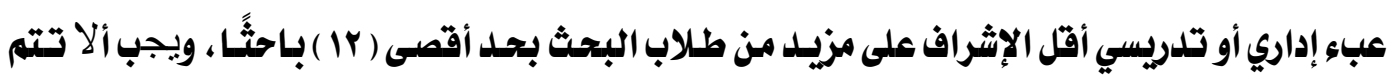

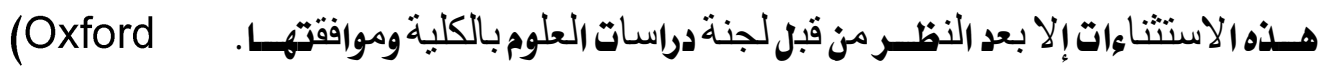
University, Humanities Division, 2018:4)

وفي كليات قطماع العلوم الاجتماعية توجلد آليـات لضمان علدم تعرض جـودة الإثراف للتـلني والضعف بسبب الأعباء الإدارية والتدريسية الزائلة واتساع نطاق المسئوليات الأخرى للمشرفين وخاصة في حالات الإثراف الفردي، ومن ثم فإن القاعدة الأساسية للحمل الإثرافي بتلك تثص على الإثراف على ( ) : ؛ ) طلاب فقط للمشرف ؛ وذلك حتى يكوز قادراً على توفير المستوى النموذجي من التوجيه واللدم لكل طلابه ، كما يجب على إدارة الكلية اتخاذ الترتيبات المناسبة لتفطية غياب المثرف في إجـازة تثرغ بحثي أو لأسباب أخرى، ولا ينبفي التعيين كمشرف لعضو هيئة تدريس على وشك اللذهاب في إجـازة بحثية؛ تجنبًا لحرمان الطلابمن السعم والتوجيه. Oxford University, Social Sciences)

Division, 2018:3)

ومما سبق، يتضح أن مهمة إدارةوتنظيم الإثراف العلمي على طلاب اللدراسـات العليـا بجامعة أكسفورد تختص بها مجالس رسمية تضع قواعد وإجراءات وسياسات للممارسات الإثرافية، وتحلد العبي الإثرافي لكل عضو هيئة تدريس لا يتعداه إلا بموافقة رسمية من مجلس الكلية، كما حددت تلك المجالس حالات تفيير الإشراف وإجراءاتها، ومصادر الدعم والتوجيه في حالة غياب المشرف الرئيس لأيسة أسباب، كما تضع كليات الجامعة بقطاعاتها الإختلفة آليـات وأسـاليب لمتابعة ورقابـة جـودة العملية الإثرافية؛ مما ساعد في حصول جميع الطلاب على التوجيه واللدمم المناسب لإنجاز رسائلهم وأطروحساتهم في الوقت المناسب وعلى أكمل وجه.

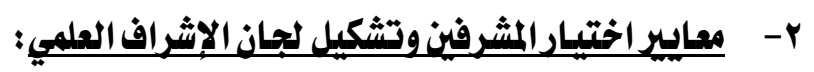
تتنوع وتتعدد معايير اختياروتعيين الشرفين، وتشكيل لجان الإشراف العلمي بجامعة أكسفورد بتنوع قطاعات وتخصصات كليات الجامعة، إلا أن هناك قواسم مشتركة بينها، فقي كليـات قطـاع العلوم الاجتماعية والإنسانية تتمثل معايير اختيـار المشرفيز وتشكيل لجسان الإثراف في الآتي: Oxford (Oxford University, Social ، University, Humanities Division, 2018:3-4) $\varepsilon r$

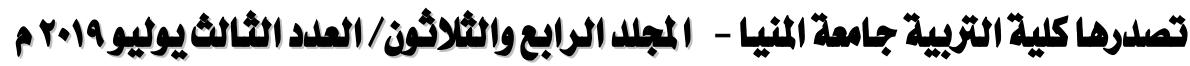
gamel_abdo59@yahoo.com

http://ms.minia.edu.eg/edu/journal.aspx 
: Sciences Division, 2018:3)

يجب أن يكوز المشرف الرئيس عادة عضواً من أعضاء هيئة التدريس بـالجامعة، أو أحلد زملاء الجامعة أو الكلية، ممن يتمتعون بمكانة وخبرة مناسبتين، ويتسم بـالمصداقية والجلية في أداء

مهامه الإثرافية.

أن يكون للى المشرف الخبرة الكافية لتقديم التوجيه المناسب للطالب حول الإجراءات البحثية الثلازمة،وعلى وجه الخصوص الخبرة بالتوقعات الاكاديمية المرتبطة باللدرجات العلمية ( الماجستير والدكتوراه ) في جامعة أكسفورد وفي مجال التخصص. ج- أن يكوز المشرف قادراً من حيث المكانة الاكاديمية والخبرة على القيام بـالمهام الإثرافية والبحثية المسنلة إليه والعمل على دمجها في السياسات والمهام الوطنية واللدولية في موضوعات الأبحاث

$$
\text { التي يشرف عليها. }
$$

د- أن يكوز المشرف للديه ما يكفي من الوقت لضمان متابعة أبحاث الطالب حتى النهاية الناجحة. فمادة لا يته تعيين المشرف إذا كان من المعروف في وقت التعيين أنه لن يكون في وظيفته أو لليه إجازة تفرغ بجثي أو غير ذلك. ه- أن يكوز للدى المشرف معرفة كافية بـالتوقعات المؤسسية والوطنية والدولية المتعلقة بالبيئات

$$
\text { البحثية والإشراف على البحوث والتدريب. }
$$

و- في حالة الحاجة إلى إثراف علمي متخصص، ولا يتوفر بالجامعة يتم تعييز عضواً من أعضاء هيئة التدريس بـالأقسام أو الكليات المناظرة ذات الصلة، أو شخص يحمل منحة خارجية أو ما يعادلها في ذات القسم والتخصص، وفي هذه الحالة يمكن تعيين عضو خبير في فريق البحث كمشرف متخصص في الموضوع، أو تقيين مشرف من خارج جامعة أكسفورد كمشرف مشارك، وقد لا يتم قبول المرشح ( الطالب ) بالأساس إذا لم يكن هناك إثراف متخصص ومناسب في الجامعة أو كلياتها وأقسامها

ز- يشارك مشرف واحد على الأقل في الإشراف على بحث الطالب ما لم ثكن هناك ضرورة للتعدد وبجسب طبيعة التخصص والموضوعات البحثية. \&r

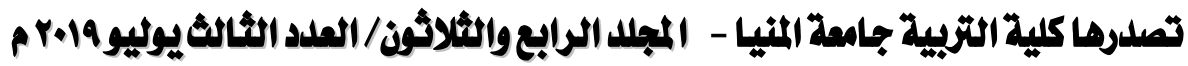
gamel_abdo59@yahoo.com

http://ms.minia.edu.eg/edu/journal.aspx 
وبـاستقراء المعـايير السـابقة، يُلاحظ تركيزهـا على معسيير محسدةة، أهمهـا : عضـوية المشـرف بالجامعة - وخاصة المشرف الرئيس- عند تعلد الإثراف ؛ حتى يستطيع مباشرة مهام الإثراف على

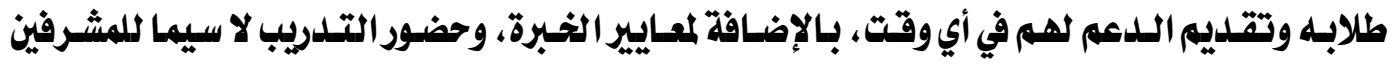
الجدد، الإتاحة والتفرغوضمان الوقت الكافي لممارسة مهام الإشراف بشكل جيد، مع وضع معايير لحالات الإشراف المتخصص من خلال توفير مشرف خارجي أو علدم قبول ترشيح طالب البحث إذا لم يوجد الإشراف المتخصص بـالجامعة والكليات والأقسام المناظرة. أما في كليات قطاع العلوم الطبية، فلكي يكوز عضو هيئة التدريس مؤهلاً للتعيين كمشرف رئيس (Oxford University, Medical أو المشرف الوحيد على طالب، يجب أن يستوفي المعايير التالية : Sciences Board, 2014:1) خبرة سابقة في الإثراف على طالب أتم مشروع بحثه أو أطروحته بنجاح إما في جامعة أكسفورد أو في جامعة أخرى خارج أكسفورد. قدرة المشرف في الحصول على دخل ( منحة ) بحثية لتفطية تكاليف المشروع البحثي بـالتعاون مع

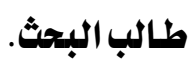

للديه سجل مشرف من المؤلفات والمطبوعات الحليثة في مجال تخصصه خلال الخمس سنوات

$$
\text { السابقة للعمل كمشرف رئيس على الباحثين. }
$$

إبرام عقد عمل مع الجامعة لإذجاز دراسات الطالب، أو الحصول على موافقة مجلس القسم للعمل

$$
\text { كمثرف. }
$$

وإذا لم يستوف المشرف الأساسي أو الرئيس المعايير السـابقة ليكوز المشرف الـرئيس أو الوحيله، يجب تميين مشرف مشارك من الاكاديميين الأقدم في جامعة أكسفورد، ويجب على المشرفين الرئيسيين لأول مرة ألا يـأخدوا طالبًا ثانويًا حتى يتم الطالب الأول أطروحته أو مشروعه البحثي بنجاح. وبملاحظة المعايير السـابقة يتضح تركيزهـا على تعييز إشـرافًا فرديًا على الباحث من خلال مشرف وحيد أو رئيس يمتلك مع طالبه قدرة الحصول على موارد وتسهيلات مالية لتفطية نفقـات المشروع البحثي، لليـه خـبرة سـابقة في الإشراف داخل أكسفورد أو خارجها، وله إنتـاج علمي من مؤلفـات ومطبوعـات \& r

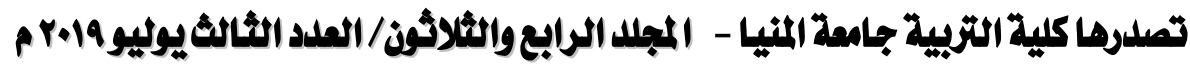
gamel_abdo59@yahoo.com

http://ms.minia.edu.eg/edu/journal.aspx 


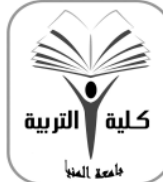

$$
\text { مجلة البعث في التزبية ومام النفس }
$$

كلية مُنتملة من الميئة القومية لضمان جودة التمليم

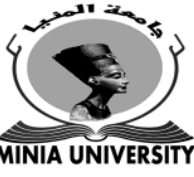

وأبحاث حليثة في مجال التخصص، وحاصل على عقل عمل أو مواققة مجلس القسم المختص للإثراف البحثي.

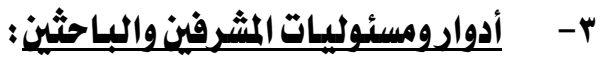

يوجد بجا معة أكسفورد وثائق وسياسـات للإثراف العلمي على الطلاب في التخصصسات المختلفة العلوم الاجتماعية والإنسانية والطبية، وتحلد هذه الوثائق قواعد وممارسسات الإثراف العلمي الفمال وإجراءاته ، وأدوارومسئوليات كل من الششرف والطالب بشكل واضح ومحدد خلال مراحل البحث المختلفة من البداية حتى النهاية وتقليم الأطروحة للمناقشة والفحص، ويمكن توضيح ذلك على النحو الآتي: أ- أدوارومسئوليـات المشرف:

تضـع وثائق وسياسـات الإثـراف العلمي بكليـات قطـاع العلدوم الاجتماعيـة والطبيـة بجامعـة أكسفورد قائمة لمراجعة أدوارومسئوليات الإثـراف العلمي تتضمن مجالات وأدوارومسؤوليات المشرفين، حيث هناك مجموعة من الأدواروالمسئوليات العامة للمشرف، وأخرى خاصة بمراحل البحث المختلفة من (Oxford University, الناحية العلمية والإدارية والأخلاقية، وتتمثل هذه الأدواروالمسئوليات في (Oxford University, Medical .Social Sciences Division, 2018:5-6) :Sciences Board, 2014:2-5) 1. توفير القيادة الاكاديمية للطالب وتوضيح التوقعات الإثرافية المتبادلة، حيث يقوم الثرف الشارك بتنسيق المشورة والتوجيه وبين زملائه، وضمان أن تكون مسؤوليات كل منهما واضحة

$$
\text { للزهملاء الاكاديمييين وللطالب الباحث. }
$$

r. تقليم الشورة للطلاب حول جحييع جوانب البحث: تحليد موضوع البحث، وكتابته خلال الفترة المحددة، والمعايير المطلوبة في كل عنصر، والتخطيط، والأدب والمصادر... إلخ، وتقديم المشورة في مرحلة مبكرة بشأن تصميه البحوث ومنهجية وأدوات جمع البيانات والمعلومات. r. إجراء مراجعة دورية للمهارات وتحليل الاحتياجات التلدريبية مع الطالب، وتشجيع الباحث لحضور دورات تدريبية في مجال البحث والتدريب المهني.

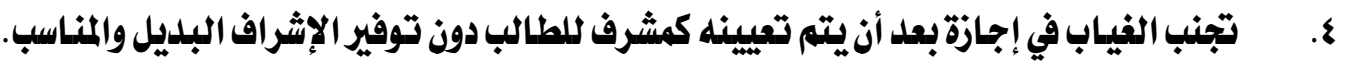
0 0. الاتفاق مع الطالب على لقاءات إشرافية وتكرارها ومدتها، والسرعة المتوقعة للتعليق على أعمال

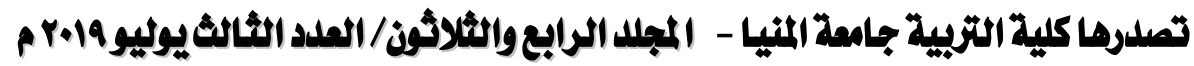
gamel_abdo59@yahoo.com

http://ms.minia.edu.eg/edu/journal.aspx 


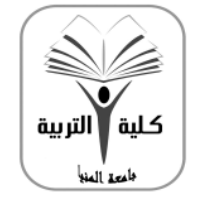

\author{
مجلة البعث في التزبية وعلم النفس \\ كلية التربية - جامعة المنيا
}

كلية مُتملدة من الهيئة القوميلة لشمان جودة التمليم

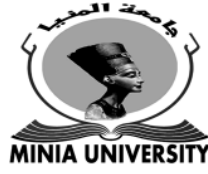

الطالب الكتتوبة، وإعادة العمل المقدم بنقد بناء في غضون فترة زمنية معقولة.

7. الاحتفاظ بسجلات مكتوبة للاجتماعات لضمان أن يكون كل من الطالب والمشرف واضحًا بشأن

الإجراءات الواجب اتخاذها والمساعدة في رصل التقدم البحثي.

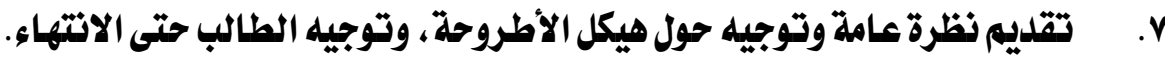

A. توجيه الطالب إلى القضايا الأخلاقية والقانونية المرتبطة بالبحث وتجميع البيانات، وإجراءات

طلب الموافقة الأخلاقية من خلال لجنة الأخلاقيات البحثية.

التأكل من معرفة الطالب واتخاذه الإجراءات المناسبة فيعا يتعلق بأية قضايا تتعلق بالصحة

والسلامة المرتبطة بالبحث، بما في ذلك العمل الميلاني، والقضايا المتعلقة بحقوق الملكية

الفكرية، وحقوق الطبع والنشر لطرف ثالث للنسخة الطبوعة والاطروحة الرقبية.

1. توجيه الطالب إلى تجنب الانتحال العلمي والوعي بالتوجيه الجامعي بشأن الاتتحال.

11. مراجعة تعليقات الطلاب وتقليم تقارير أسبوعية عن عمل الطالب باستخلام نظام الإثراف على

اللدراسات العليا (GSS)، بما في ذذلك مراجعة وتحديث متطلبات التدريب، مناقشة محتويات

التقرير البحثي مع الطالب.

r rا. تزويد الطالب بمعلومات منتظمة حول تقدمه في البحث، وعندما تظهر الشكلات يقدم التوجيه

والمساعلة والإجراءات التصحيحية اللازمة.

rا. التأكلد من أن الطالب على دراية بمرافق وأنشطة البحث في قسم أو هيئة تلدريس التابع لها،

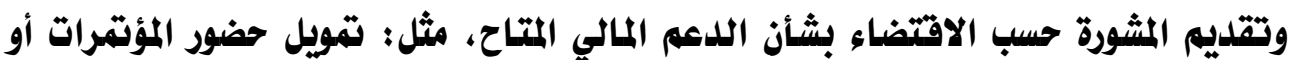

الرحلات الميدانية أو غيرها.

1ء. تقديم معلومات إلى إدارة الكلية والدراسات العليا ذات صلة بحضور الطلاب لاجتماعات الإثراف،

والسيمنارات، والمناقشات والمؤتترات والندوات العلمية المتخصصة، وحول مستوى التقدم

الاكاديمي والأداء والبحثي للطالب.

10. مساعدة الطالب في التحضير لعملية الفحص والمناقثة والتأكلد من معرفة الطالب لجميع إجراءات

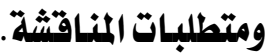

\title{
s ro
}

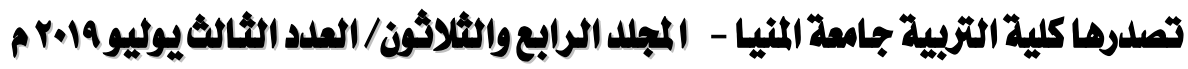

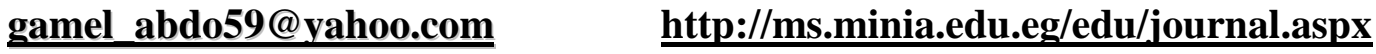




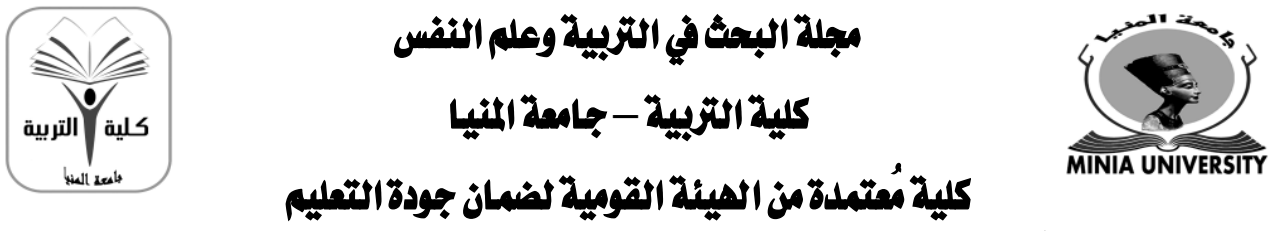

17 . تقديم الشورة للطالب بشأن توقيت تقليم الأطروحة والتشاور مع الطالب لتقديم توصيات وآراء

اختيار الفاحصين أو المناقشين.

IV. تشجيع الطالب للحصول على المعرفة والمعلومات حول فرص العمل وتتبيهله إلى الخدمات الأخرى

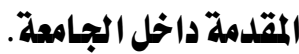

11. السعي لإتاحة فرص للطلاب للمشاركة في الجياة الفكرية والمهنية ومناقشة أعمالهم مع أقرانهم في المجتمع الأوسع وفي الجامعة وعلى المستوى الوطني والدولي، وتوفير فرص تنمية المهارات وصقل الخبرات.

أما في كليات العلوم الإنسانية بجامعة أكسفورد تقدم وثثيقة ممارسـات الإثراف العلمي ملخصـا

(Oxford University, بسأدوارومسئوليات المشرفيز على طلاب الدراسـات العليـا، تتمثل في :Humanities Division, 2018:8) 1. الحصول على المعرفة المتخصصة والتدريب اللازمة للإثراف على أبحاث الطالب. r. الحصول على خبرة سابقة في الإشراف على طلاب البحث في جامعة أكسفورد. r. ضمان أن للديه الوقت الكافي للإثراف على الطالب وتوجيهل ومساعدته.

ع. قببول الإشراف على الطالب فقط، إذا كان قادراً على ضمان استمرارية الإشراف حتى النهاية. ه. تقديم المشورة والتوجيه ودعم الطالب في جميع جوانب البحث، وتوفير قيادة فكرية واضحة، وتقديم إرشادات دقيقة حول التوقعات الاكاديمية. 1 I. إعداد تقارير الإشراف للمتابعة المستمرة لمستوى تقلدم الطالب، وتقديم تقرير مفصل عن تقلم الطالب في نهاية كل فصل، بـاستخدام نظام الإثراف عبر الإنترنت ( GSS ). V. تحليل الاحتياجات التلديبية لتنمية مهارات طلاب البحث، ومساعدتهم في الحصول على التدريبات المناسبة. A. مساعدة الطالب وتشجيعه على المشاركة في المجتمع الاكاديمي الأوسع بالجامعة والكلية أو المجتمع العلمي والاككاد يمي بـالجامعات الأخرى بإنجلترا وخارجها. 9 ه. مساعدة الطلاب في الحصول على تقويل من هيئات التهويل البحثي المختلفة، وتعريفه بـالشروط \& 4

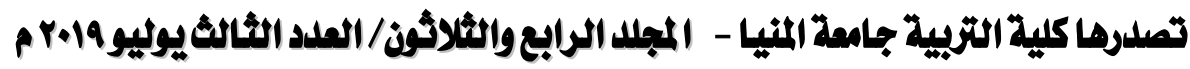
gamel_abdo59@yahoo.com http://ms.minia.edu.eg/edu/journal.aspx 
والأحكام المرفقة بـالمنحة ؛ من أجل ضمان استيفاء الطلاب لهذه المتطلبات والأحكام.

كما توجل بجميع كليات الجامعة وتخصصاتها المختلفة مسئوليات وأدوار للمشرف خلال التجريب الييداني لبحث طلابـه وخاصة في قطاع العلوم الطبية والإنسـانية، حيث إن للجامعة والمشرفيز واجبًا قانونيًا للعناية بطاب البحث الذين يقوموذ بـالعمل الميلداني من حيث الصحة والسلامة للطلاب ولعينة البحث، وقد تم وضع سياسات وإجراءات لتحليد كيفية تنفيذواجب الرعاية الصحية والأمن والسلامة، وتتطلب هذه الإجراءات تقييم المخاطر ووضع تدابير وترتيبات مناسبة لتخفيفها، حيث يلعب المشرفون دوراً رئيسياً في هذه العملية من خلال : العلم بسياسـات السلامة الجامعية وإجراءات الكلية ذات الصلة، النظر في آثار الصحة والسلامة لأي مقترح بحثي، والتأكلد من تلقي الطلاب لتـدرببات مناسب في هذا الشأن، التأكلد من أن تقييمات المخاطر قد تم إجراؤها وأن أحكام السلامة المتعلقة بـالعمل موجـودةوتقت مناقشتها وتطبيقها، التأكل من وجود الترتيبـات المناسبة للاتصـال المنتظم لتقلديم اللدعم والتوجيه،

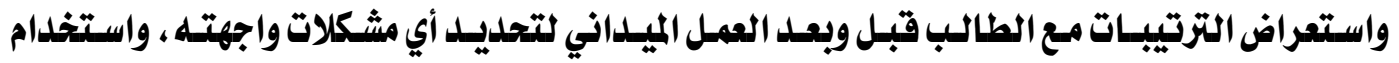
المشرفين لخبراتهم ومعرفتهم الخاصة لتوجيه وتقديم المشورةوالتقيييه أثنـاء التجريب. Oxford) (Oxford University, ،University, Medical Sciences Board, 2014:6) .Humanities Division, 2018:11)

\section{أدوارومسئوليات البياحث:}

تحلد قواعد وسياسات الإثراف العلمي بجامعة أكسفورد أدوارًا ومسئوليات للطالب خلال العملية الإثرافية وعلى مدار مراحل البحث المختلفة ينبفي القيام بها على أكمل وجه ؛ لإنجاز عمل بجثي متميز، حيث تتوافر بـالجامعة وكلياتها قوائم لمراجعة أدوارومسئوليات الطالب في عملية الإثراف خلال مراحل البحث المختلفة، وتتمثل تلك الأدواروالمسئوليات في الآتي Oxford University, Social :Sciences Division, 2018:9-11) 1- التزام الباحث بـالعمل كمضو مسؤول في المجتمع الاكاديمي والبحثي للجامعة. r- تحليل مجال البحث، واستكمال مراجعة الأدبيات، ومعرفة المعلومات الأساسية اللازمة لإنجاز 


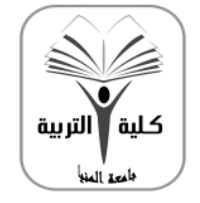

$$
\text { مجلة البعث في التربية وعلم النفس التربية - جامعة المنيا }
$$

كلية مُتمدة من الهيئة القومية لضمان جودة التعليم

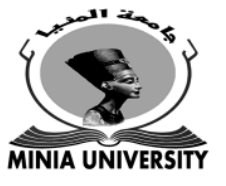

$$
\text { الشروع البحثي على الوجه المنشود. }
$$

ץ- مسؤولية مراجعة مهاراته واحتياجاته التدريبية على أساس منتظم بلدمم من الشرفين، وحضور

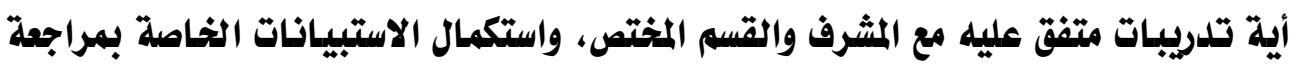

$$
\text { المهارات وتحليل الاحتياجات التلدرببية. }
$$

؟- المناقشة والتوافق مع الشرف حول أنسب نهوذج للإثراف ونوع التوجيه المفيد بالنسبة له.

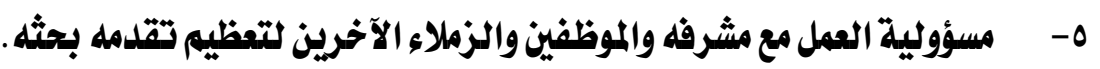

1- التقيد بمتطلبات الجامعة فيما يتعلق بالسرقة الأدبية، والمبادئ التوجيهية القانونية

والأخلاقية المتعلقة بسلامة الأبحاثونزاهتها.

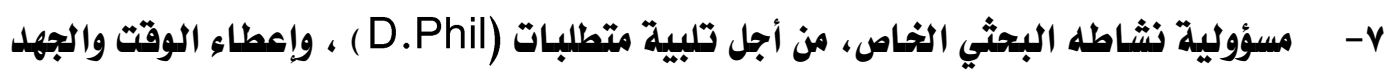

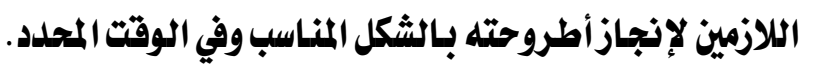

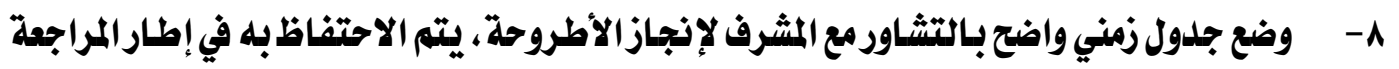
المنتظمة، والحفاظ على السجلات ذات الصلة بجميع جوانب البحث.

9- الترتيب للاجتماعات مع المشرف وتنظيهها، وا لحفاظ على اتصال مستمر ومنتظم مع مشرفه.

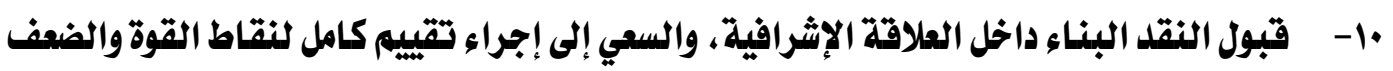

$$
\text { في أدائه البحثي. }
$$

11- الاحتفاظ بسجل مكتوب للمناقشات مع المشرف، وإعطاء الأهمية المناسبة لائة توجيهات مقترحة

$$
\text { ولإجراءات التصحيحية. }
$$

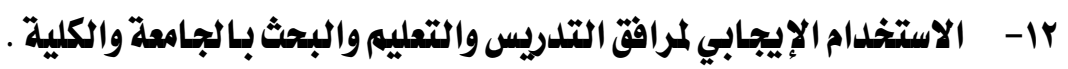

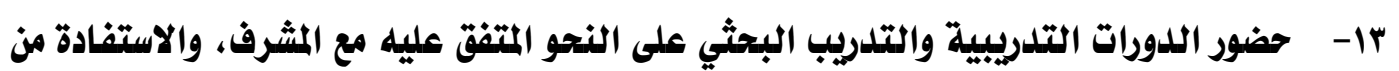

$$
\text { فرص التطوير الشخصي والمهني. }
$$

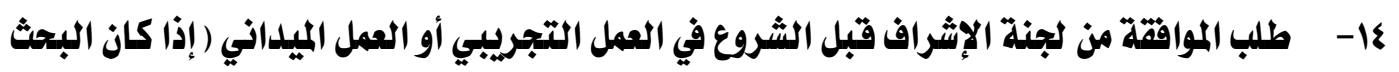

يتضمن جانبًا ميدانيًا )، وبعد مراجعة المرف لالإدوات والمواققة على تحكيهها. 10- كتابة وإعداد التقرير النهائي للبحث بشكل واضح ومفصل وتقديهل للمشرف في موعد مناسب

\section{$\varepsilon r \wedge$}

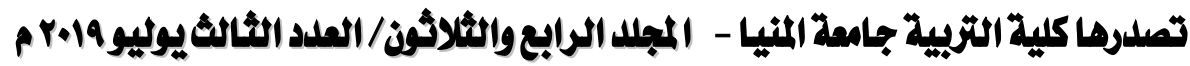
gamel_abdo59@yahoo.com

http://ms.minia.edu.eg/edu/journal.aspx 


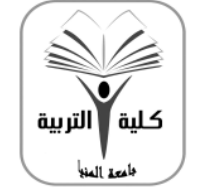

$$
\text { مجلة البعث في التربية وعلم النفس التربية - جامعة المنيا }
$$

كلية مُعتمدة من الهيئة القومية لشمان جودةالتعليم

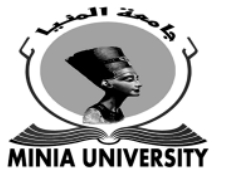

للمراجعة والتعليق، وإجراء التعديلات تثهيلًا لعملية الفحص والمناقشة.

19- تقرير متى يرغب في تقديم الأطروحة للفحص، بعد أن يتيح للمشرف الوقت الكافي للتعليق على المسودة النهائية وبعد أخذ رأي المرف.

مما سبق، يتضح حرص جامعة أكسفورد وكلياتها المختلفة على وضع قوائم محددة وواضحة لأدوار

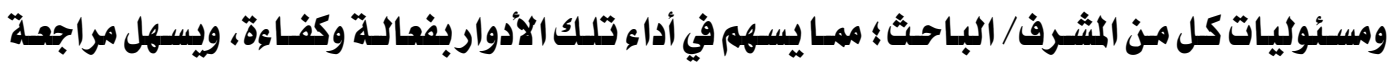
الكليات والأقسام لسير عملية الإثراف، وتعرف الطرف المقصر، واتخـاذ الإجراءات اللازممة حيسال هلدا

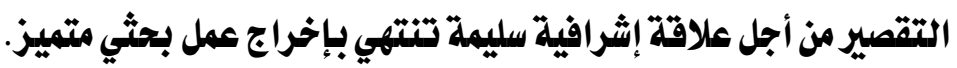
؟- ضوابط العلاقة الاشرافية بين الشرفوالطالب البياهث:

تهتم جامعة أكسفورد وكلياتها بوضع ضـوابطوأسس حاكمة للعلاقة الإثـرفية بـين الثـرف والباحث خلال مراحل البحث المختلفة؛ حتى تستقيم تلك العلاقة وتنتج عملاً عليًًا متميزًا، حيث تم وضع قوائم محددة بـالأدواروالتوقعات المتبادلة بين المشرف والطالب، والتأكلد من علدم حرمان الطالب من

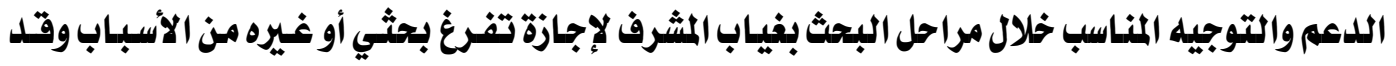

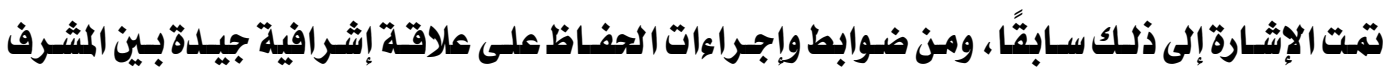

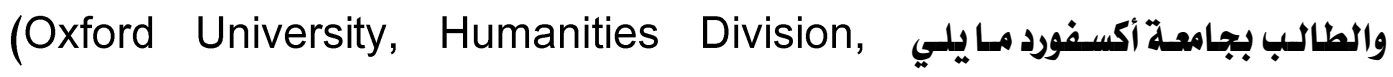

أ- مراعاة رغبة الباحث في اختيار مشرفه، وكذلك ترك مساحة من الحرية للششرف في اختيار

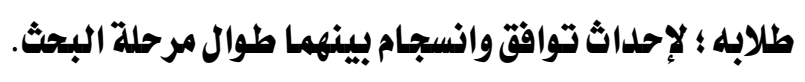

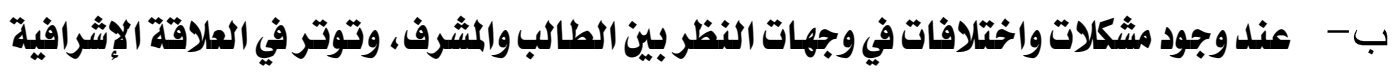

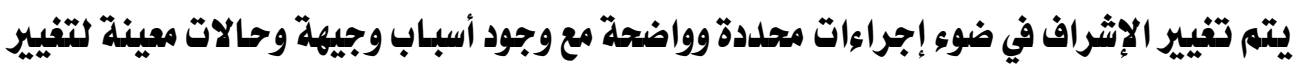

$$
\text { الإشراف، وقد تقت الإثارة إلى ذلك سابقًا. }
$$

ولإرساء دعائم علاقة إثرافية قوية بين المشرف والباحث بكليـات قطاع العلوم الاجتماعية

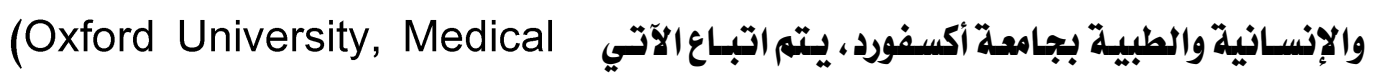
(Oxford University, Humanities Division, ،Sciences Board, 2014:3-5) \& $r q$

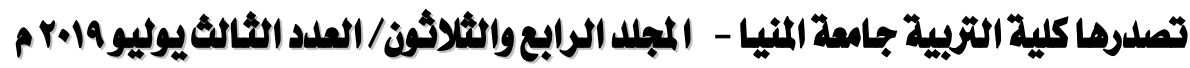
gamel_abdo59@yahoo.com

http://ms.minia.edu.eg/edu/journal.aspx 


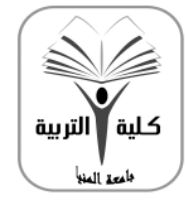

\author{
مجالة البجث في التزبية ومام الثفس \\ كايلة التزبية - جامعة المئيا
}

كلية مُقتملةمن الميئة القومية لضمان جودة التمليم

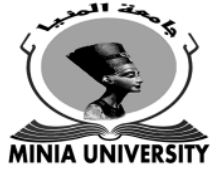

: (Oxford University, Social Sciences Division, 2018:5-6) ،2018:8)

يقع على عاتق المشرف مسؤولية تزويد الطالب بهملومات منتظمة حول تقدمه، وتعرف مستوى الرضا عن العمل معًا؛ للتأكلد من أن الطالب يشعر أنه موجه بشكل مناسب وقادرًا على التواصل مع المشرف، وحيثما تنشأ المككلات لا بلد من تقليم التوجيه واللدم والمساعدة من قبل المشرف والقسي والكلية فيما يتعلق بالإجراءات التصحيحية اللازمة. يقلدم المشرف والطالب تقاريراً حول مستوى وطبيعة العلاقة الإثرافية بينهما، ويجب أن يشير كل تقرير إلى طبيعة تواصل المشرف مع الطالب، كما ينبفي على المشرف تنبيه مدير الدراسات العليا إلى أية مشكلات يواجهها في الإشراف على الطالب. طالب البحث الذي لم يكن راضيًا عن مشرفه في مناسبة واحدة على الأقل في السنة الدراسية التي لم يحرز فيها تقدمًا، تتم مناقثة الأسباب من قبل المجالس الرسمية المختصة، ويمكن إنهاء العلاقة الإشرافية أو وضع إجراءات تصحيحية وفقًا لطبيعة وحجم المشكلات. توضيح التوقعات المتعلقة بساعات عمل الطالب وترتيبات العطلات والإجازات، والتوقعات الطبيعية هي أن يكون الطلاب يعملوز بدوام كامل، ولكن ينبفي للمشرفين أيضاً أن يضمنوا مرونة معقولة فيما يتعلق بـالساعات الإثرافية ومواعيد الاجتماعات؛ لضمان أن تكوز الدراسة متوافقة مع وجود أطفال مُعالين أو أية ظروف أخرى متعلقة بـالجانب الإنساني، وفي الوقت نقسه ينبفي أن تكوز الاجتماعات بـاتفاق مسبق وفقًا لجدول زمني مرن. التزام الشرف بمواعيد الاجتماعات والساعات الخاصة بمقابلة طلاب البحث، والتنسيق والاتفاق مع الطالب على تكرار وملدة الاجتماعات، والسرعة المتوقعة للتعليقات على أعمال الطالب المكتوبة، وإعادة العمل المقلدم بنقل بناء في غضوز فترة زمنية معقولة. يجب أن يكوز المشرف قدوة أخلاقية في الالتزام بأخلاقيات البحث والإشراف العلمي، ويعمل دائمًا على إكساب الطلاب أخلاقيات البحث العلمي، وتقديم الإرشادات والمشورة فيما يتعلق بـالقضايا الأخلاقية الخاصة ببحث الطالب، وحث الطلاب على تجنب الاتتحال العلمي، ومراعاة القضايا المتعلقة بـالملكية الفكرية وحقوق التأليف الطبع والنشر. $\varepsilon r$.

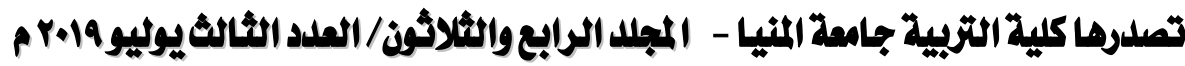
gamel_abdo59@yahoo.com

http://ms.minia.edu.eg/edu/journal.aspx 
ومن أجل استفادة أكثر من الإشراف وضمان علاقة إشرافية مستقرة، يجب على الطالب الباحث السعي لتطوير نهط وبيئة بحثية مناسبة مع مشرفة، بما يحقق علاقة علمية ومهنية وأخلاقية متميزة، كما ينبفي على الطالب أن يناقش مع المشرف نوع التوجيه والتعليقات التي يجدها أكثر فائدة، ويتوافق معه حول جدول زمني للاجتماعات يلتزم به الطرفان، وأن يكوز الطالب على علم بمسؤولياته المشتركة

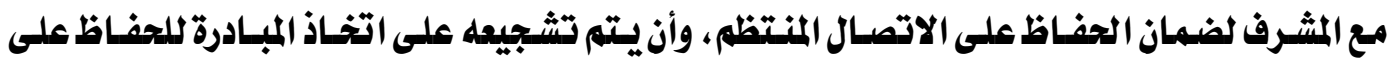
الاتصال والتواصل عند الضرورة، وإبلاغ المشرف عن أية ظروف قد تؤدي إلى انقطاع اللدراسة والبحث، (Oxford University, Policies and وعلى المشرف قبـول الأعذار في الحدود المسموح بها.

Guidance, 2019)

خامسًا : التنمبية المهنية لأعضاء هيئة التلدريس في مجال الإثراف العلمي: تهته جامعة أكسفورد اهتمامًا كبيرًا بعملية التنمية المهنيـة لأعضساء هيئة التـدريس في مجـال الإثراف العلمي/البحثي على طلاب الدراسـات العليـا ؛ حيث تم تصمييم موقفـا إلكترونيـا للإثـراف على البحوث من قبل معهل أكسفورد التعليمي بجامعة أكسفورد "Oxford Learning Institute" لتسهيل وصول طلاب الدراسات العليـا إلى سياسـات واستراتيجيات الجامعة ذات الصلة بنظسام الإثراف البحثي، ويتضمن هذا الموقع ثروة من المعلومات المفيلة لكل من الطلاب البـاحثين والمشرفين، ويقدم الموقع نصائح حول كيفيـة الإثـراف والتعامل مـع طـلاب درجـة الـدكتوراه "DPhil"، ويحتـوي روابـ ذات صـلة بعمليـة الإشراف على البحوث، وبرشد إلى الموارد والمصادر التي قد تكوز مفيدة للباحثين، كما يـوفر أيضًا وجهات نظر معتبرة حول نظام الإثراف بـالجامعة وأساليبه وأنماطه وإجراءاته وسياساته . University of Oxford, Oxford Learning Institute, 2019) وتنقسم كل صفحة من صفحات موقع الإشراف على البحوث بجامعة أكسـفورد إلى ثلاثة أقسـام : "معلومات أكسفورد" وغالبًا ما تتضمن روابط إلكترونية للسياسات والقوانيز ذات الصلة بعملية الإثراف، و"أفكاروأدوات" وتقدم استراتيجيات وأساليب إشرافية يمكن للمشرفين تجربتها، و"حصر للأبحاث والأدب التربـوي في مجـال الإثـراف البحثي" وتقـــم ملخصـات الأبحـاث حـول الموضـوع الإثـراف العلمي وأفضل 


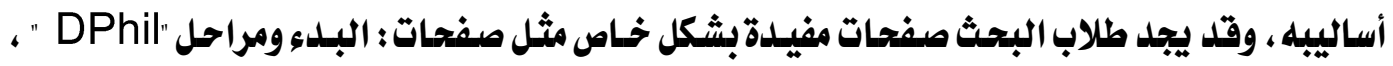

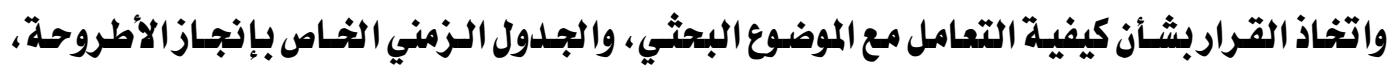
وطبيعة العلاقة بـين الطلاب والمشرفين، ومسؤوليات وأدوار المشرفين والطلاب، وتقدم هـذه الصفحات نصائح حول كيفية العمل مع مشرفك لتجنب المشكلات، بـالإضافة إلى مصادر اللدمم إذا كنت تواجه مشكلات أكاديمية أو غير ذلك، وتطرح معاييرًا للإثراف الفعسال، ونظرة عامة على أسـاليب الإثراف المختلفة، وبـرامج تطوير مهـارات البـاحثين والمشـرفين، وتحليـلـ الاحتيـاجـات التدربييـة، وتـوفر صفحات أخـرى معلومات عز النشر العلمي والعرض في المؤتقرات وإدارة الوقت ك أسساليب للتنمية المهنية لأعضساء هيئة التلدريس والطلاب في مجسال البحث والإثراف العلمي. University of Oxford, Oxford) Learning Institute, 2019) ويجب أن يكـون المجلس المختص بتعييز المشـرفين على علهم بـالترتيبـات المقدمة على جميع المستويات ( القسه / الكلية / الجامعة ) للتنمية المهنية وتلدريب المشرفين ( خاصة المشرفين الجـدد )، وعلى التطوير المستمر للموظفين فيما يتعلق بجميع جوانب الإثراف على البحوث؛ والتأكلد من وجـود نصبيحة (University of Oxford, متاحة للزملاء المشرفين حول احتياجـات التـدربب والتنمية المهنية. ،Research Training ,2019) فقي كليـات قطـاع العلوم الإنسانية والاجتماعية بجامعة أكسفورد تتم التنمية المهنية ورفع كفاءة المشرفين من خلال توفير الدعم والتدريب المناسبيز لأعضـاء هيئة التـلدريس وخاصة الجدلد في أول

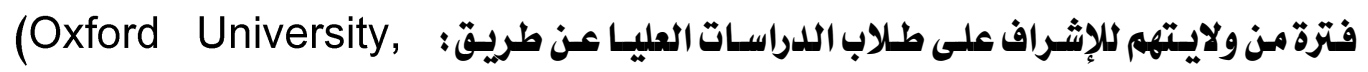
Humanities Division, 2018:3-4) يعين مجلس الكلية مرشلًا يقوم بتقديم المشورة والتوجيه واللدم لأعضاء هيئة التدريس الجدد بشأن الإشراف على طلاب الدراسات العليا. تشجيع جميع أعضاء هيئة التدريس الممينين حليثًا على حضور الدورات التدريبية في مجال الإشراف على طلاب اللدراسات العليا والتي ينظمها معهد أكسفورد التعليمي. \& $\{r$

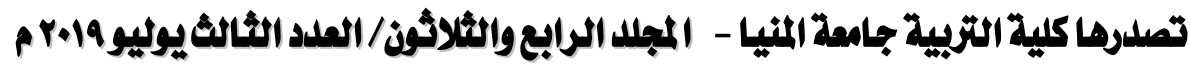
gamel_abdo59@yahoo.com

http://ms.minia.edu.eg/edu/journal.aspx 


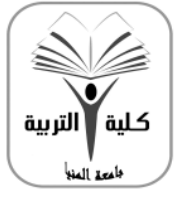

\section{مجلة البعث في التربية وعلم النفس \\ كلية التربية - جامعة المنيا}

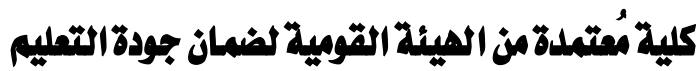

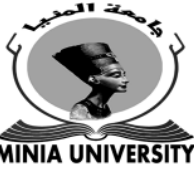

تشجيع جميع الموظفين، وخاصة أعضاء هيئة التدريس على طلب المشورة والتوجيه واللدم من ملير الدراسات العليا ورئيس مجلس الكلية بشأن الإثراف على طلاب البحوث. هيئة التدريس من الخبراء في مجال الإثراف مسؤولة عن ضمان حصول أعضاء هيئة التدريس الجدد على المشورة والتوجيه واللدمى بشأن الإثراف على طلاب البحوث، والثرف المبدئ مسؤونًا عن الحصول على التدريب المناسب في الإثراف البحثي. تبيين عضو متمرس من أعضاء هيئة التدريس كشرف مشارك للشرف المبتدئ، ومن المتوقع أن يعمل العضو المتمرس كمرشد للشرف المبتدئ. يوفر معهد أكسفورد التعليمي حلقة دراسية ودورات تدريبية متخصصة حول الإشراف على الدراسات العليا تكون إلزامية لأعضاء هيئة التدريس وخاصة الشرفين المبتدئين، ويتم تشجييع جميع المعينين الجدد بالإشراف على استخلام المواد والتدريبات المكثفة عبر الإنترنت وعلى موقع الإشراف على البحوث التابع لمعهل أكسفورد التعليمي والثاركة في الحلقة الدراسية حول الإشراف على الطالاب. أما في كليات قطاع العلوم الطبيعة والطبية بجامعة أكسفورد يلزم التدريب للمشرف المبتدئي، ويوفر معهد أكسفورد التعليمي إرثادات مهمة حول الإشراف على الأبحاث على موقعه على الويب، ويككن

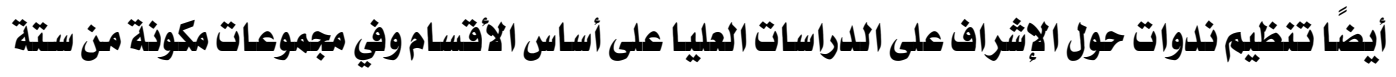

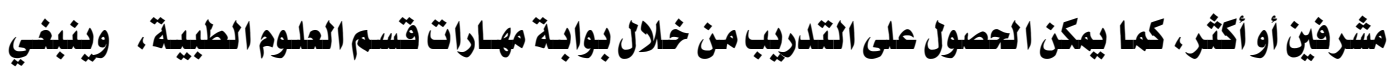

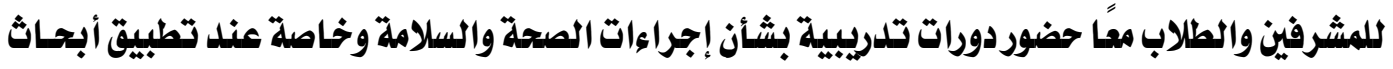
ميدانية متعلقة بالبشر ب بهلف تعرف المسؤوليات القانونية عن الأمن والسلامة، كما يمكن الحصول على المورة بشأن المسؤوليات القانونية عن السلامة من موظف السلامة بالجامعة، ويقدم مكتب السلامة بكل

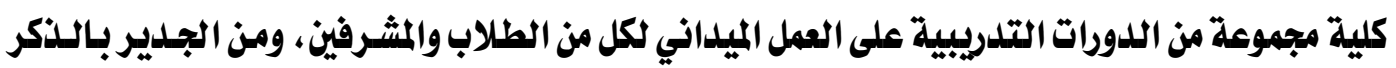
أن لكل كلية من كليات الجامعة ترتيباتها وإجراءاتها الخاصة لتنفيذ السياسات الخاصة بالأمن والصحة

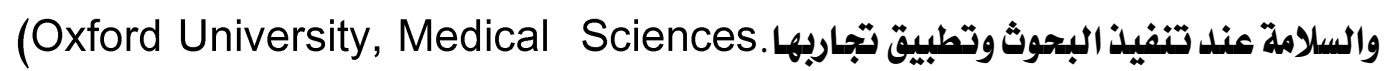

Board, 2014:2-6)

وممسا سبق، يتضـح أن أهم أسـاليب التنميـة المهنية في مجـال الإثـراف العلمي بكليـات العلوم $\varepsilon r r$

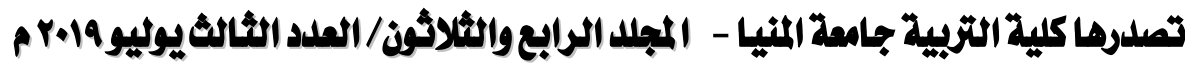
gamel_abdo59@yahoo.com

http://ms.minia.edu.eg/edu/journal.aspx 
الإنسانية والاجتماعية والطبيعية بجامعة أكسفورد هي : تدشين موقفما إلكترونيًا يقدم كل مـا هو مفيد وجلديل حول الإثراف العلمي، وحضور دورات تدريبية يقدمها معهد أكسفورد التعليمي وخاصة للمشرفين الجدد المبتدأين، ونقل وتبادل الخبرات من المشرفين القدامى للمشـرفين الجـدد من خلال المشاركة مفًا في الإشراف، أو من خلال تعييز الجامعة والكليـات مرشـدين من ذوي الخبرة في مجـال الإثـراف لإرشــاد هؤلاء المشرفين في كل ما يتعلق بعملية الإثراف على البحوث. ثانياًا : الإشراف العلمي بجامعة نيو سوث ويلز بسيدني الأسترالية:

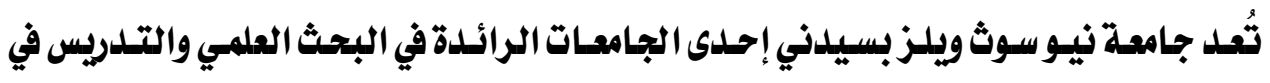
أستراليا، وتفخـر الجامعـة بـالنطـاق الواسع والجـودة العاليـة لبرامجهـا التعليميـة والبحثيـة، ويكتسب تعليمهـا القـوة من أنشطتها البحثية وروابط الصناعة القويـة وطابعهـا الـدولي؛ حيث لـليها شـراكات واتفاقيات إقليمية وعالمية قوية مع جامعات ومؤسسات تعليمية وبحثية وصناعية مشهورة، كما تتمتع الجامعة ببيئة أكاد يمية وبحثية تسمح للطلاب والباحثين أن يكونوا مصدر إلهام للتميز في برامج الدراسة The University of New والبحث، وتسمح الشراكات مع المجتمعات المحلية والعالمية لجامعة بمشـاركة المعرفة والنقاش والبحث، وتلتزم الجامعة بحمايـة الحريـة الاككاديمية للطاب والباحثين بـاعتبارها ضرورية للتدريس السليم والبحث العلمي القوبم والمعرفة ذاخل الجامعة، ويتجلى هلا الالتزام في سياسات وقوانيز الجامعة التعليمية والبحثية. The University) .of New South Wales, abaut UNSW, 2019)

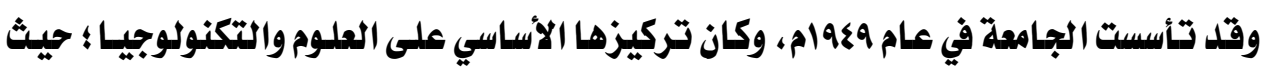
تفخر جامعة نيو سوث ويلز (UNSW) بإحداث فـارق حقيقي في المجتمع الأسترالي من خلال البحوث الرائدة والتعليم الذي يقدمه الخبراء من الباحثين وطلاب الدراسات العليا، كمـا أن الجامعة عضو مؤسس

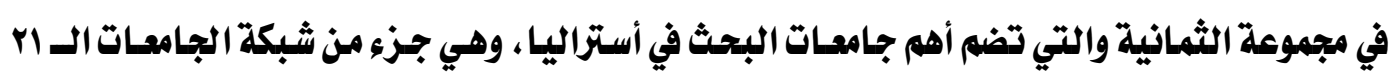
الموقرة، يـأتي إليها أكثر من ( •0 ) ألف طالب من ( IrA ) دولكة مختلفة، وتحتفظ الجامعة بخدمة الـلدم التعليمي والبحثي الدذي يمكنها من مساعدة الطلاب والبـاحثين في الأداء الاككاد يهي والبحثي والصحة

\section{$\varepsilon \Psi \varepsilon$}

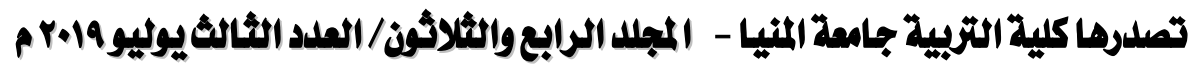
gamel_abdo59@yahoo.com

http://ms.minia.edu.eg/edu/journal.aspx 


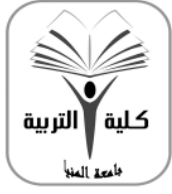

$$
\text { كجالة البحث في التزبية وملم النفسل }
$$

كايلة مُتملمدة من الميئة القومية لضمان جودة التمليم

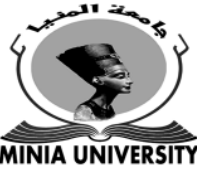

والرفاهية والأداء المالي وغير ذلك، ويوجد لجامعة نيو سوث ويلز (UNSW) ثمانية فروع مختلفة، وتتمركز معظم الكليات في الحرم الجامعي الرئيس في سيدني (UNSW, 2019) . كما تعلد جامعة نيو سوث ويلز من أفضل الجامعـات في أستراليا ؛ حيث تم تصنيفها في الترتيب

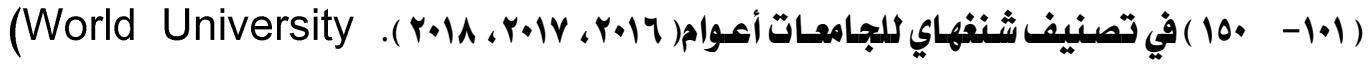
Rankings, Shanghai Ranking, 2018) ، وفي تصنيف كيو أس "QS" الأسباني جـايت

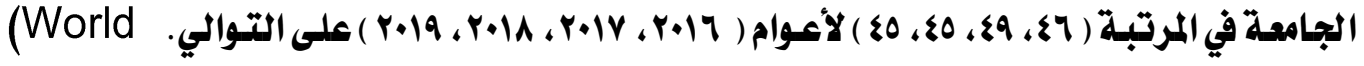
(University Rankings, "QS" Ranking, 2019) وعليه كانت الجامعة حَريـة بـالاختيـار. للمقارنة ودراسة نظام الإشراف العلمي على طلاب الدراسات العليا بها، بـاعتبارها جامعة بحثية رائدة في مجالات التكنولوجيا والصناعة ومجالات حيوية أخرى، ويمكن تناول الإثراف العلمي بهلذه الجامعة من خلال المحاور المختارة للبحث، وذلك على النحو الآتي: - إدارةوتنظبيم الإشراف العلعي:

تلتزم جامعة نيو سوث ويلز بالتميز والجودة في الإثراف على بحوث الدرجات العليـا ( الماجستير

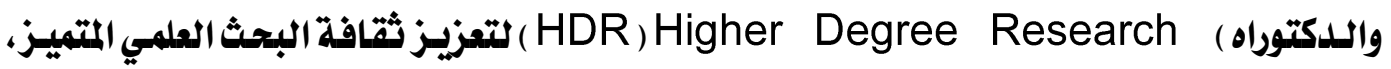
وتخريج مرشتحين "HDR" كبـاحثين مستقلين قـادرين على إنتـاج بحوث جيـلة أصيلة، وذلك من خلال

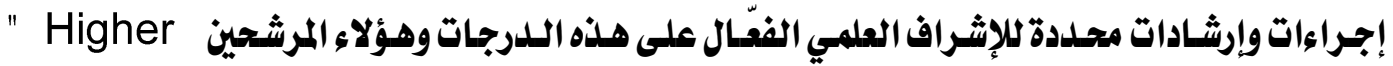
" Higher Degree Research وDegree Research Supervision Procedure" : حيث إن الفرض من هذه الإجراءات توفير مبـادئ وإرثـادات للمشرفيز

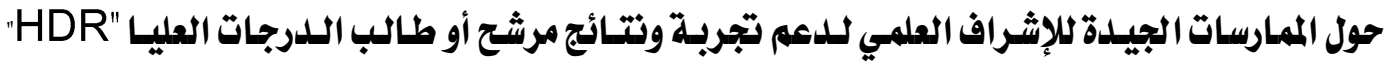
الأعلى جودة، وتُكِل هده المبادئ التوجيهية سياسة الجامعة العليا للرقابة على البحوث، وتُّطبق هـده المبـادئ على جميـع المشرفين المعينين من قبـل إدارة المهوارد البشـرية بـالجامعة وجميـع مرشتحي ( بـاحثي ) اللدراسات العليا المسجلين حاليًا، وتحلد هذا الإجراءات والإرثادات فئات المشرفين على بحوث ( HDR ) ومعايير الأهلية للإشراف، وإجراءات التعيين والاستبلدال وأدوارومسؤوليات المشرفين والطلاب. -Pro) 


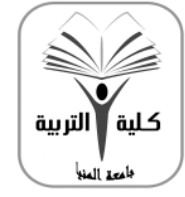

\author{
مجلة البحث في التزبية وعلم النفس \\ كلية التزبية - جامعة المنيا \\ كلية مُقتملةمن الميئة القومية لضمان جودة التمليم
}

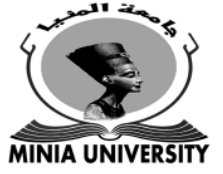

(Pro- „Vice-Chancellor ,Research Training, Version: 1, 2018, 1-6)

Vice-Chancellor ,Research Training, Version: 2, 2018, 2-9)

ويتولى مجلس الجامعة، ومجالس الدراسات العليا بالجامعة والكليـات، ومجـالس الأقسـام إدارة

وتنظيه الإثراف العلمي على البحوث في نيو سوث ويلز، ويصلر ملير ملرسة الدراسات العليـا أو المنسق أو

العميدل المشارك للبحث والتدريب أو ما يعادله توصية إلى عميل أبحاث الدراسـات العليـا ( نائب رئيس الجامعة للدراسات العليا والبحوث ) بتعيين مشرف أول أو ثانوي أو مشترك أو ( هيئة/ فريق إثراف ) لكل مرشع، ويجب أن تكون توصية التعيين على أساس النصاب والأحمال الإثرافية والمواردوالخبرات المتاحة

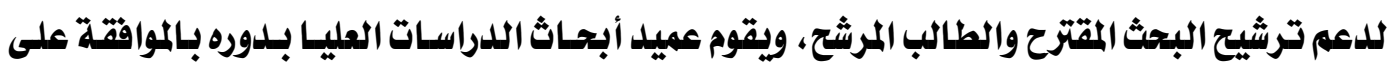

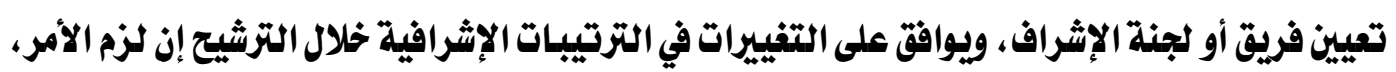

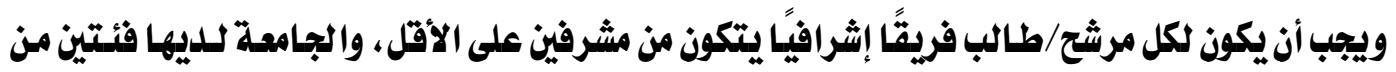

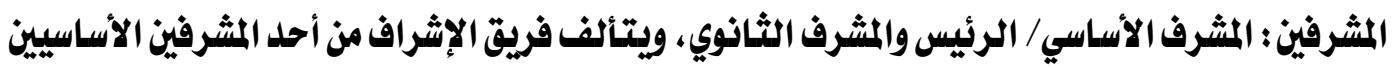

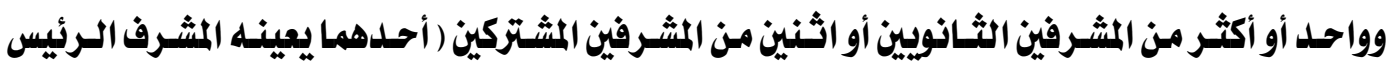

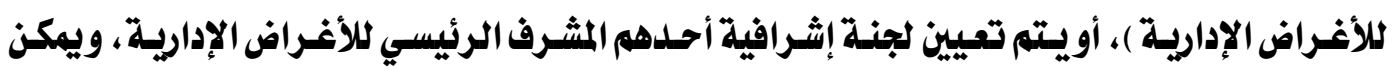

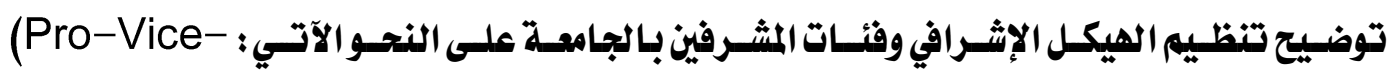

.Chancellor, Research Training Version: 1, 2018, 1-4)

أ- المشرف الرئيس أو الأساسي: ويتحمل المسؤلية الاكاديمية الأساسية عن ترشيح أبحاث درجة

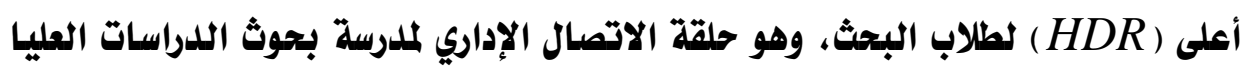

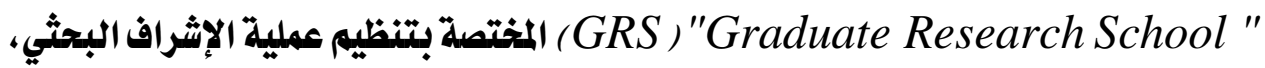

$$
\text { ويتم تعيينه من قبل ملير مدرسة الدراسات العليا أو الكلية. }
$$

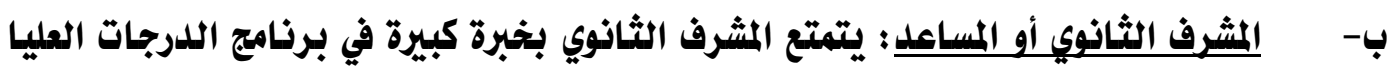
وأبحاثها وهو متاح كمستشار للطالب خلال فتزة الترشيح والعمل في الأطروحة.

الإشراف المشتك؛ يتم تعيين اثنين من الشرفين المثتركين اللين يتحملون مسؤولية متساوية -

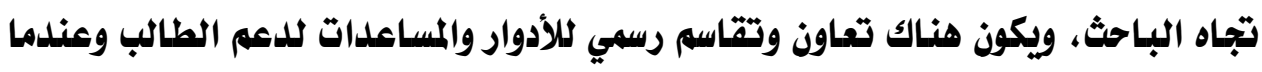

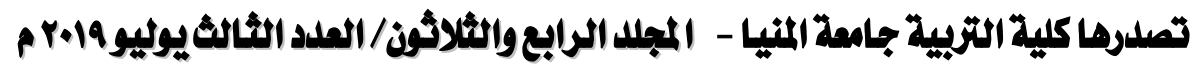
gamel_abdo59@yahoo.com

http://ms.minia.edu.eg/edu/journal.aspx 
يختار الطالب مشروع بحثي متعدد التخصصات، فالشرفين المشتركين لليهم خبرة في جوانب

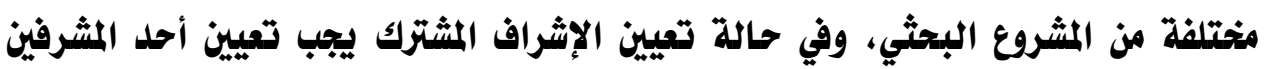
الشتركين كشرف أول أو رئيس، ويجب أن يستوفي معايير الأهلية للشرف الرئيس كما سيوضحها

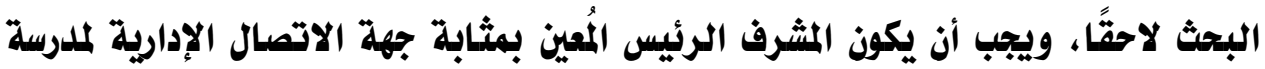
الدراسات العليا GRS، وليس هناك ضرورة لتعيين مشرف ثانوي ما له يكن مناسبًا للبحث.

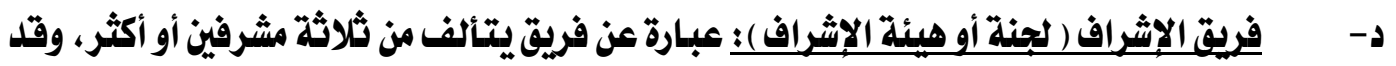

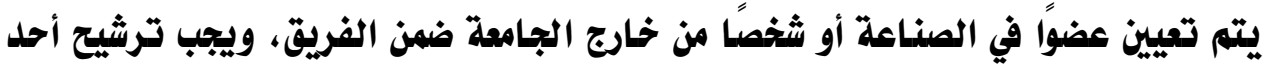
أعضاء الفريق كمرف أول/ أساسي، وباقي أعضاء الفريق كشرف ثانوي، ويجب أن يتعرف

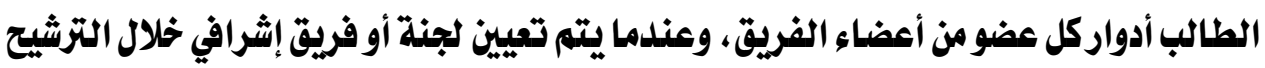

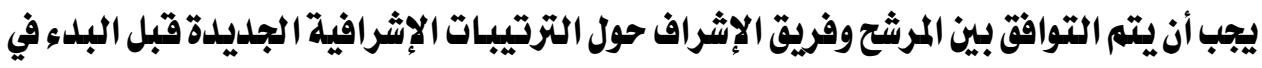

$$
\text { مشروع البحث. }
$$

وتنظم المجالس المختصة بالجامعة والكليـات والأقسام الاكاد يمية مع عميد اللراسات العليا

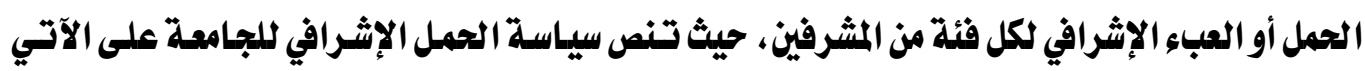
:(Pro-Vice-Chancellor, Research Training Version: 1, 2018, 4)

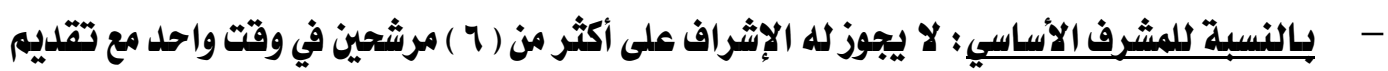
إثبات الوقت الكافي للإثراف ومراعاة مسؤوليات التدريس والبحث والإدارة، وأن يكون للديه سجئًا

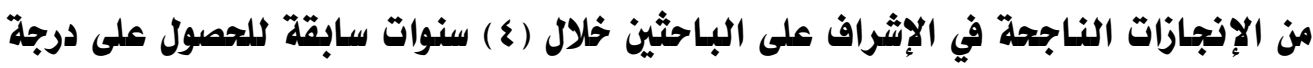
الدكتوراه أو سنتين للحصول على درجة الماجستير ، بالإضافة لمواققة ملير ملدرسة الدراسات العليا.

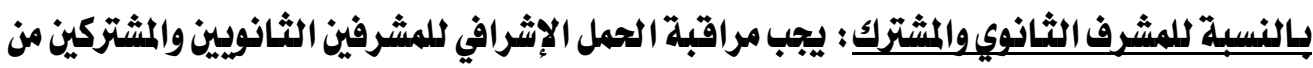

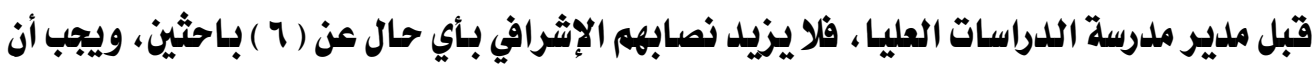
يُؤخذ في الاعتبار تحليد الوقت الكافي للإشراف مع مراعاة مسؤوليات التدريس والبحث والإدارة؛

$$
\text { ويوافق على الإثراف ملير الملدرسة أو عميد الدراسات العليا. }
$$

وفي ضوء رقابة ومتابعة الحمل الإشرافي والأداء التوجيهي للمشرفين يُزود عميد الكلية المشـارك \& $r v$

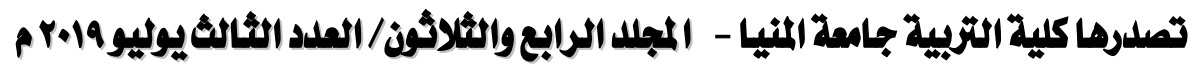
gamel_abdo59@yahoo.com

http://ms.minia.edu.eg/edu/journal.aspx 
للبحث والتدريب من قبل عميل أبحاث الدراسات العليا بتقارير حول الأحمال الإثرافية وأداء المشرفين، وتقوم الكليات بإدارة أداء المشرف بشكل استباقي بمـا يتماشى مع توقعـات الجامعة، وتنظمه جـامعة نيو سوث ويلز عملية إضافة أو استبدال أو تفيير مشرف بشكل سليه مع وضع إجـراءات واضحة، وفقًا للحسالات الآتية :. (Pro-Vice-Chancellor, Research Training Version: 2, 2018, 4)

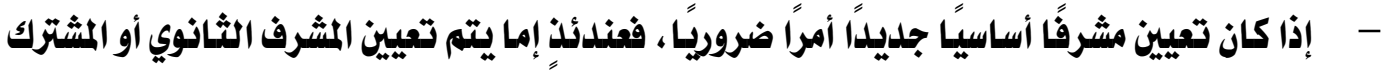
أو المشرف البديل المؤهل كمشرف أساسي، ويجب مناقشة ملى ملاءمته ومناسبته مع المرثح، ويته تقييم مثل هذه الأمور على أساس كل حالة على حده لضمان دعم المرشح بشكل مناسب. في حالة حدوث توتر وانهيار للعلاقة الإثرافية، ينبفي إجراء محاولات الوساطة من قبل ملير ملدرسة الدراسات العليا أو عميد أبحاث الخريجين، ويجب إخطار العميد المشارك للبحث والتلدريب أو ما يعادله في الكلية بـالمككلات التي نثأت والمشاركة في الوساطة إذا كانت المشكلة غير مقدور على حلها من قبل الملدرسة، ويجب الاتصال بعميد أبحاث الدراسات العليا إذا لم يكن من الممكن الحل للوساطة على مستوى الكلية، وفي الحالة الأخيرة يمكن استخلام وسطاء مستقلين، وإذا لزم الأمر

$$
\text { تفيير المشرفين. }
$$

- عند علدم القدرة على تحليد مشرف بلديل خلال إطار زمني معقول، قدل يطلب عميد أبحاث الخريجين من المرشح أن يـأخذ إجازة أو قد يوقف الترشيح، على أن يتم إعادة القبول وفقاً لإجراءات القبول

\section{المتبعة.}

مما سبق، يتضـ أن عملية إدارة وتنظيم الإشراف العلمي بجامعة نيو سوث ويلز تمتم من قبل جهات رسمية مختصة على مستوى الجامعة والدراسـات العليا والكليسات وملدارس الدراسـات العليـا التي يسجل بها المرشحوز للدرجات العليا، وأنها عملية شاملة تخص تمييز المشرفين بفئاتهم المختلفة( أساسي،

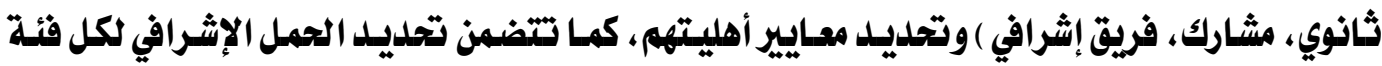
ومراقبته ومتابعته ، وإجراءات تفيير واستبلدال وإضـافة مشرفين على الطلاب المرثحين ؛ ومن ثم ضمان حسن سير عملية الإشراف وتلقي المرشح للدعم والتوجيه والمساندة لإكمال مشروعه البحثي بنجاح. $\varepsilon \Psi \Lambda$ 


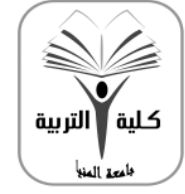

مجلة البعث في التزبية وعلم النفس

$$
\text { كالية التربية - جامعة المنيا }
$$

كلية مُتملدةمن الميئة القومية لضمان جودةالتمليم

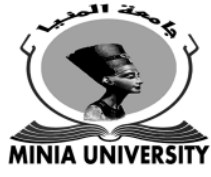

r - معايير اختيار الشرفين وتشكيل لجان الإشراف العلمي:

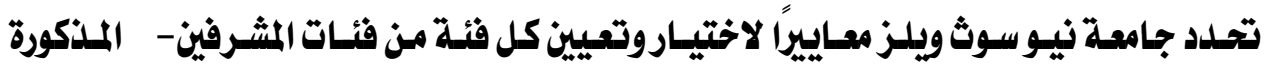

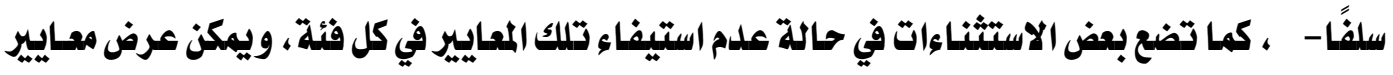

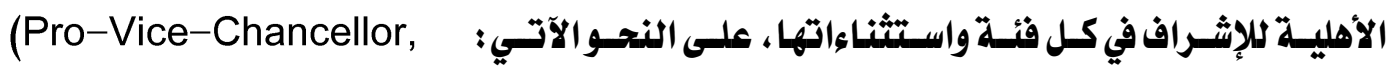
:Research Training Version: 1, 2018, 2-4) أ- الشـرف الأساسي: عضو هيئة التـدريس المؤهل لتعيينه كمشرف أساسي لمرشح HDR ينبفي أن يستوفي المعايير الآتية:

يكون موظفًا بلدوام كامل أو جزئي في UNSW كمضو في هيئة التدريس.

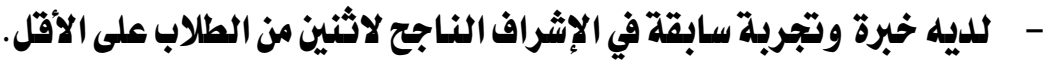

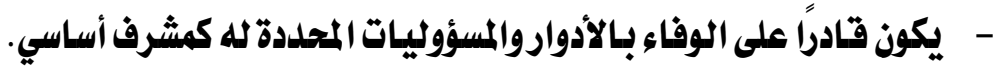
- تجاوزت ملدة خدمته الاكاد يمية بالجامعة المدة المتوقعة في الإثراف على أكثر من مرشحين. - لديه عقد عمل في مدرسة الدراسات العليا التي يتم فيها تسجيل المرشح أو طالب البحث. - يتمتع بمستوى عال من الخبرة في مجال التخصص وموضوع البحث المقترح الإشراف عليه. - - للديه مشاركة نشطة ومستمرة في البحوث بجامعة نيو سوثوث ويلز. - يحمل درجة الدكتوراه أو لليه خبرة بحثية مكافئة لهذه الدرجة.

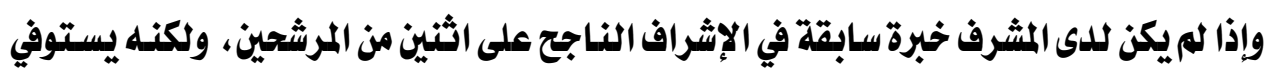

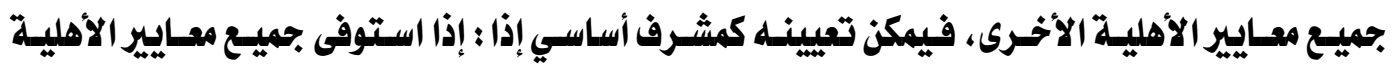

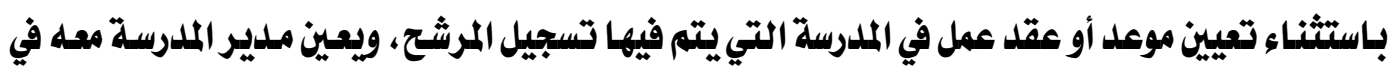

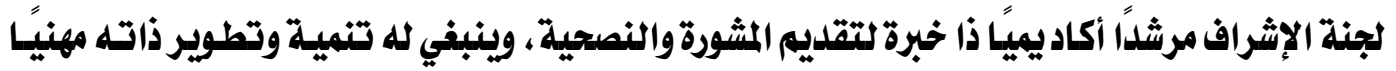

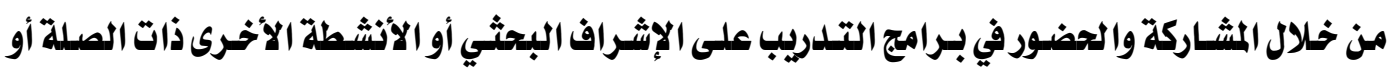

استيفاء أية متطلبات أخرى يحددها ملير ملدرسة اللراسات العليا من أنشطة التنمية المهنية أو غيرها.

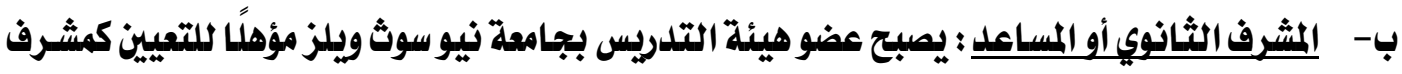
ثانوي أو مساعل إذا استوفى المعايير الآتية : $\varepsilon r q$

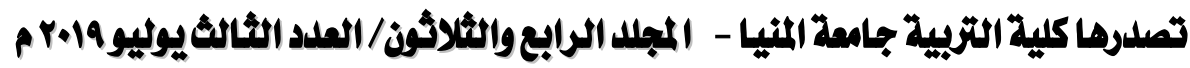
gamel_abdo59@yahoo.com

http://ms.minia.edu.eg/edu/journal.aspx 


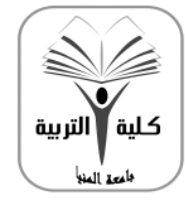

\author{
مجالة البجث في التزبية ومام الثفس \\ كايلة التزبية - جامعة المئيا
}

كلية مُقتملةمن الميئة القومية لضمان جودة التمليم

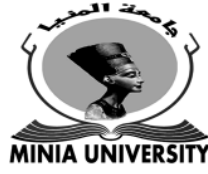

- - أن يكون لليه دوام أو موعد بملدرسة الدراسات العليا ويستوفي شروط الأهلية للتعيين كمشرف. - حاصل على درجة أستاذ فخري ، ولديه عقد أوزيسارة أو تعيين فخري بـالجامعة، أو تقاعلد ومازال نشطًا في مجال البحث.

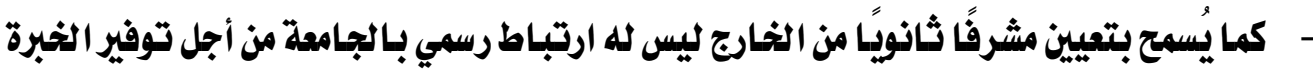
الميلانية للمشروع بحثي، وذلك عندما يكوز من المخطط أن يقضي الطالب المرشح بعض الوقت في مختبر أو مصنع خارجي كجزي من التعاوز المشترك مع الجامعة، ويمكن أذ يكوز هؤلاء المشرفين الخارجيين بـاحثين في مؤسسات مثل : الإدارات الحكومية، ومعاهل البحوث، الملدارس، والمكتبات، والمتاحف أو الصناعة ....إلخ. ج- المشرف المشتك : يتم تعييز مشرفيز مشتركين على طلاب اللدرجات العليا، و ذلك بعد تقوافر المعايير والشروطالآتية:

يجب أن يكوز أحدهم من داخل الجامعة ويستوفي شروط التعيين كمشرف أول/ أساسي. يجب على المشرف الثشتك من خارج الجامعة أن يستوفي شروط التعييز كمشرف. إذا كان المشرف المشترك الذي لم يتم تعيينه بصفة أساسية هو أحلد موظفي جامعة نيو سوث ويلز، يجب أن يكوز حاصلاً على درجة الدكتوراه أو ما يعادلها، وأن يكوز له مشاركة نشطة ومستمرة

$$
\text { في الأبحاث بالجامعة. }
$$

ويستبعل من الإثراف على طلاب البحوث واللدرجات العليـا عضو هيئسة التدريس غير المؤهل، وحال وجود تضـارب في المصـالج بينه وبـيز المرشت، أو يكوز ليس على مستوى الالتزام المستمر المطلوب للدم الطالب المرشح، وفي جميع الأحوال يجب أن يكون المشرف شخصًا مناسبًا لتقديم الإثراف واللدمم والوفـاء بـالأدواروالمسئوليـات، وفي حسالات نـادرة يجـوز للجـامعة إزالـة أو تعليق مشـرف من دوره وعمله الإشرافي إذا لم يفِ بأدواره ومسئولياته ، ويقوم عميد أبحاث الخريجيز ( عميـل الدراسـات العليـا ) بـإبلاغ المشرف وتزويلده بـأسباب القرارو إعطائه فرصة الرد، وهذا ينطبق على جمييع فئات المشرفين. وباستقراء معايير الأهلية لاختياروتعيين جميع فئات المشرفين في جامعة نيو سوث ويلز، يتضح أنها تتمحور حول أن يكون المشرف عضواً بـا الجامعة، ويعمل بـدوام كامل أو جزئي، وأن يكون ذا خـبرة في

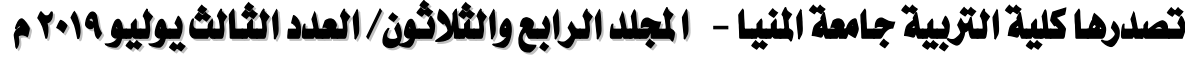




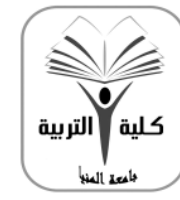

$$
\text { مجلة البجث في التزبية وملم النفس }
$$

كالية مُتملمة من الميئة القومية لشمان جودة التمليم

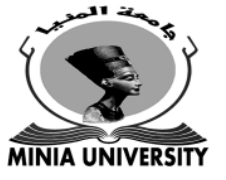

مجال الإشراف، نشطًا في مجال البحث العلمي، قادرًا على الوفاء بمهامه ومسئولياته الإشرافية.

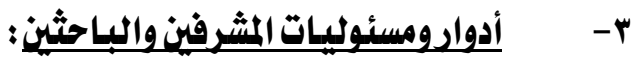

تحدد وثيقة التميز الإشرافي ودليل إرشادات الإشراف العلمي الفعال بـالجامعة- والمُشار إليهمـا

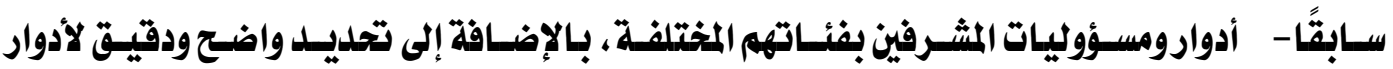
ومسئوليات الطلاب البـا حثين خلال عملية الإثراف ومراحل البحث المختلفة، ويمكن توضيح ذلك على

$$
\text { النحو الآتي: }
$$

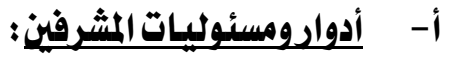

تتحلد من خلال الوثائق المنظمة للإثراف العلمي بـالجامعة أدوارومسئوليات كل فئة من المشرفين، كمـا

يلي: (Pro-Vice-Chancellor ,Research Training, Version: 1, 2018, 4-5).

(Pro-Vice-Chancellor ,Research Training, Version: 2, 2018, 2-9)

- -

الاتصال والتواصل الإداري مع الجامعة في جميع المسائل والثكلات المتعلقة بـالإثراف على الطلاب

$$
\text { المرشحيز للدرجات العليا. }
$$

التأكل من أن المرشح ( الطالب ) يفهم حقوقه والتزاماته بموجب سياسة أبحاث الجامعة، بما في

ذلك ملونة السلوك الخاصة بـالبحوث وسياسة الملكية الفكرية الخاصة بجامعة نيو سوث ويلز. ضمان أن المرشح على دراية وفهم بسياسة الصحة والسلامة في بحوث (UNSW) وخاصة في

$$
\text { الأبحاث الميدانية. }
$$

تقليم الثشورة الرسمية بشأن تقدم الطالب في بحثله إلى ملير ملدرسة اللدراسات العليا وعميل أبحاث الخريجين خلال عملية الاستعراض لتقارير الأداء البحثي سنويًا بالجامعة. التأكلد من أن غيابهم من الجامعة لمدة تزيلد عن ( ) أسابيع يتم تغطيته من قبل المشرف الثانوي أو من قبل عضو هيئة التدريس آخر إذا كان المشرف الثانوي أو المثتك غير متاح ( أو ليس عضواً في هيئة التدريس بـالجامعة )، ويشمل ذلك فترات الإجازة المعتمدة مثل إجازة التفرغ البحثي أو الوقت في الخارج ؛ ويجب أيضا إبلاغ المرشح بذلك مسبقًا. « $\leqslant$

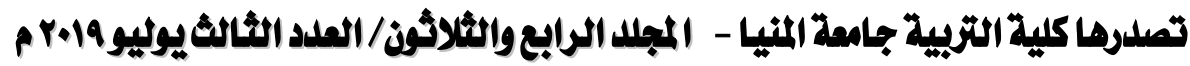
gamel_abdo59@yahoo.com

http://ms.minia.edu.eg/edu/journal.aspx 


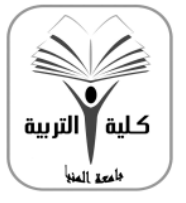

\section{مجالة البجث في التزبية وملم النفس \\ كايلة التزبية - جامعة المثيا}

كايلة مُتملمدة من الميئة القومية لضمان جودة التمليم

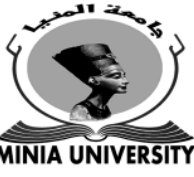

تقليم المشورة لملير الملدرسة بشأن تعييز ملققي الأطروحات في أقرب وقت ممكن بعد أذ يضع

الطالب إشعاره بنية تقلديم الأطروحة لعملية المناقشة والفحص.

الإقراربعد مراجقته لكامل الأطروحة أنها في الشكل الصحيح للفحص والمناقشة.

- المشرفوز الثانويهوز أو المساعدوز : وتتمثل أدوارهم ومسئولياتهم في الآتي :

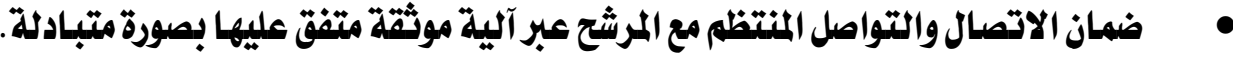

• العمل في مجال التوجيه واللدمم والإرشاد للمرشحين أو المشرفين المشاركين عند الطلب.

• العمل بلديًا من المرف الرئيس أو الأساسي عند غيابه عن الجامعة.

• تقديم ملاحظات للمرشح خلال المراجعة السنوية لتقارير الأذاء.

- الفرق الإشرافية والإثراف المشترك : وتتمثل أدوارهم ومسئولياتهم في الآتي:

• الالتزام بـالمبادئ الواردة في سياسة الإشراف على بحوث اللدرجات العليا خلال عمليات التوجيه

واللدعم والمساندة للمرشح.

تقلديم المشورة ودعم المرشح لإكمال برنامج بحثي متميز في الوقت المناسب.

وبصفة عامة هناك دور إداري تنظيمي للمشرفين بشأن ردود الفعل والتواصل مع الطلاب المرشحين

للبحث تتمثل في : وضع خطة اتصال مع مرشح HDR تقضمن جـداول اجتماعـات الإثراف، ووضع جـدول

أعمال مقترح لكل اجتمـاع، وتدوين ملاحظـات بمكن أن تجنب الاجتماعـات واللقـاءات المتكررة، وتدبير

الترتيبات الخاصة بـدعم وتوجيه الباحث عندما يكون المشرف في إجـازة ويكوز ذلك جزيءًا من المخطط

الإثرافي، ويجب على المشرفين والمرشحين القيام بلذلك والتوافق حول المبـادئ والمواعيـل النهائية لتقديم

المسـودات الأوليـة والنهائيـة لأجـزاء الأطروحة وردود الفصل حول المسيـودة النهائية. -Pro-Vice)

Chancellor ,Research Training, Version: 2, 2018, 3)بـالإضـافة لهــذه الأدواروالمسئوليـات الفنيـة الاكاد يميـة والإداريـة التنظيميـة، هنــاك أدوار ومسئوليات أخلاقية للمشرفيز تجاه الباحثين؛ لتعضيد السلوك البحثي والأخلاقي القويه خلال مراحل البحث المختلفة، حيث يقوم المشرف من خلاهدا بالآتي: Research, Training, Version: 1, 2018, 2) - $\leqslant \xi$

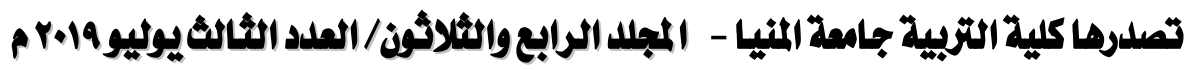
gamel_abdo59@yahoo.com $\quad \underline{\text { http://ms.minia.edu.eg/edu/journal.aspx }}$ 


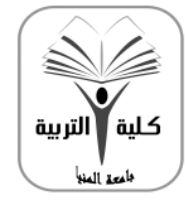

\section{مجالة البجث في التزبية ومام الثفس \\ كاية التزبية - جامعة المنيا}

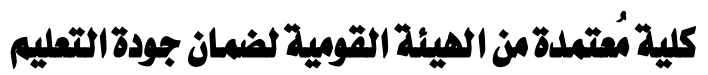

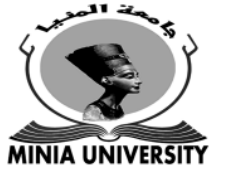

تشجيع الباحثين على اتباع قواعد السلوك والسياسات المتعلقة بـالممارسات الأخلاقية للبحوث. يناقش مع مرشحيه ما إذا كانت أبحاثهم تتطلب الحصول على مواققات أخلاقية ومواقتات أخرى ذات صلة والتأكل من استيفائها قبل بلدء البحث أو إجراء الدراسة اليدانية. يقوم المشرفوز بتوجيه مرشحي HDR لتطوير خطط جمع البيانات والمواد التي تم إنشائها مز الششروع البحثي، وتخزينها واستخدامها في ضوء قواعد وأخلاقيات البحث العلمي. ومن الجـلير بـالـدكر أن الجامعة تحلدد دورا للمشرفين في إعلداد المرشع وأطروحته للمناقشة والفحص وترتيب إجراءات ذلك مع الطالب ولجنة المناقشة، فيجب أن يكوز المشرفوز على درايـة بعمليـات التقليم والاختباروالجداول الزمنية المحلددة لذلك، وينبفي دعم المرشحين في تلبية متطلبات الجامعة في هذا الشأن، ومن ثم يجب أن يكوز للدى المشرفين فهمًا ثـاملًا لإجـراءات المناقشة والفحص ؛ من أجل فحص الأطروحة بشكل مستقل وخالٍ من التحيز، كما أن المشرفين بحاجـة إلى تعضيد وفهم سياسة (UNSW) لعلم تضارب المصالج بـالجامعة ؛ لضمان إعطاء النصيحة الصحيحة للمرشتحين حول الفاحصين المحتملين لأطروحاتهه ، كما يجب أن يتوافق المشرفوز والمناقشون على العدل والإنصاف كنهج لتقديم كل ردود الفعل

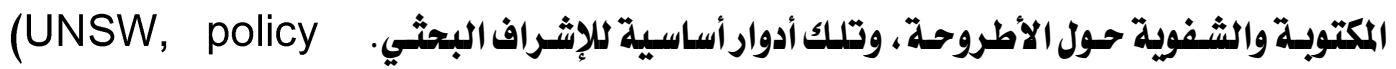
.thesis Exam, 2019:6) مما سبق، يتضح تعلدد وتتنـوع مسئوليات وأدوار المشرفيز بجامعة نيـو سوث ويلز مـا بـيز أدوار ومسئوليات علمية منهجية وفنية، وإدارية تنظيمة، وأخلاقيـة إنسانية، كمـا يسبرزدورًا مهمًا للمشرف في عملية مناقشة وفحص أطروحة الطالب من حيث اختيـار المناقشين، وترتيب إجـراءات المناقشئة، والنهج الذي تسير عليه ؛ ضمانًا لموضوعية وعدالة المناقشة والفحص. ب- أدوارومسئوليات الطالب البياحث: أما عن أدوارومسئوليات الطالب الباحث في عملية الإثراف بجامعة نيـو سـوث ويلز، فتتلخص هذه الأدواروالمسئوليات في الآتي: Research Training , هice-Chancellor , اك Version: 1, 2018, 5) 


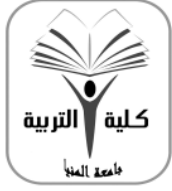

\author{
مجلة البعث في التزبية وعلم النفس \\ كالية التربية - جامعة المنيا
}

كلية مُتملدة من الهيئة القومية لضمان جودة التعليم

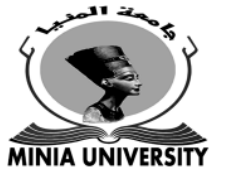

ا- حضور التدريبات اللازمة للبحث، والالتزام بالبادئ الواردة في سياسة الإثراف على بحوث اللدرجة

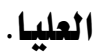

r- - إجراء البحوث الخاصة بششروعه تحت إدارةوتوجيه مشرفه وفي ضوء ترتيبات إثرافية معتمدة. r- ب الثشاركة وإبداء الرأي في تحديد أعضاء الفريق الإثرافي على أطروحته، حالة تفييي الإشراف. ع- إكمال برنامج بحث أصيل ومجدي في الوقت المناسب.

وبالطبع هذه الأدوار بالإضـافة لكون الطالب المسئول الرئيس بالتشارك مي المشرف في إنجاز

أطروحته ، بما يتضمنه ذلك من اختيار موضوع البحث، وجحم البيانات، وإعداد خطة البحث تحت إثراف

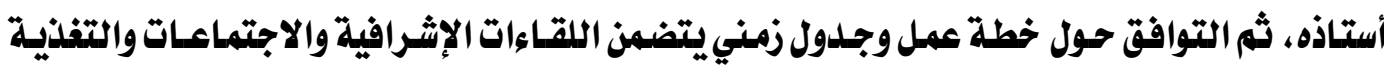

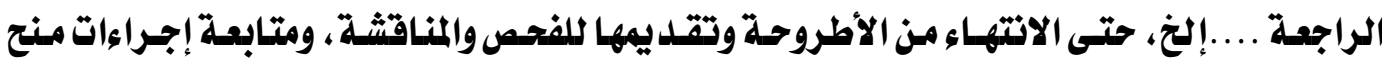
الدرجة العلميـة الأعلى، وفي ضوء تلك الأدواروالمسئوليات الكبيرة للششرفين والبـاحثين خلال مراحل البحث المختلفة، يجب أن يكون لديهما مؤهلات ومعارف ومهارات تتناسب مع أدوارهما ومسئولياتهما، فالثشرفون مسؤولون أمسام المؤسسة البحثية وملير الدراسـات العليـا عن أدائهم لتلك الأدوار،كمها أنهه

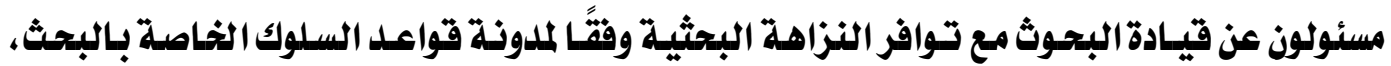

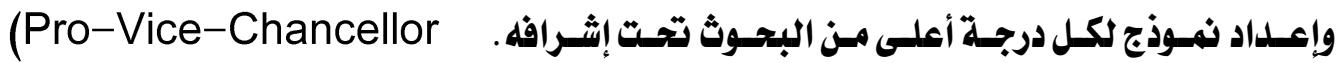
,Research Training, Version: 4, 2016, 1) ومن ثم يتضح تعلد الأدواروالمسئوليات لكل من المشرف والبـاحث خلال العملية الإثـرافية والمراحل المختلفة للبحث، وتحليد تلك الأدواروالمسئوليات وتوصيفها بسياسات ووثائق الإثراف البحثي

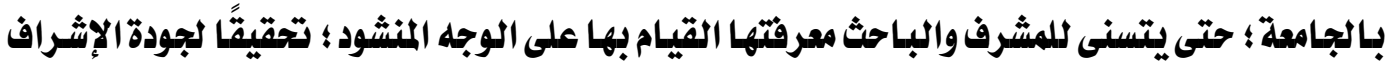
ومن ثم جودة المخرجات البحثية من الرسائل العلمية.

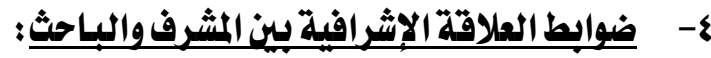
يضع القانون الأسترالي للسلوك البحثي المسؤول إطـارًا بحثيًا وأخلاقيًا يـوفر الأساس لبحوثي

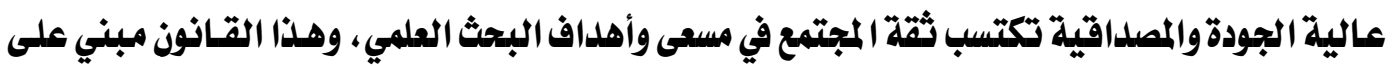
أسس وقواعد توضح المبادئ والمسؤوليات العريضة التي تلدم إجراء البحوث الأسترالية، وتم تطوير هذا $\varepsilon \varepsilon \varepsilon$

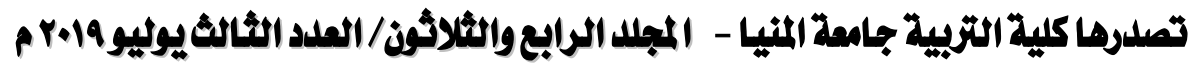
gamel_abd059@yahoo.com

http://ms.minia.edu.eg/edu/journal.aspx 
القانوز عام 1 ا•rم من قبل المجلس الوطني للصحة والبحوث الطبية وجامعات أستراليا والاتحاد الوطني للتعليه العالي ومجلس رابطات الدراسات العليا الأسترالية والمجلس الأسترالي للبحوث العليا، وله أهمية واسعة في جميع التخصصـات البحثية، ويُعـد الالتزام بمـا جـاء في هـا القـانون شرطًا أساسيًا للتمويل البحثي من قبل المجلس الوطني للصحة والبحوث الطبية.

ولإرساء دعائم العلاقة الإشرافية يتم رصد مستوى رضسا الطلاب عن الإثراف العلمي من خلال استبيانات لقياس الرضـا وملدى الاستفادة من المشرفيز، مع وضع إجـراءات تصحيحية في ضوء التفليـة الراجعة لنتائج هذه الاستبيانات، ويتضمن القانوز مبادئ تلدم أية علاقة إشرافية مباشرة بـين المشرف

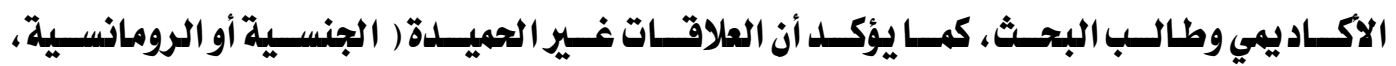
العدائية. ..إلخ ) بين المشرف وطلابه ليست مناسبة، لأز هذا تضارب واضح في المصالح، كما تسهم المبادئ التي يتضـمنها القـانون في تنظيه وتقنين المواقف والسلوكيات ليس فقط لأولئك الـذين يشـاركون في

العلاقة الإثـرافية، أيضًا تعـزز مسؤوليات الجامعـات في الحفـاظعلى بيئـة بحثيـة آمنـة وداعمة. (National Health and Medical Research Council, the Australian Research Council and Universities, Australia(2018) كما أرست سياسة الإشراف على طلاب اللدرجات العليا بجامعة نيو سوث ويلز مجموعة من المبادئ والأسس التي تنظم العلاقة الإثرافية بـين المشرف والباحث من خلال الثشـاركة الاستبـاقية في تكوين وتنمية علاقة إيجابية ومهنية تقوم على الاحترام المتبـادل بينهما، وذلك عن طريق :-Pro-Vice) Chancellor ,Research Training, Version: 4, 2016, 1-3) أن يكون للمرشحين دور رئيس في تحديد فريق الإثراف قبل تقديم طلب القبول الرسمي، وأثناء الترشيح إذا وُجدت حاجة إلى التفيير في الإشراف؛ من أجل إحداث توافق وانسجام بين الطرفين. توضيح المثرفين والمرشحين لتوقماتهم المتبادلة حول ممارسات الإثراف وحلدود العلاقة الإثرافية في بلداية الترشيح والبحث، لا سييما تلك المتعلقة بـالحفاظ على اتصالات واضحة ومنتظمة، وتحليل مواعيد الاجتماعات وإعدادها، ووضع الخطط ومواعيد الإنجاز، وأخلاقيات هذه

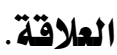

\section{$\varepsilon \leqslant 0$}

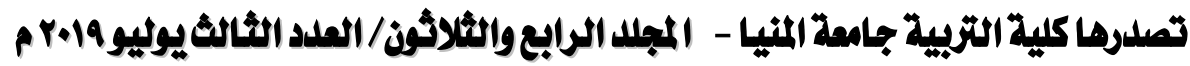
gamel_abdo59@yahoo.com

http://ms.minia.edu.eg/edu/journal.aspx 


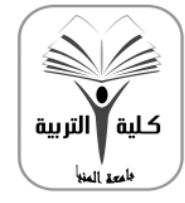

\section{مجالة البجث في التزبية وملم النفس

$$
\text { كاية التزبية - جامعة المنيا }
$$

كلية مُنتملة من الميئة القومية لضمان جودة التمليم

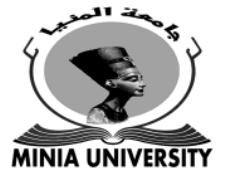

يجب على المشرفين وملارس الدراسات العليا والكليات العمل معا لتوفير استمرارية الإثراف، وفي الحالات التي يكوز فيها حاجة ماسة لتفيير الإثراف يجب أن يتم التوافق مع المرشح للوصول إلى الإشراف البليل والمناسب. تواصل المرشحين والمشرفين بشكل استباقي مع السياسات والجهات الجامعية من أجل حل النزاع والاختلاف في الآراء ووجهات النظر - إن حدث ذلك- في ظل علاقة من الاحترام المتبادل. يشارك المشرفوز والمرشحوز كأعضاء أساسيين في مجتمع الأبحاث في تطوير وتعزيز ثقافة داعمة للتواصل والتوجيه والتنمية البحثية والأخلاقية المستمرة. أن يكوز المشرفوز والمرشحون بحاجة إلى تكوين علاقة واعية قائمة على الاحترام في ظل الاختلاف الثقافي والعلمي بينهما. ينبفي للمشرفيز والمرشحين أن يضعوا في اعتبارهم إدارة تضارب المصالح في مجالات كالتأليف والملكية الفكرية، بحيث تكوز إدارة واعية لاستخدام علاقة السلطة والقوة بين المشرفين والمرشحين.

الالتزام بممارسات بحثية وإشرافية وفقا للمبادئ الأساسية للبحوث وسياسة التميز والسلامة البحثية بـالجامعة. فهم المعايير الوطنية وسياسة الجامعة والامتثال لها من قبل المشرفين والمرشحين، والسعي بشكل استباقي للمشورة المتخصصة عند الضرورة أو حلدوث مشكلات. التوافق حول المرافق والموارد المناسبة المتوفرة للدم البحث المقترح؛ حتى لا تكوز سببًا في التأخير وتوتر العلاقة الإثرافية. وضع آليات للتوافق بين المشرفين والمرشحين في نشر البحوث وأوراق العمل المشتركة أو نشر نتائج البحوث. معاملة المرشحين من قبل المشرفيز كباحثين مستقلين قادرين على إنتاج بحوث أصيلة، فهناك مسؤولية مشتركة للمشرفين والمرشحين للعمل لتطوير مقتزحات البحوث. يجب على المشرفيز والمرشحين العمل معًا للحفاظ على التقدم المستمر، والانتراط في عملية مراجعة

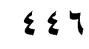

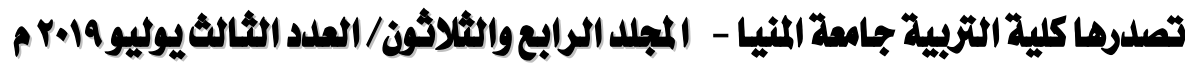
gamel_abdo59@yahoo.com

http://ms.minia.edu.eg/edu/journal.aspx 


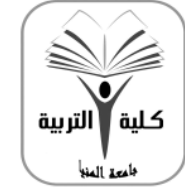

$$
\text { مجلة البعث في التربية وعلم النفس التربية - جامعة المنيا }
$$

كلية مُعتمدة من الهيئة القومية لشمان جودةالتعليم

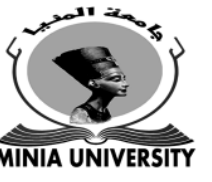

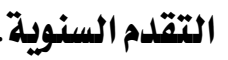

يجب أن يلعم الشرفون المرثحين في إعلاد أطروحة قابلة للفحص وتقديم المشورة للمرشح لمعالجة ردود الفعل من الفاحصين والمناقشين.

ولضمان علاقة إشرافية ناجحة ومستقرة يجب أن يضع الشرفون إطـاراً واضحًا لتلك العلاقة وإدارة الشروع البحثي ويتم الاتفاق عليه عند بلدء البحث، وهذا ينطوي على فهم توقعات المرشح، وطرق العمل \لبتوقعات الجامعة والشرف، وتلك التوقعات الإثرافية المتبادلة لجميع الأطرافي ينبفي أن تكون واضحة ومحددة، فنجاح الإشراف يعتمد بصورة كبيرة على أساليب العمل والنهج المتبع لإجراء البحوث،

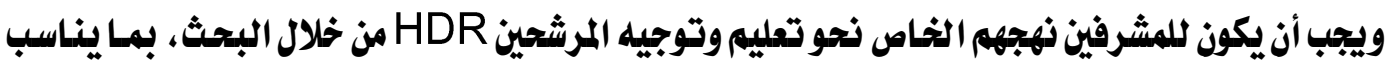
طبيعة وقدرات كل مرشح، كما ينبفي تقديم مجموعة متنوعة من الخبرات والتوقعات والالتزامات تناسب

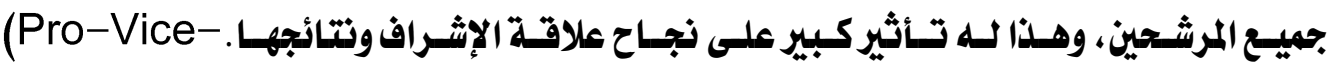
Chancellor ,Research Training, Version: 1, 2018, 3) كما أن العلاقة الإثرافية الفعالة تنطوي على الممارسات الجيدة، وتقديم الششورة المفيدة في الوقت المناسب، ومعالجة التحليات والثكلات التي تواجه الباحث، وينبفي أذيقر المثرفون ويستجيبون

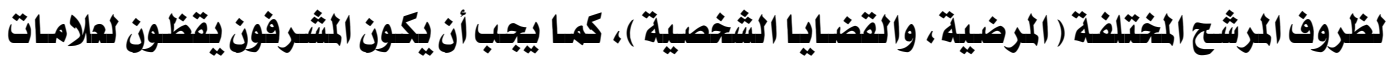

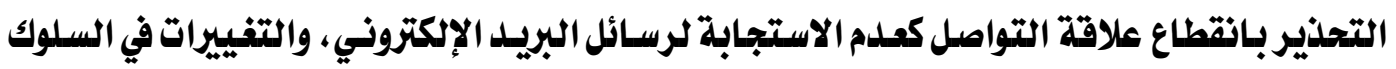
مثل : عروض العدوان أو العاطفة، والاجتماعـات التي لم يـم حضورها وتبريـر علدم الحضور، أو علدم

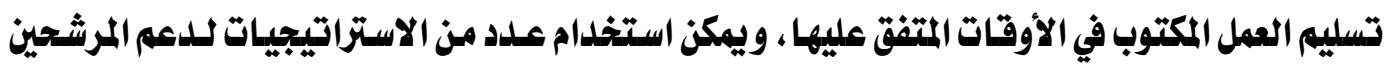
الليز يواجهوز صعوبات بحثية منها : مراجعة العقبات التي تعترض التقدم المستمر مع المرشح ، والنظر في مئي

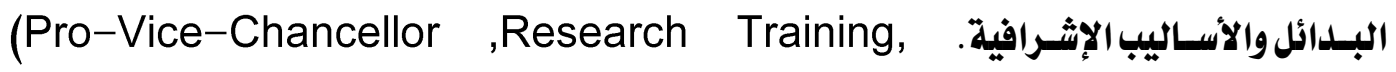
Version: 1, 2018, 3) وتأكيلًا لإقامة لعالاقة إشرافية مستقرة ومُرضية لطرفي الإشراف، وضعت جامعة نيو سوث ويلز

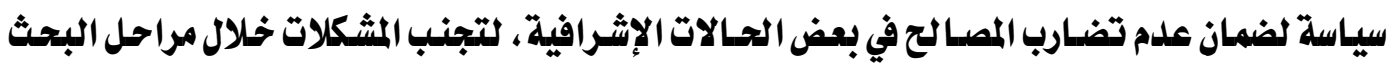

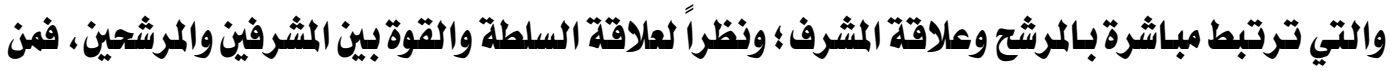
$\leqslant \leqslant \vee$

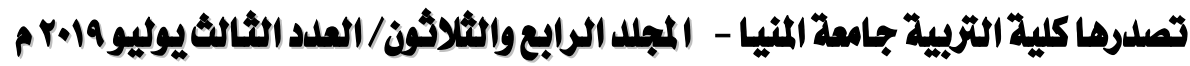
gamel_abdo59@yahoo.com

http://ms.minia.edu.eg/edu/journal.aspx 


\section{مجالة البجث في التزبية ومام النفس \\ كايلة التزبية - جامعة المثيا}

كالية مُتملةةمن الميية القومية لضمان جودة التمليم

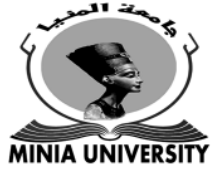

المهم ألا يتعارض المشرفوز في اتخاذ القراربشأن المشورة التي يقدمونها، وعندما يكوز المشرف مسؤولًا عن تضـارب المصـالح يجب الإعلاز عنه لملدير الملدرسة أو شخص للديـه السلطة المناسبة في UNSW، وفقًا لسياسة علدم تتضارب المصالح يتعيز على المشرفين الإعلان عن أي تضارب محتمل في المصالح مع الباحث، (UNSW, Conflict of وتقديث المشورة إلى المرشـحين للحصول على دعم مناسب عند الضرورة. Interest Policy, 2017)

وعليه ، يتضح أهمية وجود علاقة إشرافية ناجحة بـين طرفي الإثراف الأستاذ والباحث قائمة على مبادئ وأسس علمية وأخلاقية وإنسانية تسهم في استمرار عملية البحث، وتصنع جـوا مريحًا وبيئة بحثية محفزة ومشجعة لإنهاء البحث في الوقت المحلد وعلى الوجه المنشود. - - التنمية المهنية لأعضاء هيئة التلدريس في مجال الإشراف العلمي: تهتم جامعة نيو سوث ويلز بـالتنمية المهنية للمشرفين بفئساتهم المختلفة، وتعمل على تتلديم

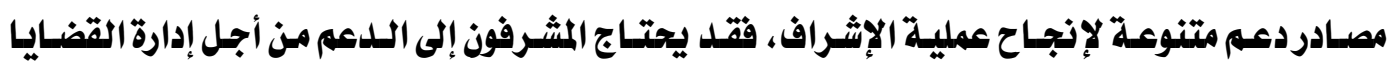
والشكلات التي قد تنشأ في نقاط مختلفة خلال الإشراف ومراحل البحث، ويمكن للمشرفين طلب الدعم والششورة من الأشخاص والجهات الآتية: , Research Training , Pro-Vice-Chancellor ,

Version: 2, 2018, 5)

$$
\begin{aligned}
& \text { - - منسق الدراسات العليا في المدارس. } \\
& \text { - مل ملير أبحاث الدراسات العليا. } \\
& \text { - الزملاء المشرفين أو الموجهين. }
\end{aligned}
$$

- عميد الكلية المساعل ( للتدريب على البحوث ) أو ما يعادله. - وحلدة خدمات الاستشارات الإثرافية النفسية (CAPS ) .

- برنامج علاقتات الموظفيز (EAP)، واللدي يقلم المشورة السرية ونصيحة للموظفين مجانًا، وقد تحدث الاستشارة عبر الهاتف أو مع شخص في مكان خارج الحرم الجامعي. وتعمل مصادر دعم المشرفين في جامعة نيو سوث يلز وتنميتهم مهنيًا ورفع كفائة أدائهم الإثرافي مئي 


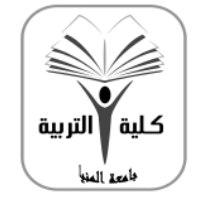

$$
\text { كجالة البحث في التزبية وملم النفسل }
$$

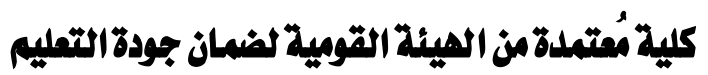

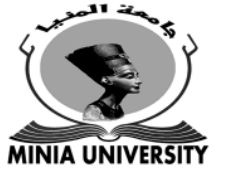

من خلال الأساليب الآتية: :Research Training, Version (Pro-Vhancellor ,Re-Chan

1, 2018, 2-5)

- تقديم خدمات اللدعم واللدورات التدريبية وورش العمل في UNSW. - - تقديم المساعدة للمشرفين في الحالات المعقدة والشكاوى المحتملة لتنمية المهارات المهنية في إدارة التعقيدات والمشكلات التي قد تنشأ من خلال الإثراف وفي مراحل البحث المختلفة. - التوجيه النصي واللدمم من منسق أبحاث اللدراسات العليا، ومساعدة عميد البحث والتدريب أو ملير بحوث اللدراسات العليا أو ملير أبحاث الخريجيز للمشرفين حول كيفية التحفيز والتوجيه في حالات المرشحين المختلفة. - تقديم خدمات الاستشارات النفسية (CAPS) للمشرفين والمرشحين، ويمن للمشرفين الوصول إلى CAPS للحصول على الدعم والموارد.

- توفير مجموعة من موارد الصحة العقلية "CAPS" وورش العمل التي تستهدف الموظفين لتطوير المهارات في تحليد متى يكون الطالب في محنة أو في خطر، ويمكن متابعة تلك الورش تهر من خلال الموقع الإلكتزوني للمجموعة، كما يمكن تفقد موعد عقل ورش العمل والتدريب على الإشراف البحثي. - يمكن للمشرفين الوصول إلى برنامج مساعدة الموظف (EAP ) المقلم من خلال إدارة الموارد البشرية، وهو عبارة عن خدمة سرية للتوجيه والاستشارة في مجال الإشراف، التي يمكن أن تساعد في القضايا ذات الصلة بـالعمل أو الشخصية للمشرفين والموظفين والمرشحين من الباحثين بجامعة نيو سوث ويلز. - تقوم الجامعة بعقد دورات تلدريبية وورش عمل وجها لوجه أو عبر الإنترنت للتدريب على النزاهة البحثية وأخلاقيات البحث العلمي للمشرفين والباحثين، ويجب على المشرفين التماس التوجيهات المتعقة بتوضيح سياسة النزاهة البحثية من جهات الاتصال الرئيسة المثار إليها سابقًا، ثم تقديم أفضل مشورة ودعم ممكنين للمرشحين فيما يتعلق بسلوكهم خلال مشروع البحث. 
- يتم تدريب المشرفين والباحثين بالجامعة عبر الإنترنت في مجال السلامة والصحة للبحوث وخاصة التي تتضمن جانبًا ميدانيًا تجريبيًا على البشر أو غيرهم من مكونات البيئة، وتلك التدريبات من الشروط الرئيسة للمشرفين ومرشحي HDR، حيث يعد ذلك ضروريًا، وضمن جوانب مسؤوليات وأدواركل منها خلال عملية الإثراف ومراحل البحث المختلفة. وباستقراء مصادر الدعم وأساليب التنمية المهنية للمشرفين على طلاب اللدرجات العليا بجامعة نيو سوث ويلز من تصميه مواقع إلكترونية وعقد دورات تدريبيـة وحلقـات دراسية وورش عمل وغيرهـا من

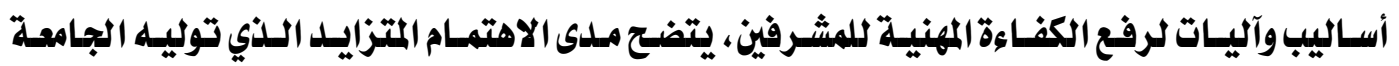
بالتنمية المهنية لأعضاء هيئة التدريس بصفة عامة، ومدى اهتمامها بالتنمية المهنية في مجال الإثراف العلمي بصفة خاصة. ثالثًا : الإشراف العلمي بجامعة أوكلاند بنيوزيلندا: تُعد الجامعات النيوزيلندية حالة فريدة عالمياً ؛ حيث إن نيوزيلندا اللدولة الوحيلدة في العـالم التي تلدخل كل جامعاتهـا في التصنيف العـالمي لأفضل خمسمائة جامعة، فالجامعـات النيوزيلنديـة الثمانية تتبـادل المراكز المتقدمة ضمن أفضل جامعات العـالم، وتعلد جامعة أوكلاند Auckland University تأسست عام بAAام، وتحتل دائهًا مراتب متقدمة في التصنيفات العالمية للجامعات، والجامعة تتكوذ من ثمـاني كليـات هي (الآداب، والتجـارة والأعمال، والصناعات والفنـوز الإبلداعيـة، والتزبيـة والتعليه، والهندسة، والقانوز، والعلوم الصحية والطبية، والعلوم واللاهـوت )، ولهـا أكثر من سبعة فروع، وهي

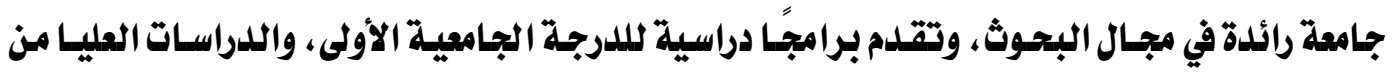
خلال كلياتها الثمان. ( الموسوعة الحرة ويكبيديا ، 19.r ).

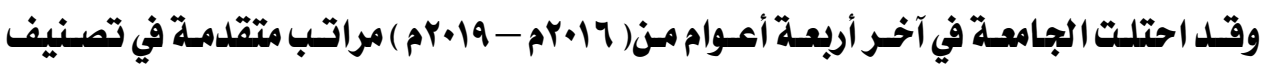

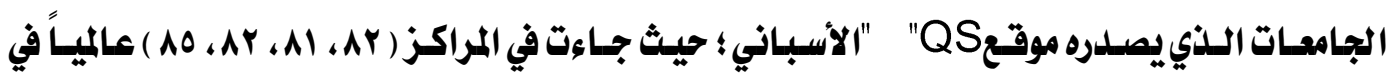
(World University Rankings, "QS" Rankings, الأعمام الأربعة على التوالي. $\leqslant 0$. 


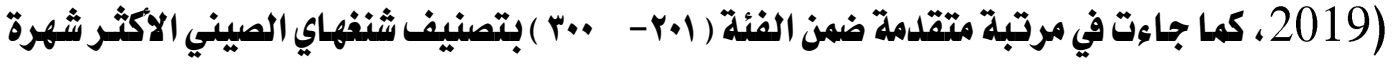

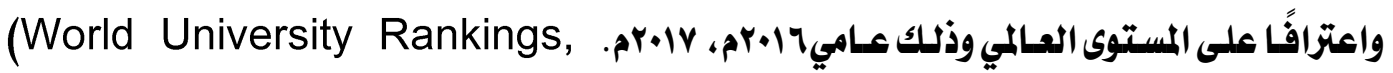
Shanghai Ranking, 2017) و وتحتفظ الجامعة بمكانتها كأفضل جامعة في نيوزيلندا. ومنذ تأسيسها في عام 1AATم، تقدمت جامعة أوكلاندل لتصبح جامعة نيوزيلندا الرائدة التي تقودها البحوث والتميز التدربسي والبحثي، وتتنوع برامجها البحثية في جحميع التخصصسات، وتقلدم خدماتها للمجتمعات المحلية والوطنية واللدولية، فلديها أكثر من ( •؛ ) ألف طالب، منهم ( •..11 ) طالب باللدراسـات العليـا و( •.•7 ) طالب دولي، ويشـارك الطلاب في البحـوث الأساسية والتطبيقيـة، ولـدى الجامعة أكثر من ( •0 ) مركزًا للتميز البحثي، بـالإضـافة للوحدات البحثية ومراكز ومعاهـد البحوث في (Auckland University, 2019)(الإدارات والكليات والأقسام العلمية. وتتمثل رؤية الجامعة في أنها تسعى لتكون جامعة بحثية عالمية معترف بها تقودهـا الأبحاث؛ للتميـز في التـدريس والـتملم والبحث العلمي والعمل الإبـداعي والإدارة، ولأهميـة إسهـاماتها في تقـلم

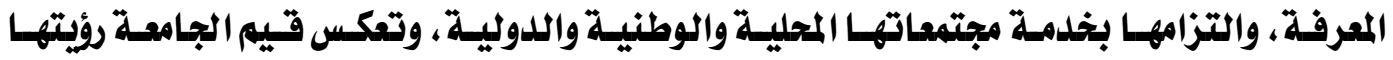
المستقبلية من حيث الالتزام بـالحفاظ على المعرفة ونشرها من خلال التعليم والتعلم والبحث العلمي والعمل الإبـداعي على أعلى مستوى، لـوإقامة مجتمع علمي متنـوع يحظى فيـه الأفراد بـالتقدير والاحسترام، ويمارس الحريـة الاكاد يميـة الفكريـة في ضوي معايير أخلاقية، كما تشرك الجامعة العلمـاء والبـاحثين الـوطنييز والــلوليين في المؤسسـات التعليميـة والبحثيـة لتعزيـز التنميـة الفكريـة والجـودة التعليميـة والإنتاجيـة البحثيـة، وتطويروتسيويق المشروعات البحثيـة والأعمـال الإبـاعيـة، وتوفر إدارة عاليـة الجـودة تتميـز بـالسياسـات والممارسـات والخـلمات الاككاد يميـة والإداريـة المفتوحسة في ضـويء الشـفافية

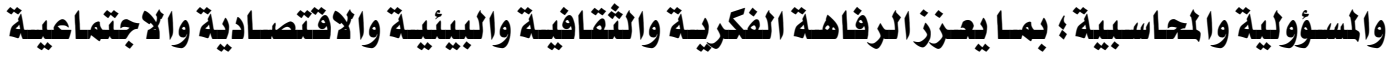
(Auckland University, Mission and Values, لمواطنين أوكلاند وشعب نيوزيلندا بـكمله

مما سبق، يتضح اهتمام الجامعة المتزايلد بـالبحث العلمي وخاصة على مستوى الدراسـات العليـا $\varepsilon 01$ 
من رسائل وأطروحات علمية في مرحلتي الماجستير والـدكتوراه، ومن ثم كـان الاهتمـام بـالإشراف العلمي على تلك الرسائل والأطروحات العلمية، ويمكن استعراض نظام الإثراف العلمي على طلاب اللدراسـات العليا بجامعة أوكلاند النيوزيلندية من خلال محاور بالبحث المختارة للمقارنة، على النحو الآتي: ا- إدارةوتنظبيم الإشراف العلمي:

Auckland تتخذ إدارة وتنظيم الإثراف العلمي على طلاب الدراسات العليا في جامعة أوكلاند نهجًا منظهًا وداعمًا للمشرفين والباحثين، حيثيثم يتم مراجعة نظام الإشراف بصفة مستمرة لضمان الجمودة في العملية الإثرافية، وذلك من خلال إدارة اللدراسـات العليـا بـالجامعة، ومركز Centre for Learning and الدراسـات العليـا، ومركز التعلم والبحث في التعليم العـالي Research in Higher Education (CLeaR) الخاصة بـالإثراف العلمي وترشيح الطاب متاحة بشكل معلن على موقع مركز الدراسـات العليـا، ومؤطرة

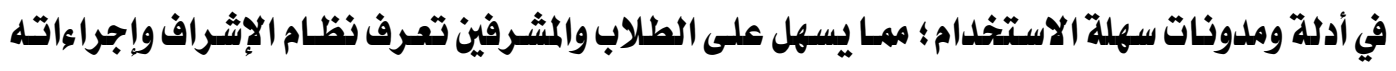
وممارساته وقواعلده وضوابطه الحاكمة. (Carton, 2018:5) ويتمثل دور إدارة الدراسات العليا في دعم وتتظييم الإثراف على البحوث كونها الميسر والدليل لخطـوات الإثـراف وإجراءاتـه ، فمجلس الدراسـات العليـا يُعـين جميـع المشـرفين على مرثـحي الماجستير الدكتوراه، ومن خلاله يتم توفير التقارير اللازمة لبيانات الطلاب والمشرفين، ومناقشّة تلك البيانات ووضمها في السياق الصحيح، ويتم تحلديث هذه البيانات كل ستة أشهر ، كما يقوم مكتب الإثراف على الدراسات العليا Graduated Supervision (GS بإصدار تقرير سنوي يضم بيانات المشرفين والطالاب، ويحتفظ مكتب التخطيط بـالجامعة ببيانات عن الشرفين المسجليز ضمن الموارد البشرية للجامعة ممن يحملوز عقود البحوث كمشرفين، والمكتب للديه حق الوصول إلى البيانات وتحليث المعلومات لاستيفاء

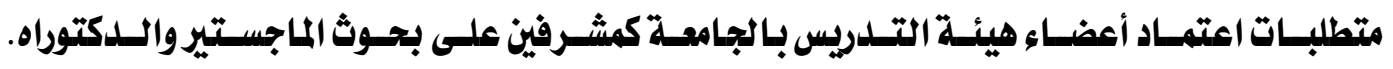
.(Carton, 2018:6) وتتظيمًا للإثراف على طلاب الدكتوراه بجامعة أوكلاند يجتمع رئيس الجامعة مع عمداء الكليات 
اجتماعًا دوريًا سنويـا لمنـاقشة مسائل ومشكلات الطلاب فيمـا يخص الإثراف، ويتم تشجيع بحميع طلاب الدكتوراه والمشرفين لاستكمال استبيانات مستوى الرضا عن الإثراف عند تقديم الأطروحات للمناقشة، وتسهل هذه العملية قياس مستوى الرضا عن جودة الإثراف العلمي، وتقلديم فحص دقيق لعلاقة الطالب والشرف وإدراك الطالب لمستوى تجربته الإشرافية. (6arton, 2018). كما يضع مجلس الدراسات العليا بـالجامعة سياسـات وإرثـادات توجيهية على مستوى الجامعة؛ لتحديل العبء الإثرافي توصي بـألا يقوم مشرفو البحوث عـادة بـالإثراف على أكثر من ( 1 ) طلاب بحث متفرغين في وقت واحل، ويتم احتساب نصاب وحمل الإثراف بنظـام النقـاط أو السـاعات المعتملدة، ويتم توزيع الأحمال الإثرافية بشكل عـادل ومناسب بين المشرفين والثـرفين المشاركين والمستشـارين المينين لفريـق الإثـراف، حيـث يشـارك معظم الاكساد يميين في الإثـراف على بحـوث الطلاب، ويجب أن تتـوازن مسؤولية الإثراف مع الالتزامات الأخرى لأعضاء هيئة التدريس المشرفين من تدريس وبحث علمي فضلًا عن خدمتهم للمجتمع الجامعي والمحلي ومسؤوليات الإدارة، بحيث يكون الحمل الإشرافي أقل لأعضاء هيئة التدريس الأقل خبرة؛ فعلى سبيل المثال : المحاضر الحاصل على دكتوراه عـادة حمله الإثـرافي أقل من ب

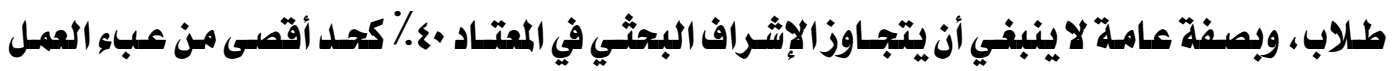
الجسامعي لعضو هيئة التدريس. The University of Auckland, Graduate Centre)

(Carton, 2018:8) 2018:3)

وتضع سياسات الإثراف العلمي بـالجامعة إجراءات وقواعد لغيـاب وإجـازات المشرفين والطلاب،

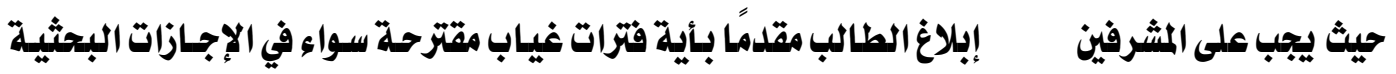
أو الدراسية أو أية إجازة مطولة تزيلد ملتها عن ( ) أسـابيع ؛ ليتم ترتيب وإسناد مهام الإثراف المؤقت إلى أعضـاء آخرين، أو تقـليم تفاصيل الاتصـال للبـاحث؛ ليتسنى لـه الحفـاظعلى التواصل الإثـرافي وتلقي السعم والتوجيه، أمـا بـالنسبة لإجـازات للطلاب فيتم التفـاوض على توقيت فترات الإجـازة مع الشرفين، وتقديم الأعدار لمشرفيهم حال الفياب لظروف طارئة كالمرض أو الالتزامات العائلية أو غيرها، وتحقيقًا لجودة الإشراف تقوم الجامعة بتقلديم اعتراف وجائزة للتميز الإشرافي على طلاب الدكتوراه، كما

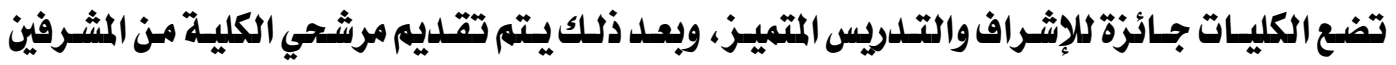
sor

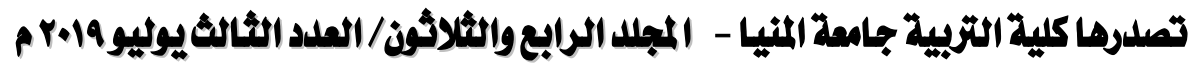
gamel_abdo59@yahoo.com

http://ms.minia.edu.eg/edu/journal.aspx 


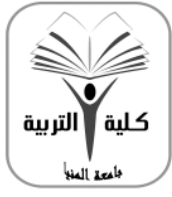

\author{
مجالة البجث في التزبية ومام النفس \\ كلية التزبية - جامعة المنيا
}

كالية مُشتملدةمن الميئة القوميل لضمان جودةالتمليم

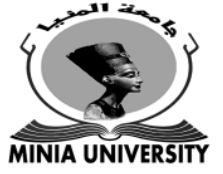

للحصول على جوائز للتميز على مستوى الجامعة ، وأولئك الـذين ينجحون في المستوى الجـامعي يتقدموز للحصول على جوائز على المستوى الوطني والعالمي أحيانًا. (Carton, 2018:9) وعليه ، تتضح جودة عملية إدارة وتتظيه عملية الإشراف العلمي بجامعة أوكلاند من أجل التميز، حيث العمل على تحليد سياسـات التعيين والاعتمـاد للمشرفين، وآليـات تحليـد العبـ الإثـرافي في ضوي إلتزامات أعضاء هيئة التدريس الإدارية والبحثية والتدريسية، وتنظيه إجازات التفرغ البحثي والفياب للهشرفين والطلاب بما لايحرم الطالب من اللدم والمساندة الإشرافية، ويسهم في استمرار جـودة الإثراف العلمي لإنجاز رسالة علمية متميزة.

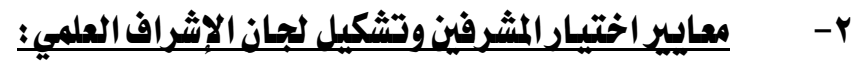

تنص وثيقة سياسة وإجراءات الإثراف العلمي بجامعة أوكلاند، والتي يتم دعمها من خلال وثيقة إرشادات الإثراف على اللدراسات العليا على أنه يجب أن يكوز للى جميـع الطلاب إمـا مشرف رئيس معتمد أو مشرف مشارك أو مشرفان مشتركان أو مستشار أو لجنة استشارية للإثراف على الأطروحة، ويتم تعيين فريق أو لجنـة الإثراف من قبل مجلس اللدراسـات العليـا، ويجب على جميع المرشتحين للماجستير والدكتوراه الحصول على مشرف معتمـل، وفي بعض التخصصسات وقدل يكوز للطلاب أيضًا مشرفًا مشـاركًا، (The University of وهنكاك مجموعة من المعـايير لاختيـاروتشكيل لجسان الإثراف، منهـا:

Auckland, Graduate Centre, 2018:4)

- - يجب أن يكوز جميع المشرفيز حاصلين على درجة الدكتوراه، ومؤهلين للإشراف بشكل مناسب. - أن يكوز للمشرف إنتاج بجثي في مجال التخصص العام واللدقيق لبحث للطالب. - أن يكوز المشرف الرئيس موظفًا في الجامعة ومشرفًا معتمدًا. - - مي حالة الإشراف المشترك يكوز أحد المشرفين على الأقل موظفًا في الجامعة ومشرفًا معتمدًا. - يتحمل المشرف الرئيس المسؤولية الكاملة عن الإثراف وعن المساعدة في توفير موارد البحث، وفي حالة الإثراف المثترك يتقاسم المشرفان المسؤولية عن البحث والباحث. - - لا يجوز تعيين المشرفين المحتملين اللذين هم أنفسهم مرشحوز للدكتوراه إلا للنصيحة والاستشارة. وهناك مجموعة أخرى من المعايير لاختيار المشرفيز على الرسائل العلمية بجامعة أوكلانل، وهي : \&०

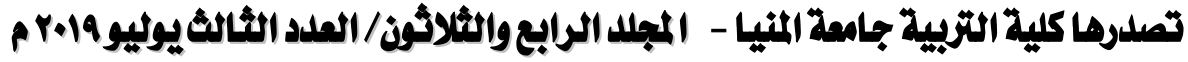
gamel_abdo59@yahoo.com

http://ms.minia.edu.eg/edu/journal.aspx 


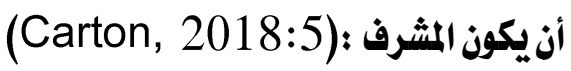

- - - أحل أعضاء فريق العمل بجامعة أوكلاند.

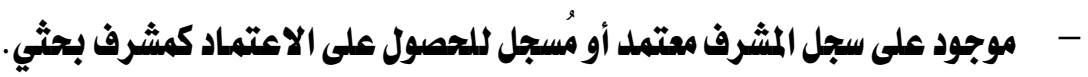

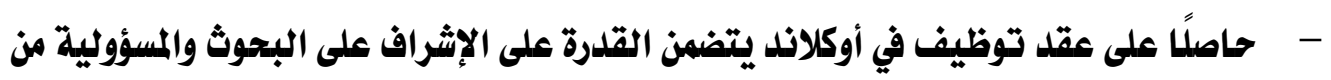
أجل العمل كمشرف رئيس. - - أشرف على مرشح للدكتوراه حتى الاتتهاء على مستوى الإثراف الشترك في UoA أو كمشرف رئيس في مؤسسة بحثية أو جامعة أخرى. - شارك في ندوة سياسة وتوجيهات برنامج التعليم من أجل الدكتوراه، والتي تتناول السياسات واللوائح والممارسات التتعلقة بالإشراف على البحوث. - - حضر ندوة إحاطة الدكتوراه حول سياسات وإجراءات UOA في الإشراف على البحوث والتي تعقد كل خمس سنوات. - -

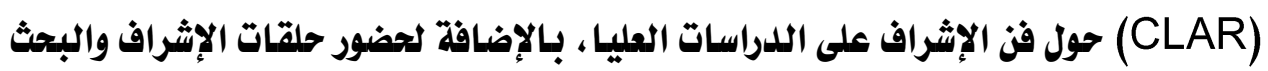

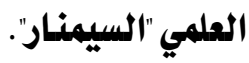
يتضح مما سبق أن لجامعة أوكلاند معايير متميزة لاختيسار المشرفين على الرسائل والأطروحسات

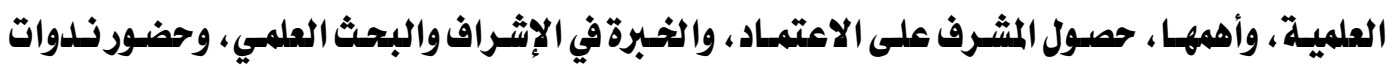

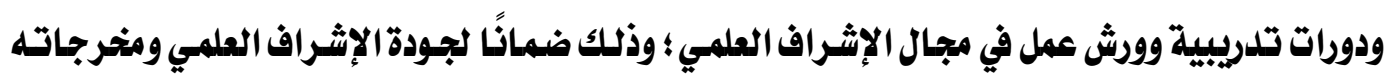

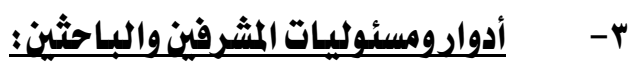
توفر وثيقة إرشادات الإثراف على الدراسـات العليـا إجراءات ومعلومـات حول مـا هو متوقيع من

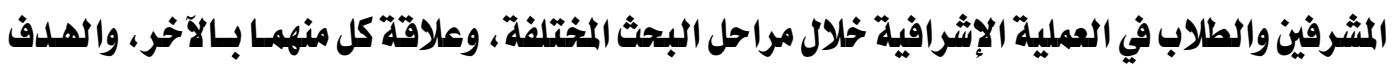

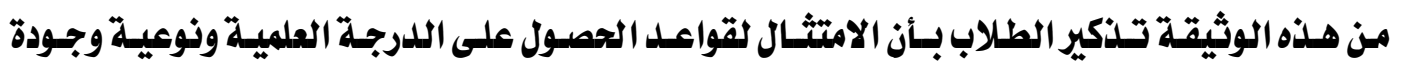

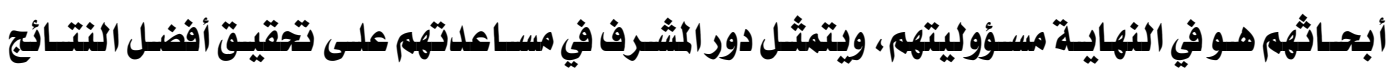
- $\& 00$

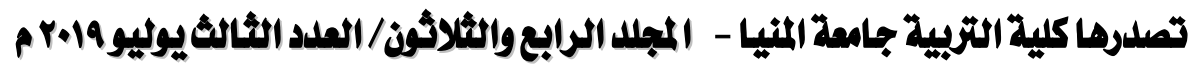
gamel_abdo59@yahoo.com

http://ms.minia.edu.eg/edu/journal.aspx 
والمخرجات البحثية في ضوي علاقة إثرافية تعاونية لضمان مخرج بحثي متميز، وتحلد هـذه الوثيتة (The University of أدوارومسئوليات الفئسات المختلفـة من المشرفين، على النحسوالآتي : Auckland, Graduate Centre, 2018:4-5) - - المشرف الرئيسي: يجب أن يكون موظفًا في الجامعة، ويتحمل المسؤولية الأساسية عن توفير المشورة واللدعم الاكاد يمي والمتطلبات الإدارية المرتبطة بـالبحث. - المشرفوز المشتكوز: يتحملون المسؤولية المثتركة عن توفير المشورة والدعم الاكاديمي للطالب، لـويجب أن يتحمل أحد المشرفين المشتركين المسؤولية الأساسية عن المتطلبات الإدارية

$$
\text { المرتبطة بمشروع البحث. }
$$

المشرف المشارك: هو مشرف استباقي في تقديم المشورة واللدم الاكاديمي، عادة يكوز عضواً في فريق عمل جامعة أوكلانل ( وفي هلذه الحالة يمكن اشتراكه بلدًا من المشرف الرئيس في حالة غيابه ) لتقديم اللدمم والتوجيه والمساندة في مراحل البحث المختلفة. - مستشار القسه: يخصص للمرشحين لنيل درجة الدكتوراه فقط؛ لتقديم المشورة والدعم عند

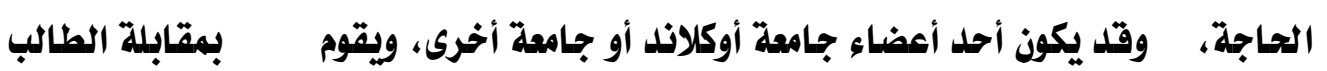
مرة واحدة في السنة على الأقل لمراجمة التقدم البحثي وتقديم التوجيه واللدم بشأز مشروع البحث. وتتنوع أدوارومسئوليات المشرف والطالب كعلاقة عمل تعاونية في كل مرحلة من مراحل البحث ؛

على النحو الآتي(The University of Auckland, Graduate Centre, 2016) :

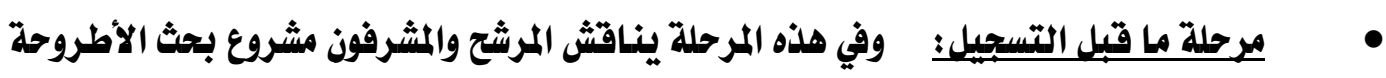
المقتزح، الموارد اللازمة لتنفيذ البحث، ومستوى توافر اللدعم من الجهات المختلفة والذي يجب أن يكوز متاحًا لإتمام البحث بنجاح، ودراسة وتوقع أية مشكلات متعلقة بـالملكية الفكرية قد تنشأ أثناء البحث، والتزامات وتوقعات كل المشرف والباحث من أجل تجنب أي سوء فهم محتمل. مرحلة بلدالية اللدراسة: وفيها يناقش المرشح والمشرف المشكلات المتعلقة بـالملكية الفكرية التي قد تنتج عن الأبحاث وحقوق النشر والتأليف لأية منشورات يمكن كتابتها بناءً على بحث $=$ ร०ฯ

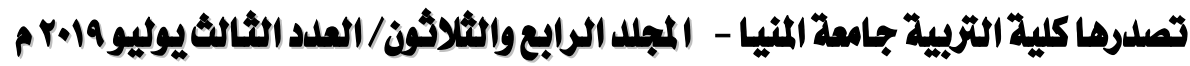
gamel_abdo59@yahoo.com

http://ms.minia.edu.eg/edu/journal.aspx 


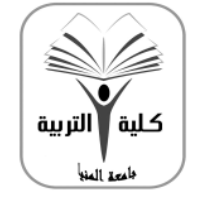

$$
\text { مجلة البجث في التزبية وملم النفس }
$$

كلية مُتملدة من الميئة القومية لضمان جودةالتمليم

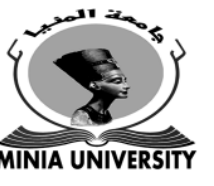

\section{الأطروحة.}

أثناء الدراسة: يتوقع من المرشح والمشرف أن يجتمعا مرة واحدة على الأقل في الشهر، ولكن في بعض النقاط البحثية أو بعض مراحل الاطروحة قد يعتاجون إلى مقابلات واجتماعات أكثر. وبصفة أكثر تحديدًا يمكن عرض أدوارومسئوليات المشرف والباحث في العملية الإثرافية خلال

$$
\text { أ- أدوارومسئوليات البشرث: المختلة، على النحو الآتي: }
$$

يمكن توضيح أدوارومسؤليات المرف خلال المراحل المختلفة للبحث، على النحو الآتي : The )

University of Auckland, Graduate Centre ,2016)

1- بليلة الإشراف: وتتمثل مسئوليات وأدوار المشرف خلالها في:

- - لفت انتباه الطالب إلى بحيي سياسات الجامعة ذات الصلة بالبحث والإشراف كالسياسات المتعلقة بإجراء البحوث، والمتطلبات الأخلاقية وحقوق الملكية الفكرية، ومتطلبات حقوق

$$
\text { التأليف والنشر. }
$$

- - تقديم إرثادات حول طبيعة البحث والمعايير المتوقعة للإنجاز، وتغطيط البحث، والأدبيات والمصادر، الموارد والمرافق البحثية، التقنيات والامكانات المطلوبة. .إلخ.

- مناقشة الطالب حول مستوى الاتصال والتواصل المطلوب خلال الاجتماعات واللقاءات الإشرافية أو البرامج التعليمية أو الحلقات الدراسية وضمان الحفاظ على هذا الاتصال بصورة

$$
\text { مستمرة. }
$$

- توجيه الطالب إلى مصادر المعلومات المناسبة حول الأمور "الإدارية والفنية" كطول الأطروحة، والأسلوب الموصى به في الكتابة والتنسيق، والتخطيط الفني للأطروحة، وعلد النسخ المطلوبة، واللوائح المتعلقة بالتمديد لفترات التسجيل، والمصادر المحتملة لتمويل البحوث. - - الاتفاق مبكراً على الأسلوب والتخطيط المتتخدم في كتابة الأطروحة وتنسيقها وشكلها. - تقديم الشورة المستمرةبشأن الجدول الزمني لإعداد الأطروحة أو المنشورات البحثية، ومناقشة الاتفاقات حول التأليف والنشر المثرك. $\varepsilon \circ V$

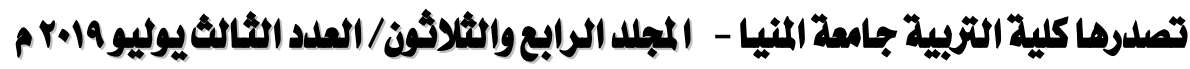
gamel_abdo59@yahoo.com

http://ms.minia.edu.eg/edu/journal.aspx 


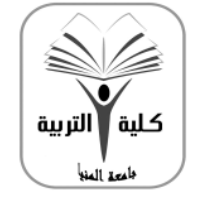

$$
\text { مجلة البعث في التزبية وعلم النفس التربية - مامعة المنيا }
$$

كلية مُشتعلة من الهيئة القومية لشمان جودة التعليم

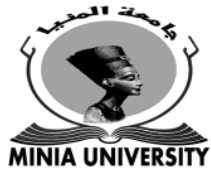

$$
\text { r - أثناء البحث: ت تتثل مسئوليات وأدوار الشرف في الآتي: }
$$

- - أن يكوذ في متناول الطالب في الأوقات الضرورية التي قدل يحتاج فيها إلى مشورته.

- - تقديم الشورة بشأن مواعيد الاتتهاء المناسبة للمراحل المتعاقبة من البحث، بحيث يمكن تقليم

$$
\text { الأطروحة كاملة في الوقتت المحدد. }
$$

- طلب العمل المكتوب من الطالب عند الضرورة وفي الموعد المحلد، وإعادة هذا العمل مع ملاحظات

$$
\text { بناءة في وقت معقول. }
$$

- ل - لفت اتتباه الطالب إلى أية دورات أو ورش عمل يتم تقديمها ، ويمكن أن تساعده في التفلب على

$$
\text { المشكلات البحثية أو الجوانب الأخرى من البحث. البهاه }
$$

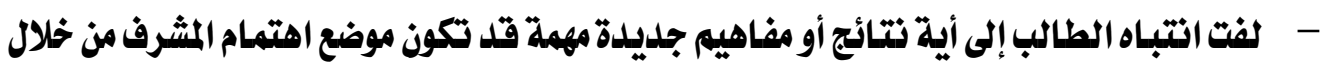
اتصالات المرف مع غيره من المشرفين المحترفين والباحثين. - ت توفير التوجيه والإرثاد في العمل الميداني حالة وجود جانب ميداني للبحث. - - توجيه الطالب لخبراء في المجال والتخصص وموضوع الأطروحة عند الضرورة، وتقليم الشورة بشأن المؤتقرات والمنظمات ذات الصلة بالتخصص وموضوع البحث. - - المراقبة والتقيييم وكتابة تقارير دورية حول مستوى تقلدم الطالب خلال مراحل البحث المختلفة. - - التأكل من إبلاغ الطالب كتابة بأية قصور في التقدم أو معايير العمل التي تقل عن المتوقع. - - الاحتفاط بسجلات مكتوبة فيما يتعلق بعمليات الإشراف والتوجيه، وخاصة أية مخاوف تم

$$
\text { إبلاغها للطالب. }
$$

- التأكلد في المراحل النهائية لإعلاد الأطروحة من أنها متاحة لقراءة المسودات الأولية، وتقديم

$$
\text { تعليقات مكتوبة سريعة وملاءمة حول تلك المسودات. }
$$

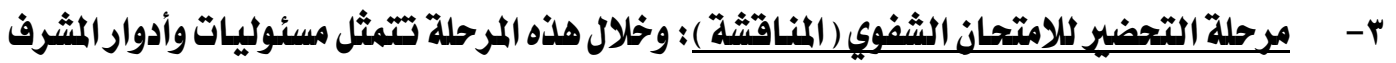

$$
\text { في الآتي: }
$$

- - مناقشة الطالب حول أعضاء لجنة المناقشة والفحص المتوقعين ومراعاة رغبته في الاختيار. - - مشاركة الطالب في الترتيب للمناقشة والفحص. «०ᄉ

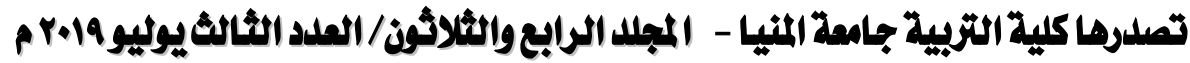
gamel_abdo59@yahoo.com

http://ms.minia.edu.eg/edu/journal.aspx 


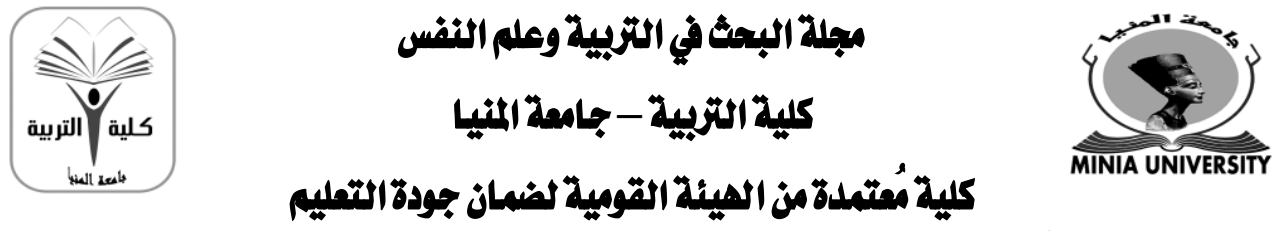

\section{- - - ممان نهج موضوعي وعادل من قبل المناقشين في مناقشة الأطروحة وفحصها.} - - مساعدة الطالب في فهم تعليقات المتحنين (المناقشين ) وكيفية تلبية متطلباتهم، والإثراف على إجراء وتنفيذ هذه التعليلات والمتطلبات. ب- أدوارومسئوليات البياهث:

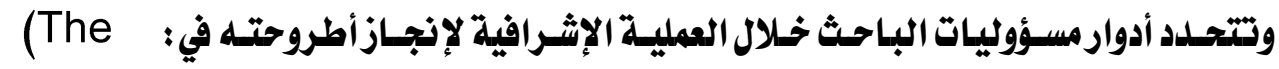
:University of Auckland, Graduate Centre, 2018:8)

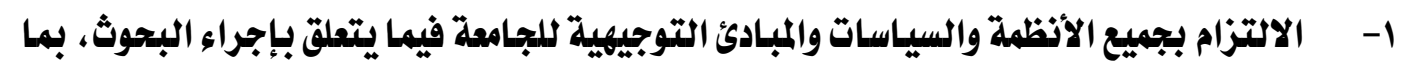

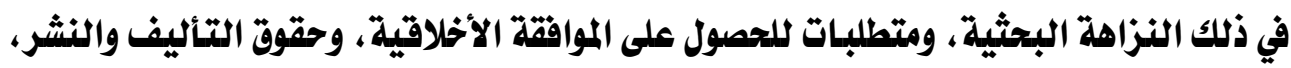
والصحة والسلامة للبحوث والعمل الميلاني....إلخ. r- الحفاظ على التواصل الواضح والمقتوح مع الشرفين، والتوافق حول جدول زمني للاجتماعات

واللقاءات الإشرافية، وحضور جميع الاجتماعات المتفق عليها والإعداد الكامل والمسبق لها. r- أخذ زمام المبادرة في تنظيم الاجتماعات الإثرافية وفقًا للجدول الزمني المتفق عليه، واتخاذ وتداول ملكرات من الاجتماعات وتطبيق ملاحظاتها. ؟- مناقشة المشرف حول الإرثادات ونوع التوجيه والتعليقات التي تكون أكثر فائدة.

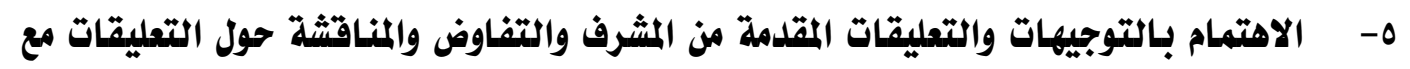
جيع الشرفين في لجنة الإشراف مع الجدية في تنفيذها. 7- تحمل المسؤلية كاملة عن بحثه كجزء من تطوير الاستقلال الفكري والبحثي.

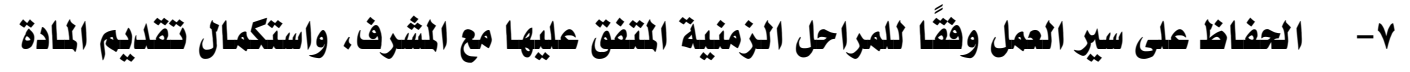
البحثية مكتوبة كما هو مطلوب في وقت مناسب للسماح للمشرف بالتعليق والمناقثة قبل الانتقال

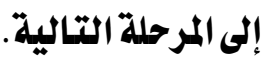
1- تنبيه المشرف إلى أية مشكلات تحدث قد تؤثر في قدرته على التقدم في البحث، وعلى العلاقة

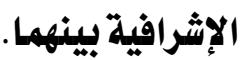
9- تقرير متى يرغب في تقليم الاطروحة، مع الأخذل بعين الاعتبار رأي المشرف أولًا، والتأكلد من $\varepsilon \bullet 9$

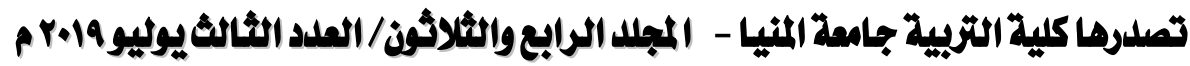
gamel_abdo59@yahoo.com

http://ms.minia.edu.eg/edu/journal.aspx 


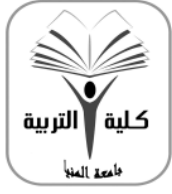

$$
\text { مجلة البعث في التربية وعلم النفس التربية - جامعة المنيا }
$$

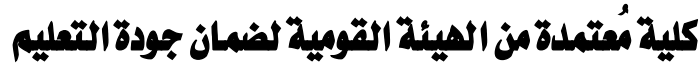

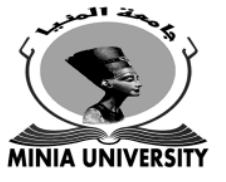

الالتزام بالمواعيد النهائية المحددة من قبل الجامعة.

•l- وعليه، تتنوع وتعدد أدوار ومسئوليات الشرفين والباحثين بجامعة أوكلاند وتوزع على الالمراحل المختلفة للبحث، ويجب قيام كل طرف بـأدواره ومسئولياته كاملة للخروج بعمل علمي متميز.

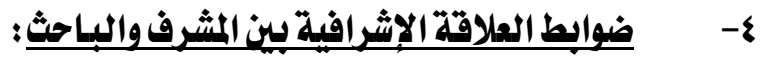

تؤسس إرشادات ومبادئ مجلس الشيوخ حول الإشراف على الرسائل العلمية الضوابط والقواعد المنظمة للعلاقة الإشرافية بين الشرف والطالب في جامعة أوكلاند؛ حيث تهلف إلى توفير التوجيه والإشراف المناسب لطلاب الأطروحات العلمية، وعلاقات المشرفين والطلاب المتقدمين للحصول على شهادات الماجستير التي لها أطروحة بحثية رئيسية ودرجات الدكتوراه التي تحتوي على عنصر البحوث الخاضعة للإثراف، ويتم تذكير الطاب بأن الامتثال للوائح وجودة البحوث هو في نهاية الطاف مسؤوليتهم الشخصية، وأن دور الشرف على البحوث هو مساعدتهم على تحقيق أفضل النتائج ؛ حيث تساعد العلاقة

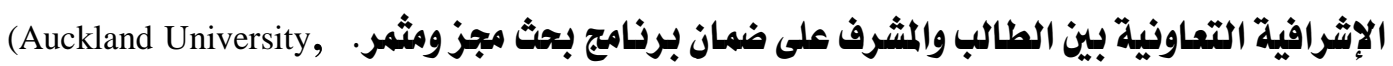

School Graduate Studies, 2014)

وتؤكل ذنك أدلة وإرثادات الجامعة حول الإشراف على الرسائل والبحوث العلمية؛ حيث تنص على توفير التوجيه والإشراف واللدم الملائم للطلاب الباحثين في مرحلتي الماجستير والدكتوراه، ودعم وتنظيم العلاقات الإشرافية بين الطلاب والشرفين لإنجاز بحوث متميزة والحصول على درجات الماجستير والدكتوراه، ويتم تذكير الطلاب بـأن الامتثال لقوانين اللدرجة العلمية وجودة العمل البحثي هو في النهاية مسؤوليتهم الأولى والأساسية. The University of Auckland, Graduate Centre, . Postgraduate Supervision Guidelines 2016:8) ويتثل دور المشرف في مساعدة الطلاب على تحقيق أفضل نتائج البحوث التي يقوموذ بها، وتساعد العلاقة الإثرافية التعاونية بين الطالب والشرف على ضمان برنامج ومشروع بحثي متميز، وفي حالة حدوث توتر في العلاقة الإشرافية بين الطالب والمشرفين عادة ما يكون اللجوء إلى رئيس القسم في

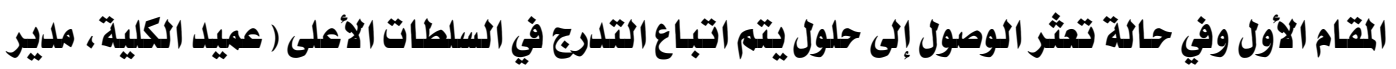

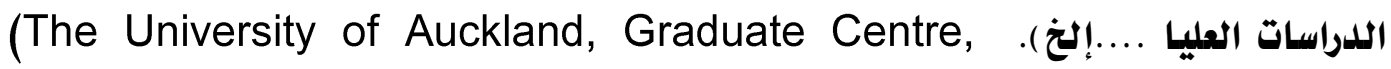

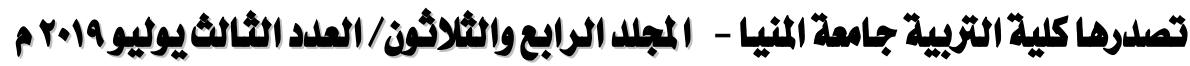
gamel_abdo59@yahoo.com

http://ms.minia.edu.eg/edu/journal.aspx 


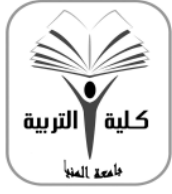

\section{مجلة البعث في التزبية وعلم النفس \\ كلية التزبية - جامعة المنيا}

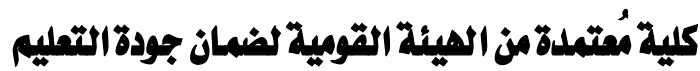

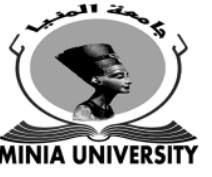

(2017:15 ، وتشجع جامعة أوكلاند الحل الفوري وغير الرسمي لجميع النزاعات الاكاديمية وغير الاكاديمية للطاب عند نشوئها وفقًا لإجراءات الشكاوى والمنازعات لحل النزاعات والشكاوي الاكاد يمية الشية ( Auckland University, Academic disputes and غير الاكاديمية. complaints, 2019)

كم يقدم موقع الجامعة وقسم الإحصاء فيما يخص الإثراف وتنظيم العلاقة الإشرافية بين الشرف والباحث بعض المعلومات المهمة للباحث من أجل علاقة إشرافية تعاونية ومهنية سليمة وناجحة، تجعل العمل مع الشرف مفتاح نجاح للباحث وتجعله يتوقع كل ما يمكن أن يحلث في إطار هذه العلاقة، من خلال طرح مجموعة من الأسئلة والإجابة عليها، وأهمها : ماذا لو واجهت صعوبـات مع المشرف؛، ما اللذي يجب أن يتوقعه المشرف مني؟، ماذا علي أن أفعل قبل مقابلتي مع المشرف؟، ماذا علي أن أفعل خلال الاجتماع مع الشرف؛، ماذا لو كنت بحاجة إلى تفييي المرفين؟، ويقلم الموقع إجابات مكتملة ومفصلة

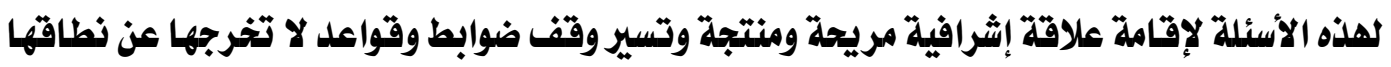
السليه.(The University of Auckland, Department of Statistics ,2019) ومما سبق، يتضح أن جامعة أوكلاند تضع مجموعة من الضوابط والقواعد التي تحكم وتتظم العلاقة الإثرافية بين المشرف والباحث من خلال إرشادات ومبادئ مجلس الشيوخ للإثراف على الرسائل، والموقع الرسمي والأدلة الخاصة بالإشراف على طلاب الدراسات العليا؛ من أجل تهيئة بيئة بحثية وإشرافية مشجعة للباحث على إنجاز أطروحته في الوقت المحلد وعلى الوجه المنشود. 0 - التنمية المهنية لأعضاء هيئة التدريس في مجال الإشراف العليمي: تدرك جامعة أوكلاند أن بعض المرفين على البحوث قد لا يكوز لديهم المهارات المطلوبة لتوجيه الطلاب وتنمية مهاراتهم البحثية بشكل فعال، ومن ثم فإن اللدم المركزي في التدريب على المهارات البحثية والإثرافية للشرفين والطلاب الباحثين هو عامل مهم، ويتم تسهيله من قبل المكتبة ومركز التعلم والبحث في التعليم العالي (CLeaR )، والنهج العام لتدريب الثشرف العلمي في جامعة أوكلاند أن التدريب شرط للاعتماد والتسجيل للإشراف على طلاب الدراسات العليا، وله تتأثير مباشر وقابل للقياس على معدلات الإنجاز والإنتاجية البحثية للمشرف والباحث، فهناك ثروة من الأدلة السردية على أن

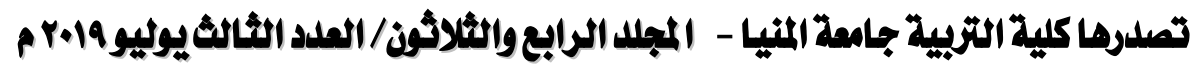
gamel_abd059@yahoo.com

http://ms.minia.edu.eg/edu/journal.aspx 


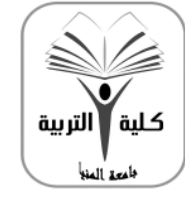

\author{
مجالة البجث في التزبية ومام النفس \\ كاية التزبية - جامعة المنيا
}

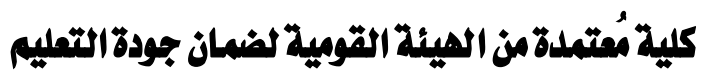

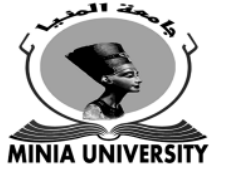

برامج التدريب التي تلعم التنمية المهنية لمثرفي البحوث يتم تقييمها بشكل مستمر من قبل الجامعة وتطلب عندما تكوز غائبة.

ويقلد مركز التعلم والبحث في التعليم العالي (CLeaR ) على وجه التحديد إرثادات حول الممارسات الإثرافية، وتسهيل برامج التدريب والتنمية المهنية لمشرفي البحوث الجدد وذوي الخبرة، كما يلعب عميد الدراسات العليا دوراً رئيساً في التخطيط والإعداد لبرامج التدريب والتنمية المهنية، والتي تضم المشرفين مع طلاب الدكتوراه من اللدوليين، حيث إن نصف علد المرشحين الجدد للحصول على درجة الدكتوراه دوليين؛ ولذلك يتم التركيز على دعم طلاب وموظفي جامعة UoA الجدد في نظام التعليم العالي في نيوزيلندا. (Carton, 2018:5)

ويمثل مركز التعلم والبحث في التعليم العالي (CLeaR ) القيادة المؤسسية المساندة للبحث العلمي في التعلم والتعليه العالي وخاصة على مستوى الدراسات العليا، وتهلف برامجه وأثطته إلى تحسين جودة التعليه والبحث العلمي في جامعة أوكلاند من خلال الترويج للممارسة الناقدة والمبتكرة ونهج البحث والإثراف العلمي، ومن وخلاله يتم اعتماد المشرفين وتتميتهم مهنيًا في ضوء برامج ودورات تدريبية وورش عمل وحلقات دراسية، وهذه الأنشطة والبرامج والحلقات اللدراسية والإثرافية مطلوبة لأعضاء هيئة التدريس الذين يرغبون في القيام بلدور إثرافي متميز، ومن الأثطة التي يقدمها المركز في مجال التنمية المهنية للمشرفيز ما يلي: (The University of Auckland, CLeaR, 2018) - - ندوة ودورة تلدريبية حول التوجه إلى سياسة وعملية الدكتوراه ( ORIDOC)؛ قبل بلدي الإشراف على طلاب اللدراسات العليا، يجب على أعضاء هيئة التدريس حضور نلدوة "التوجه نحو سياسة وعملية تعليم الدكتوراه (ORIDOC)؛ من أجل الحفاظ على الإثراف المؤهل والفعال، ويجب حضور هذه الدورة مرة واحلة كل خمس سنوات. ورشة عمل "فز الإشراف على اللدراسات العليا": حيث يجب على أعضاء هيئة التدريس الجلد والمبتلدئين في الإشراف على الرسائل والأطروحات العلمية حضور ورشة عمل CLeaR بعنوان "فز الإشراف على بحوث الدراسات العليا" ؛ حتى يتمكنوا من 
القيام بأدوارهم ومسئولياتهم الإثرافية على الوجه المنشود، وتركز هذه الورشة على الممارسات الإثرافية الصحيحة في إطار علاقة إشرافية مهنية وإنسانية واجتماعية، مشيرة إلى مصادر التوتر

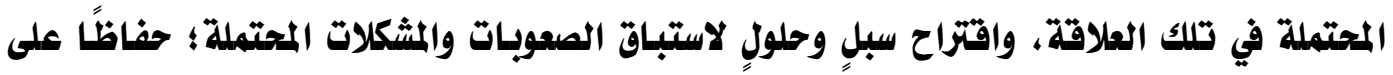
استمرارية ونجاح العلاقة الإشرافية.

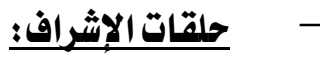

يجب على أعضاء هيئة التلديس اللئن له يشرفوا على مرشحي الدكتوراه كمشرف مشارك في الجامعة أو كشرف رئيس في جامعة أخرى حضور ورشتي ( حلقتين ) عمل إضافيتين على الأقل حول الإثراف

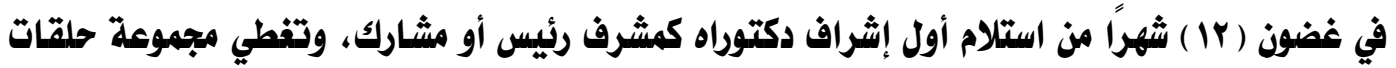

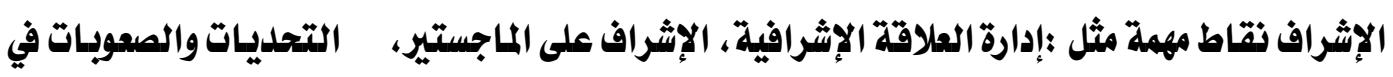

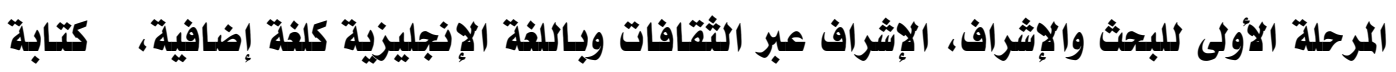
التعليقات حول محتوى الأطروحة وفصولها ...إلخ.

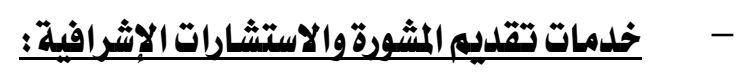
يقدم مركز CLeaR خدمة الاستشارات الإثرافية، فإذا كان المشرف يرغب في بعض التطوير المهني المحلي من قبل مستشار الدراسات العليا في القسم أو الكلية فيكن مساعدته وتقليم الثشورة لها والإجابة عن استفساراته، ويلدم المركز أعضاء هيئة التدريس من خلال تقديم اللدم والمساندة. بالإضافة لما سبق ينظم مركز CLeaR في UoA ورشتين تدريبيتين إلزاميتين لمشرفي الدكتوراه الجدد، كما يقدم المساعدة في التطوير المهني المحلي للمشرفين أو مستشاري الدراسات العليا في

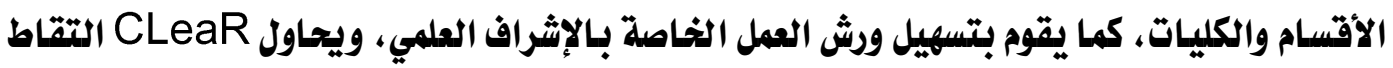
تجربة المشرف باستخدام طريقة عرض واستخلام هذه المعلومات لمراجعة وضبط الدعم والتطوير المهني. كما يوجد بجامعة أوكلاند أدوات ومصادر دعم إضافية للإشراف على بحوث الدكتوراة، أههها : :(Carton, 2018:7-8)

\section{• موقع جامعة أوكلاند للعطلومات ووثائق التوجيه حول الإشراف العلمي:} يحتوي موقع جامعة أوكلاند على علد من الامتدادات الإلكترونية لدعم الوثائق الخاصة $=$

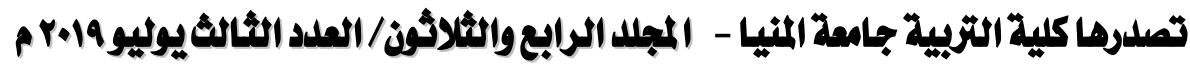
gamel_abdo59@yahoo.com

http://ms.minia.edu.eg/edu/journal.aspx 
بالإشراف العلمي، بما في ذلك السياسات والإرشادات وقواعد الممارسة والتوصيات المتعلقة بحل المشكلات في الأبحاث وقوائم المراجعة، بـالإضافة لبعض الوثائق سهلة الاستخدام المتاحة للطلاب والمشرفين، ويُعد الموقع أداة رائعة، يمكن التنقل فيها بسهولة؛ لتلقي الدعم اللني تقدمه الجامعة في مجال البحث

• دليل تطوير الإشراف على الدكتوراه:

يساعد دليل تطوير الإشراف على الدكتوراه في تسهيل المناقشة والحوار بين المشرف والطالب،

وتبادل المشورة بشأز توضيح التوقعات المتبادلة، وتقديم اللدم لتطوير علاقة إشراف تعاونية بين المشرف وطالب الدكتوراه، وتوضيح خطوات وإجراءات التقويم للمشرف على اللدكتوراه، تقويم طالب الدكتوراه.

\section{• استبيـان تجرية الإشراف على الدكتوراه :}

وهو أداة رائعة لقياس مستوى الرضا عن تجارب الإشراف على طلاب اللدكتوراه بـالنسبة للمشرف والطالب، وتقدم هذه الأداة معلومات عن المجالات التي يحتاج أعضاي هيئة التدريس والطلاب إلى الدعم والتطوير فيها لتسهل لهم الإثراف والبحث وإعادة النظر والتأمل في ممارساتهم وأدوارهم ومسئولياتهم. ومما سبق، يتضح ملى اهتمام جامعة أوكلاند بعملية التنمية المهنية للمشرفين والطلاب وأشطتها وأساليبها، من خلال اللدورات التدريبية والندوات وورش العمل وحلقات الإشراف والأدلة الإثرافية، وموقع الجامعة الإكتروني، وما يقدمه مركزCLeaR من أنشطة وأساليب للتنمية المهنية؛ وذلك إيمانًا من الجامعة وإدارتها بـأهمية الإشراف في تجويلد البحوث والرسائل العلمية. وفي ضوء العرض السابق لخبرات الجامعات الثلاث المختارة في مجال الإشراف على الرسائل العلمية بـاختلاف مسمياته ومصطلحاته في تلك الجامعات مع اتفاق مضموذه وجوهره كعملية توجيه وارشاد لباحثي الماجستير والدكتوراه لإنجاز رسائلهم وأطروحاتهم العلمية، يتضح أن الجامعات الثلاث تهتم اهتمامًا كبيرًا بـالإشراف العلمي على طلابها ورسائلهم، كما يتبين أن هناك ملامح مشتركة وأوجه شبه واختلاف بين نظام الإثراف العلمي في هذه الجامعات وبين الإثراف على الرسائل العلمية بنظيراتها المصرية، وعليه يمكن الخروج بمجموعة من اللدروس وأوجه الاستفادة يمكن الارتكاز عليها في بناء محاور

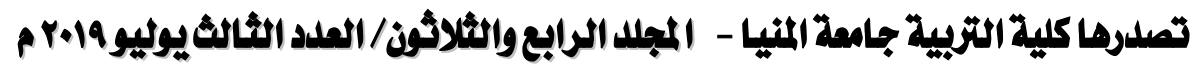
gamel_abdo59@yahoo.com

http://ms.minia.edu.eg/edu/journal.aspx 
الرؤية التطويرية المقتزحة للإشراف العلمي بـالجامعات المصرية بما يناسب طبيعة وثقافة المجتمع المصري وسياساته البحثية والتعليمية بالدراسات العليا الجامعية، وهذا ما يتناوله البحث في المحاور القادمة من تحليل مقارن لأوجه الشبه والاختلاف، واستخلاص أوجه الاستفادة من الخبرات الجامعية

الثلاث، ثم بلورة الرؤية التطويرية المقتز حة. - المحور الخامس : التحليل المقارن لأوجه الشبه والاختلاف بين الخبرات الثلاثة، وأوجه الاستفادة منهبا: يتناول هذا المحور تحليلًا مقارنًا لأوجه الشبه والاختلاف بين نظام الإشراف على الرسائل العلمية في الجامعات الثلاثة المختارة موضع المقارنة والجامعات المصرية، وذلك في ضوء محاور البحث المُشار إليها بـالحدود الموضوعية؛ لاستخلاص بعض الدروس وأوجه الاستفادة من خبرات تلك الجامعات، ومحاولة الارتكاز عليها في بناء الرؤية المقترحة لتطوير الإثراف على الرسائل العلمية بالجامعات

ومن خلال استعراض خبرات الجامعات الأجنبية الثلاثة المختارة، يتضح أنها تثثل نماذج متنوعة من قارات ثلاث ( جامعة أكسفورد بإنجلتزا في قارة أوربا، جامعة نيو سوث ويلز بسيدني في أستراليا، جامعة أوكلاند النيوزيلندية بقارة آسيا )، وأن هذه الجامعات رائدة في مجال البحث العلمي، وتتصلدر بعضها التصنيف المحلي داخل القارة والدولة ( جامعة أكسفورد، جامعة أوكلاند )، بل إن جامعة أكسفورد تصدرت قائمة التصنيفات العالية للجامعات في كثير من الأعوام، وهي من أقدم الجامعات في العالم، كما تحتل جامعة نيو سوث ويلز بسيدني مكانة متميزة على مستوى قارة أستراليا كجامعة بحثية، كما أنها تأتي ضمن أفضل مائتي جامعة في تصنيف شنفهاي المعترف به دوليًا، ومن ثم فالجامعات الثلاث بوجه عام تحتل مراتب ومراكز متميزة في تصنيفات الجامعات عاليًا ومحليًا، وبصفة عامة تتميز الجامعات الثلاثة بـأنها جامعات بحثية رائلدة في المقام الأول ؛ ومن ثم تولي اهتمامًا كبيرًا بـالبحوث والإثراف العلمي على طلاب الدراسات العليا في مرحلتي الماجستير والدكتوراه، وتضع له القواعل والسياسات المنظمة ؛ من حيث معايير اختيار المشرفين وتشكيل الفرق أو اللجان الإشرافية، وتحدد بلدقة أدوار ومسئوليات كل من المشرف والطالب خلال مراحل البحث المختلفة، وتضع ضوابط صارمة حاكمة للعلاقة الإثرافية بينمها، وتُعد وتُصمم أنشطة ووسائل وبرامج متميزة لتنمية أعضاء هيئة التدريس مهنيًا في مجال الإثراف ะ 70

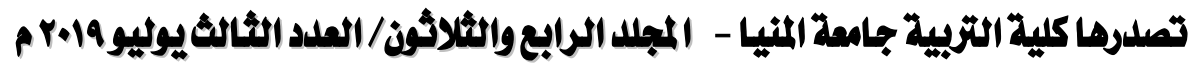
gamel_abdo59@yahoo.com

http://ms.minia.edu.eg/edu/journal.aspx 


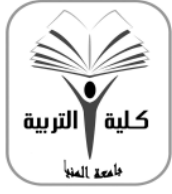

\author{
مجالة البجث في التزبية ومام النفس \\ كالية التربية - جامعة المنيا \\ كايلة مُتملمدة من الميئة القومية لضمان جودة التمليم
}

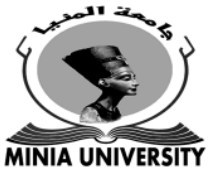

العلملي، ولعل هله الأسباب وغيرها ما دفع الباحث لاختيار تلك الجامعات لتكوذ موضع المقارنة؛ لاستخلاص دروس وأوجه استفادة تساعد في تطوير الإثراف العلمي بـالجامعات المصرية. ويسير التحليل المقارن لخبرات الجامعات الأجنبية الثلاثة المختارة والجامعات المصرية من خلال عرض أوجه الشبه والاختلاف بينها في محاور البحث المحددة سلفًا، ثم استخلاص أوجه الاستفادة من خبرات هذه الجامعات الثلاث في تلك المحاور؛ ليتم الارتكاز عليها في بناء الرؤية التطويرية المقترحة

$$
\text { ومحاورها، وذلك على النحو الآتي: }
$$

أونًا : أوجه الشبه والاختلاف :

يتم عرض أوجه الشبه والاختلاف بين نظام الإثراف العلمي في الجامعات الأجنبية موضع

$$
\text { ا- المقارنة والجامعات المصرية من خلال محاور البحث وحلدوده الموضوعية، على النحو الآتي: }
$$

تهتم الجامعات الثلاثة اهتمامًا بـالفًا بنظام الإثراف العلمي على بحوث ورسائل طلاب اللدراسات العليا بمرحلتي الماجستير والدكتوراه، وتتشابه إلى حلد كبيرٍ في آليات وطرائق إدارته وتنظيمه ، وذلك من خلال مجالس رسمية بتلك الجامعات وكلياتها وأقسامها العلمية ( مجالس الأقسام والدراسات العليا والكليات، مجلس اللدراسات العليا بـالجامعة )، وذلك كما يحلدث بـالجامعات المصرية، ولكن في ظل تشريعات وقوانين وأطرٍ منظمة تختلف كثيرًا عن الإطار التشريعي المنظم للإشراف على الرسائل العلمية بالجامعات المصرية ( قانوز تنظيم الجامعات واللوائح الداخلية للدراسات العليا ) من

حيث التفاصيل والضبط والمعيارية لكل كبيرة وصفيرة في مجال الإشراف على الرسائل والبحوث العلمية. حيث تتولى هذه المجالس بالجامعات الأجنبية الثلاث موضع المقارنة ومن يلديرها ويترأسها عملية تنظيم الإشراف العلمي على البحوث كل في اختصاصاته، فتقوم بـاختيار وتعيين المشرفين على الطلاب في ضوء معايير وقواعد واضحة تضمن مراعاة رغبة الطلاب في اختيار المشرف والمكس، ووضع سياسات وقواعد لتفيير الإشراف وإضافة مشرفين جدد في حالات محددة وبشروط وإجراءات معينة، كما تضع سياسات لتحديل الحمل الإشرافي وآليات واضحة لمتابعتها، وتحليلد واضح ودقيق لمسئوليات وأدوار المشرفين والطلاب في إنجاز الرسالة، وإرساء ضوابط وقواعد تحكم العلاقة الإشرافية بينهما، والتأكل ะ 59

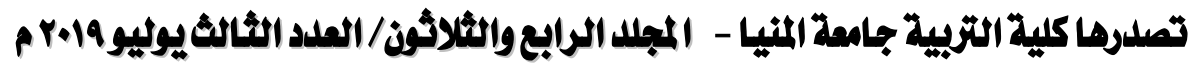
gamel_abdo59@yahoo.com

http://ms.minia.edu.eg/edu/journal.aspx 


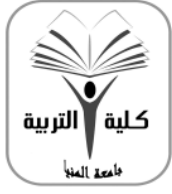

\section{مجلة البعث في التربية وعلم النفس \\ كلية التربية - جامعة المنيا}

كلية مُشتمدة من الهيئة القومية لضمان جودةالتعليم

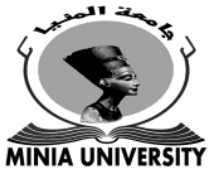

من سهولة وصول الطالب لشرفه وا لحصول على التوجيه والإرثاد واللدمم المناسب، ووضع إجراءات بليلة حالة غياب الشرف لفتزات طويلة لأية ظروف (إجازات تفرغ، حالات مرضية...إلخ)؛ تجنبًا لحرمان الطالب من الدعم والمساندة الإشرافية والتوجيه.

ولعل هذه السياسات بطبيعتها تختلف باختلاف طبيعة الجامعات الثلاث والقوى والعوامل التي تحكم مجتمعاتها ودولها، فوجود أوجه تشابه واختلاف بين هذه الجامعات في إدارة وتنظيم الإشراف العلي ربما يكون أمراً نسبيًا وضروة منهجية، فخبرات الجامعات الثلاث وإن اتفقت وتشابهت في الخطوط الثها العريضة لمحاور المقارنة بصفة عامة، فهناك اختلافات في التفاصيل والآليات والأساليب، وفيما يخص إدارةوتنظيم الإثراف على الرسائل والبحوث العلمية. فقي جامعة أكسفورد: تتولى المجالس الرسمية بالجامعة والكليات والأقسام العلمية تنظيم وإدارة الإثراف على البحوث والرسائل العلمية، فيختلف نهط ونوع الإشراف على الطلاب بهله الجامعة وكلياتها ما بين فردي أو جماعي أو مشترك بحسب طبيعة التخصص والموضوعات البحثية التي يختارها الطلاب، وما تحتاجه من توجيه ودعم ومساندة، فتختلف نوعية ونطط الإشراف ما بين كليات قطاع العلوم الطبية والطبيعية عنها في قطاع العلوم الإنسانية والاجتماعية، وحتى لا يُحرم الطالب من الدعم والتوجيه المستمر لا تقبل الجامعة المرشحين للبحث ما لم يوجد مشرف متخصص في موضوع بحثله كما لا لا تقنح الجامعة الشرف على بحوث طلاب الدراسات إجازة تفرغ إلا بعد ترتيب البديل، كما يتم إعلام الطالب بالموعد المتوقع لتعيين الإشراف على بحثه مع وضع ضمانات للأخذا برغبته في اختيار الشررفين.

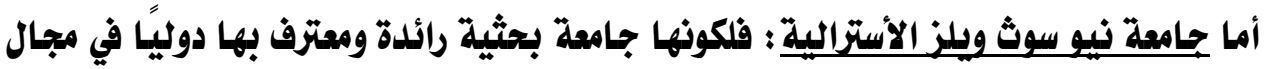
البحث العلمي والصناعة؛ فإنها تهتم بالتميز والجودة في إدارة وتنظيم الإثراف البحثي من خلال وضع أدلة ووثائق رسمية وإرشادات وإجراءات تنظيمية لتلك العملية تتطبق على جحييع الثرفين بكليات الجامعة.

وفي حامعة أوكلاند النيوزيلندية ؛ يتم اتباع نفط الإثراف الفريقي بحيث يكون لكل طالب فريق مكون من أكثر من مشرفين على الأقل (أحدهما الشرف الأساسي أو الرئيس، والثاني مشرف ثانوي أو مساعد ) بالإضافة إلى مشرف مشارك للأغراض الإدارية وقت الحاجة يختاره الشرف الأساسي، كما يوجد الثاند 纟\%

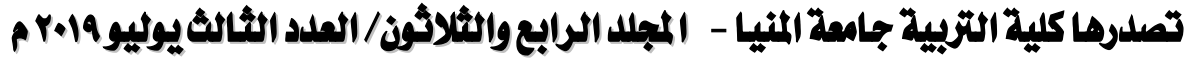
gamel_abdo59@yahoo.com

http://ms.minia.edu.eg/edu/journal.aspx 
بالجامعة هيكل إثرافي يتضمن فئات المشرفين ومعايير اختيار كل فئة، وأدوارها ومسئولياتها وحقوقها وواجباتها، كما أن الممارسات والسياسات والإجراءات الخاصة بإشراف الدكتوراه وترثيح الدكتوراه متاحة بشكل معلن على موقع مركز الدراسات العليا، ومؤطرة في أدلة سهلة الاستخدام، وفي ملونات

$$
\text { وقواعد الممارسة ودليل الطالب الباحث. }
$$

كما تتشابه الجامعات الثلاثة في إخضاعها عملية الإثراف على الرسائل العلمية للمتابعة والرقابة المستمرة للتأكل من سلامة جميع الإجراءات، وملى تلقي الطالب الباحث للدعم والتوجيه المطلوب، والتزام طرفي الإثراف بأدوارهما ومسئولياتهما في إنجاز البحث على الوجه المنشود، وإن اختلفت الجهات الرقابية والآليات والأساليب.

فقي جامعة أكسفورد تتم المتابعة والرقابة من خلال تقارير الإثراف على الدراسات العليا (GSS) التي تم استبدال مسماها على موقع الجامعة بنظام الإشراف على اللدراسات العليا (GSR) وتستخلم هذه التقارير ونتائجها من قبل ملير اللدراسات العليا للتحقيق في أية مخاوف أو مشكلات قد تؤثر على جودة الإشراف وتقدم الطالب في بحثه، كما تستخلم نتائج التقارير في عمل تفلذية راجمة لتطوير الأداء الإشرافي والبحثي للمشرف والطالب الباحث، كما يوجد قسم خاص لإدارة عملية الإثراف على البحوث ومراجعة التقدم البحثي بـالجامعة وكلياتها، وتعيين الجامعة مستشارًا للإثراف العلمي لتلقي تقارير الإثراف ومراجقتها والخروج بتفذية راجعة لتطوير الأداء الإشرافي هذا على مستوى الجامحة، كما أن لكل كلية إجراءاتها الخاصة بمتابعة ورقابة حسن سير عملية الإشراف على البحوث

$$
\text { والرسائل العلمية. }
$$

أما في حامعة نيو سوث ويلز الأسترالية فتتم المتابعة والرقابة للعملية الإثرافية من خلال المجالس الرسمية المختصة ومدراس اللدراسات العليا، ومنسق الدراسات العليا بـالجامعة والكلية، وعميل أبحاث الخريجين، وعميد البحث والتلدريب بالجامعة.

وفي جامعة أوكلاند النيوزيلندية تقم متابعة وتتظيم الإثراف العلمي على الرسائل البحوث من خلال مكتب التخطيط للهوارد البشرية بـالجامعة، وتقاريره حول بيانات المشرفين المتمدين بالجامعة وكلياتها، ومركز (CLAR) ؛ حيث لا يتم تعييز المشرفين بـالجامعة إلا بعد اعتمادهم من هذا المركز

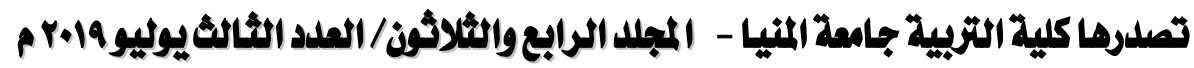
gamel_abdo59@yahoo.com

http://ms.minia.edu.eg/edu/journal.aspx 
كمشرفيز على بحوث وأطروحات الدكتوراه، كما يعقد رئيس الجامعة وعميد اللدراسات العليا اجتماعًا سنويًا دوريًا لمناقشة مسائل ومشكلات الإثراف على طلاب الدكتوراه، وتقوم الجامعة بتقديم الاعتراف وجوائز التميز للمشرفيز المتميزين على مستوى الكليات والجامعة، مع ترشيحهم للحصول على جوائز التميز في الإشراف على على مستوى الدولة وجامعاتها. وتتشابه سياسات وإجراءات تفيير المشرفيز على رسائل الطلاب في الجامعات الثلاث إلى حد كبير فتتضع جامعة أكسفورد سياسة تتضمن إجراءات محددة لتفيير واستبلدال وإضافة المشرفين على الرسائل والبحوث وفقًا لشروط محددة وفي حالات وظروف معينة، وتتشابه هذه السياسة وإجراءاتها وحالاتها وشروطها مع سياسة جامعة نيو سوث ويلز الأسترالية، مع تأكيد الأخيرة على ضرورة تفيير الإشراف عند توتر العلاقة الإثرافية بين المشرف والباحث وعلدم التوافق بينهما مع تبرير كلا الطرفين بأسباب وجيهية يتم التحقيق فيها، وفي جامعة أوكلاند النيوزيلندية بالإضافة إلى هذه السياسة وإجراءاتها توجد قواعد وسياسات خاصة بإجازات للتفرغ البحثي للمشرفين أو لأية ظروف أخرى، كما يوجد سياسة تنظم إجازات الطاب، وعلى كل من الطرفين إبلاغ بعضهما بهوعد الإجازات، ثم التوافق وإبالاغ الجامعة لأخذ الموافقة مع تدبير البلديل حال إجازة المشرف لاستكمال التوجيه واللدم للطلاب، أو تحليد وسائل التواصل بين المشرف والطالب حال الموافقة على إجازة الطالب لاستمرار التواصل الإثرافي والتقلم

كما تتشايه الجامعات الثلاثة في اهتمامها بوضع سياسات محددة وواضحة للعبء أو الحمل الإشرافي أو النصاب الإشرافي لكل عضو هيئة تدريس، وإن اختلفت هذه الأحمال من جامعة إلى أخرى. فتي حامعة أكسفود يختلف النصاب الإثرافي لعضو هيئة التدريس بـاختلاف التخصصات البحثية لكليات كل قطاع بـالجامعة، فقي كليات قطاع العلوم الطبية لا يجوز لعضو هيئة التدريس الإشراف على أكثر من ( 7 ) طلاب في وقت واحل، وبـالمثل في كليات قطاع العلوم الإنسانية، وذلك مراعاة الأعباء التدريسية والإدارية والبحثية وأنشطة خدمة المجتمع المُلقاة على عاتق عضو هيئة التدريس؛ حتى يستطيع المثرف القيام بـأدواره ومسئولياته تجاه طلابه على أكمل وجه ، ويقل هذا العدد إلى ( - ع ) طلاب بكليات قطاع العلوم الاجتماعية، ولا يجوز قبول الطالب بجامعة أكسفورد إلا إذا كان هناك $\leq 79$

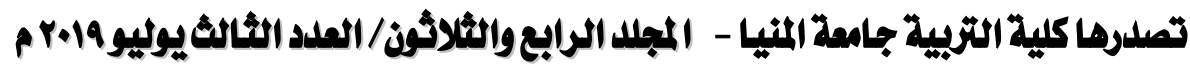
gamel_abdo59@yahoo.com

http://ms.minia.edu.eg/edu/journal.aspx 
إشراف متخصص بـالجامعة أو الكلية أو القسه في الموضوع اللذي اختاره الطالب.

أما في جامعة نيو سوث ويلز فيختلف العبء الإشرافي بـاختلاف فئسات المشرفيز، فلا يجوز للمشرف الأساسي المعتمد أن يشرف على أكثر من ( 7 ) طلاب بحث متفرغين إلا بإثبات أن للديه الوقت الكافي للإثراف على أكثر من ذلك، ولا يتم هذا الاستثناء إلا من خلال العرض على المجالس الرسمية المختصة، أما المشرف الثانوي أو المساعد فلا يزيلد في إشرافه بـأي حال عن ( ج ) طلاب، وتُخضع الجامعة الأحمال الإشرافية لأعضاء هيئة التدريس للمتابعة والرقابة من قبل عميل اللدراسات العليا بـالجامعة أو الكلية، ويزود عميد الدراسات العليا عميد الجامعة للتدريب والبحث بتقارير حول عدالة توزيع العبء الإثرافي بكليات الجامعة وأقسـامها.

وفي جامعة أوكلاند النيوزيلندية لا يقوم المشرف المعتمد عادة بـالإثراف على أكثر من ( 7 ) طلاب بحث مثفرغين في وقت واحد، ويتم احتساب ساعات الإثراف بالنقاط ( • ا ) ثقطة لكل رسالة ماجستير أو دكتوراه، ( • ) نقطة للمشروع البحثي، كما يتم التأكيد على توزيع الإثراف بشكل عادل ومناسب، بحيث تتوازن هذه المسئولية مع الالتزامات والأعباء التدريسية والبحثية والإدارية للمشرفين. أما بـالنسبة للجامعات المصرية فمن خلال تحليل الواقع والوضع الراهن للإثراف العلمي بالجامعات المصرية، يتبين أنه على الرغم من التشابه في جهات الإدارة والتنظيم للإشراف العلمي إلى حلد كبير بينها وبين جامعات المقارنة من قبل المجالس الرسمية، إلا أنه يغيب عن هذه المنظومة الإثرافية كثيرًا مما هو موجود بنظام الإثراف العلمي بـالجامعات الأجنبية الثلاث، من عدم وجود سياسات وقواعد تنظيمية وسياسات إدارية محددة واضحة تراعي معايير اختيار المشرفين وأخد رغبة الباحث بالاعتبار في عند الاختيار والتعيين، أو تحليل واضح لأدوار ومسئوليات المثرفين والطلاب وحقوقهم وواجباتهه، أو تنظم العلاقة الإثرافية بينهما وفقًا لضوابط وأسس وقواعد محددة، أو إرساء سياسة موحدة واضحة للحمل الإثرافي، وإجراءات تفيير واستبلدال المشرفين وحالاتها وشروطها، غياب أساليب متابعة وتتويم ورقابة العملية الإثرافية بجوانبها وأركانها المختلفة، وإن وُجدت بعض هذه السياسات والقواعد فتطبيقها على أرض الواقع لا يتطابق مع ما تقصه عليه في أغلب الأحيان. 
r - معالير اختيار المشرفيز وتشكيل لجحاز الإشراف العلمي:

تشابهت الجامعات الأجنبية الثلاث في اهتمامها المتزايل بوضع معايير لاختيار المشرفين وتشكيل لجان الإثراف على الرسائل العلمية، وتنص هذه المعايير بصفة عامة في تلك الجامعات على أن يكوز المشرف عضوا من أعضاء هيئة التدريس بـالجامعة، وحاصل على درجة الدكتوراه أو ما يعادلها، ولديه الخبرة والوقت الكافي للإثراف، وأن يكون متخصصًا في مجال الرسائل والأطروحات التي يشرف عليها، وله مؤلفات وأنشطة بحثية في مجال التخصص، وحضر برامج تنمية مهنية وتدريبات في مجال الإشراف العلمي. وقد حرصت الجامعات الثلاث على تطبيق هذه المعايير وغيرها عند تشكيل لجان الإثراف على الباحثين، وإن اختلفت بعض هذه الجامعات في استثناءات لبعض الشروط بحسب فئة المشرف (رئيس، ثانوي أو مساعد، مشارك.. .إلخ ). فقي حامعة أكسفورد توجد معايير وشروط لتعيين كل فئة من فئات المشرفين يجب توافرها للاختيار والتعيين ضمن لجان الإثراف العلمي، كما لا تقبل الجامعة المرشيح أو الباحث إذا لم يكن هناك مشرف في ذات تخصص الموضوع الذي اختاره، وفي حالات نادرة يُستمان بمشرفيز متخصصين من الكليات والأقسام العلمية المناظرة بالجامعة أو خارجها هذا بـالنسبة لكليات قطاع العلوم الإنسانية والاجتماعية، وأما في مجال العلوم الطبيعية فلابل من تتطابق المعايير السابقة إضافة إلى قدرة المشرف وخبرته في الحصول على دعم ونفقات مناسبة لتفطية مشروع بحث الطالب، وإبرام عقد مع الجامعة لإنجاز أبحاث الطالب، كما تتطبق كليات العلوم الطبية بجامعة أكسفورد معيارًا إضافيًا مهمًا وهو علم جوازتعيين المشرف المساعد أو المشارك مشرفًا رئيسًا إلا إذا أُجيز له طالب على الأقل. وتتشابه حسمعة نيه سوث ويلز مع جامعة أكسفورد في كثير من المعايير الخاصة بـاختيار وتعيين الشرفين من الفئات المختلفة ( رئيس، مساعد، مشارك ) باستثناء اختلافها في شرط تعيين المشرف المساعد أو الثشارك مشرفًا رئيسًا في فريق الإثراف إذا أُجيز له طالبين وليس طالبًا واحلًا، بـالإضافة إلى التأكيد على حضور برامج التنمية المهنية والتدريبات في مجال الإثراف كثرط للإثراف، كما أن الجامعة تسمح بالإثراف المساعد أو المشارك من خارج الجامعة في مجال التخصص من داخل الإدارات الحكومية أو المعاهد \& $v 1$

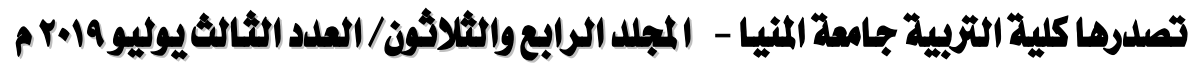
gamel_abdo59@yahoo.com

http://ms.minia.edu.eg/edu/journal.aspx 
والمراكز البحثية والمكتبات والمتاحف والمصانع؛ لتوفير الخبرة الميلدانية للطالب وللمشروع البحثي لاسييما وإذا كان من المقرر أن يقضي الطالب فترة من الوقت داخل مختبر أو مصنع أو متحف ...إلخ، وتعمل الجامعة على تأكيد المعايير الخاصة باختيار وتعييز كافة المشرفيز، وفي حالات قليلة أو نادرة يتم استبعاد أو تعليق عمل المشرفين غير المؤهلين إذا ثَبُت تقصيرهم في أدوارهم ومسئولياتهم مع قيام عميد أبحاث الخريجين ( نائب رئيس الجامعة للدراسات العليا ) بإبلاغ المشرف بـالقرار وحيثياته وأسبابه مع إعطائه مساحة منز الوقت وفرصة للرد. وأما حامعة أوكلاند النيوزيلندية فتتشابه مع الجامقتين السابقتين من حيث معايير اختيار الشرفين بفئاتهم المختلفة، بينما تختلف في تأكيد معيار فريد هو اعتماد جميع المشرفين من قبل مركز اللدراسات العليا ومركز (CLRA) للتعليم العالي كمشرفيز معتمدين، والتأكلد من قدراتهم على القيام بمسئوليات الإثراف، كما أن الجامعة تُجيز تعيين مشرف كناصح للباحث هو عضو خبير في مجال التخصص، أو عضو نشط في مجال التخصص قد يكوز غير حاصل على درجة الدكتوراه. أما بـالنسبية للحامعات المصرية، فلم تنص التشريعات المنظمة أو اللوائح الداخلية للدراسات العليا لمعظم الجامعات وكلياتها في أغلب الأحيان على معايير لاختيار وتعييز المشرفيز غير اللدرجة العلمية والتخصص العام في مجال الرسالة، وفي حالة تعلد المشرفين يجوز اشتراك أعضاء هيئة التدريس بلدرجة ملدرس في الإشراف على رسائل الماجستير والدكتوراه مع استفياء بعض الشروط تحددها الجامعات كإجازة رسالة ماجستير أو نشر بحث في التخصص مع مرور ثلاث سنوات على تاريخ تعيينه بالدرجة العلمية أو غيرها من الشروط بـالنسبة للإثراف على رسائل الدكتوراه، وذلك كما سبق الإثارة إليه في المحور الخاص بواقع الإثراف العلمي بـالجامعات المصرية ووضعه الراهن.

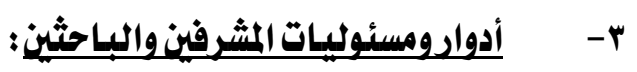
تشابهت الجامعات الأجنبية موضع المقارنة في اهتمامها المتزايل بتحليد أدوار ومسئوليات لكل من المشرف والطالب خلال العملية الإثرافية ومرحل البحث المختلفة؛ من أجل إحداث التعاوز في إذجاز البحث على الوجه المنشود، حيث يوجد بكل جامعة وثيقة أو كود أو قائمة تحدد الأدواروالمسئوليات الفنية العلمية والإدارية التنظيمية والأخلاقية والإنسانية لطرفي عملية الإشراف خلال مراحل إنجاز الرسالة أو 


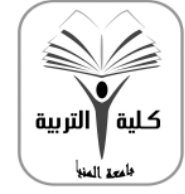

\section{مجالة البجث في التزبية ومام الثفس \\ كايلة التزبية - جامعة المثيا}

كلية مُقتملةمن الميية القومية لضمان جودةالتمليم

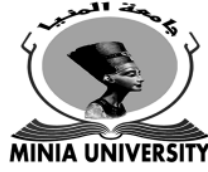

MINIA UNIVERSITY

الأطروحة، وقد تختلف هذه الأدوار بيز الجامعات الثلاثة اختلافًا طفيفًا زيادة أو نقصان تفصييًا أو إجمايًا.

فقي جامعة أكسفورد توجد قائمة بتلك الأدوار والمسئوليات وتتم المراجعة والمتابعة للأداء

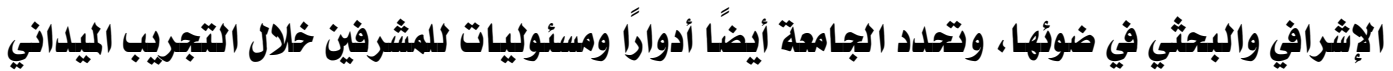

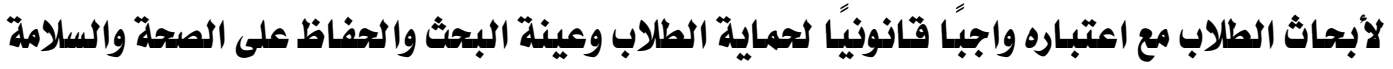

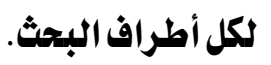

أما في حامعة نيو سوث ويلز فتحدد الجامعة أدوارًا ومسئوليات فنية وإدارية خاصة بكل فئة من المشرفين (الأساسيين، والمساعلين، والمشاركين، والفريق الإشرافي ) وذلك خلال مراحل البحث المختلفة، كما تهتم بالمسئوليات الأخلاقية للشرف لتفضيد السلوك البحثي والأخلاقي القويه، كما تقيزت هذه الجامعة بتأكيد أدوار الشرف خلال عملية مناقشة وفحص الرسالة من مشاركة الطلاب والتعاون معهم في الإعداد والترتيب لهذه العملية وأخذ رغبتهم ورأيهم في اختيار أعضائها، وإجراء التعديلات الخاصة

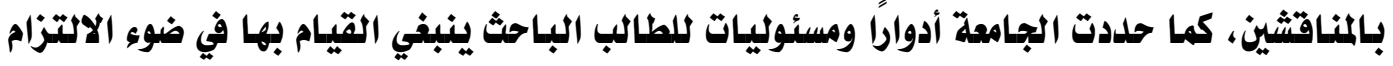
بقواعد الجامعة والكلية والقسم التتعلقة بإجراء البحوث والرسائل العلمية. وفي حامعة أوكلاند توجد وثيقة إرشادات الإثراف على اللدراسات العليا بالجامعة وقائمة أدوار ومسئوليات حول ما هو متوقع من الشرفين بفئاتهم المختلفة ( أساسي، مساعل، مشارك ) والطالب الباحث في العملية الإثرافية خلال مراحل البحث المختلفة قبل التسجيل وبلداية الدراسة وأثناء التسجيل واللدراسة وحتى التحضير للنناقشة وما بعدها إلى حصول الطالب على اللدرجة العلمية ومساعدته في الجصول على وظيفة أحيانًا. أما بـالنسبية الجحامعات المصرية فنادراً ما يوجد تحديد واضح ودقيق لأدوار ومسئوليات كل من المشرف والطالب بالتشريعات المنظمة للإثراف العلمي أو القوانين واللوائح اللداخلية بتلك الجامعات، فالأمر في الجامعات المصرية لا يتجاوز النص على أن الطالب يقوم بإعداد الرسالة تحت إثراف أستاذ أو

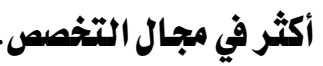

\section{$\varepsilon V r$}

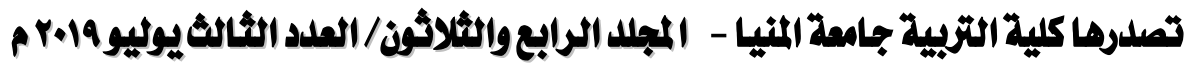
gamel_abdo59@yahoo.com

http://ms.minia.edu.eg/edu/journal.aspx 
؟- العلاقة الإشرافية بين المشرفوالباحث:

تشابهت الجامعات الثلاث موضع المقارنة في تأكيد الاهتمام بقضية العلاقة الإثرافية بين المشرف والباحث، وجملها لب وقلب وصميي عملية الإثراف العلمي ومفتاح النجاح في إنجاز البحوث والرسائل العلمية، ومن ثم عمِلت الجامعات الثلاث- كثيرها من الجامعات الأجنبية المتقدمة- على وضع أسس ومبادئ وضوابط صارمة لتنظيي هذه العلاقة مهنيًا واجتماعيًا وأخلاقيًا وإنسانيًا، فقامت بوضع معايير مهنية وأخلاقية لاختيار المشرفين، وتحليل الأدوار والمسئوليات والتوقعات لكل من المشرف

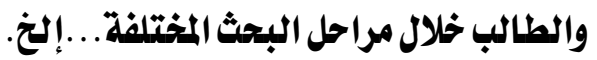
فقي جامعة أكسفورد تم وضع أسس ومبادئ تحكم هذه العلاقة في جميع قطاعات البحث داخل الجامعة من خلال تحليل التوقعات المتبادلة من المشرف والطالب خلال العملية الإشرافية، ووضع مواثيق أخلاقية ومهنية تحكم السلوك البحثي وتنظم هذه العلاقة، ووضع سياسة محددة لتفيير المشرفين أو إزالتهم وعزلهم من الإشراف حالة توتر وانهيار العلاقة الإشرافية بينهم وبين طلابهه لأسباب أخلاقية أو أكاديمية، وتشابهت معها في ذلك جامعة نبيو سوث ويلز مع تأكيدها على الالتزام بساسية تضارب المصالح عند تعيين واختيار المشرفين للباحثين، وقد سارت جامعة أوكلاند في نقس المسار لإرساء دعائم علاقات إشرافية ناجحة بين طلابها ومشرفينهه. أما بالنسبة للجامعات المصرية فتستخلم بعض الآليات لمتابعة حسن سير العلاقة الإثرافية فثثًا قبل الإثراف يتم توقيع إقرارات علدم صلة قرابة المشرف بـالباحث تعضيدًا لسياسة علدم تضارب المصالح، كما تهتم بعض الجامعات بالتحقيق في الشكاوى حول مشكلات الإشراف وخاصة فيما يتعلق بالعلاقة الإشرافية حال استحالة استمرارها. - - التنمية المهنية لأعضاي هبئة التدريس في مجال الإشراف العلمي: تشابهت الجامعات الأجنبية الثلاث في الاهتمام المستمر بعملية التنمية المهنية لأعضاء هيئة التدريس وتلدريبهم في مجال الإثراف على الرسائل والبحوث مع اعتبار حضور التدريبات إلزاميًا مجانيًا وشرطًا للإشراف؛ وذلك إيمانًا منها- كمفظم جامعات الدول المتقدمة- بـأهمية الإشراف العلمي في 
تجويل البحوث والرسائل العلمية، وقد تشابهات بعض آليات وأنشطة التنمية المهنية في تلك الجامعات من خلال مواقع إلكترونية مصممة خصيصًا لهذا الفرض، ودورات تدربيية، وورش عمل، وحلقات دراسية وبجثية "سيمنارات" .. .إلخ، في حين اختلفت بعض جهات وآليات وأساليب التنمية المهنية في مجال الإثراف

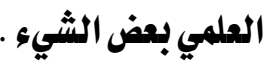
فقي جامعة أكسفورد تثم التنمية المهنية والتدريب في مجال الإشراف العلمي من خلال معهد أكسفورد التعليمي وموقعه الإكتروني "الإشراف على البحوث"، حيث يقلدم الموقع معلومات مهمة حول الإشراف العلمي وممارساته وكل جليل حول أساليبه الحليثة، بـالإضافة إلى الدورات وورش العمل وحلقات الإشراف التي يقدمها المعهل. أما حامعة نبيو سوث ويلز فيتولى اللدم والتدريب للمشرفيز مركز اللدراسات العليا، ووحلدة تقديم الخدمات والاستشارات النفسية (CAPS) ، ومنسقو اللدراسات العليا بـالجامعة والكليات، وعميد اللدراسات العليا، وعميد الجامعة للتدريب والبحث، ويتم التدريب من خلال دورات ونلدوات وورش عمل وجها لوجه أو عبر الإنترنت. وفي جامعة أوكلاند تتم التنمية المهنية للمشرفين من خلال موقع جامعة أوكلاند الإكتروني، ومركز (CLAR) للتعلم والبحث في التعليم العالي، ويتم تقلديم أنشطة مختلفة للتنمية المهنية في مجال الإشراف مثل: اللدورات التدريبية والندوات وورش العمل، وحلقات الإشراف ويتم التدريب وجهاً لوجه أو عبر الإنترنت، كما تقدم الجامعة أدلة إرشادية وكتيبات ورقية وإكترونية حول الإشراف العلمي وممارساته وأساليبه الحليثة. أما الجحامعات المصرية فيتضح من خلال تحليل الوضع الراهن ضعف الاهتمام بالتنمية المهنية لأعضاء هيئة التدريس خاصة في مجال الإثراف على الرسائل العلمية، حيث خلت برامج معظم مراكز تثمية قدرات أعضاء هيئة التدريس من وجود دورات تدريبية في مجال الإثراف العلمي، بـالإضافة لقصور دور معظم الجامعات والكليات والأقسام العلمية في القيام بأنشطة للتنمية المهنية في مجال الإثراف العلمي، ولم تشترط معظم الجامعات للإثراف على الرسائل العلمية حضور تدرببات أو تنمية مهنية في تهية

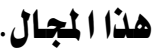
$\varepsilon \vee 0$

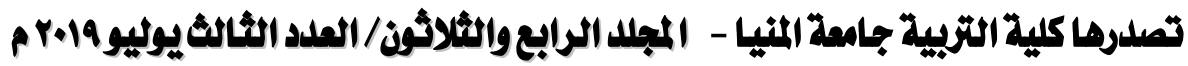
gamel_abdo59@yahoo.com

http://ms.minia.edu.eg/edu/journal.aspx 
وفي ضوء ما سبق ، يتضح أن أوجه الشبه والاختلاف بين خبرات الجامعات الثلاث المختارة في مجال الإشراف على الرسائل والبحوث العلمية هو أمر نسبي، وضرورة منهجية، فهناك أوجه تشابه عامة تارة، وأوجه اختلاف تفصيلية تارة أخرى، وذلك على الرغم من أن سياسات الإثراف على البحوث والرسائل العلمية والاهتمام بإدارته وتنظيمه ووضع ضوابط لكل إجراءاته وممارساته في الجامعات الثلاث تكاد تكون واحدة؛ وقد يرجع ذلك لتشابه طبيعة ونهط الجامعات ومحيطها الثقافي والاجتماعي، الأمر الذي جعل هناك مجموعة من الدروس وأوجه الاستفادة التي يمكن استخلاصها من هذا التحليل المقارن والارتكاز عليها في بناء الرؤية التطويرية المقترحة ومحاورها بما يتناسب والسياسات البحثية بالجامعات المصرية، وثقافة المجتمع المصري وظروفه. ثانيًا : أوجه الاستفادة من خبرات الجامعات الأحنبية الثلاثة في الإشراف العلمي (نتائج التحليل المقارن ):

وفي ضوء ما توصلت إليه خطوة الوصف لنظام الإثراف العلمي بـالجامعات الأجنبية الثلاثة المختارة، والتحليل المقارن لأوجه الشبه والاختلاف بيز تلك الخبرات الثلاثة والجامعات المصرية في هذا المجال، يتضح أن الإثراف العلمي بـالجامعات المصرية يعاني كثيرًا من أوجه القصور والمشكلات مقارنة بما هو قائم في الجامعات الأجنبية موضع المقارنة، وهذا ما أكدته خطوة تحليل الواقع والوضع الراهن للإثراف العلمي بـالجامعات المصرية؛؛ وعليه يمكن استخلاص مجموعة من اللدروس وأوجه الاستفادة من خبرات تلك الجامعات الأجنبية لتقويم وتطوير نظام الإثراف على الرسائل العلمية بـالجامعات المصرية، يتم الارتكاز عليها في بناء وصياغة الرؤية التطويرية المقترحة ومحاورها، ويمكن عرض هذه الأوجه واللدروس بإيجازمن خلال النقاط الآتية: 1- الاهتمام بوضع سياسات وخطط وقواعل واضحة لإدارة وتنظيم عملية الإشراف العلمي على الرسائل العلمية على مستوى الجامعات المصرية وكلياتها وأقسامها العلمية، تتضمن أهدافه

$$
\text { وغاياته وأدواره ومسئولياته ...إلخ. }
$$

r- ضرورة مراعاة طبيعة التخصص العام والدقيق لعضو هيئة التدريس عند تعيينه مشرفًا على الرسائل العلمية لطابله في ضوء موضوعات ومجالات تلك الرسائل.

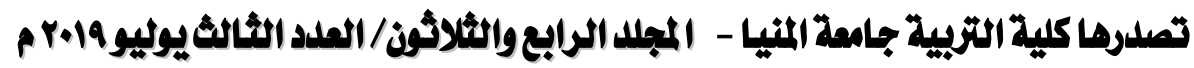
gamel_abdo59@yahoo.com

http://ms.minia.edu.eg/edu/journal.aspx 


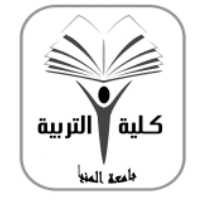

\author{
مجالة البجث في التزبية ومام الثفس \\ كايلة التزبية - جامعة المثيا
}

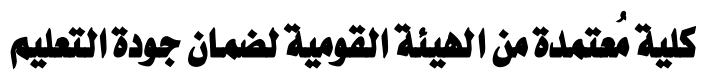

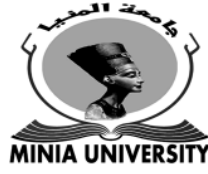

r- وضع قواعلد وقرارات تنظم إجازات التفرغ البحثي لأعضاء هيئة التدريس المشرفين، بما لا يحرم

الطالب من اللدعم والتوجيه والمساندة، ويجنبه التأخر والتثثر في إنجاز رسالته.

צ- تصميم أدلة وكتيبات ورقية وإلكترونية تحلد وتشرح إجراءات الإشراف العلمي وأدواره

ومسئولياته خلال العملية الإشرافية، وتحدد دوركل من المشرف والطالب في إنجاز البحث.

- - تأسيس نظام لمتابعة ورقابة العملية الإثرافية وإجراءات تعيين المشرفين، وملى قيامهي

بمسئولياتهم وأدوارهم تجاه البحث والباحث، وملى سلامة العلاقة الإشرافية بينهما.

1- تأسيس نظام لتدريب أعضاء هيئة التدريس واعتمادهم في مجال الإشراف العلمي وتتميتهم مهنيًا

من خلال أنشطة وبرامج علمية هادفة، ويشتراط الحصول عليها كمسوغ للإثراف العلمي وخاصة

للمشرفين المبتدئين على أن تكوز مجانية.

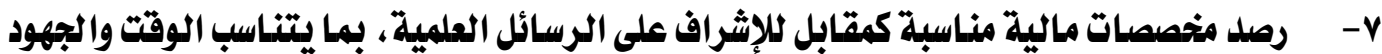

المبذولة من المشرف في عملية الإثراف أسوة بـالجامعات المتقدمة.

1- - صياغة ساسية واضحة تتضمن إجراءات إدارية مرنة لتفيير المشرفين على الرسائل العلمية في

الحالات والظروف المختلفة كمرض المشرف أو سفره أو إعارته أو انتلابه أو وفاته أو حالات علم

التوافق بين المشرف والطالب أو بين بعض المشرفين حال تعدد الإشراف، بما لا يضر بمصلحة

الطرفين.

9- وضع سياسة محددة واضحة للحمل الإثرافي أو النصاب الإثرافي لكل عضو هيئة تلدريس يته

الالتزام بها، مع وضع آليات لمتابعة تنفيذها على أرض الواقع، وضع نظام للمسايلة والمحاسبية

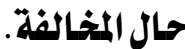

•- وضع معايير واضحة محددة لاختيار المشرفيز على الرسائل العلمية، وآليات لتشكيل لجان الإشراف العلمي، بعا يضمن أهلية المشرف للقيام بمسئولياته وأدواره في إنجاز الرسالة العلمية، ومراعاة

$$
\text { رغبة الباحث والمشرف -كلما أمكز- عند الاختيار. }
$$

11- تعييز عضو هيئة التدريس ( بلدرجة ملدرس ) على رسائل الدكتوراه بعد مرور سنتيز من تاريخ تعيينه باللدرجة، مع إجازة رسالة ماجستير أو نشر بحث في مجال تخصصه أو حضوره دورة تدريبية

\title{
$\varepsilon V V$
}

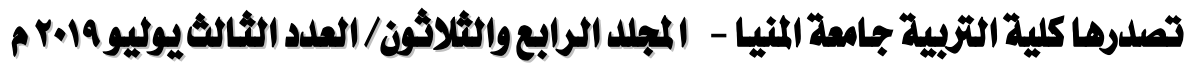

gamel_abdo59@yahoo.com

http://ms.minia.edu.eg/edu/journal.aspx 


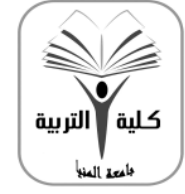

$$
\text { مجلة البعث في التربية وعلم النفس التربية - جامعة المنيا }
$$

كلية مُشتمدة من الهيئة القومية لضمان جودةالتعليم

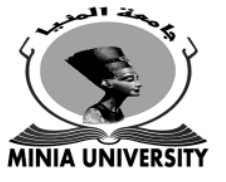

في مجال الإثراف العلمي.

rا - التوسع في الإثراف الثشتك بين أعضاء هيئة التدريس وخبراء الميدان في المجالات البحثية المختلفة

في العلوم والزراعة والصناعة والتربية والتعليم ... إلخ.

rا- وضع قائمة محددة بـأدوار ومسئوليات كل من المشرف والطالب خلال مراحل البحث المختلفة من بلداية اختيار موضوع البحث حتى المناقشة والفحص وإجراءاتها وصوئًا لمنح الباحث الدرجة العلمية، وتضميز هذه القائمة باللوائح اللاخلية للدراسات العليا بالجامعات المصرية، ووضع آليات لمتابعة الالتزام بها من قبل الشرف والطالب، ووضع نظام للمحاسبية والمساءلة حال

$$
\text { التقصيز من أي طرف. }
$$

عا- الاهتمام بقضية العلاقة الإشرافية بين الشرف والباحث، ووضع أسس ومبادئ وضوابط لتنظيهها وإرسائها على دعائم سليمة، مع وضع آليات للمتابعة والمحاسبية والمساءلة حال خروج هذه

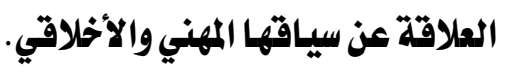

10- الاهتمام بتقليم جوائز التميز في مجال الإشراف العلمي لأعضاء هيئة التدريس المتميزين على

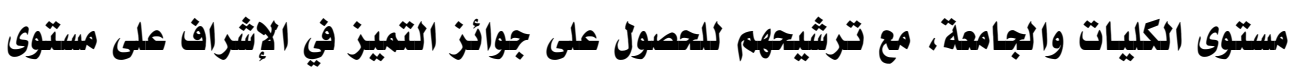

$$
\text { الدولة وجامعاتها، وللجوائز العالية في مجال البحث والإشراف العلئي. }
$$

17- الاهتمام بالتنمية الهنية لأعضاء هيئة التدريس في مجال الإشراف العلمي من خلال (المواقع

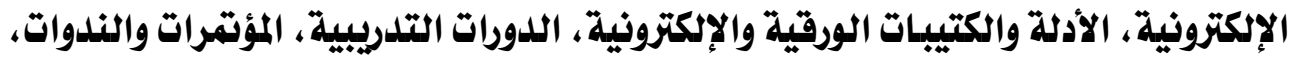
ورش العمل، وحلقات الإشراف ...إلخ)، مع جعلها إلزامية ومجانية وخاصة للمشرفين المبتدئين

$$
\text { وشرطًا للإشراف على طلاب الدكتوراه. }
$$

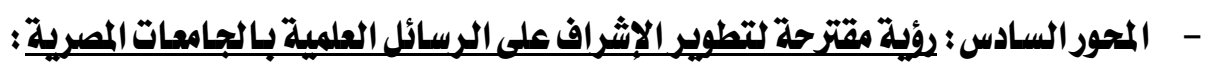
في ضوء مشكلة البحث وأهدافه، وما عرضه من دراسات سابقة وإطار نظري مفاهيمي، وتشخيص وتحليل لواقع الإثراف العلمي ووضعه الراهن بالجامعات المصرية، واستعراض خبرات الجامعات الأجنبية

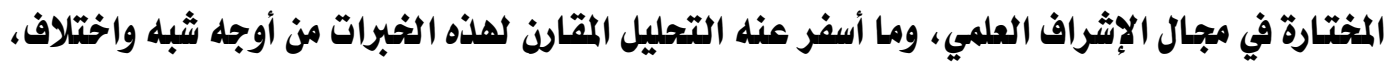
وما تم استخلاصه من أوجه استفادة، يقدم البجث رؤية مقتزحة لتطوير الإشراف على الرسائل العلمية

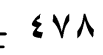

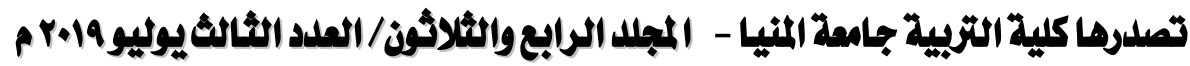
gamel_abdo59@yahoo.com

http://ms.minia.edu.eg/edu/journal.aspx 
بالجامعات المصرية، وذلك من خلال عدة محاور تتمثل في الآتي : ( فلسفة ومنطلقات الرؤية، وأهدافها، محاور وأبعاد الرؤية وما تتضمنه من إجراءات مقترحة للتطوير، وآليات وتوصيات قد تسهم تنفيذ الرؤية المقترحة )، ثم تقدليم درسات وبحوث مستقبلية مقتزحة في مجال الإثراف العلمي، وذلك على النحو

أونًا : قلسفة ومنطلقات الرؤية المقترحة:

من خلال ما قدمه البحث من إطار نظري مفاهيمي حول طبيعة الإشراف العلمي، وما أسفر عنه تشخيص وتحليل الواقع والوضع الراهن لنظام الإثراف العلمي بـالجامعات المصرية من أوجه قصور وسلييات في إدارته وتنظيمه وتشريعاته فنيًا وإداريًا وماليًا، وضعف معايير اختيار المشرفين وتشكيل لجان الإثراف، وقلة الوعي والمعرفة الكافية من المشرف والطالب لأدوراهما ومسئولياتهما خلال مراحل البحث المختلفة في ظل غموض هذه الأدوار وعلم تحلديلها بلدقة باللوائح اللاخلية للدراسات العليا بمعظم الجامعات المصرية، وغياب الضوابط والقواعد المنظمة للعلاقة الإشرافية بيز الأستاذ والطالب، وضعف الاهتمام بأنشطة وبرامج التنمية المهنية لأعضاء هيئة التدريس في مجال الإثراف العلمي، وفي ضوء ما استعرضه البحث من خبرات جامعات أجنبية مختارة في هذا المجال، تتمثل فلسفة ومنطلقات الرؤية المقترحة في النقاط الآتية: ا - الإثراف العلمي على رسائل الماجستير والدكتوراه بـالجامعات المصرية من أهم أدوارووظـائف عضو هيئة التـدريس البحثية ؛ حيث إن جـودة الرسـائل العلمية بـالجامعات المصرية وكلياتها تتوقف بلدرجة كبيرة على جودة العملية الإشرافية، وملى جودة وخبرة المشرفين.

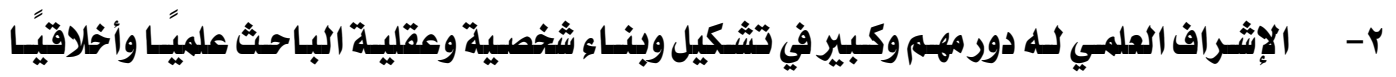
وثقافيًا واجتماعيًا، وعليه تُعقد الآمال لتخريج جيل من الباحثين المبلدعين. r- الإثراف العلمي نظام أصبح أكثر تعقيـلًا وصعوبة في ظل التطور العلمي والتكنولهوجي والرقيمي والانفجـار المعـرفي، وتزايـلـ الطلـب الاجتمـاعي على اللدراسـات العليـا بمـرحلتي الماجسـتير والدكتوراه ؛ ومن ثم ينبفي الاهتمـام بهذا وعناصره وأطرافه والعمل على تطويره وتحسينه ؛ إيمانًا بلدوره في تجويد البحث العلمي. $\leqslant \vee q$

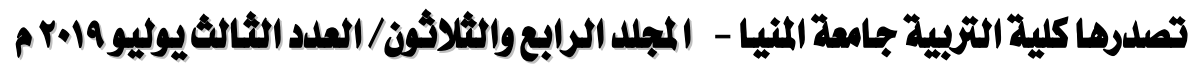
gamel_abdo59@yahoo.com

http://ms.minia.edu.eg/edu/journal.aspx 
ع- أعضاء هيئة التدريس المشرفيز على الرسـائل العلمية بـالجامعات المصرية ينبفي أن يكونوا على وعي ومعرفة كاملة بطبيعة الإثراف العلمي، وبسأدوارهم ومسئولياتهم وحقوقهم وواجبـاتهم في العملية الإشرافية، والعوامل والمتفيرات المؤثرة فيها، واللوائح والقوانين المنظمة لها. 0- عملية الإثراف العلمي تتضمن انقيـاد الباحث وانصياعه لمشرفه أو لجنة إشرافه ، كما تتضمن توقعات لأدوار متبادلة بين طرفي العملية الإشرافية ( المشرف/ الباحث ) تتداخل فيها علاقة القوة ( قوة العلم والخبرة والتخصص ) لصالح المشرف، والوعي بوجود هـذه التوقعـات وحلدودها ووضعها في نطاقها الطبيعي واعتمادها في أدوار محددة وواضحة يسـاعد في نجاح المشرف والباحث على بـ إخراج عمل علمي متميز.

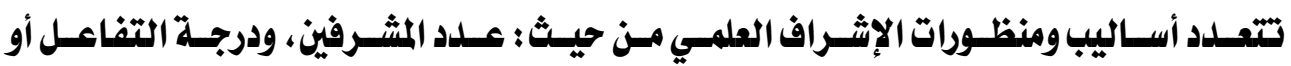

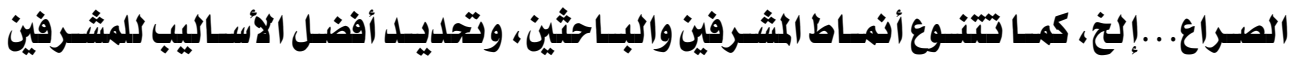
والبـاحثين وتجنب الأنمساط المضـادة يسهـه بلدرجـة كبيرة في نجـاح العمليـة الإثـرافية، وإنجـاز الرسالة العلمية على الوجه المنشود. - - العلاقة الإثرافية العلمية والاجتماعية والإنسانية بـين الأستاذ المشرف والطالب الباحث تقثل قب ولب العملية الإثرافية، ومن ثم ينبفي وضع الضوابط والقواعلد ورسم الحلدود لهده العلاقة

\section{وطبيعتها ونطاقها.}

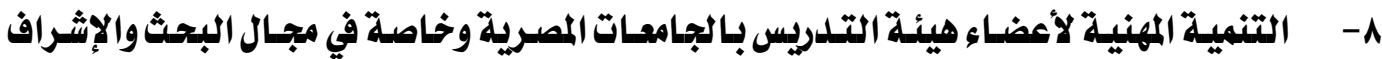
العلمي عملية غاية في الأهمية؛ ليستطيع أعضاء هيئة التدريس أداء أدوارهم البحثية والإثرافية بكفاءة وجودة عالية، والوقوف على المستجدات والمتفيرات في مجال البحث والإثراف العلمي.

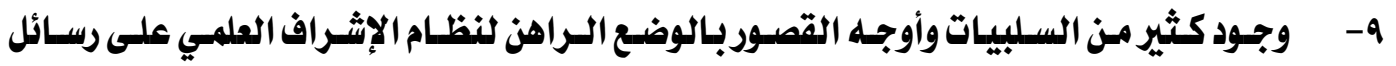

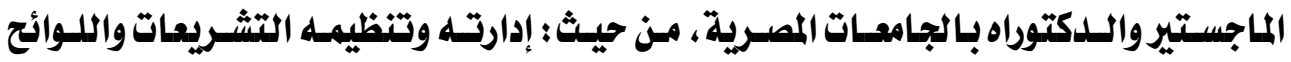

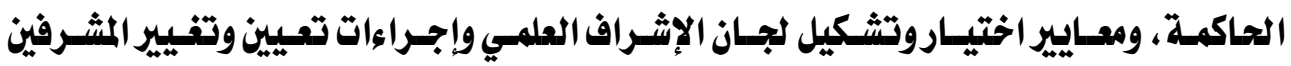
واستبلدالهم، وتحليلد أحمالهم الإثرافية، وأداء المشرفين والبـاحثين لأدوارهمـا ومسئولياتهما، وقةلـة المعرفة الكافيـة بـالحقوق والواجبـات، وقلـة الاهتمـام بـالتنميـة المهنيـة لأعضـاء هيئسة $\varepsilon \wedge$.

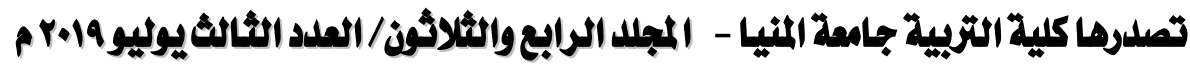
gamel_abdo59@yahoo.com 
التدريس في مجال الإشراف العلمي.

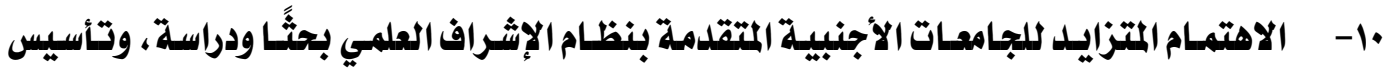
ووضع قواعلد ومعايير وشروط واضحة لكل ركن من أركانه في مقابل ضعف الاهتمام بهـذا المجال في الجامعات المصرية والعربية؛ مما يلدفع إلى المزيـلـ من البحث والدراسة والاستقصساء لسـد الفجوة والندرة في الأبحاث والدراسات الخاصة بهلذا المجال على الصعيد العربي والمصري خاصة. ثانياًا : أهداف الرؤية المقتزحة: تهلدف الرؤية المقترحة إلى تقليم بعض المقترحات والإجراءات والتوصيات لتطوير الإشراف على الرسائل العلمية بـالجامعات المصرية، والعمل على علاج السلبيات والمشكلات وأوجه ، وضمان جودة عناصر الإشراف العلمي، ويتفرع من هذا الهدف الرئيس الأهداف الآتية: 1- تطوير إدارةوتنظيه الإشراف العلمي بـالجامعات المصرية، والتشريعات المنظمة له إداريًا وماليًا.

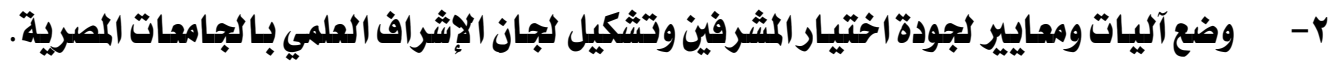

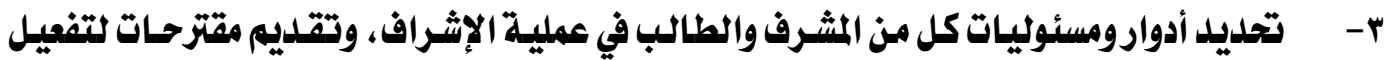

$$
\text { وتخسين القيام بها على أكمل وجه. }
$$

ع- إرساء دعائم وأسس وضوابط لتنظيبم العلاقة الإثرافية بين الأستاذ المشرف والطالب الباحث.

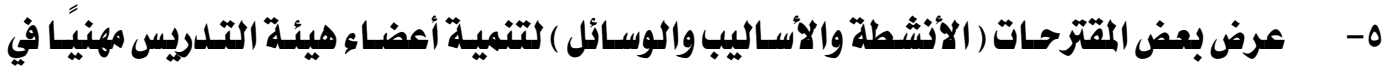
مجال الإشراف العلمي. ثالثًا : مصادربناء الرؤية المقتز حة: تم الاعتماد في بناء الرؤية المقترحة على مجموعة من المصادر، هي: الإئ

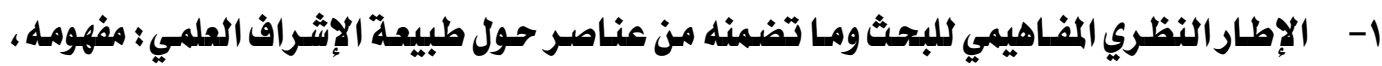

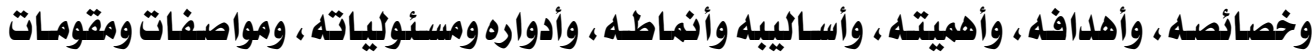

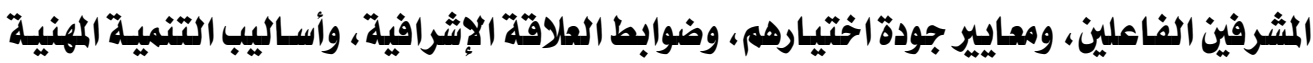

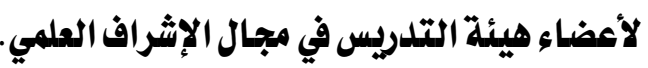

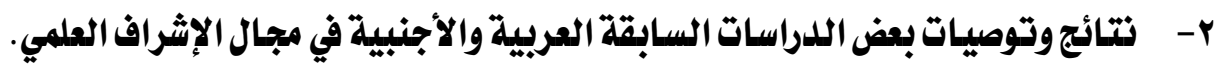

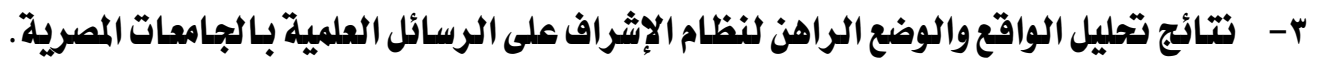

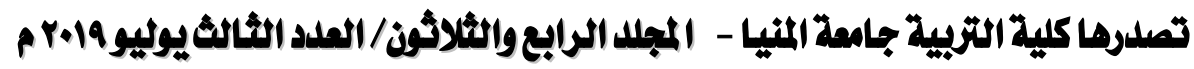
gamel_abdo59@yahoo.com

http://ms.minia.edu.eg/edu/journal.aspx 


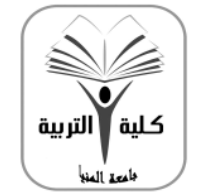

$$
\text { مجالة البحث في التربية ومام الثنسن }
$$

كلية مُقتملة من الميئة القومية لضمان جودة التمبيم

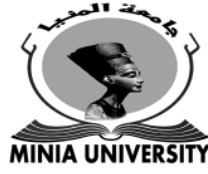

ع- خبرات بعض الجامعات الأجنبية ( موضع المقارنة ) في مجال الإشراف العلمي، ونتائج التحليل المقارن

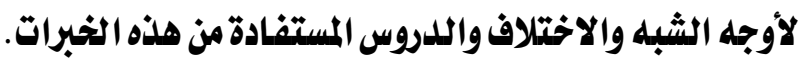

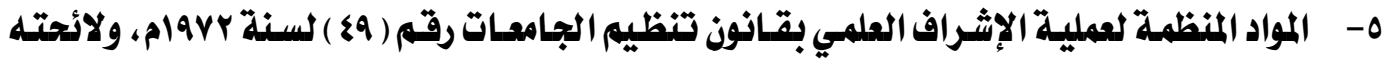

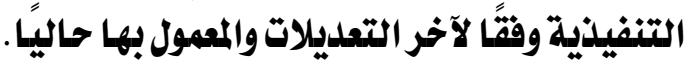

1 - اللوائح الداخلية للدراسـات العليـا لبعض الجامعات المصرية والعربية والأجنبية فيما يخص إدارة

$$
\text { وتنظييم الإشراف على الرسائل العلمية. }
$$

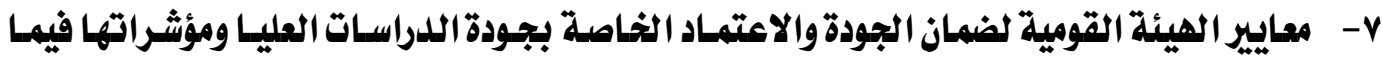

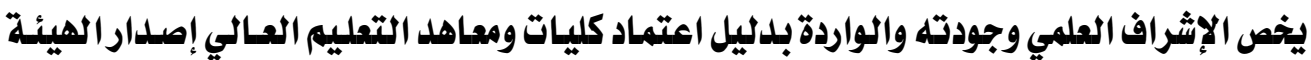

$.6 r+10$

رابعًا : محاوروأبعاد الرؤلية المقترحة:

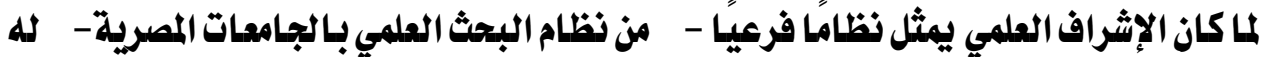
مجموعة من العناصر والأركان ( المشرف أو لجنة الإشراف، الباحث، وأدوارومسئوليات وحقوق وواجبات كلٍ منهما، والتشريعات المنظمة للإثراف العلمي إدرايًا وفنيًا وماليًا، والعلاقة الإشرافية بين الأستاذ والطالب وضوابطها، وأنشطة التنمية المهنية للمشرفين )، وفي ضوء ما أسفر عنه تحليل الواقع والوضع الراهن لهذه العناصر، والتحليل المقارن لخبرات الجامعات الأجنبية في مجال الإثراف العلمي، فإن الرؤية المقترحة للتطوير تتضمن أبعاد وعناصر هذه النظام ومقترحات وإجراءات لتطوير كل بعد، وذلك

$$
\text { على النحو الآتي: }
$$

أوثًا : مقتر حات خاصة بتطوير إدارة الإشراف العلمي وتشريعاته المنظمة بـالجامعات المصرية: وتشمل مجموعة من المقترحات التي قد تسهم في تطوير إدارة وتنظيم الإثراف على الرسائل

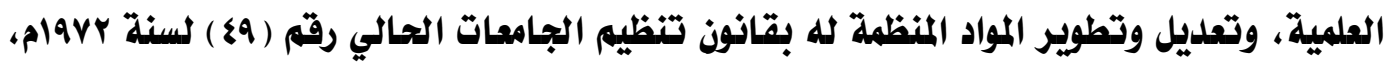
وتطوير اللوائح اللاخلية للدراسات العليا بكليات التربية فيما يخص الإثراف العلمي على طلابها

$$
\text { ورسائلهم العلمية، وتتمثل هذه المقترحات في: }
$$

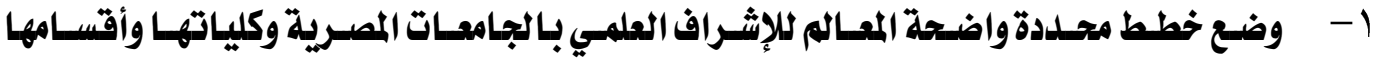
المختلفة، تتتلاءم مع طبيعة كل جامعة وتخصصات كلياتها وأقسامها، وعلد أعضاء هيئة التدريس 
بـالكليـات والأقسـام وأحمـالهم التدريسية والإداريـة والإثـرافية، وفي ضـوئها يـتم قبـول العـدد المناسب من البـاحثين المقبلين على القيلـ والتسجيل، والعمل على تطوير هـذه الخطة وتحليثها سنويسا أو كلما دعث الحاجة للذلك.

Y- وضع رؤية ورسسالة وأهداف وأدوارومسئوليات واضحة للإثراف العلمي بـالجامعات المصرية على مستوى كلياتها وأقسامها العلمية، ومراجعتها بشكل دوري لتعبر عن الصورة المرغوبة والمأمولة من

$$
\text { الإشراف العلمي. }
$$

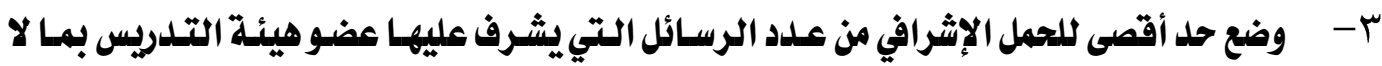

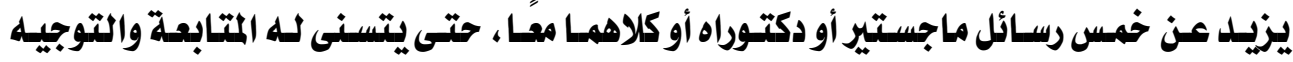
والإرشاد في ظل أعبائه التدريسية والإدارية والمجتمعية وغيرها. ع- - احتساب الرسائل العلمية المتميزة التي يشرف عليها عضو هيئة التدريس ضمن أعمال الترقية وتقيمها بوزن مستقل بعيلًا عز ملف أنشطته في ضوء جودتها وليس عددها.

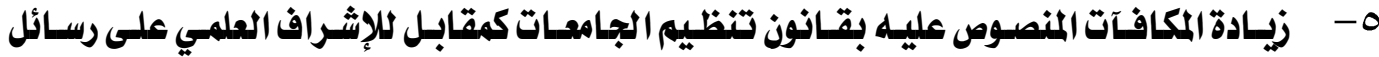

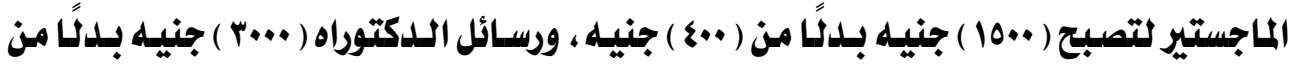

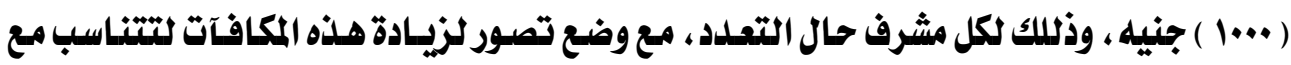

$$
\text { الجهلد والوقت المبذول في عملية الإثراف. }
$$
Y- تتولى جهة رسمية عليا يُمثل فيها أساتدة الجامعات وكلياتها بتخصصساتها المختلفة مهمة إعـادة النظر وفحص ومراجعة وتعديل المواد المنظمة للإثراف العلمي - إداريًا وماليًا- بقانوز تنظيم الجامعات الحالي في ضوء طبيعة كل تخصص علمي.

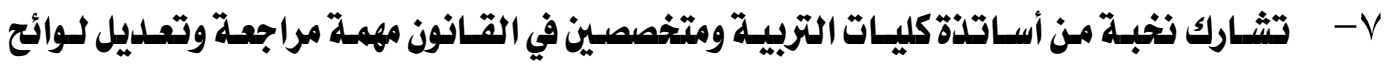
اللدراسات العليا بالجامعات المصرية وخاصة المواد المنظمة للإثراف العلمي في ضوي معسايير جودة عالمية وعربية، وتضمينها مواد وقواعد تنظم العلاقة الإثرافية بـين الأستاذ المثرف والطلاب الباحث، وتحلد مسئوليات وأدواركل منهما في عمليـة الإثراف، وتسمح بسهولة ويسر للباحث بتفيير المشرف عند وجود صعوبـات ومشكلات وعلدم تفاهم يعيق استكمال المشوار البحثي، أو لسفر $\varepsilon \wedge r$

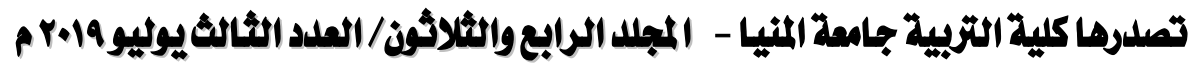
gamel_abdo59@yahoo.com

http://ms.minia.edu.eg/edu/journal.aspx 


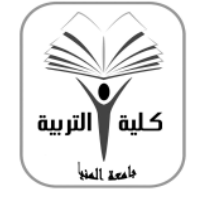

$$
\text { مجلة البعث في التربية وعلم النفس التربية - جامعة المنيا }
$$

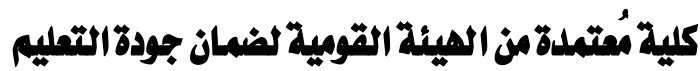

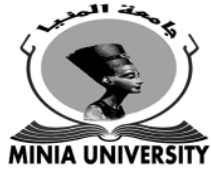

أو إعارة أو ابتعاث أو مرض أو وفاة أحدا الشرفين... إلخ.

1- تضمين قانون تنظيه الجامعات ولوائح الدراسـات العليا موادًا تنص على معايير علمية لاختيسار الشرفين على الرسائل العلمية، وآليـات وإجراءات واضحة لتشكيل لجسان الإثراف، مع بيـان دور

المجالس الرسمية ( القسم، الكلية، الجامعة ) في هذا الاختياروالتشكيل.

9- السماح بتفيير المشرف وفق إجراءات علمية وإدارية واضحة محلدة وميسرة إذا تبين أن الاختيـار

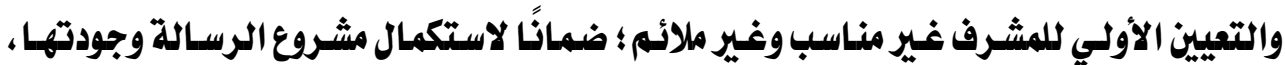
وحفاظًا على سلامة العلاقة الإشرافية بين الأستاذ والطالب. • 1- تففيل الأخذل برغبة الباحث في اختيسار مشرفه والعكس، وتضمينها كمسادة في لـوائح الدراسـات

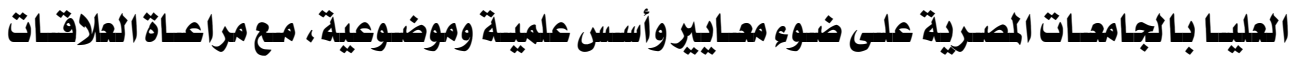
الإنسانية وعلدم تضارب المصالج بين الشرفين والطلاب ؛ ضمانًا لجودة الرسائل العلمية المنتجة.

ثانيًا : مقترحات خاصة بتطوير معايير اختيار الشرفينوتشكيل لجحان الإثراف على الرسائل العلميية: عملية الإشراف العلمي عملية صعبة مُعقدة، وتتطلب مشرفًا ذا مواصفات وخصائص علمية وتفسية واجتماعية، ومن ثم ينبفي مراجعة آليات ومعايير اختيار المشرف العلمي وتشكيل لجان الإثراف الثراف العلمي في ضوء تلكك المواصفات والخصائص ومعايير الجودة، ويقدم هذا المحور مجموعة من الخصائص والمواصفات التي ينبفي توافرها في الشرف العلمي، وقائمة من المعايير ينبفي أن يتم في ضوئها اختيار وتشكيل لجان الإثراف العلمي، وذلك على النحو الآتي : 1- خصائصومواصفات المشرف العلمي: لكي يقوم المشرف العلمي بلدور فغال في العملية الإثرافية، وتتصف ممارساته بالجودة العالية،

$$
\text { ينبغي أن تتوافر فيه المواصفات وا لخصائص الآتية: }
$$
- الخصائص والمواصفات العلمية: وتتمثل في القدرة على التفكير العلمي والناقـل والإبـلاعي، الإلمام بتوجهات البحوث العلمية الحليثة في مجال تخصص، وسعة الاطلاع، الموضوعية والتمكن العلمي والبحثي، الإنتاجية العلمية المتيزة والمستمرة، الخبرة في مجال البحث والإثراف العلمي، الحرص البحص

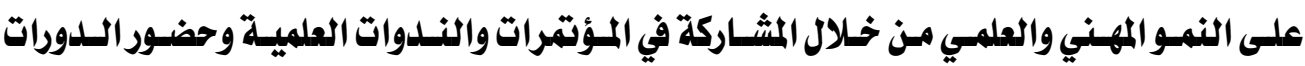
$\varepsilon \wedge \varepsilon$

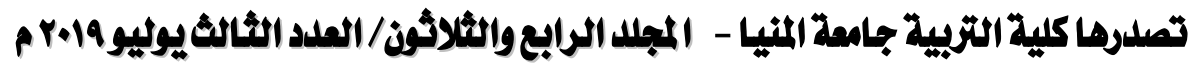
gamel_abdo59@yahoo.com

http://ms.minia.edu.eg/edu/journal.aspx 
الخصائص والمواصفات الأخلاقية : أن يكوز المشـرف قلدوة خُلقية، ذا سعمة مهنية وأخلاقية طيبـة، لليه القدرة والصبر وسعة الصدر في الاستماع للباحثين ومساعدتهم وتوجيههم مراعيـا لأخلاقيـات

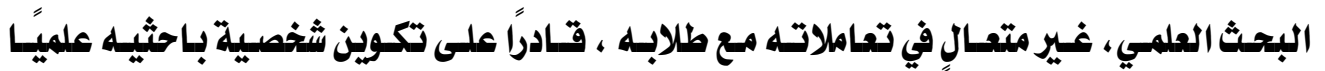
وأخلاقيًا وثتافيًا واجتماعيًا. الخصائصو المواصفات النفسية : أن يكون الشرف متزنًا انفماليًا وعاطفيـا، يمتلك غضبه ويكظم

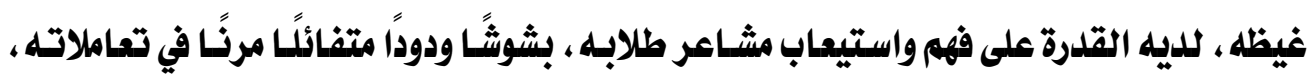
للديه الثقة في نقسه ويستطيع غرسها في طلابه.

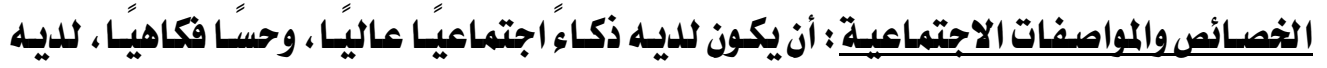
القدرة على الصبر والتحمل والجللد، واحترام طلابه وعلدم استفلانهم أو تسفيه آرائهم، والعلدالة والتعامـل بإيجابيـة معهـه، ومشـاركتهم منـاسـبـاتهم الاجتماعيـة أفراحهم وأحسزانهم، ويتعـرف ظروفهم، ويتقبل أعذارهم الملحة والضرورية. ومن ثم تستقيه بينهما العلاقة الإثرافية العلمية والإنسانية والاجتماعية والمهنية وتستمر حتى بعد الانتهاء من المشروع البحثي. r - معايِير جودة اختيـار المشرف وتشكيل لجحان الإشراف العلمي؛ وإحمانًا تتمثل معايير اختياروتشكيل لجان الإثراف على الرسائل العلمية في: أن يكوز المشرف قدوة خُلقية وعلمية، وذا سمعة بحثية وإشرافية طيبة. أن يكون التخصص ( العام والدقيق ) للمشرف وثيق الصلة بمجال وموضوعات الرسائل العلمية التي سيشرف عليها. • أن يكوز للمشرف أبحاث منشـورة في مجـال التخصص، وحضر بعض المؤتقرات العلمية أو النـلدوات واللدورات ورش العمل لموضوعات في مجال التخصص أو الإشراف العلمي. أن توضع رغبة الباحث في الاعتبار عند اختياروتعيين المشرفيز على رسالته. أن ترك مساحة من الحرية للمشرف لاختيار طلابه. أن يكوز المشرف على علم وبصيرة بقواعلد الإثراف وممارسـاته ومسئولياته وأسـاليبه الحليثة، $\varepsilon \wedge 0$

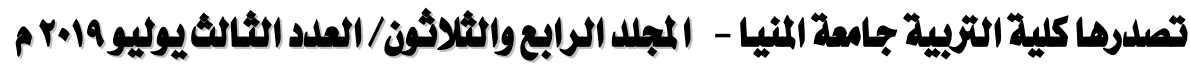
gamel_abdo59@yahoo.com

http://ms.minia.edu.eg/edu/journal.aspx 


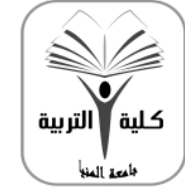

$$
\text { مجلة البعث في التزبية وعلم النفس }
$$

كلية مُعتملة من الهيئة القومية لضمان جودة التعليم

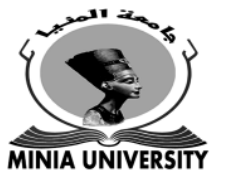

$$
\text { وقادرًا على ممارسة أدواره ومهامه الإشرافية بشكل فعال. }
$$

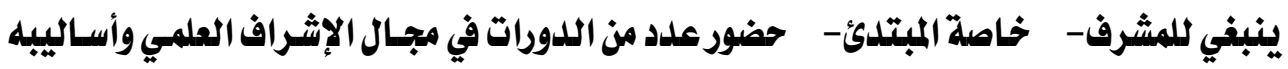
واتجاهاته الحليثة، اختياريًا ومجانيًا.

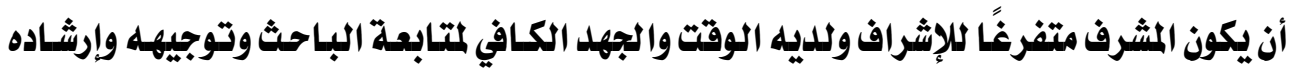
وتقويمه ، وتقديم خدمة وخبرة تعليمية وبحثية وإشرافية جيدة للباحث. لا ينبفي تعيين أستاذًا من خارج الجامعة أو الكلية كمرف رئيس على الباحث، ولكن يمكن اختياره

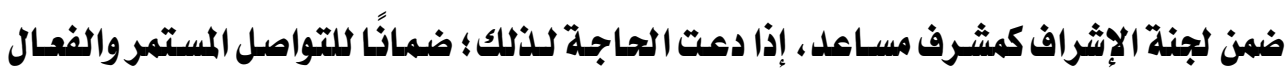

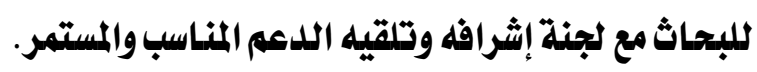

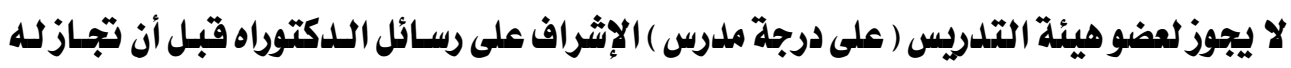

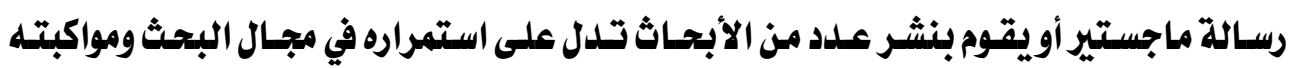
لمتفيرات في مجال تخصصه. وضع حلدود مقنتة لإثراف عضو هيئة التدريس ( ملرسى، أستاذ مسـاعل ) عامل أو متفرغ ومر على تعيينه بالدرجة أكثر من سبع سنوات ولم يتقدم للترقية للدرجة التالية على على الرسائل العلمية بمانيا

$$
\text { يخدم البحث العلمي وجودة الإثراف. }
$$

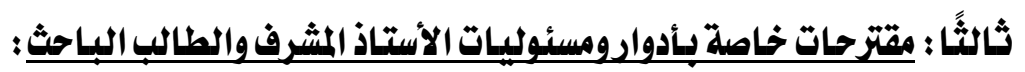

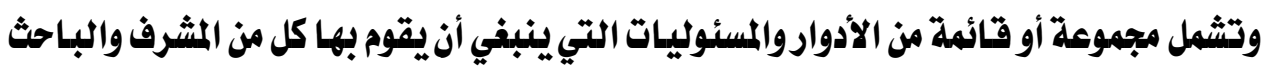
خلال العملية الإثرافية من أجل إنجاز الرسالة العلمية على الوجه المأمول، وتتمثل تلك الأدوار

$$
\text { والمسئوليات في الآتي: تلإلية }
$$

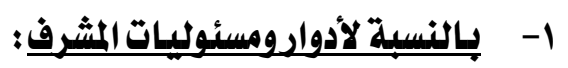

المشرف العلمي هو الموجه والمرثلد والميسر والمعلم ...إلخ، من أدوارومسئوليات ينبفي على المشرف

القيام بها على أكمل وجه، وتصنف أدوار ومسئوليات الشرف إلى أدوار ومسئوليات علمية أكاديمية،

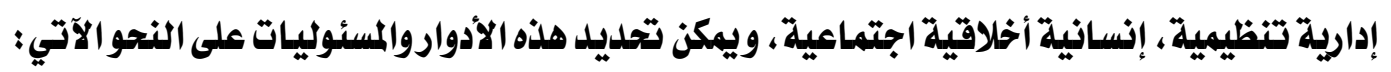

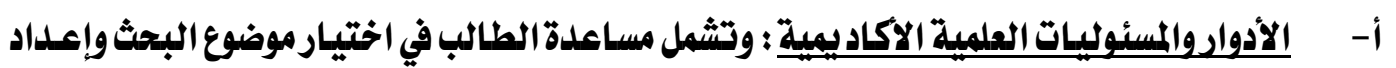
$\varepsilon \wedge 7$

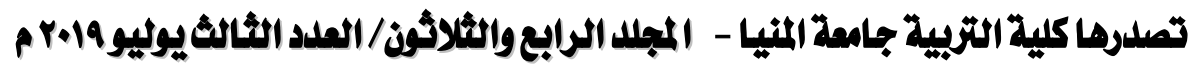
gamel_abdo59@yahoo.com

http://ms.minia.edu.eg/edu/journal.aspx 
الخطة، وتوجيه الطالب إلى الأدبيات ومصادر المعرفة ذات الصلة بموضوع بحثيه، وتنمية قدرات ومهـارات الطالب البحثيـة، ومسـاعدته في اختيـار مراجـع بحثـه ، وكيفيـة كتابتهـا وتوثيقهـا، وإرشــاده إلى طـرق وأدوات جمـع لمعلومسات والبيانـات وتصـنيفها وتبويبهـا، تدريبـه على كيفيـة إعدادها وتطبيقها ومعالجة نتائجها إحصائيًا، وكيفية عرض وتحليل ومناقثة وتفسير نتائجها، ومراجعة وتقييم ما يكتبه الطالب بشكل نقدي وإعطائه تفلية راجعة أولًا بأول، ومتابعة تقدمه في البحث، ومسـاعدته في تنظيه وكتابـة تقريـر البحث وإخراجهـ في شكله النهـائي، ثم تهيئة الطالب للمناقشة والفحص، والـدافع عن آرائه الصـائبة أثثاء المناقشة، والإثراف على إجراء تعديلات لجنة المناقشة والحكم، ثم إخراج الرسالة في شكلها النهائي وطباعتها.

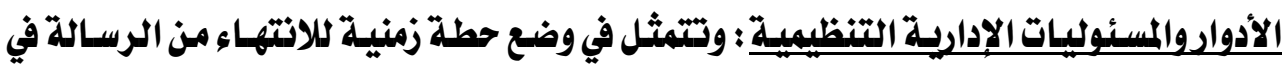
الوقت المحلد، وتحليل اللقاءات الإثرافية، وضع جلول زمني لها بما يتناسب مع طرفي الإثراف،

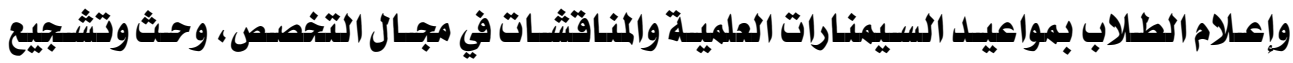
الطالاب على حضورها للاستفادة ومتابعة حضورهم، وتدوين الملاحظات ومناقشة الطلاب حولهـا، وإعلام الطلاب بـالأمور الإداريـة المتعلقة بـالإثراف وإعداد الرسـالة وتطبيق أدواتها وخطابـات

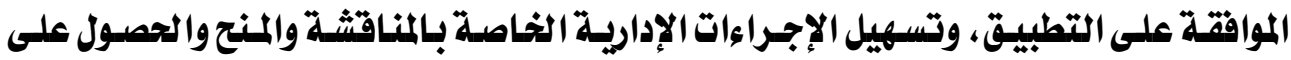
اللدرجة العلمية، ومتابعتها في المجالس الرسمية حتى يمنح الطالب الدرجة العلمية أو يُعين إن كان ضمن الهيئة المعاونة.

ج- الأدوادوالمسئوليـات الأخلاقيـة : وتشــل إكسـاب الطـلاب لأخلاقيـات البحث العلمي من الأمانـة

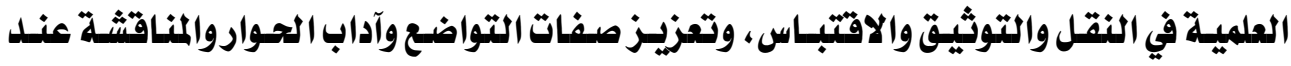
طلابه، تلدريب الطلاب على المرونة الفكرية وعلدم التعصب لآرائهم، وأن يكوز المشرف قدوة حسنة في البحث العلمي وأخلاقياته ، وأن يوجه طلابه للاقتماء بـالنماذج البحثية المتميزة.

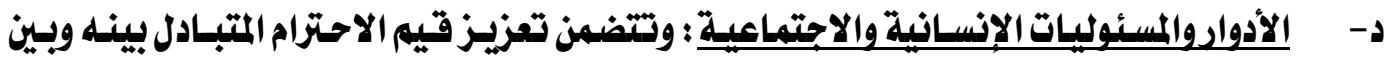
طلابـه ، وتقديم يـلـ العـوز والمسـاعدة لهم، احترام وجهـات نظر وآراء طلابـه وعـدم التقليل من شأنهم أو تسفيههم، تحفيز الطلاب وتشجيعهم وتقوية ثثتهم بـأنفسهم، وتلدليل الصعوبـات التي « ^

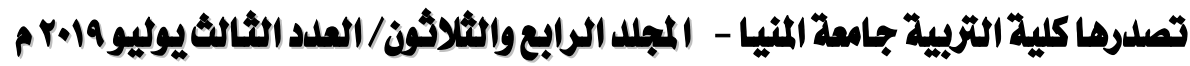
gamel_abdo59@yahoo.com

http://ms.minia.edu.eg/edu/journal.aspx 


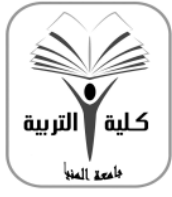

$$
\text { مجالة البجث في التزبية ومالم النفس }
$$

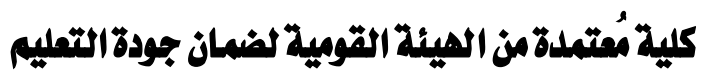

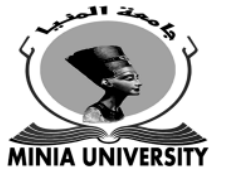

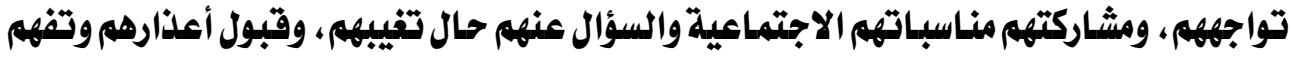
ظروفهم الخاصة، ومساعلدتهم على تخطي الصعاب في البحث وفي الحياة الاجتماعية، والالتزام بهواعيد اللقائات الإثر افية معهم، والحرص على إفادتهم ونفههم.

وإحماثًا تتمثل أدوادومسئوليـات المشرف العلمي ( أكاديميًا وإداريًا وأخلاقيًّا ) في الآتي: - الالتزام وتحمل مسئولية توجيه الباحث ومساعلدته وإرثـاده فيمـا يتعلق بمراحل وإجراءات بحثله ، وأيضًا تعريفه بالسياسات والإجراءات واللوائح المنظمة للبحث العلمي والإثراف بـالجامعة والكلية

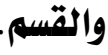
- يكون المشرف قدوة للباحث في الالتزام بـأخلاقيـات البحث والإثراف العلمي وسلوكيات التعامل مع الزهلاء الباحثين، والمحافظة على حقوق الملكية الفكرية، وتعزيز وتعميق الأمانة العلمية لدى طلابهـ مز خلال ممارساته البحثية. - يكون على دراية وخبرة بـالممارسـات الإثرافية والاتجاهـات والأسـاليب الحديثة في الإثراف العلمي، ويطبق منها ما يتناسب وطبيعة الطالب الباحث. - وضع جدول زمني للقاءات الإثرافية لإنجاز الرسـالة، والتوافق حوله والالتـزام بـه من قبل طرفي عملية الإشراف ( الأستاذ والباحث ). - توعية الباحث بعصادر اللدعم والتسهيلات والموارد البحثية ( مالية ومادية ) التي توفرهـا لـه جامعته وكليته للدعمه وتقكينه من إنجاز رسالته. - تحفيزوتشجيع الباحثين لمواصلة عملهم البحثي وإنجاز رسائلهم العلمية في الوقت المحلد وعلى الوجه

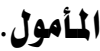
- الالتزام بمواعيد اللقاءات البحثية والإثرافية بصورة منتظمة؛ لتقديم اللدعم والمشورةوالتوجيه ، والاطمئنان على خط سير العمل البحثي ومستوى تقدم الباحث. - التأكلد من تطبيق الباحث لمنهجية بحثله بطريقة مُحكمة صحيحة، والتأكلد من صحة وسلامة النتـائج التي توصل إليها. - إعداد سجل خاص بالباحث توثق فيه نتائج اللقاءات الإثرافية، ومـا أنجزه الباحث ومستوى تقدمهـ $\varepsilon \wedge \wedge$

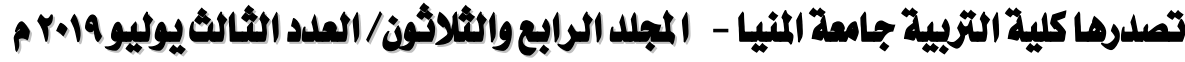
gamel_abdo59@yahoo.com http://ms.minia.edu.eg/edu/journal.aspx 


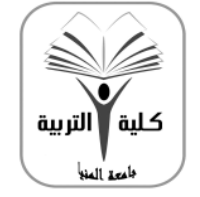

$$
\text { مجلة البعث في التربية وعلم النفس التربية - جامعة المنيا }
$$

كلية مُتملدة من الهيئة القومية لشمان جودة التعليم

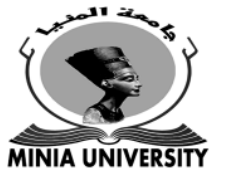

في بجثه.

- كتابة تقارير دورية ( شهرية وربع سنوية ونصف سنوية وسنوية ) عن مستوى تقدم الباحث في رسالته ملتزمًا الموضوعية والصدق ودون مزايلدة في كل الأحوال التقدم في البحث أو البطئ. - وضع معايير لضمان صلاحية وقبول التقرير النهائي لبحث الطالب.

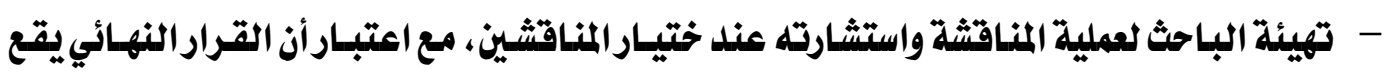
على عاتق لجنة الإثراف ثم مجلس القسه. - تسهيل الإجراءات الإدارية لاتقام المناقشة في موعد محدد بالتنسيق مع الباحث والمناقشين، تلدريب الباحث على التعامل بشكل مناسب مع المراجعة النقدية للمناقشين أو المتحدين. - الدفاع عن أفكار الباحث الصحيحة أمام لجنة المناقشة، والإثادة بمجهوده ودوره إن كان للباحث ذلك. - متابعة إجراء الباحث لتعديلات لجنة المناقثة والحكم على الرسالة، وتقليم ما يفيل إجراء الباحث لها ؛ من أجل استكمال إجراءات منح الدرجة العلمية.

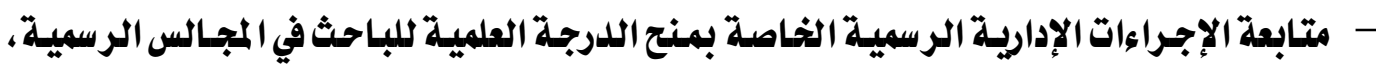
حتى صلور قرار منح الباحث الدرجة العلمية. r ب - بالنسبة لأدوارومسئوليات الطالب البياحث:

يمثل الطالب الباحث عنصراً أساسيًا في منظومة الدراسات العليا والبحث العلمي، والطرف الأول البأول

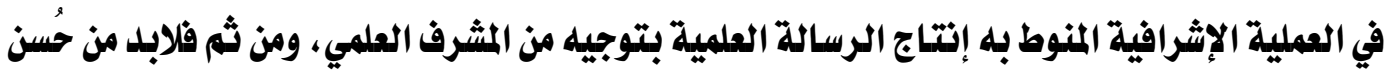
اختياره وإعداده في ضوء معايير الجودة والجدارة والاستحقاق من حيث الكفاءة العليية والأخلاقية، وأن

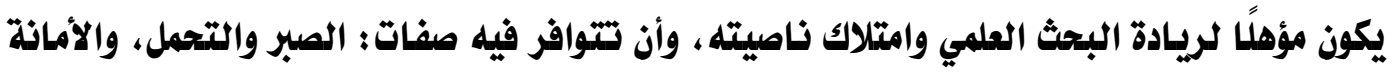
العلية، والموضوعية والنزاهة العلمية، المرونة الفكرية، ومهارات التفكير العلمي بأنواعه المختلفة، وحب الاطلاع، واتقان مهارات البحث العلمي والحاسوب واللفة الإنجليزية؛ حتى يستطيع القيام بأدواره ومسئولياته، وتتمثل أهم أدوار ومسئوليات الباحث خلال العملية الإشرافية ومراحل البحث لإنجان

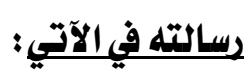
- تحمل المسئولية الشتركة مع الشـرف في إنجـاز الرسـالة في الوقت المحلد طبقًا للجدول الزمني التتفق $\leqslant \wedge 9$

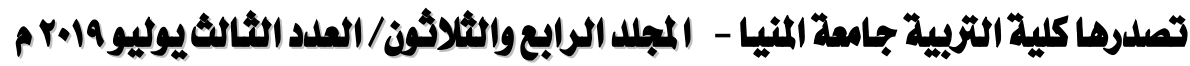
gamel_abdo59@yahoo.com

http://ms.minia.edu.eg/edu/journal.aspx 


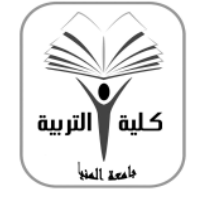

$$
\text { كجالة البحث في التزبية وملم النفسل }
$$

كاليلة مُتملدة من الميئة القومية لضمان جودةالتمليم

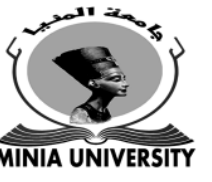

$$
\text { عليه. }
$$

- المعرفة الكافية بـاللوائح والقـوانين الـتي تنظم البحث العلمي والإثـراف بجامعته وكليته وقسهـه العلمي.

- الحفاظ على التواصل المنتظم مع مشرفه خلال اللقاءات الإشرافية، ووقت ما تدعو الضـرورة للتواصل والاستشارة بـالتنسيق والاتفاق المسبق مع المشرف.

- الالتزام بـالجدول الزمني المحلد لإنجاز المهام والمراحل البحثية المختلفة حتى الحصول على الدرجـة

العلمية.

- - حضور المناقشات والسيمنارات العلمية الخاصة بقسمه وتخصصه ؛ للاستفادة منها في تنمية مهاراته البحثية، وربما يجد فيها إجابة لما يريد السؤال عنه.

- التواصل والحواروالمناقشة حول ما تم إنجازه مع مشرفه، وعرض آرائه في قالب من الأدب والاحترام

$$
\text { وبشكل علمي. }
$$

- بلدل أقصى جهد ممكن للتوفيق بين آرائه وآراء مشرفه أو مشرفينه حسال التعدد، وإجراء التعلديلات والملاحظات التي يشيروز إليها بعد مناقشتها واقتنناعه بها.

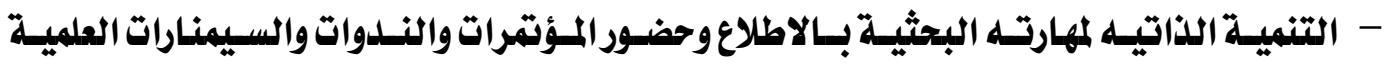
والتواصل مع الأساتذة والزهلاء من الجامعات والكليـات والأقسـام المنـاظرة عربيًا وأجنبيًا من خلال

التكنولوجيا التواصل الإكتروني عبر مواقع التواصل الاجتماعي ومواقع الجامعات على الإنترنت. - التقويم اللاتي لأدائه البحثي في ضوي الخطة الزمنية لإذجـاز الرسـالة والتي تم التوافق حولهـا مع مشرقه. - عند الانتهاء من تقرير الرسسايلة في الوقت المحلدد يسلمه للمشرفين وينتظر التفذيـة الراجعة، ثم يجري ما كان من ملاحظات بعد مناقشتها مع مشرفه. - يشارك المشرف في الإعداد لعملية المناقشة، وما يستتبعها من إجراءات : القيام بإجراء تعديلات لجنة المناقشة والحكم، وعرضها على المشرفين، ثم طباعة الرسيالة وتجليدها، والسير في إجراءات منح

$$
\text { اللدرجة العلمية حتى الحصول على اللدرجة. }
$$
$\varepsilon 9$.

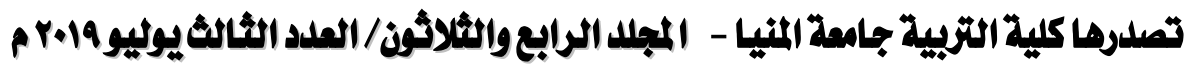
gamel_abdo59@yahoo.com

http://ms.minia.edu.eg/edu/journal.aspx 
رابعًا : مقترحات خاصة بتنظيبم العلاقة الإشرافية بين المشرف البياحث:

وتتضمن مجموعة من المقتزحات والإجراءات الخاصة بتكوين علاقة إشرافية علمية وإنسانية ونفسية واجتماعية مريحة ومتزنة بين الأستاذ المشرف والطالب الباحث قائمة على أسس ومبادئ وأخلاقيات المهنة والبحث والإثراف العلمي، بـالإضافة إلى آليات متابعة استمرارها على الطريق المستقيم، حتى يتم إنجاز رسالة علمية متميزة ذات قيمة نظرية وتطبيقة مُضافة، وتتمثل هذه

$$
\text { المقترحات والآليات في : الماتي }
$$

1- العمل على وضع مجموعة من القواعد العلمية والأخلاقية من قبل المختصين بـإدارة الدراسـات العليـا

$$
\text { بالجامعات والكليات ترسيم علاقة المشرف بالباحث وتسير في ضوئها. }
$$

ץ- إجراء تقييبم دوري من قبل إدارة الدراسات العليا بـالجامعات والكليات والأقسـام العلمية لاستقصساء آراء البـاحثين والمشرفين حسول طبيعة العلاقة الإثـرافية ومـلدى استقامتها أو إنحرافهـا والعوامل المؤثرة فيها، ومستوى الرضا عنها، والاستفادة من النتائج في عمليات التطوير والتحسين. ب- وضع ميثاق أخلاقي أو دليل إرشادي ينظم العلاقة الإشرافية بـين الباحث ومشرفه، يُحسد فيه أدوار واختصاصات ومهام كل منهما ، ويرسم حدود هذه العلاقة من حيث المسموح به وغير المسموح به خلال الإشراف والبحث. ع- - عقد اتفاقية أو مـا يمكن تسميته ( الإثراف بالتعاقد ) من خلال عقد مكتوب يتفق عليه كل من الثرف والباحث يتضمن أدوارومسئوليات كل منها، وحدود العلاقة بينهما، واللقاءات الإثرافية، ومصادر الدعم البحثي للطالب ... إلخ؛ مما يجعل للعلاقة الإثرافية حلدودًا وإطارًا مبني على الثقة والاحتزام المتبـادل. 0- المبادرة والسرعة في حل المشكلات التي قد تثشأ بين المشرفين على الباحث حال تعدد الإشراف أو بين الثشرفين والباحث جراء اختلاف وجهات النظر البحثية، والعمل على تهلئة الأجسواء دون الجور على حقوق البـاحث أو لجنـة الإثراف وذلك من خلال توسيط لجـان أخلاقيـات البحث العلمي والإثـراف

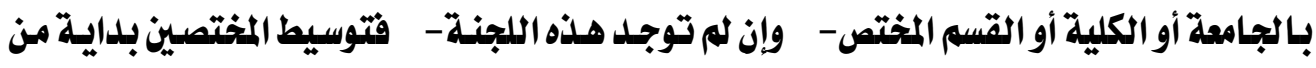
رئيس القسم وحتى رئيس الجامعة بحسب طبيعة المشكلات. 


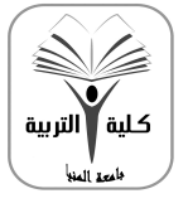

\author{
مجلة البعث في التزبية وعلم النفس \\ كلية التربية - جامعة المنيا
}

كلية مُتملدة من الهيئة القوميلة لشمان جودة التمليم

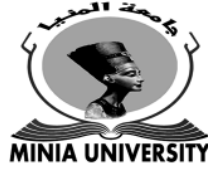

\- - وضع آليات من قبل إدارة الجامعة والكلية ووكيل الكلية المختص بالدراسات العليا والبحوث ورئيس

القسم العلمي لمتابعة حسن سير هذه العلاقة من بلاية الإثراف مروراً بمراحل البحث المختلفة حتى

إنجاز الرسالة ومنح اللدرجة العلمية.

وضع قواعد عامة يتم العمل بها بمجرد تسجيل الطلاب وبلدء العمل البحثي لتحقيق علاقة التواصل -V بين الباحثومشرف، منها : تحلديل وسائل اتصال وتواصل واضحة بين الباحث ومشرفه ووضع جـدول زمني للقاءات الإثرافية، وتبادل توقعات الدور البحثي بين المشرف والباحث، والتوجيه والإرشاد

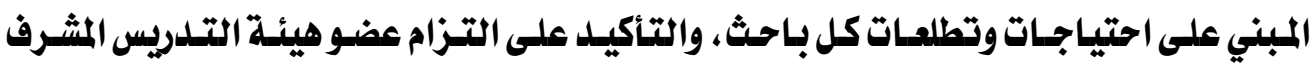
بالساعات المكتبية المخصصة لطلاب الماجستير والدكتوراه في جلدوله. ᄉ- وضع آليات من قبل إدارات الدراسات العليا بالجامعات تضمن حرية تعبير الباحث عن شعوره ووجهة نظره تجـاه العلاقة الإثرافية مع مشرفه في قالب من الدذوق والأدب وبصياغة عليية، من خلال استطالاعات الرأي وقياس مستوى الرضا عن العلاقة الإثرافية أسوة بالجامعات المتقدمة. 9- وضع آليات لتقليص علاقة القوة في العملية الإثرافية بمـا تعنيه من سيطرة الثرف والانصياع

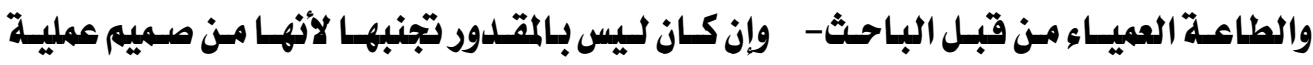
الإشراف- وذلك من خلال تطوير علاقات فعالة بـين المشرفوالباحث، وتشجيع الثرفين على إعطاء مساحة لبلاحثين للتعبير عن وجهات نظرهم، وتنمية روح الاستقلالية لديهم فيما يمكن إنجازه بلدوز تلدخل المرفين ولكن تحت متابعتهم وعلمهير.

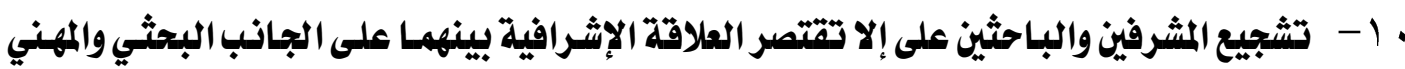
فحسب، بل ينبفي أن تشمل الجانب الاجتماعي والإنساني حتى بعل إنهاء العمل البحثي. 1) - تنمية الوازع الديني والقيه الأخلاقية التي تنظم علاقتات العمل وتلدعو للاحترام، وتعضيد قيه العلاقات الإنسانية بين الشرف والباحث، من خلال الندوات والمؤتمرات ... إلخ. خامسًا : مقتر حات خاصة بالتنمية المهنية لأعضاء هيئة التلدريس في مجال الإشراف العلمي: تضم هذه المقترحات مجموعة من الإجراءات والأنشطة والأساليب والوسائل للتنمية الههنية قد تسهم في تقليم التوجيه واللدم ورفع الكفاءة المهنية لأعضاء هيئة التدريس- خاصة الجدد والمبتدئين $\varepsilon 9 r$

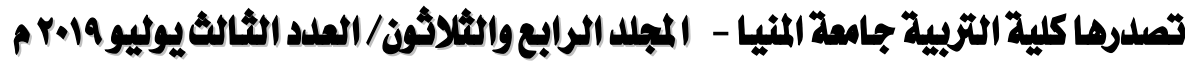
gamel_abd059@yahoo.com

http://ms.minia.edu.eg/edu/journal.aspx 
( الملدرسيز )- في مجال الإشراف العلمي؛ بما يساعدهم في تحسين أداء أدوارهم ومسئولياتهم الإشرافية، وتزويلدهم بـالمعارف والمعلومات والمهارات والخبرات حول طبيعة الإثراف العلمي وممارساته وأساليبه الحديثة، واللوائح والقوانيز المنظمة لها، وأخلاقياته، وكيفية التعامل مع الأنماط المختلفة للباحثين وأساليب دعمهم والإشراف عليهه، والوعي بالعوامل المؤثرة في عملية الإشراف، وطرائق التفلب على صعوبـاته ؛ وذلك من أجل تحقيق كفاية وفعالية الأداء الإشرافي ومشاركة الباحث في إخراج رسالة علمية رصينة ذات قيمة مضافة، وهذه المقترحات والإجراءات تثمثل في: ا- استطلاع آراء أعضاء هيئة التدريس المشرفين بشكل دوري من قبل قطاع الدراسات العليا بالجامعات وكلياتهـا، ومراكز تنميـة القدرت بهـذه الجامعـات حول احتيـاجساتهم التدريبية في مجـال البحث

$$
\text { والإشراف العلمي. }
$$

r- عقد مؤتثرات حول طبيعة الإشراف العلمي وأبعاده المختلفة واتجاهاته ، تكون فرصة لالتقاء وتجمع عـد كبير مـن أسـاتذة الجامعـات في التخصصسات المختلفة ؛ لـتلاقح الأفكاروالتجـارب الإثـرافية

$$
\text { وتبادل الخبرات في هذا المجال. }
$$

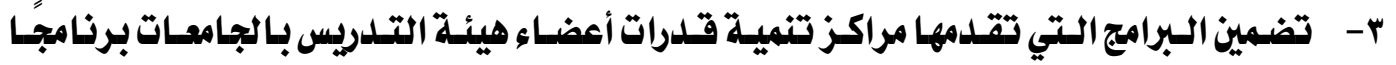
تدريبياً في مجال الإشراف العلمي، على أن يكون هذا البرنـامج اختيـارًا للأستاذ مسـاعلد والأستاذ، إجباريًا كمتطلب للتعيبي على درجة مدرس حيث تكوز الحاجة ماسة لما سيقدمه هذا البرنامج.

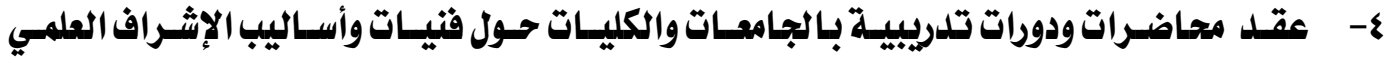
الحليثة، يحاضر ويلدرب فيها أساتلة مشهود لهم بـالكفائة البحثية والسمعة الإثرافية الناصعة،

$$
\text { ويكوز ذلك اختياريًا ومجانيًا. }
$$

0- عقد ندوات ورش عمل حول طبيعة الإشراف العلمي والأساليب والاتجاهات الحديثة في هـذا المجال، والتعريف بـالقوانين واللوائح المنظمة لعملية الإثراف العلمي، يحاضر فيها كبـار أسـاتذة التربية

$$
\text { مهن لهم بـاع وخبرة طويلة في مجال الإشراف العلمي. }
$$

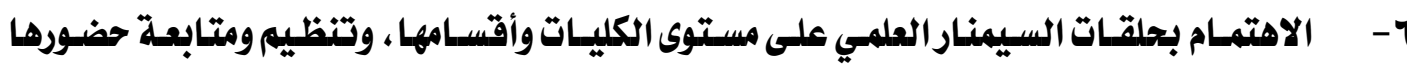
كوسيلة للتنمية المهنية لأعضاء هيئة التدريس وطلاب البحث العلمي، وعقد سيمنارات علمية خاصة 
لمناقشىلة مـا يستجدل في مجـال الإثـراف العلمي واتجاهاته وأسـاليبه الحليثة، وتفهـم أبعاده،

$$
\text { وتبادل الأفكاروالتجارب والخبرات. }
$$

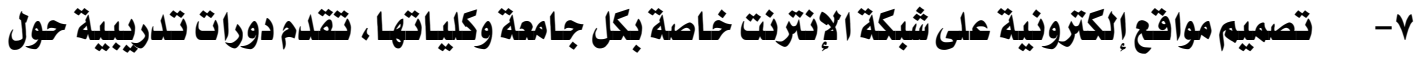
الإثراف العلمي وطبيعته، والتعريف بالقوانين واللوائح المنظمة لتشكيل لجسان الإثراف وإجراءات تفيير المشرفين في حالات السفر وغيرها، وكيفية حل المككلات وا لخلافات بـين المشرفين والبـاحثين، ويتضمن نماذج التقارير والخطابات والمكتابات الخاصة بمراحل الإشراف والبحث، وكيفية كتابـة تقـارير تقيييه أداء ومستوى البـاحثين والتقـلم في البحث، وعـرض الدراسـات العربيـة والأجنبيـة الخاصة بمجـال الإثـراف، وتقديم نصـائح لإثـراف الفعـال، ونمـاذج ناجحة ومتميـزة في عمليـة

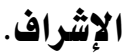

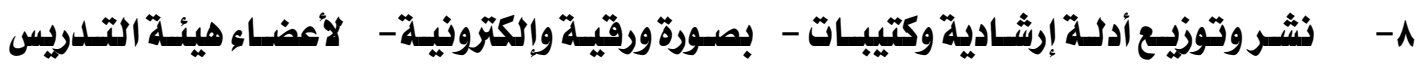
المشرفين وللطلاب الباحثين تقلدم معلومات حول عملية الإثراف والسياسات والقواعد المنظمة لها في الجامعة وكلياتها، وتكوز مهمة إعداد هذه الأدلـة لقطاع الدراسـات العليـا بـالجامعـات، كما يمكن إصلار دليل للإثراف العلمي الفعال يقوم على إعداده نخبة من أساتذة كل جامعة وكلياتها المختلفة. 9- القيـام بزيسارات تبـادل معرفي بـين أسـاتذة الجامعـات الاكفـاء ومن خلال المناقشـات العلميـة لنقل

خبراتهم الإثرافية إلى شباب أعضاء هيئة التدريس بتلك الكليات كأحلد أساليب التنمية المهنية. •- عقد لقاءات تعريفية من قبل قطاع الدراسات العليا بالجامعات والكليات لتنمية مهارات الجانب الإداري الخـاص بعمليـة الإثـراف العلمي وخاصـة مر حلـة مـا قبـل تطبيـق أدوات البحث والدراسـة الميلاينـة، ومـا تتطلبـه من خطابـات وإفـادات يقوم بهـا المشرف لتوجيه الباحث للمختصين الـذين

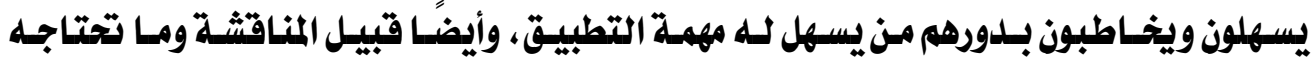
إجراءاتها من تقارير صلاحية الرسالة للمناقشة، وخطابات تثكيل لجنة المناقشة والحكم؛ ممـا قد يتطلب معرفة المشرف بنماذجها وصيفتها الإدارية وكيفية تعبئة هذه التقارير وا لخطابات وغير ذلك.

11- استقدام بعض الأسـاتذة الأجانب المتخصصين في مجـال التربيـة ؛ لإلقـاء محاضـرات وندوات حسول

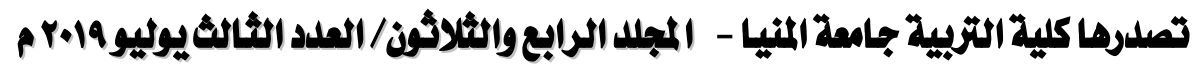
gamel_abdo59@yahoo.com

http://ms.minia.edu.eg/edu/journal.aspx 


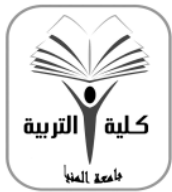

$$
\text { كجالة البعث في التزبية وملم النفس التزبية - جامعة المنيا }
$$

كالية مُتملةةمن الميية القومية لضمان جودة التمليم

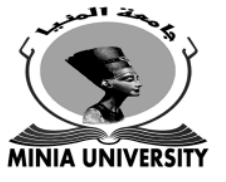

طبيعة الإثـراف العلمي وأبعاده، واتجاهاته الحليثة في الجامعـات الأجنبيـة المتقدمة، وكيفيـة

$$
\text { تقديم اللدمم للمشرفين والطالاب الباحثين. }
$$

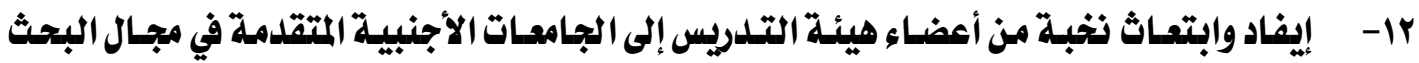
العلمي، للاطلاع على تجاربها ونظمهـا في الإثراف العلمي ومعـايير الجـودة العالية لهـذا المجـال، وأنشطة التنمية المهنية لأعضاء هيئة التدريس في مجال الإشراف العلمي.

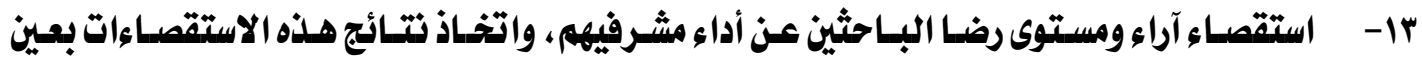
الاعتبـار، ووضـع بـرامج ودورات تدريبيـة لأعضساءهيئة التـدريس في ضـوائها ؛ بغيـة تحسين جـودة الإشراف والرسائل، والباحثين. 1 - عقد وررش عمل لتعريف المشرفين بأحدث الأساليب في التقيييم الدذاتي والتـأملي لأدائهم الإشرافي على طلاب اللدراسـات، والعوامل المؤثرة فيهه ، وتبـادل الأفكار حول تصـورات المشرفين عن طبيعة الإشراف العلمي والأنماط المختلفة للمشرفين، وأساليب الممارسات الذاتية التأملية للأداء الإشرافي. 10- تشجيع وتلدريب أعضاء هيئة التدريس على تنمية أنفسهم ذاتيًا في مجال الإثراف العلمي من خلال الاعتماد على الأساليب التكنولوجية الحليثة ومواقع التواصل الاجتمـاعي وغيرهـا، وتطويـع هـده الوسائل لخدمة عملية الإثراف في التواصل مع الباحثين والزهلاء المثتركين في الإثراف على الرسائل مز داخل الجامعة وخارجها. سادسا : توصيات عامة قد تسهم تحقيق الرؤلة المقتزحة: في ضوء ما أسفر عنه تحليل الوضع الراهن لنظام الإشراف العلمي بـالجامعات المصريله وما تم استخلاصه من أوجه ودورس مستفادة من خبرات الجامعات الأجنبية في هذا المجال، يوصي البحث بمجموعة من التوصيات العامة قد تسهم في تحقيق الرؤية المقترحة وأبعادها على أرض الواقع، وتتمثل أهم هذه التوصيات في: 1- الاهتمام بوضع معايير خاصة بجودة الإشراف على الرسائل العلمية ( معايير اختيار المشرفيز وتشكيل لجان الإثراف، أدوارومسئوليات الثشرف والباحث، ضوابط العلاقة الإشرافية....إلخ )، وتقوم بهلذه المهمة الهيئة القومية لضمان الجودةوالاعتماد وفي ضوي المعايير العالية لهذا المجال. $\leqslant 90$

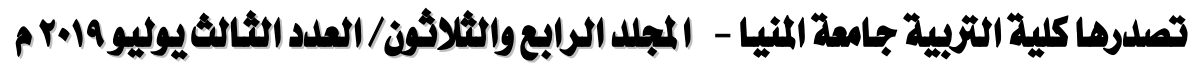
gamel_abdo59@yahoo.com http://ms.minia.edu.eg/edu/journal.aspx 
r- عقد لقاءات تعريفية في بلداية كل عام جامعي تجمع بين إدارة الدراسات العليا والمشرفين من أعضـاء

هيئهة التـلدريس وطـلاب اللدراسـات العليـا للتعريـف بـإجراءات البحث العلمي والإثـراف وطبيعته وإجراءاته وأدوارومسئوليات كل المشرف والباحث، وبحث ودراسة قضـايا ومشكلات الإثراف العلمي بالجامعة، والمشاركة في حلها ووضع رؤى التطوير والتحسين. r- العمل على تطوير الإطار التشريعي المنظم لعملية الإثراف العلمي بـالجامعات المصرية، واستحداث تشريعات جليدة من شأنها تطوير هذه العملية والارتقاء بمستواها فنيًا وإداريًا وماليًا. ؟- العمل على زيـادة والمكافآت المالية المخصصة للإثراف العلمي على رسـائل الماجستير والدكتوراه من الصناديق والوحدات ذات الطابع الخاص بـالجامعات والكليات للتناسب مع الجهود المبلذولة من قبل لجان الإثراف خلال مراحل البحث الصعبة، وأسوة بـالجامعات المتقدمة. 0- تفعيل دورقطـاع الدراسـات العليـا بـالجامعـات والكليـات في المتابعة والتقويم المستمر وعلى أسس علمية واضحة لكل ما يخص نظام الإثراف العلمي وطرق تعيين لجانه ، وملدى العدالة والالتزام بالنصاب الإثرافي لكل عضو هيئة تلدريس، ومتابعة مشكلات توتر العلاقتات الإثرافية بـين بعض المشرفين والباحثين والعمل على حلها. - - تبني قطاع الدراسات العليا بالجامعات المصرية وكلياتها قائمة من الأدواروالمسئوليات المحلددة ككل مـن المشرف والباحث يـتم التوافق عليهـا، ويـتم إعلانهـا والتوعيـة بهـا مـن قبـل المختصـين بالدراسـات العليـا، ويتم تضمينها بـاللوائح الداخلية للجامعـات والكليـات والأقسـام العلميلة، في ضوئها تتم المساءلة والمحاسبية لطرفي عملية الإشراف. V- - تشكيل لجـان لأخلاقيـات البحث العلمي والإثـراف وحقـوق الملكيـة الفكريـة والنشـر على مسـتوى الجامعة والكلية والقسه ؛ للفصل في النزاعات والمشكلات التي تواجه عملية الإثراف العلمي وتوتر العلاقة الإشرافية بين بعض المشرفين وباحثيهم. 1- وضع مجموعة من الضوابط والقواعل لتنظيم العلاقة الإشرافية بين المشرف والباحث، يـتم التوافق حولهـا، وتعلن من قبل الدراسـات العليـا بـالجامعات المصرية، ويتم تضمينها بـاللوائح الداخلية

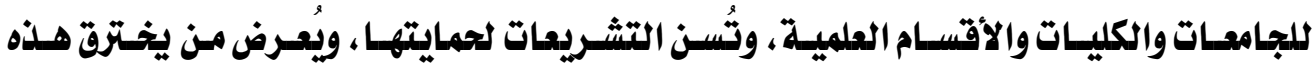
$\leqslant 97$

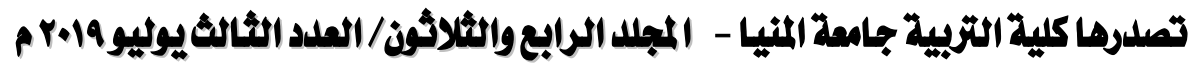
gamel_abdo59@yahoo.com

http://ms.minia.edu.eg/edu/journal.aspx 


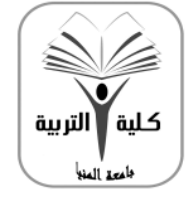

$$
\text { مجلة البهث في التربية وعلم النفسل }
$$

كالية مُشتمدة من الهيئة القومية لضمان جودةالتمايليم

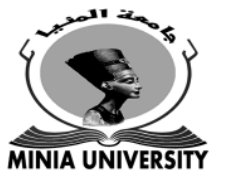

الضوابط للسساءلة القانونية.

9- الاستقصاء الدوري المستمر لآراء الباحثين والشرفين حول أداء كل منهما في عملية الإثراف، ومدى التزام كل منهما بأدوراه ومسئولياته، وتقتعه بحقوقه وأدائه لواجباته، والاستفادة من نتائج هلذه

الاستقصاءات كتفلية راجعة لتطوير الإثراف العلمي.

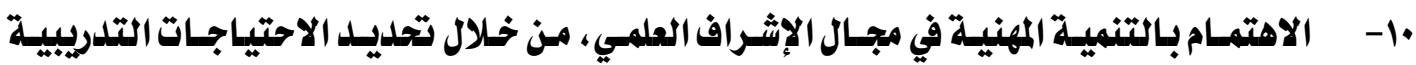

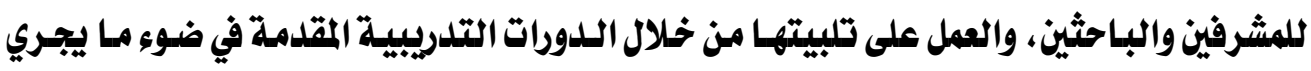

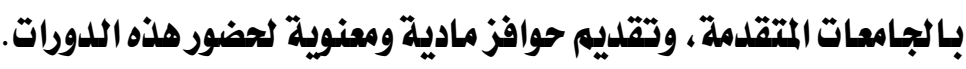
11- الاستفادة من التكنولوجيا الحليثة ووسائلها وتطبيقاتها في عمليات الإثراف الإلكتروني عن بعد، والتنمية المهنية لأعضاء هيئة التدريس والباحثين في مجال البحث والإشراف العلمي.

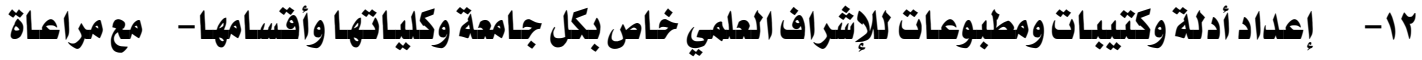
طبيعة التخصصات المختلفة- توضح طبيعة الإثراف العلمي وإجراءاته وأدوارومسئوليات المشرف والباحث وحقوق وواجبات كل منهما وحدود العلاقة الإشرفية بينها .. إلخ.

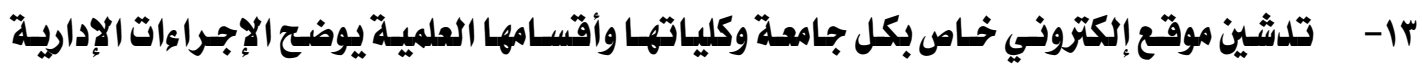
لملتسجيل والإثراف العلمي وحقوق وواجبـات المشرف والباحث، والتشريعات المنظمة لهذه العملية يتم متابعته وتحليثه باستمرار. 1ء- التقليل من الأعبـاء الإدارية والتدريسية لأعضاء هيئة التـدريس المشرفين على رسائل الماجستير

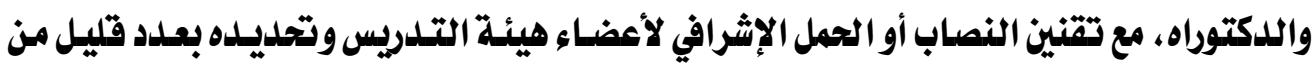

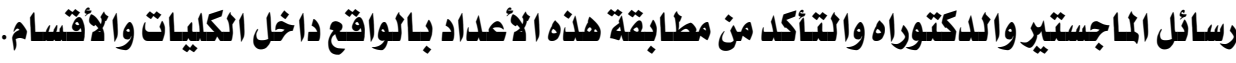

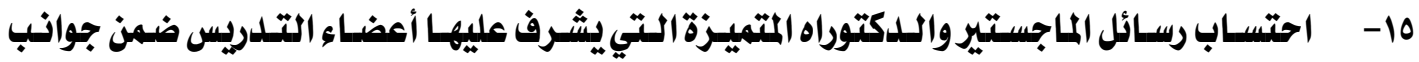

الترقية وإعطائها وزنًا نسبيًا أعلى ضمن أنشطة عضو هيئة التدريس البحثية في ضوء جودواتها. 17- تكثيف الدراسات والبحوث حول عملية الإثراف العلمي وطبيعتها وأبعادها ومشكلاتها، ومعايير جودتها، ودراسة الاتجاهات والأساليب وا لخبرات العالية للجامعات التتقدمة.

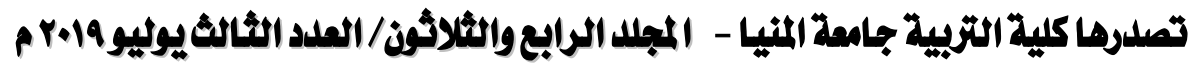
gamel_abdo59@yahoo.com http://ms.minia.edu.eg/edu/journal.aspx 
إن مجال الإثراف العلمي كمجال بجثي - ما زال - بحاجة لمزيلٍٍ من البحوث والدراسات التي تتناول تطويره في ضوء ما يستجد من اتجاهات وأساليب حديثة، ونظريات حول تفسير طبيعته وأبعاده، والعلاقة الإشرافية وأفضل الأساليب الإثرافية لإقامتها على أسس جيلة في ضوء العلاقات الإنسانية وأخلاقيات البحث العلمي، ومطالعة خبرات الجامعات الأجنبية والعربية المتقدمة ومقارنتها بخبرة الجامعات المصرية في هذا المال، ومز ثم يقترح البحث بعض الدراسات والبحوث المستقبلية في مجال الإثراف العلمي الرسائل الجامعية، منها : 1 - تصور مقترح لميثاق أخلاقي لإثشراف على الرسائل العلمية بـالجامعات المصرية. r- متطلبات تطبيق الإثراف العلمي الإلكتروني - من بعد- بـالجامعات المصرية في ضوي خـبرات بعض الجامعات الأجنبية.

ب - تصور مقترح لجودة الإثراف العلمي بكليات التربية المصرية في ضوي بعض الاتجاهات العالمية. ع - دراسة مقارنة لأساليب التنمية المهنية في مجال الإثراف الرسائل العلمية ببعض الجامعات الأجنبية، وإمكانية الاستفادة منها في مصر. 0- تطوير دور المشرف العلمي على الرسائل العلمية بـالجامعات المصرية في ضوء توجهات التحول الرقمي في البحث العلمي. צ- دراسة مقارنة لأنماط الإثراف العلمي السائدة بكليـات العلوم الإنسـانية وكليـات العلوم الطبيعية/ التطبيقية ببعض الجامعات المصرية.

V - دراسة تقويمية لدور لجان الإشراف على الرسائل العلمية بـالجامعات المصرية في ضوي معايير جـودة الدراسات العليا. م- توقعـات الـلدورفي عملية الإثراف العلمي بكليـات التربية في مصر "دراسة ميدانية من وجهة نظر الشرفين والطلاب" . 9- محـددات العلاقة الإثـرافية بـين أعضـاء هيئسة التـدريس المشـرفين والطلاب البـاحثين بـالجامعـات المصرية "دراسة تحليلية". $\varepsilon 9 \wedge$

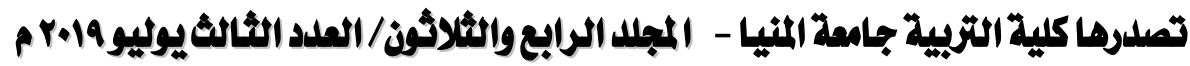
gamel_abdo59@yahoo.com http://ms.minia.edu.eg/edu/journal.aspx 


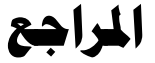

إبراهيه، مجدي عزيز (... r ) : موسومة المناهج التزبوية، القاهرة : مكتبة الأنجلو المصرية.

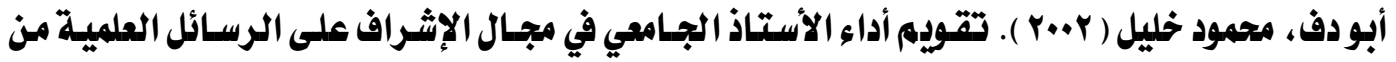
وجهـة نظـر طلبـة الدراسـات العليـا، مجلة القـراءةوالمعرفة، الجمعيـة المصـرية للقـراءة

$$
\text { والمعرفة، كلية التربية، جامعة عيز شمس، Vا، أكتوبر، 10- }
$$

أحمد، أحمد إبراهيي(10 (r) ). التزبية المقارنة ونظم التعليم من منظور إداري، الإسكندرية : دار الوفاء

$$
\text { للدنيا الطباعة والنشر. }
$$

أسعد، عبد الكريه حسان( • r ) . توقعات اللدور في عملية الإثراف البحثي، مجلة العلوم التزبوية، معهد الدراسات التربوية ( كلية الدرسات العليا للتربية حليثًا )، جامعة القاهرة، ه| ( 1 )، يناير،

$$
.01-r
$$

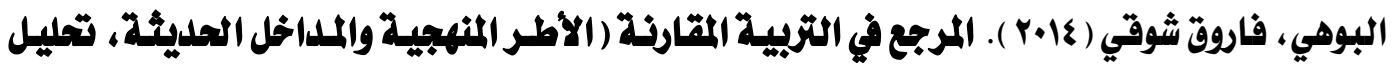
مقارن لنظم التعليم قبل الجامعي والجامعي )، الإسكندرية ؛ دار المعرفة الجامعية.

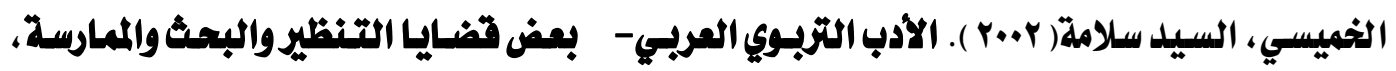
الإسكندرية : دار الوفاي لدنيا الطباعة والنشر.

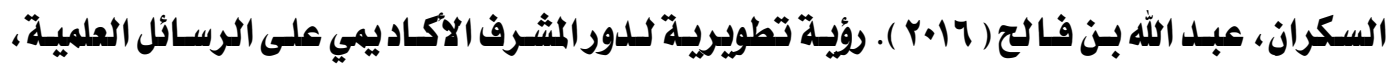
والبحوث التكميلية لطلاب اللدراسات العليا في أقسام التربية بجامعة الإمام محمدل بـن سعود

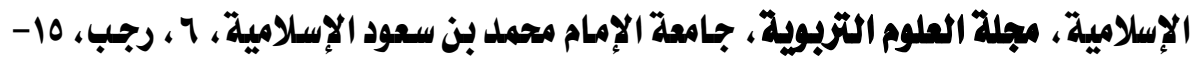
.$v 7$

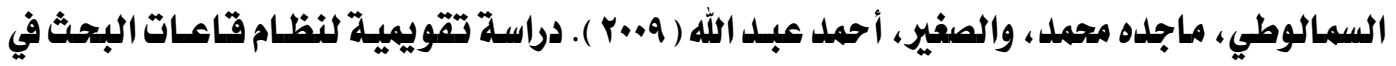
الأقسام التربوية بكليات التربية المصرية في ضوء آراء بعض أعضساء هيئة التـدريس وطلاب البحث، مجلة كلية التزبية، كلية التزبية، جامعة أسيوط، مصر ، هب ( 1 )، الجزيء الثـاني،

$$
\text { يناير ، ( ملخص البحث ). }
$$




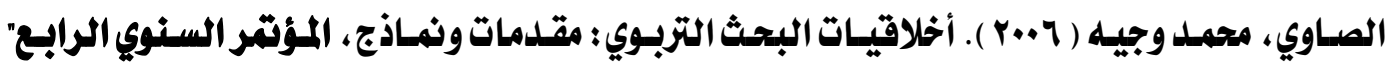

تطوير برامج كليات التزبية بالوطن العربي في ضوه المستجدات المحلية والعالمية"، ی- 9

فبراير، كلية التربية، جامعة الززقازيق.

الطوخي، هيثم محمد ( rامب ). التنمية المهنية لأعضاء هيئة التـدريس في مجال الإثراف البحثي، مجلة العلوم التزبوية، معهل الدراسـات التربويـة ( كلية اللدرسـات العليـا للتربية حاليـًا )، جامعـة

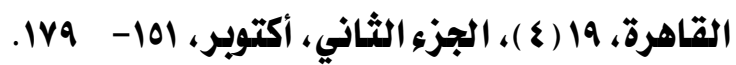

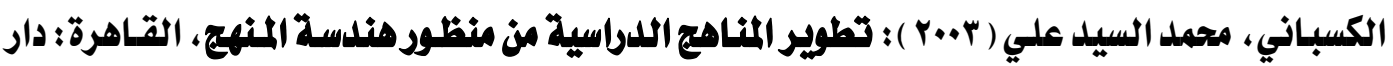

$$
\text { الفكر العربي. }
$$

الوحش، هالة مختار ( +•r ). مشكلات الإشراف العلمي على الرسائل الجامعية من وجهة نظر الباحثات

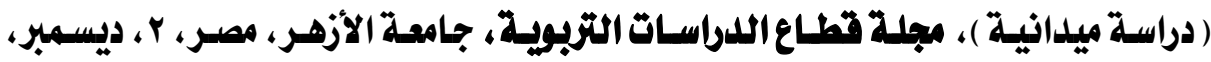

$$
. r \circ 9-r q r
$$

إيليفا، داود عبد القادر ( د. ت ). دور المشرف العلمي في الإثراف على الرسائل الاكاديمية : مبحث في منـاهج

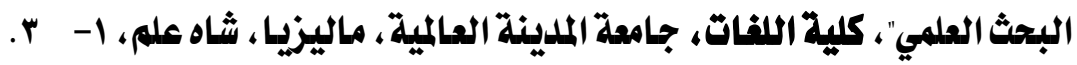

بخيت، صلاح الليز فرح، عوض، نائلة عمر، علي، أشرف محمد، والشـاعر، خليل يوسف ( (17 ). واقع

الإثـراف العلمي على رسـائل الماجسـير وأطساريح الـدكتوراه في علـم الـنفس بـالجامعـات

السودانية خلال خمس وعشروز ( عشرين ) عامًا، مجلة دراسـات عربية في التزبية وملم

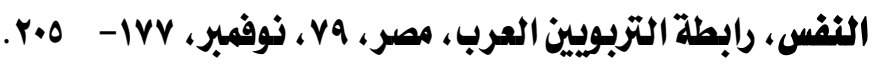

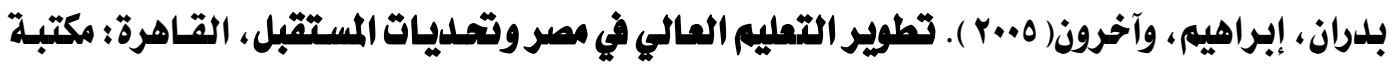

$$
\text { الشروق الدولية. }
$$

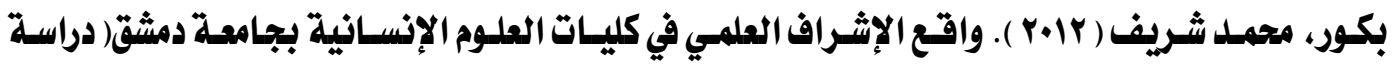

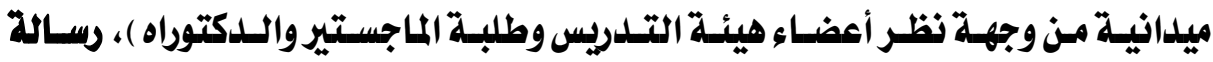
ماجستير غير منشورة، كلية التربية، جامعة دمشق، سوريا. بن هندي، عواطف بنت أحمد ( r.11 ). ضعف إعلداد الرسائل العلمية وسبل الحسد منها، الملتقي العلمي 


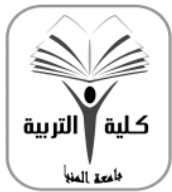

$$
\text { كجالة البحث في التربية ومالم النفس التزبية - جامعة المنيا }
$$

كالية مُتملةةمن الميية القومية لضمان جودة التمليم

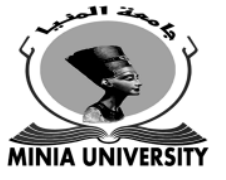

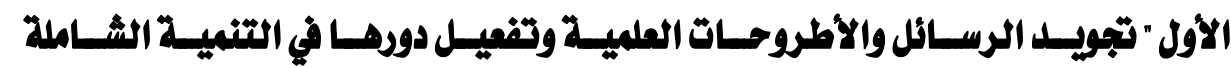

والمستلدامة"، • ا- ب أكتوبر، كلية الدراسات العليا، جامعة نايف العربية للعلوم الأمنية،

$$
\text { الرياض، السعودية. }
$$

توفيق، إبراهيه الدسوقي عوض الله ( با.r ) ـ. تطوير البحث العلمي بـالجامعات المصرية في ضوي متطلبات اقتصـاد المعرفة "رؤيلة مستقبلية"، رسـالة دكتوراه فير منشئورة، معهـد الدراسـات التربويـة

$$
\text { ( كلية اللدراسات العليا للتربية حاليًا )، جامعة القاهرة . }
$$

جامعة أسيوط، قطاع الدراسات العليا ( (19 ) : الإثشراف العلمي على الربسائل الجامعية، وتعبين لجهان

$$
\text { المكم عايها، متاح على: }
$$

http://www.aun.edu.eg/high_studies/taiin\%20ligan\%20el\%20hokm\%

$$
\text { , 29/3/2019.20ala\%20el\%20rasail.html }
$$

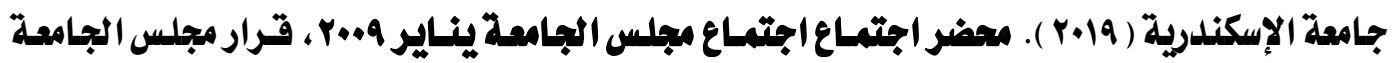

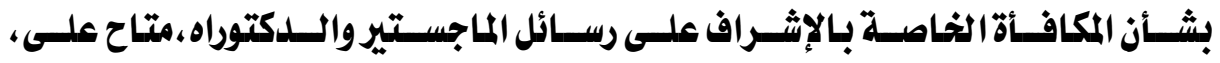

http://www.alexu.edu.eg/index.php/ar/2016-02-22-11-36-

, 29/3/2019.13/2744-university-council-record-january-2009

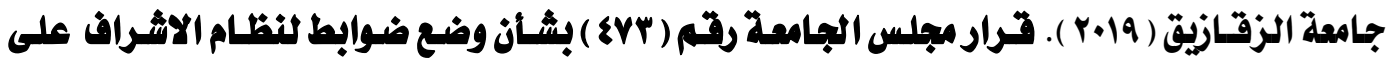
2

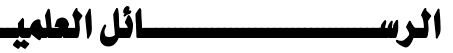

www.news.zu.edu.eg/ShowDetails/33711/11.,

$$
\text { 29/3/2019. }
$$

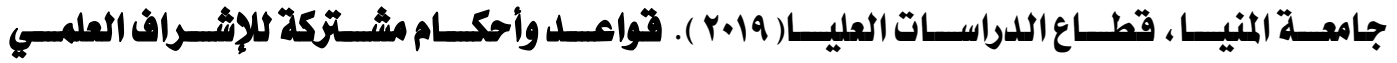
, 29/3/2019.https://www.minia.edu.eg/

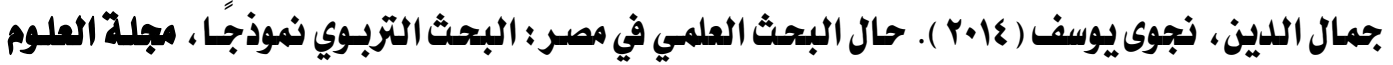
التزبوية، معهد الدراسات التربوية ( كلية الدراسات العليا للتربية حاليًا )، جامعة القاهرة،

$$
\text { r r (飞) )، الجزء الثاني، ( افتتاحية العلد ). }
$$

جمهورية مصر العربية، رئاسة مجلس الهوزراء، الهيئة القومية لضمان الجودة والاعتمـاد( (r) ). دليل $\bullet \cdot 1$

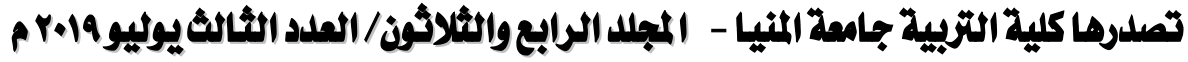
gamel_abdo59@yahoo.com

http://ms.minia.edu.eg/edu/journal.aspx 
اعتماد كليات معاهد التمليم العالي، ، ميار اللدراسات العليا، الإصلار الثالث، القاهرة، ص ص וצ-

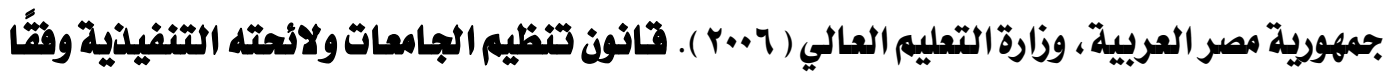
لآخر التعديلات، ط ( Y ) المعدلة، القاهرة: الهيئة العامة لشئوز المطابع الأميريـة، المواد

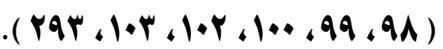

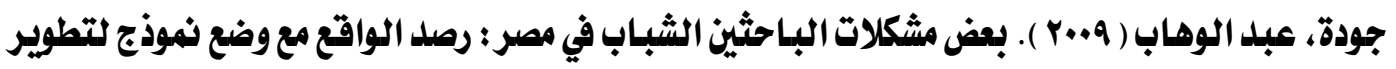
مهارات التفكير العلمي، أضواء على جودة التمليم الجامعي، القاهرة: اللدار العالية للنشر

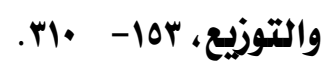

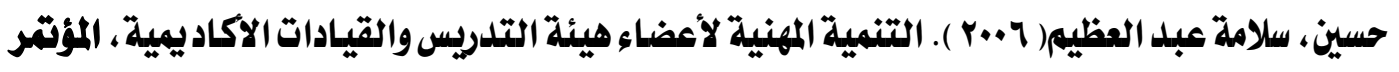

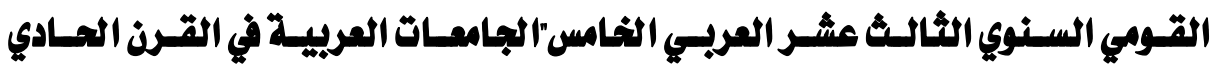

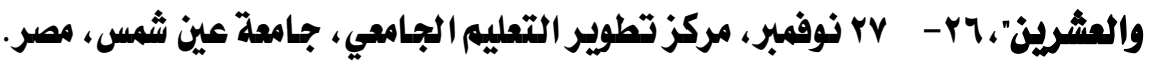

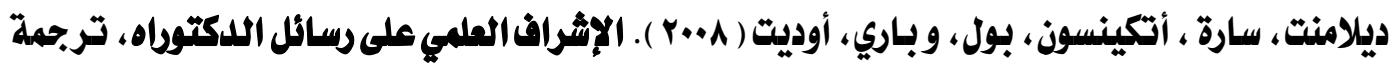
خالد العامري، القاهرة : دار الفاروق للنشر والتوزيع.

رجب، مصطفى، وطه ، حسين ( 1•+r). مناهج البجث التربوي بين النقد والتجليل، كفر الشيخ : دار العلم

$$
\text { والإيمان للنشر والتوزيع. }
$$

رزينك، ديفيد ب. ( 0.+r ). أخلاقيات العملم ملخل، ترجمة عبد النور عبد المنعم، سلسلة عالم المعرفة،

$$
\text { الكويت : المجلس الوطني للثقافة والفنوز والآداب. }
$$

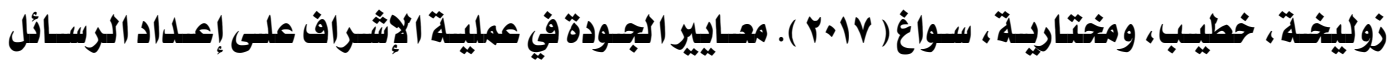

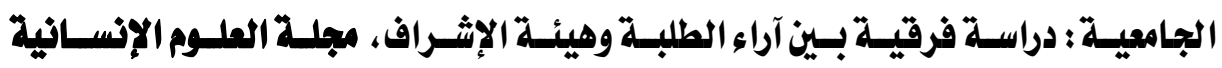
والاجتماعيـة ، كليـة العلـوم الإنسـانية والاجتماعيـة، جامعـة قاصـلي مربـاح، ورقلـة،

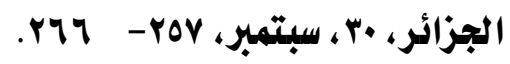

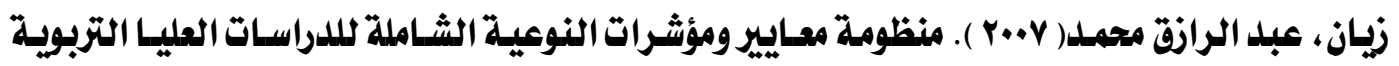
بالجامعات المصرية والعربية ومعوقات الوفاء بها دراسة تحليلية، المؤثقر القومي السنوي $0 . r$

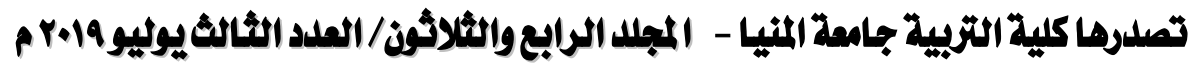
gamel_abdo59@yahoo.com http://ms.minia.edu.eg/edu/journal.aspx 


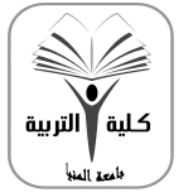

\author{
مجالة البجث في التزبية ومام النفس \\ كايلة التزبية - جامعة المثيا
}

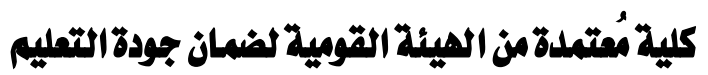

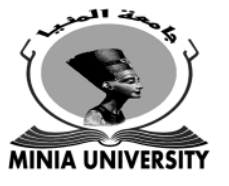

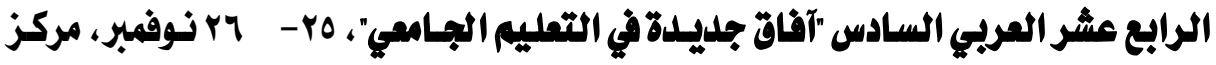

$$
\text { تطوير التعليه، جامعة عين شمس، مصر. }
$$

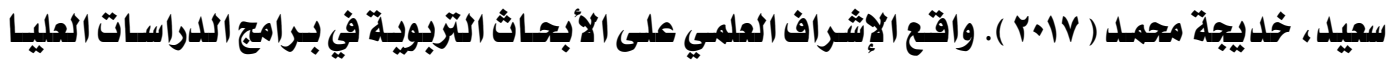
بجامعة أم القرى بمكة المكرمة من وجهة نظـر الباحثات في ضوي تخصصهز ، مجلة كلية

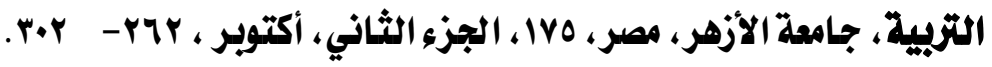

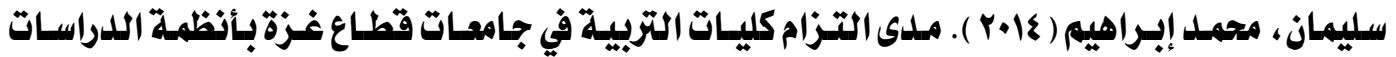

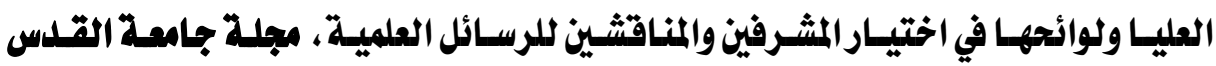

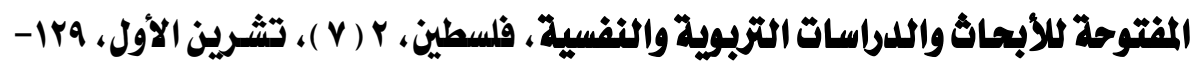
.IVY

شطناوي، نواف موسى ( †.r ). المشكلات الإدارية التي يواجهها طلاب وطالبات الدراسات العليا في جامعة اليرموك في مجال الإشراف على رسائلهم الجامعية، مجلة جامعة أم القرى للعلوم التزبوية والاجتمامية والإنسانية، جامعة أم القرى، السعودية، شا (ץ )، يوليو،

$$
. \varepsilon+1-r v \cdot
$$

عبـد الحليم، حنـان رزق ( ع.+r ).واقع معوقـات البحث التربـوي لطلاب الدراسـات العليـا بكليـة التربيـة بـالمنصورة ( دراسة ميدانية )، مجلة كلية التزبية، جامعة المنصورة، 00، الجزيء الأول، مـايو،

$$
\text { .AT }-10
$$

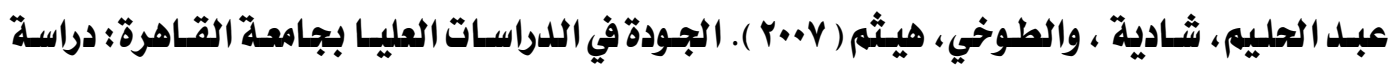

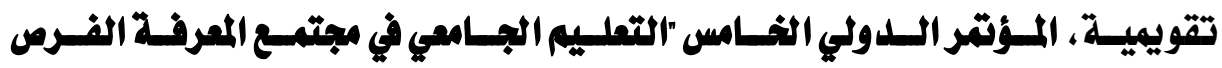

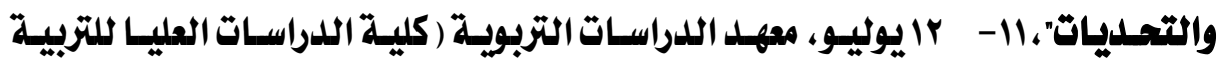
حاليًا )، جمامعة القاهرة، مصر.

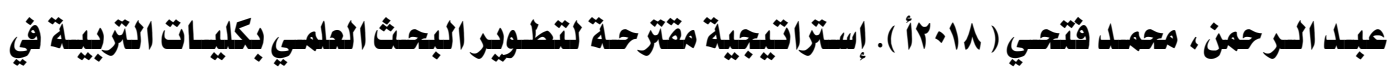
جههورية مصر العربية، رسالة دكتوراه غير منشورة، كلية التربية، جامعة المنيا. عبد الرحمن، محمد فتحي ( 1) مب ب ). الإثراف العلمي على رسائل الماجستير والدكتوراه بكليـات التربية ؛ $0 . r$

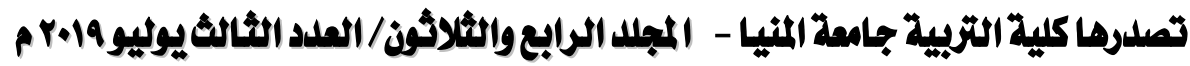
gamel_abdo59@yahoo.com

http://ms.minia.edu.eg/edu/journal.aspx 


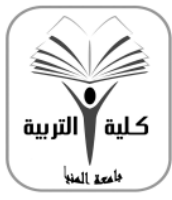

\author{
مجالة البجث في التزبية ومام الثفس \\ كايلة التزبية - جامعة المياتيا \\ كايلة مُتملمدة من الميئة القومية لضمان جودة التمليم
}

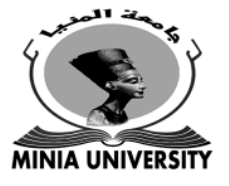

واقعه ومقترحات تطويره، "ورقة بحثية نظرية" نُشرت كمتطلب لمناقشة الدكتوراه للباحث،

مجلة البجثَ في التزبية وعلم النفسل، كلية التربية، جامعة المنيـا، سب( ( )، الجزي الأول،

$$
\text { يناير، ب. }
$$

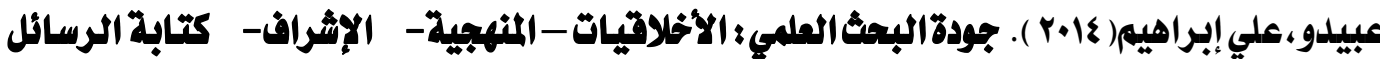
والبحوث العلمي، الإسكندرية : دار الوفاء للدنيا الطباعة والنشر.

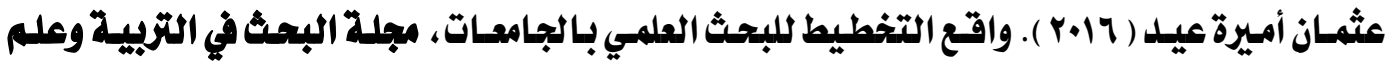

النفس، كالية التربية، جامعة المنيا، وج( (1)، الجزء الثالث، إبريل، هو- 79.

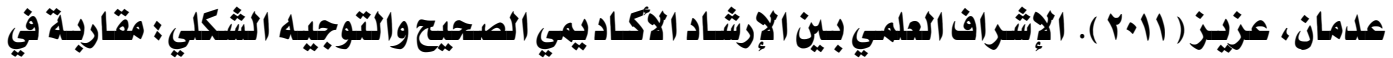
أصول منهجيـة التحصيل المعرفي، ملتقى صنامة البحث الملمي، الشبكة الفقهية، متحاح

http://www.feqhweb.com/vb/t10850.html\#ixzz523bH

$$
\text { ,10/12/2018.eNvO }
$$

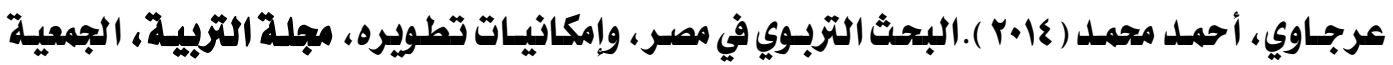
المصرية للتربية المقارنة والإدارة التعليمية، V| (9 )، أغسطس، بهץ- ro0.

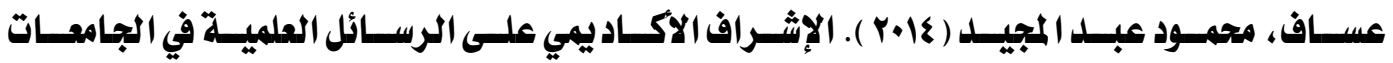

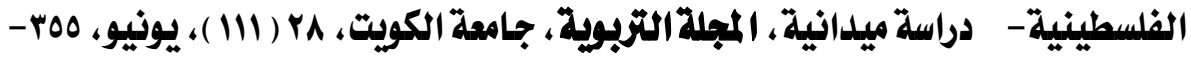

$$
.8 \cdot 7
$$

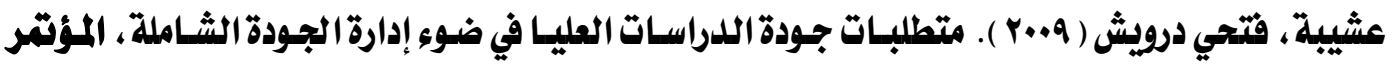
الملمي" توسين جودة برامج الدراسات المليا في مؤسسات التمليم العالي "مواجهة التحلديات

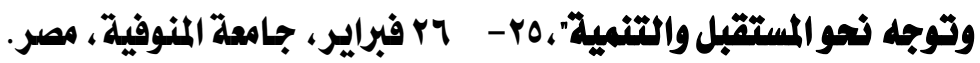

عطا، إبراهيم محمد ( 1991 ). الإشراف والتوجيه العلمي، القاهرة: مكتبة النهضة العربية. عفيفي، صلديق محمد( ع.•r ). أخلاق المهنة عند أستاذ الجامعة، القاهرة: وكالة الأهرام للتوزبع والنشر. $0 . \varepsilon$

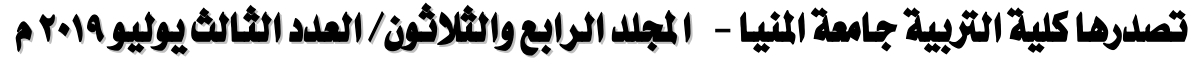
gamel_abdo59@yahoo.com

http://ms.minia.edu.eg/edu/journal.aspx 


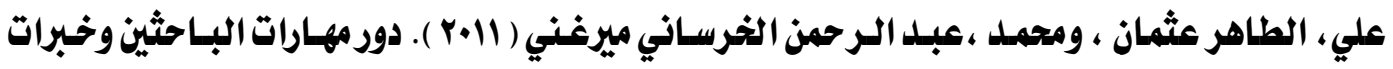
المشرفين في إعداد الرسائل الجامعية"، الماتققى العلمي الأول "خجويلد الرسـائل والأطروحسات

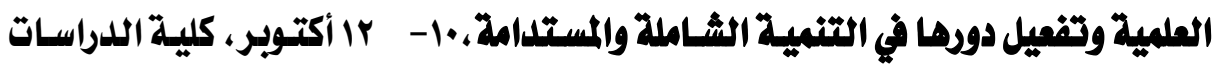
العليا، جامعة نايف العربية للعلوم الأمنية، الرياض، السعودية. عمار، إيعان حمدي ( 10 ( ). تنمية مهارات البحث التربوي لطلبة الدراسات العليا بكليات التربية في مصر في ضوء خبرات بعض السدول، المجلة التزبويـة، كلية التربيـة، جامعة سوهاج، ال، يوليو، rra - rir

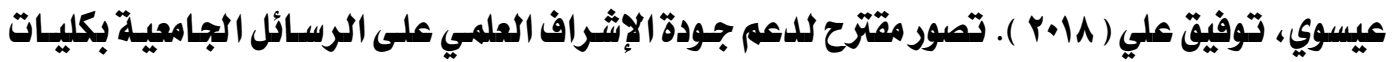

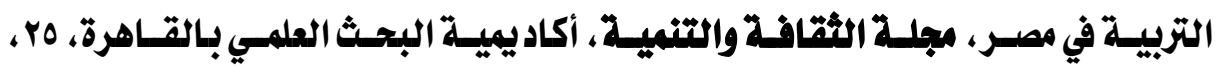

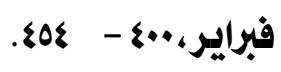

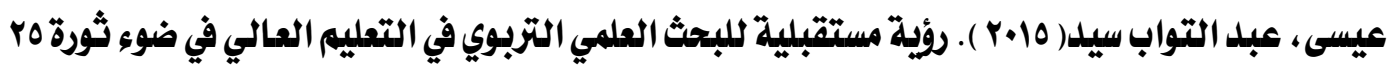
يناير في مصر، رسالة دكتوراه فير منشورة، معهد الدراسات التربوية ( كلية الدراسات العليا

$$
\text { للتربية حاليًا )، جامعة القاهرة. }
$$

غنايم، مهني ( r r ) ). توجهات البحث التزبوي في مصر رؤية الواقع واستشراف المستقبل، الندوة الملمية الأولي لقسم أصول التزبية "حال البحث التزبوي في مصر"، و ديسمبر، كلية التربية، جامعة الززقازيقة.

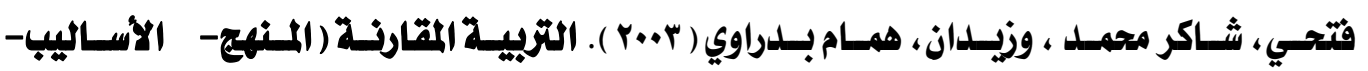
التطبيقات )، القاهرة؛ مجموعة النيل العربية.

مجمع اللفة العربية ( م+• ). المعجم الوجيز، طبعة خاصة بـوزارة التربية والتعليم، القـاهرة : الهيئة العامة لشئون المطابع الأميرية. محمل خالد فرج ( r.10) استقصاء آراء أعضاء هيئة التدريس في كلية التربية جامعة بنها حول بعض مقترحات لتطوير الإثراف العلمي بكليـات التربية في الجامعات المصرية، مجلةكايلة

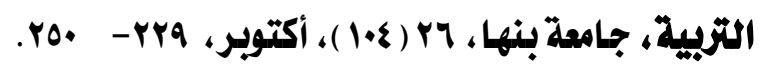
0.0

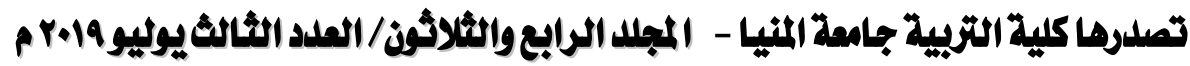
gamel_abdo59@yahoo.com http://ms.minia.edu.eg/edu/journal.aspx 


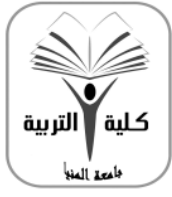

\author{
مجالة البجث في التزبية ومام النفس \\ كايلة التزبية - جامعة المياتيا \\ كلية مُقتملةمن الميئة القومية لضمان جودة التمليم
}

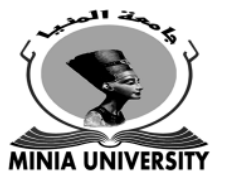

محمل، جمال مصطفى ( ع.+r ). دراسة تقو يمية للدور المشرف على الرسائل العلميـة بكليـات التربية بمصر في ضوي الكفايات اللازمة، رسالة دكتوراه غير منشُورة، كلية التربية، جامعة الأزهر ، مصر.

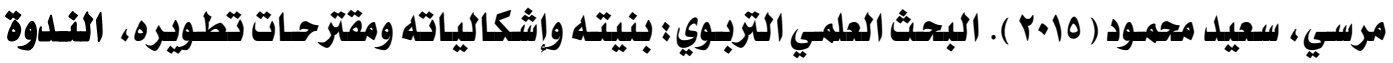
الملمية الأولي لقسم أصول التربية "حال البحث التربوي في مصر"، ب ديسمبر، كلية التربية،

جامعة الزقتازيق.

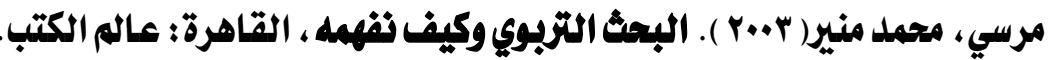

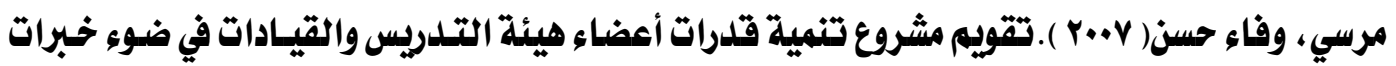

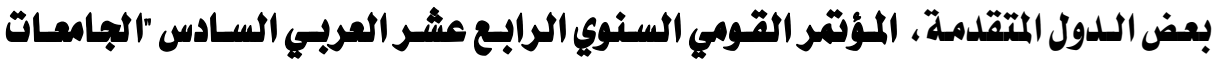

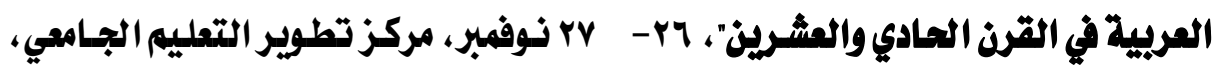

$$
\text { جامعة عين شمس، مصر. }
$$

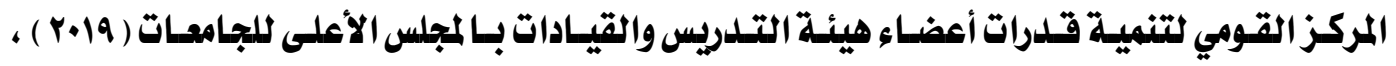
البرامج التدريبية لمجال البحث العلمي، 20/12/2018.http://www.ncfld.org ,

مصطفى، علي خليل، وسالم، محمود عوض الله ( 1991 ). الإثـراف على الرسسائل العلمية ودوره في فاعلية البحث العلمي ( دراسة نظرية )، مجالة كاية التزبية ببنها، جامعة الزقازيق، إبريل، ^•r-

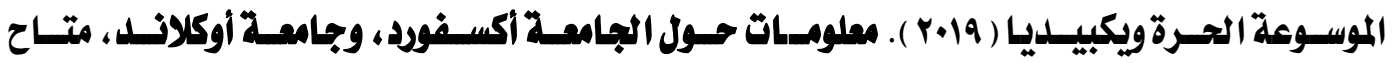
على:.https://ar.wikipedia.org/wiki, 22/1/2019

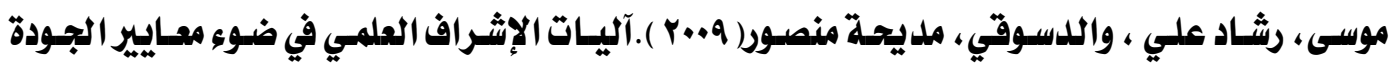

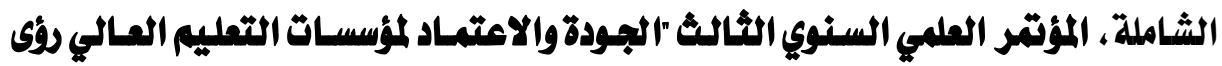

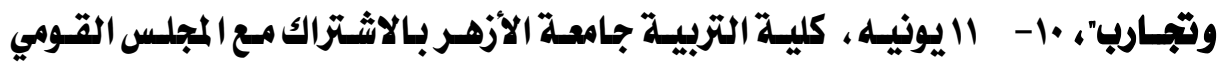
للريـاضة بجمهورية مصر العربية. نصر، محمد علي ( Y +. ) ). واقع البحث العلمي بـالجامعات العربية واتجاهـات ورؤى للتطوير والتحليث"،

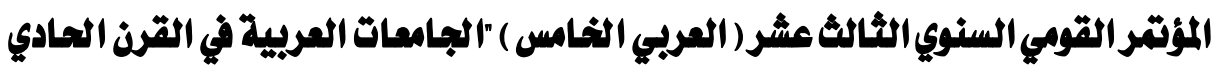

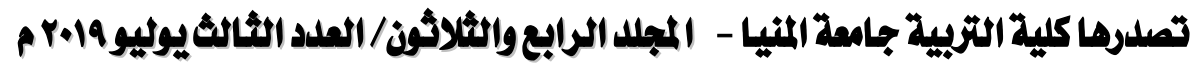
gamel_abdo59@yahoo.com

http://ms.minia.edu.eg/edu/journal.aspx 


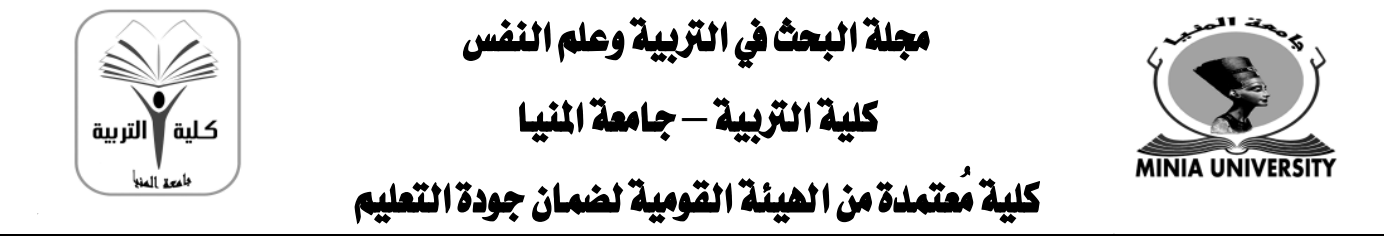

والعشرين : الواقع والرؤى"، جr - Y نوفهبر، مركز تطوير التعليم الجامعي، جامعة عين

شمس، مصر.

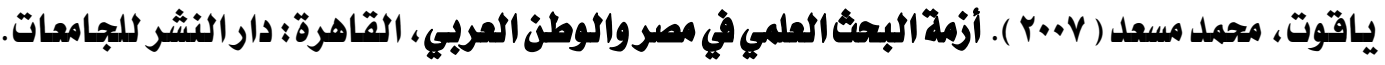

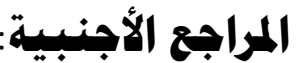

Abdallah,F., Hillerich,K., Romero,V., Topp,E.A., and Wnuk,K. (2010).Supervision of a Master's Thesis:Analysis and Guidelines, LTHs 6:e Pedagogiska Inspirationskonferens, 15, december, 1-3.

Abiddin.N., Hassan, A., Ahmad, A. (2009). Research Student Supervision: An Approach to Good Supervisory Practice, The Open Education Journal, 2, 11-16.

Ali, P., Watson, R., \& Dhingra, K. (2016). Postgraduate research students' and their supervisors' attitudes towards Supervision. International Journal of Doctoral Studies, 11, 227-241.

Ana V. Baptista, (2011). Challenges to doctoral research and supervision quality: A theoretical approach, Procedia Social and Behavioral Sciences, 15, 3576-3581.

Armstrong, S. (2005). The impact of Supervision Conntive Stiles on The quality of Research Supervision in Management Education British, Journal of Education Psychology, 74, 566-610.

Auckland University (2019). The University Mission and Message\& Values, Available at https://www.auckland.ac.nz/en/aboutus/about-the-university/the-university/ Mission and Values Imessage-from-the-vice-chancellor.html, 12/1/2019.

Auckland University, Academic disputes and complaints(2019) policiesand-guidelines, Available https://www.auckland.ac.nz/en/students/forms-policies-andguidelines/student-policies-and-guidelines/academic-disputesand-complaints.html, 6- 4- 2019.

Auckland University, School Graduate Studies (2014). Senate Guidelines on Thesis Supervision, Approved by Board of Graduate Studies February 2014 and Senate April 2014Last updated 17.02.14, Available at https://cdn.auckland.ac.nz/assets/central/for/currentstudents/postgraduate-students/documents/policies-guidelinesforms/senate-guidelines-thesis-supervision.pdf, 6- 4- 2019.

Calama, A, (2007A).Research Higher Degree Supervision in Philippines: Exploring Possibites for Research, Presented at the $0 . V$

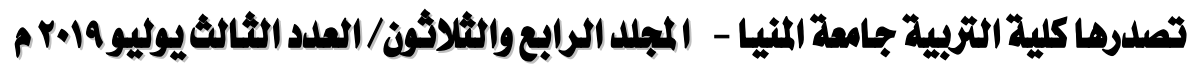
gamel_abdo59@yahoo.com

http://ms.minia.edu.eg/edu/journal.aspx 


\section{مجلة البعث في التزبية وعلم النفس \\ كالية التربية - جامعة المنيا}

كالية مُعتمدة من الهيئة القومية لشمان جودة التعليم

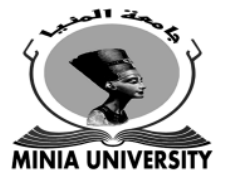

International Conference on Research in Higher Education Institution, 24- 27 October , Cebu City, Philippines.

Calama, A, (2007b).Postgraduate Supervision in The Philippines: Setting The Research Agenda, The Asia- Pacific Education Higher Researcher, 16(1), 91- 100.

Carter, G. (1993). Dictionary of Education, 3rd Ed, McGraw Hill.

Carton, J. (2018). Research Supervisor Support and Development Review of Policy, Practices and Procedures in five U21 Partner Universities, Project kindly supported by Universitas 21 and UCD International, Graduate Education Development, UCD Graduate Studies.

Cornér, S., Löfström, E., \& Pyhältö, K. (2017). The Relationships between doctoral students' perceptions of supervision and burnout. International Journal of Doctoral Studies, 12, 91106.

Dimitrova, R. (2016). Ingredients of Good PHD Supervision - Evidence form A Student ..Survey at Stockholm University, UTBILDNING \& LÄRANDE, 10 (1), 40- 52.

Fernando, D. (2004). The Relationship of Supervisory Styles to Satisfaction and Self- efficacy of Master's level Counseling Student, International Dissertation Abstracts, 64, 4369.

Grant, K., Hackney, R., \& Edgar, D. (2014). Postgraduate research supervision: An 'agreed' con-ceptual view of good practice through derived metaphors, International Journal of Doctoral Studies, 9, 43-60.

Gurr, G. (2007). Negotiating The "Rackety Bridge" dynamic Model for Aligning Supervisory Styles with Research Student", development Higher Education and Development, 20, 8190.

Kiley, M. (2011).Developments in Research Supervisor Training, Studies in Higher Education, 36 (5), 585-599.

Lee, A. M. (2007). Developing effective supervisors: Concepts of research supervision, South African Journal of Higher Education, SAJHE, 21(4), 680-693.

Lessing, A.C., Schulze, S. (2003). Lecturers' experience of postgraduate supervision in a distance education context, SAJHE/SATHO, $17(2), 159-168$.

Lindgreen, A., Palmer, R., Vanhamme, J., and Beverland, M.B. (2003). Finding and choosing a supervisor", The Marketing Review, 3(2), 147-166. 0.1 


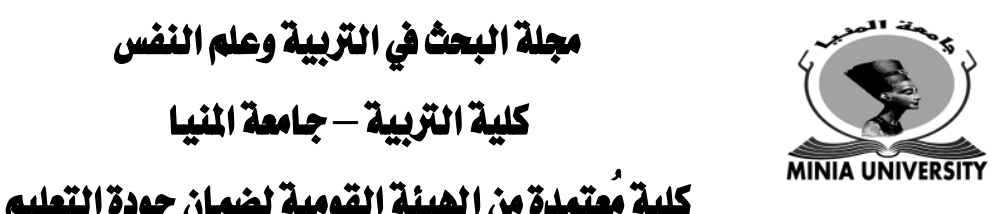

Masek, A. (2017). Establishing supervisor-students' relationships through mutual expectation: A study from supervisors' point of view, International Research and Innovation Summit (IRIS2017), IOP Publishing, 2-11.

Ministry of Education in England. The University of Oxford (2019). Education Committee, Available at https://www.admin.ox.ac.uk/edc/6/1/2019.

National Health and Medical Research Council, the Australian Research Council and Universities Australia (2018). Australian Code for the Responsible Conduct of Research, Available at, https://nhmrc.gov.au/about-us/publications/australian-coderesponsible-conduct-research-2018, 15/1/2019.

Nulty, D., Kiley ,M., \& Meyer ,N.(2008). Promoting and recognizing excellence in the supervision of research students: an evidence-based framework, Assessment \& Evaluation in Higher Education, 6, October, 1-14.

Official university website, Oxford, New South Wales, Auckland, (2019) Supervision of Codes Practice and Guidelines, Supervision Policy and Procedures, Available at https://www.admin.ox.ac.uk/edc, $h$ ttps://www.unsw.edu.au, https://www.auckland.ac.nz, 17/1/2019.

Oxford University Policies and Guidance (2019) Policy on Research Degrees, Section:5, responsibilities of the student, Available at

https://www.admin.ox.ac.uk/edc/policiesandguidance/policyo nresearchdegrees/section5responsibilitiesofthestudent/\#d.en.1 36720, 22/2/2019.

Oxford University, GSS ( 2019). Graduate Supervision System GSS,Available at https://www.admin.ox.ac.uk/edc, 17/1/2019.

Oxford University, Humanities Division ( 2018). Code of Practice on Supervision of Graduate Research Students, p.2., Available at https://www.admin.ox.ac.uk/edc, 17/1/2019.

Oxford University, Medical Sciences Board (2014). Code of practice on supervision, p.2, Available at https://www.admin.ox.ac.uk/edc, 17/1/2019.

Oxford University, Social Sciences Division (2018). Code of practice on supervision, p.3, Available at https://www.admin.ox.ac.uk/edc, 17/1/2019.

Oxford University, Student Systems (2019). Student Systems Supervision, Available at http://www.admin.ox.ac.uk/studentsystems/gsr/6/1/2019. 0.9

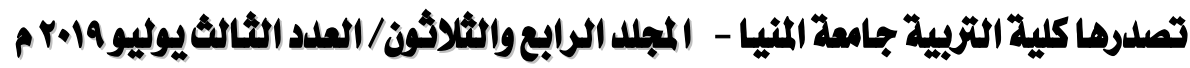

gamel_abdo59@yahoo.com

http://ms.minia.edu.eg/edu/journal.aspx 


\section{مجلة البعث في التزبية وعلم النفس \\ كالية التربية - جامعة المنيا \\ كالية مُمتمدة من الهيئة القوميلا لضمان جودة التمليم

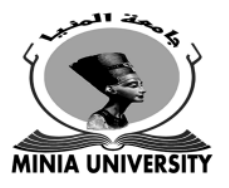

Peelo, M. (n.d). Supervisory Teams and Joint Supervision, Available at http:// WWW. Lancs.ac. uk/ celt/ celtweb/files/ jointsupervision08.pdf, 26/7/2016.

Phang, F., Sarmin, N., Zamri, S., \& Salim, N. (2014). Postgraduate Supervision: Supervisors versus Students, International Conference on Teaching and Learning in Computing and Engineering.

Pro-Vice-Chancellor, Research Training (2016). Supervision Policy, Current version: 4, 15 June 2016 to date, P.1, Available at https://www.gs.unsw.edu.au/policy/documents/hd.pdf, $10 / 1 / 2019$.

Pro-Vice-Chancellor, Research Training (2018). Higher Degree Research Supervision Procedure, Version: 1, Effective 18 September, 2018, pp. 1 - 6.

Pro-Vice-Chancellor, Research Training (2019). Higher Degree Research Supervision Guidelines, Version: 2 ,Effective, September, 2018, pp $2-9$, Available . at https://www.gs.unsw.edu.au/policy/documents/hdrsupervision guide.pdf, 25- 2- 2019.

Rath, J. (2009). Research Supervision in Non-University Higher Education Institutions: New Zealand Supervisors' Acquisition of Skills, Paper presented at the British Educational Research Association Annual Conference, 2-5 September ,University of Manchester.

Severinsson, E. (2012). Research supervision: supervisory style, research-related tasks, importance and quality - part 1, Journal of Nursing Management, 20, 215-223.

Severinsson, E. (2015). Rights and responsibilities in research supervision, Nursing and Health Sciences, 17, 195-200.

Skeritte, C., Roch, A. (2004). A constructivist Model for Evaluating Postgraduate Supervision: A Case Study, Quality Assurance in Education, 12, 82-93.

Swarts, A. (2017). Nurturing and Inspiring Across Supervisory Styles and Practices, African SUN MeDIA, Strengthening Postgraduate Supervision. Stellenbosch: SUN PRESS, AFRICAN SUN MeDIA, 229- 239.

The University of Auckland, "CLeaR"(2018): Training Supervisors, Available at https://www.auckland.ac.nz/en/staff/learningand-teaching/clear.html, 22/1/2019.

The University of Auckland, Department of Statistics (2019). Supervisors and supervision, Available at 01 . 


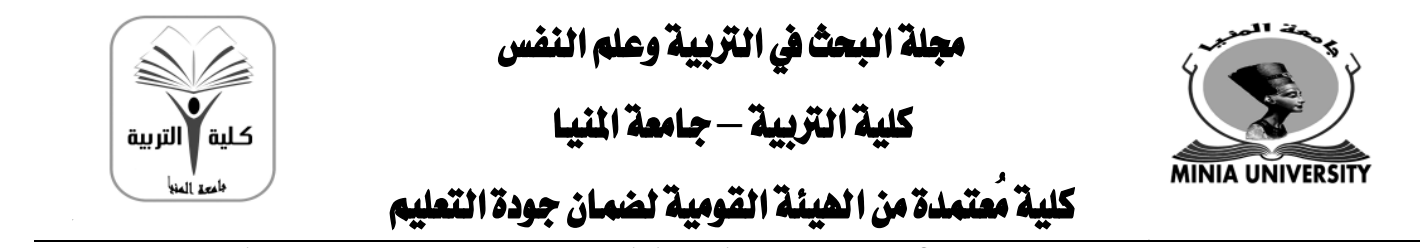

https://www.stat.auckland.ac.nz/en/for/currentstudents/information-for-postgraduate-students/postgraduatestudents-faq/supervisors-and-supervision.html,6- 4- 20191, 64- 2019.

The University of Auckland, Graduate Centre (2016). Doctoral Supervision Policy and Procedures (2016 PhD Statute), Board of Graduate Studies, Available at https://www.auckland.ac.nz/en/about/the-university/howuniversity-works/policy-and-administration/teaching-andlearning/postgraduate-research/supervision/thesissupervision1.html, 23/3/2019.

The University of Auckland, Graduate Centre, (2016). Code of Practice: Postgraduate Research Degrees, pp1- 15, Available at https://www.auckland.ac.nz, 25/1/2019.

The University of Auckland, Graduate Centre, (2018). Postgraduate Supervision Guidelines, (2018 PhD Statute), Board of Graduate Studies, p.3. Available at https://www.auckland.ac.nz/en/about/the-university/howuniversity-works/policy-and-administration/teaching-andlearning/postgraduate-research/supervision/postgraduatesupervision-guidelines1.html, 15/2/2019.

The University of New South Wales (2019). About UNSW,_Available at https://www.unsw.edu.au/about-us, 22/1/2019.

The University of Oxford (2019). Facts and Figures, student-numbers, Available at https://www.ox.ac.uk/about/facts-andfigures/student-numbers?wssl=1, 25/1/2019.

The University of Oxford (2019). Policies and guidance, Policy on Research Degrees, section:4, supervision, Available at https://www.admin.ox.ac.uk/edc/policiesandguidance/policyo nresearchdegrees/section:4 supervision/\#wrapper,23/1/2019.

Tian, W., Singhasiri, W. (2016). Learning opportunities in $\mathrm{PhD}$ supervisory talks: A social constructionist perspective, Issues in Educational Research, 26(4), 653- 672.

Universities Rights and responsibilities in research supervision, The National Tertiary Education Union , The Council of Australian Postgraduate Associations and The Australian Council of Graduate Research (2016). Principles for respectful supervisory relationships.

University of Oxford, Oxford Learning Institute. (2019). The Research Supervision website: An introduction for research students, Available at $\bullet 11$ 

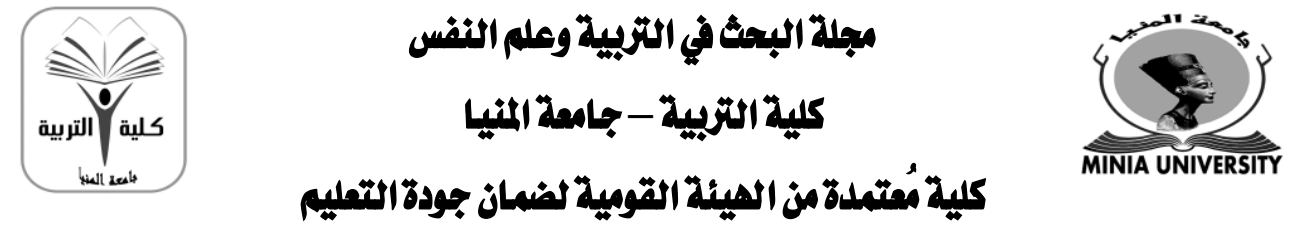

www.learning.ox.ac.uk/.../wwwadminoxacuk/.../oxfordlearnin ginstit... Oxford Learning Institute University of Oxford, $22 / 2 / 2019$.

University of Oxford, Research Training (2019). Research Training, Available athttps://sharepoint.nexus.ox.ac.uk/sites/humanities/ research training/training/SitePages/Home.aspx, 22/2/2019.

UNSW (2019). About the University of New South Wales, Available at https://www.hotcourses.ae/study/australia/school-collegeuniversity/university-of-new-south-walesunsw/72233/international.html, 23/1/2019.

UNSW, Conflict of Interest Policy (2017). Conflict of Interest Policy, Current version (1.3), 15 August 2017 to date, Available at https://www.gs.unsw.edu.au/policy/conflictinterestpolicy.html , 27/2/2019.

UNSW, policy thesis exam (2019). Policy thesis exam, p.6 Available at https://www.gs.unsw.edu.au/policy/documents/thesisexampro c.pdf, 26- 2- 2019.

Van Rensburg GH, Mayers, P. \& Roets L. (2016). Supervision of postgraduate Students in Higher Education, Trends in Nursing, 3(1), 1-14.

World University Rankings The Times Higher Education (2019). The Times Higher Education, Available at https://www.timeshighereducation.com/world-universityrankings/2016,2017, 2018, 2019/worldranking\#!/page/0/length/25/sort_by/rank/sort_order/asc/cols/st ats, 26/1/2019.

World University Rankings, (2018). Shanghai Ranking, Available at http://Www.shangha iranking.com/ARWU . 2014, 2015, 2016,2017, 2018.html, 24/1/2019.

World University Rankings, QS (2019). "QS" Ranking, Available at https://www.topuniversities.com/university-rankings/worlduniversity-rankings/2016, 2017, 2018, 2019, 18/1/2019.

Zaho, F. (2002).Transforming Quality in Research Supervision: A Knowledge Management Approach", Paper Presented at the 7th Quality in Higher Education International Seminar: Transforming Quality, RMITm Melbourne, Available at http:// WWW. Quality research International/ Com/ tq/papers/ zhaopaper. doc., 26/7/2016. 